MaIRA YURiko Rocha MiUra

\title{
Os cartéis de exportação na ordem jurídica brasileira Uma visão de Direito Comercial
}

Dissertação apresentada à Faculdade de Direito da Universidade de São Paulo, para obtenção do título de Mestre em Direito Comercial, sob orientação da Professora TItUlar PAula A. Forgioni.

Faculdade de Direito da Universidade de São Paulo São Paulo 
Para o meu Avô Laércio, para minha Avó Regina, para minha Mãe Sônia Regina, para minha Julie e para meu Francisco. 
Índice

1. INTRODUÇÃO

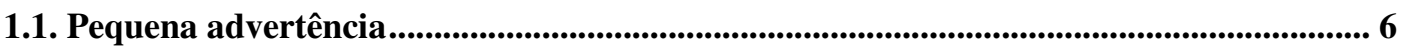

1.2. A divisão dos Capítulos ............................................................................................................................ 6

1.3. Justificativa e importância do tema ................................................................................................... 8

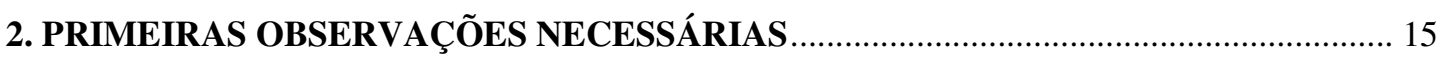

2.1. A Escola Estruturalista de Harvard............................................................................. 19

2.2. A Escola de Chicago e a proteção à eficiência alocativa................................................... 23

2.3. Observações sobre proteção aos consumidores............................................................................ 32

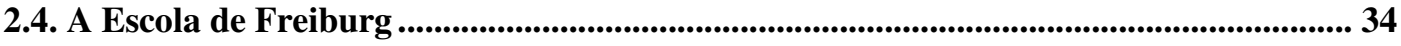

2.5. Outras formas de entendimento da matéria............................................................................. 36

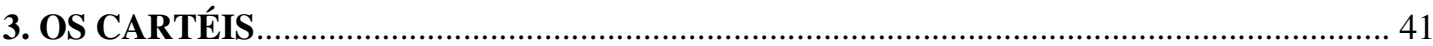

3.1. Justificativas para a sua existência..................................................................................................... 46

3.2. A problemática ao longo dos séculos .................................................................................................... 51

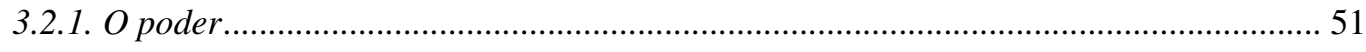

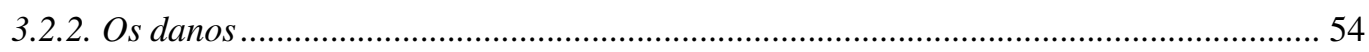

3.3. Necessária distinção entre os acordos entre concorrentes ............................................... 56

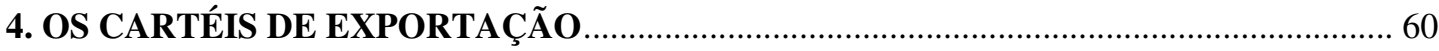

4.1. Classificações e formas de isenção............................................................................................. 63

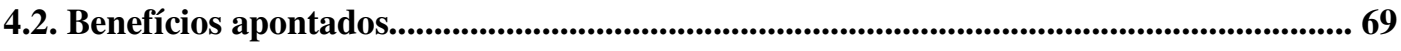

4.2.1. Diminuição dos custos de exportação e estímulo à competitividade ............................. 69

4.2.2. Aumento do poder de barganha .................................................................................. 73

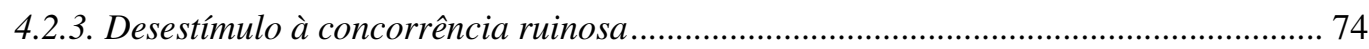

4.2.4. Nascimento de um novo competidor no mercado externo ............................................. 76

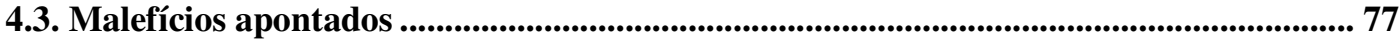

4.3.1. Utilização do cartel de exportação em atividades outras que não a exportação .......... 78

4.3.2. Desincentivo para a construção de uma "política internacional da concorrência" .... 80

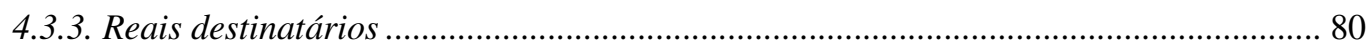

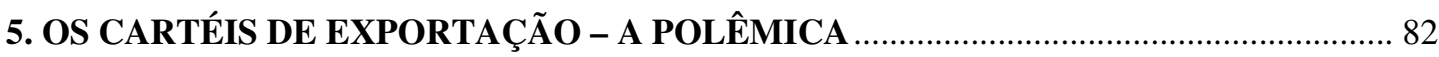

5.1. Motivação da polêmica.................................................................................................................................... 82

5.2. Benefícios da política comum.................................................................................................................... 89 
5.3. Dificuldades de uma política comum

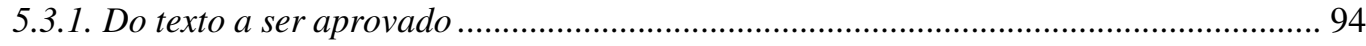

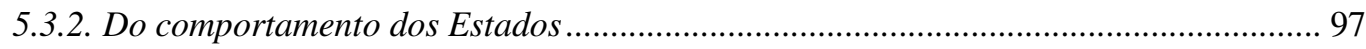

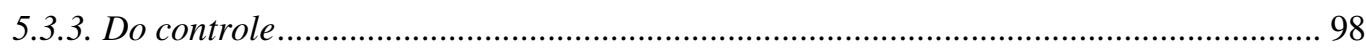

6. OS CARTÉIS DE EXPORTAÇÃO - A POLÊMICA - SEGUE ………….......................... 101

6.1. Cartéis de exportação são realmente um problema?............................................................... 101

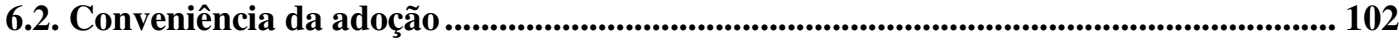

6.3. Uma conclusão preliminar .............................................................................................................. 114

6.4. Contraponto: a discussão ocorre há muito no Brasil ......................................................... 116

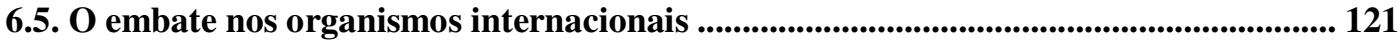

6.6. Experiência internacional na aplicação dos objetivos antitruste e na utilização dos cartéis de exportação ................................................................................................................................... 124

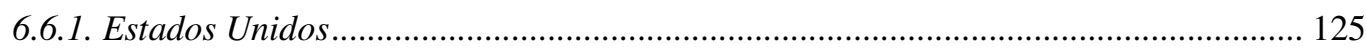

6.6.1.1. O caso específico dos cartéis de exportação ..................................................... 128

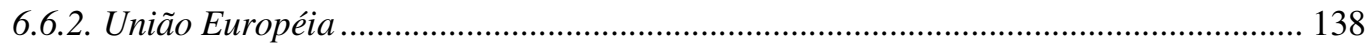

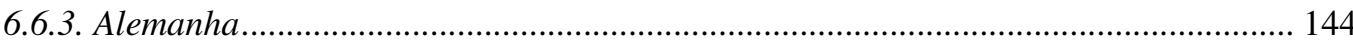

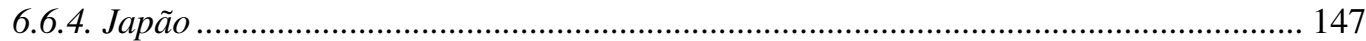

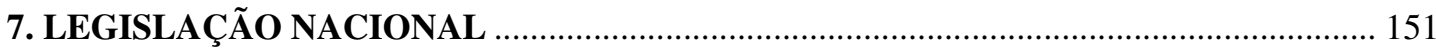

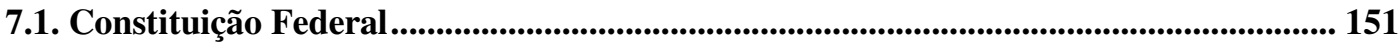

7.2. Os objetivos da República Federativa do Brasil ............................................................. 156

7.3. Os cartéis de exportação e o artigo 170 da Constituição Federal .................................... 159

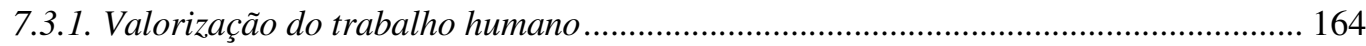

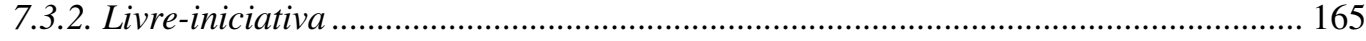

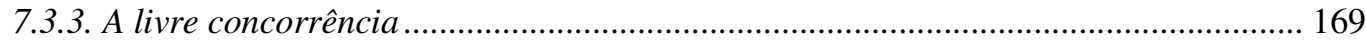

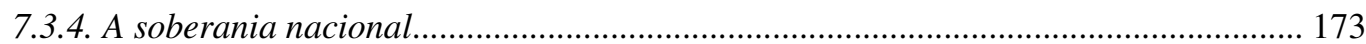

7.3.5. A redução das desigualdades regionais e sociais, a busca pelo pleno emprego e o tratamento favorecido para as empresas de pequeno porte constituídas sob as leis brasileiras

7.4. O artigo 219 da Constituiçã̃o ............................................................................................................... 178

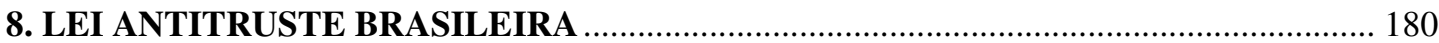

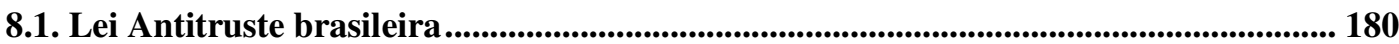

8.2. Âmbito da lei Antitruste e extraterritorialidade......................................................................... 182

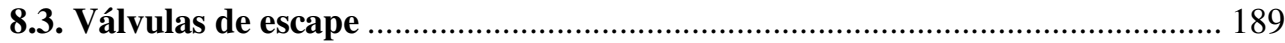


8.4. A disciplina dos cartéis ............................................................................................................... 199

8.5. A experiência brasileira.............................................................................................................. 205

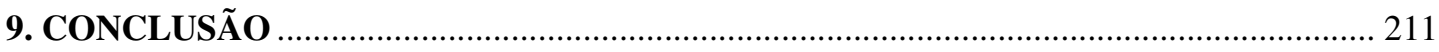

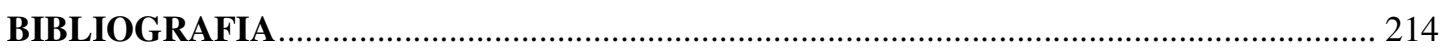

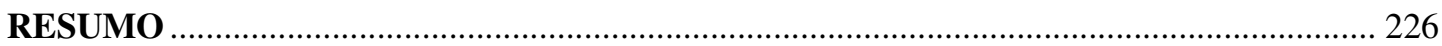

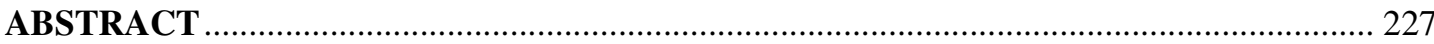




\section{INTRODUÇÃO}

\subsection{Pequena advertência}

Este trabalho é um estudo sobre a possibilidade de utilização dos cartéis de exportação na ordem jurídica brasileira ${ }^{1}$. Esse é o seu tema.

Tendo em vista a necessidade de delimitação do campo de pesquisa para que o assunto pudesse ser minimamente aprofundado, optou-se por abarcar na análise unicamente as discussões trazidas pelo direito constitucional e pelo direito concorrencial ${ }^{2}$. O corte é necessário para fins de metodológicos, mas acaba por não privilegiar outras áreas do conhecimento, como o direito internacional e a ciência da economia, essenciais para a completa compreensão dos cartéis de exportação.

Outro ponto a se clarear é que inúmeros assuntos polêmicos serão tratados ao longo do trabalho, com ênfase na relação conflituosa entre os Estados na adoção de políticas de cunho neoliberal pelos países. Esses temas, afirme-se desde logo, serão tratados de maneira passageira e unicamente na medida em que puderem colaborar para a compreensão dos cartéis de exportação.

\subsection{A divisão dos Capítulos}

A divisão dos capítulos foi elaborada de forma a tornar lógico o encadeamento dos assuntos, sua problematização e as conclusões a que chegamos.

O Capítulo 1 será introdutório e trará a justificativa para a escolha do tema desse trabalho. Iniciaremos com a da idéia de que os cartéis de exportação são instrumentos de fomento às exportações. A partir de então, demonstraremos a importância dessa atividade

\footnotetext{
1 As expressões "cartéis de exportação" e "associações para exportação" serão utilizadas indistintamente ao longo deste trabalho.

2 Os termos "direito antitruste" e "direito concorrencial" serão utilizados indistintamente.
} 
para os países, retratando a sua influência sobre os níveis de atividade interna e como ela pode contribuir para o desenvolvimento econômico.

No Capítulo 2 traremos uma importante discussão, necessária para o entendimento de qualquer questão relativa ao direito concorrencial: trata-se da identificação das Escolas teóricas que permeiam a sua aplicação. A despeito de parecer precipitada tal diferenciação no início do estudo, entendemos ser necessário que, desde logo, fiquem marcadas as influências que podem alterar a aplicação desse ramo do direito e o entendimento sobre os cartéis de exportação. Ao evidenciar essas características no segundo Capítulo, possibilitase também que uma visão crítica dos institutos seja desde logo estabelecida.

O Capitulo 3 trabalhará o conceito de cartel. A primeira parte será histórica e se aterá no poderio político e econômico que envolveu a formação das associações para exportação desde a antiguidade. Em seguida, estabeleceremos a importante distinção entre os cartéis tradicionais e os cartéis de exportação, demonstrando a necessidade de disciplina diferenciada para os últimos.

O Capítulo 4 iniciará a discussão sobre os cartéis de exportação, trazendo as classificações apresentadas pela doutrina, assim como considerações sobre os benefícios e malefícios advindos de sua utilização.

O Capítulo 5 abordará os conflitos existentes no âmbito internacional para adoção das associações para exportação. Nesse passo, verificaremos como a influência de elementos externos (ou seja, não condizentes com a política interna dos países) pode prejudicar a opção por utilizá-los. Observaremos como a alteração dos padrões de concorrência internacional foi responsável pelo recrudescimento da aplicação dos postulados ligados à economia neoclássica (ou, na terminologia de LUIZ CARLOS BRESSER-PEREIRA, da ortodoxia econômica), especialmente aqueles referentes à busca pelo livre comércio entre as nações. Mais ao final do Capítulo, desenvolveremos a idéia de que a busca pela harmonização das legislações concorrenciais do globo, (a adoção de uma "política internacional da concorrência"3) pode ser um reflexo do surgimento de novas potências comerciais. Fecharemos essa parte do estudo com o levantamento das

\footnotetext{
3 Trataremos genericamente qualquer proposta de padronização da legislação de concorrência como a
} "política internacional da concorrência". Mais detalhes sobre ela podem ser encontrados na nota 166. 
argumentações favoráveis à adoção de tal política e as dificuldades que seriam encontradas para tanto.

O Capítulo 6 será uma extensão do Capítulo anterior. Discutiremos a conveniência da adoção da política concorrencial comum, especialmente pelos países em desenvolvimento, além de verificarmos como ela pode afetar a utilização dos cartéis de exportação. Para o caso específico do Brasil, um breve retrospecto sobre as atividades da Comissão Econômica para a América Latina e Caribe - CEPAL nos ajudará a compreender como as questões relativas ao comércio internacional e ao subdesenvolvimento têm sido tratadas por nossos pensadores. Traremos, ainda, um breve estudo de direito comparado, evidenciando como outros ordenamentos lidam com a questão dos objetivos do direito concorrencial e como disciplinam os cartéis de exportação.

Os Capítulos 7 e 8 trarão o estudo do ordenamento jurídico brasileiro. Primeiramente nos ateremos à Constituição Federal e buscaremos inserir os cartéis de exportação na moldura por ela trazida, dando especial destaque para o artigo $3^{\circ}$ (objetivos fundamentais da República Federativa do Brasil) e para o artigo 170 (princípios gerais da atividade econômica). Passaremos, então, à análise da legislação infraconstitucional, com ênfase na legislação antitruste brasileira e os dispositivos relacionados aos acordos entre concorrentes.

O Capítulo 9 será dedicado às conclusões deste estudo.

\subsection{Justificativa e importância do tema}

Como verificaremos com mais vagar ao longo do Capítulo 4, os cartéis de exportação são uma forma de estímulo à atividade de exportação, visto que, por meio de sua utilização, as empresas podem se tornar mais competitivas no mercado internacional ${ }^{4}$. Essa melhoria é especialmente relevante nos dias atuais, em que o acirramento das disputas comerciais entre os países é evidente.

$4 \quad$ Nos termos deste trabalho "mercado" deve ser compreendido como o conjunto de instituições que permite que o intercâmbio entre agentes seja possível. Nesse sentido, a perspectiva de NATALINO IRTI, L'ordine giuridico del mercato, 3. ed., Roma, Laterza, 1998. 
É dentro dessa perspectiva - de meios capazes de fomentar a atividade de exportação - que devemos compreender a importância de uma séria discussão sobre a possibilidade de utilização das associações para exportação no ordenamento jurídico brasileiro.

A história nos relata que o incentivo às exportações não é novo. Por séculos, países se digladiaram e empregaram diversas políticas para elevar o seu volume (para uma breve ilustração, basta recordar as medidas tomadas ao longo do século XVIII pela Grã-Bretanha com relação ao comércio com Portugal, em especial, a assinatura do Tratado de Methuen). Nos dias atuais essas políticas também são comuns, com o desestímulo ao consumo dos produtos importados 5 . Certamente não se busca que os países apenas exportem seus produtos, não adquirindo bens produzidos em outros países, mas ao final, todos esperam obter um saldo positivo na balança comercial (diferença entre os níveis de exportação e de importação) $)^{6}$.

Mas qual seria o motivo da antiga preocupação?

Simplificando as sofisticadas teorias macroeconômicas, podemos vislumbrar que os déficits comerciais, resultantes de níveis de importação superiores aos de exportação, nada mais significam do que dívidas contraídas. Esses valores, contabilizados em moedas estrangeiras, certamente serão cobrados acrescidos de taxas de juros, o que pode trazer grande instabilidade financeira para o país devedor (a esse respeito, devemos nos lembrar da grave crise enfrentada na década de 1980 para o pagamento de suas obrigações externas, geralmente conhecida como a "crise da dívida").

Um outro aspecto importante sobre as exportações (e de grande relevância para se justificar a adoção dos cartéis de exportação) é a possibilidade de fomento à atividade

\footnotetext{
5 Os economistas referem-se a dois pontos essenciais para a determinação do nível de importações. O primeiro é o nível geral de demanda por bens e o segundo é a forma como se fixa a taxa de câmbio. "De que depende a quantidade das importações, Q? Basicamente, do nível geral da demanda interna: quanto mais alta for a demanda doméstica, mais alta será a demanda por todos os bens, tanto produzidos internamente quanto estrangeiros [...]. Contudo, Q também depende claramente da taxa real de câmbio: quanto mais alto é o preço dos bens internamente, mais baixa é a demanda relativa por bens estrangeiros e mais baixo o volume de importações" (OLIVIER BLANCHARD, Macroeconomia, 2. ed., Rio de Janeiro, Campus, 2001, p. 398).

6 Obviamente se reconhecem os benefícios advindos da participação no comércio internacional, uma vez que não é dado a nenhum país viver como se fosse uma ilha isolada. A participação nesse comércio é, inclusive, uma forma de permitir que os produtos brasileiros sejam colocados e consumidos no exterior, trazendo divisas para o Brasil.
} 
interna dos países. Imaginemos a seguinte situação: um conjunto de exportadores se une para comercializar um novo produto ${ }^{7}$. Sua colocação no mercado internacional é bem sucedida e, sendo assim, as empresas nacionais expandem suas atividades. Esse aumento da venda de produtos nacionais, certamente, não atingirá somente aquela empresa, mas se espraiará para outros setores, resultando em benefícios econômicos e sociais, como a contratação de novos funcionários, que, por sua vez, disporão de mais recursos financeiros para adquirir outros bens, o que estimulará a fabricação de outras mercadorias, em um efeito em cadeia que poderá impulsionar favoravelmente a economia.

Esses impulsos externos podem ser fatores importantes a colaborar com o desenvolvimento nacional que, como veremos no Capítulo 7, é um dos objetivos da República Federativa do Brasil. Com efeito, na história brasileira, é possível encontrarmos exemplos de surtos de demanda externa que resultaram tanto no crescimento econômico quanto no desenvolvimento econômico ${ }^{8}$.

No primeiro caso, temos o ciclo da borracha, que trouxe, durante algumas décadas, grande volume de riquezas para o Norte do Brasil. O influxo de capitais, entretanto, não foi hábil a promover o desenvolvimento da região, que se estagnou após a queda da demanda pela competição da borracha asiática. Como exemplo de desenvolvimento econômico estimulado pelas exportações, temos a cafeicultura no estado de São Paulo. A entrada de capital estrangeiro trouxe consigo a alteração das estruturas sociais, econômicas e políticas então existentes ${ }^{9}$. O período foi marcado pelo surgimento e crescimento de um mercado interno, indústrias, comércio, ferrovias, pela geração de empregos e de uma rede social que passou a movimentar a economia. A grande importância desse processo está no fato de

\footnotetext{
7 Utilizaremos a palavra "produto" como sinônimo de qualquer bem ou serviço que possa ser oferecido no mercado.

8 Verificaremos com vagar no Capítulo 7 que o desenvolvimento econômico é parte do desenvolvimento nacional.

9 "O desenvolvimento econômico implica mudanças na estrutura, na cultura e nas instituições da sociedade, de forma que é impossível analisá-lo apenas do ponto de vista econômico. Está, em primeiro lugar, associado a transformações no nível mais estável da sociedade que é o estrutural, porque a tecnologia é fator dinâmico por excelência, porque as formas de propriedade estão sempre evoluindo, e porque as classes e demais grupos sociais estão sempre em processo de mudança. Está associado também a mudanças culturais, principalmente às ideológicas que refletem interesses dos diversos grupos sociais permanentemente envolvidos em relações de conflito e cooperação. E está ligado a um permanente processo de mudança das instituições, que às vezes antecipam as transformações nos outros níveis, muitas vezes lhes servem de obstáculo, e na grande maioria das vezes buscam apenas dar conta das mudanças estruturais e culturais que estão ocorrendo" (LUIZ CARLOS BRESSER-PEREIRA, Desenvolvimento econômico e revolução capitalista, Texto para discussão EESP/FGV 170, out. 2008, p. 17).
} 
que, com o tempo, não mais havia a necessidade de estímulos externos, derivados da compra do café, sendo a economia local capaz de girar por seus próprios eixos.

A demanda externa por produtos brasileiros e os cartéis de exportação podem, portanto, ser propulsores para que possam ser atingidos os desejados crescimento e desenvolvimento econômicos ${ }^{10}$.

Vejamos, por outro lado, como a diminuição dos índices de exportação afeta a economia de um Estado.

A atual conjuntura econômica, marcada pela crise do ano de 2008, retrata com maestria os efeitos da diminuição na aquisição de produtos brasileiros. Uma das grandes preocupações mundiais hoje é que um dos grandes países consumidores, os Estados Unidos, está dando sinais de que seu comércio nos próximos meses (ou anos) não seguirá os mesmos patamares dos últimos, ou seja, o país comprará (e importará) menos do que o esperado $^{11}$.

Os reflexos dessa alteração nos padrões de consumo americano podem ser bastante severos. Tomemos, por exemplo, o setor citrícola brasileiro, responsável por grande parte do suco comercializado internacionalmente: é de se esperar que os Estados Unidos, diante da crise, comprem menor volume de suco de laranja. Os reflexos dessa redução, conforme adiantado, atingirão não somente a indústria do suco, mas deverão se espalhar por outros setores, atingindo até mesmo aqueles que não estão cientes de como uma crise mundial pode ser-lhes perniciosa. Os produtores de determinado tipo de trator utilizado na lavoura da laranja sentirão seus reflexos. Não só eles, mas também aqueles que produzem as correias utilizadas em tais equipamentos e aqueles que produzem seu combustível. Isso sem falar nos produtores da fruta e aqueles que trabalham em sua colheita. Os efeitos acima descritos referem-se apenas àqueles setores que possuem relação com a indústria do

10 É importante frisar que o trabalho não é uma ode a políticas irracionais e agressivas de exportação e que não ignoramos todos os meandros econômicos que cercam essa atividade.

11 Na explicação de OLIVIER BLANCHARD: "Quando, após três anos de pouco ou nenhum, crescimento, a recuperação dos EUA se tornou mais forte em 1993, os países em todo o mundo rejubilaramse. Não por morrerem de amores pelos EUA, mas porque viram que um produto maior dos EUA implicava maior demanda não só pelos bens americanos, como também pelos bens estrangeiros de um modo geral. Para eles, essa demanda maior representava maiores exportações para os EUA, uma melhoria em sua posição comercial, um aumento em seus produtos e, assim, uma oportunidade de crescer com maior rapidez e, dessa forma, ultrapassar suas próprias recessões" (Op. cit., p. 401). 
suco. A mesma queda no consumo deve ocorrer com outros produtos e serviços, em um efeito em cadeia que poderá atingir grande parte da economia.

Além disso, alterações na balança comercial brasileira poderão levar a mudanças nas políticas macroeconômicas, como as de taxas de juros e de precificação dos produtos transacionáveis, e mesmo a alterações nas políticas comerciais do Estado.

Como é de se perceber, a atividade de exportação, por sua importância e reflexos sobre a economia e o desenvolvimento do país, demanda constante atuação dos governos e dos formuladores de políticas públicas ${ }^{12}$. Essa relevância é reafirmada, nos últimos anos, pelo maior intercâmbio de produtos e informações nos mercados internacionais e pelo estreitamento das relações entre os países, creditados, especialmente, ao fenômeno da globalização $^{13}$. É evidente o trabalho dos Estados para a defesa de suas economias (e exportações), como podemos observar da criação de barreiras, subsídios e outras medidas de proteção econômica ${ }^{14-15}$. No caso brasileiro, encontramos a política de vultosos

12 Utilizaremos a expressão "política pública" no mesmo sentido que lhe é conferido por MARIA PAULA DALLARI BUCCI: "políticas públicas são programas de ação governamental visando a coordenar os meios à disposição do Estado e as atividades privadas para a realização de objetivos socialmente relevantes e politicamente determinados (Direito administrativo e políticas públicas, São Paulo, Saraiva, 2002, p. 241).

13 A globalização será mais bem discutida ao longo do Capítulo 5.

14 Apenas a título de exemplo, no dia em que esse texto foi escrito, foi publicada no Diário Oficial da União a Lei 11.793/08, que dispõe sobre a prestação de auxílio financeiro pela União aos Estados, ao Distrito Federal e aos Municípios para o fomento das exportações do País. Já em 30 de outubro de 2008 o Banco Central anunciou novo mecanismo para auxiliar os exportadores brasileiros, como forma de amenizar os efeitos da crise internacional. Nesse sentido, vide reportagem publicada pela Reuters International (BC lançará novo mecanismo para financiar exportadores, disponível em: http://br.invertia.com/noticias/noticia.aspx?idNoticia=200810301427_RTR_1225376175nN3066281\&idtel=, acesso em 30 out. 2008). Outra medida nesse mesmo sentido está na criação de um banco brasileiro voltado às exportações - o "Eximbank brasileiro". Sobre o tema, vide notícia publicada no G1 em 27 de maio de 2009: "A criação ainda este ano de uma estrutura administrativa dedicada exclusivamente a financiar as exportações e a produção destinada ao mercado exterior elevará o Brasil à mesma condição de outros países que já têm uma instituição similar, na avaliação do presidente do Banco Nacional de Desenvolvimento Econômico e Social (BNDES), Luciano Coutinho. 'É necessário que o Brasil tenha essa instituição, porque todos os países têm', afirmou ele, ao comentar as declarações do ministro do Desenvolvimento, Indústria e Comércio Exterior, Miguel Jorge, sobre o tema". (Criação de um banco de exportações para o Brasil é necessária, diz BNDES, disponível em: http://g1.globo.com/Noticias/Economia_Negocios/0,_MUL11694769356,00.html, acesso em 22 jun. 2009).

15 "Hoje, $90 \%$ dos bens comercializados no mundo já sofrem algum tipo de nova barreira e entidades internacionais pedem que, com a recuperação das economias, as medidas protecionistas também desapareçam. Para a Organização Mundial do Comércio (OMC), as barreiras são 'areia na engrenagem do comércio mundial. Segundo o Global Trade Alert, entidade formada por especialistas do Banco Mundial e do Reino Unido, 95 barreiras foram adotadas entre julho e setembro no mundo. Outras 130 medidas estão em estudo e ainda podem ser adotadas, incluindo a elevação de tarifas, aumento de subsídios à exportação e até barreiras a imigrantes'. [...]. As exportações brasileiras registraram queda nas três categorias de produtos básicos, semimanufaturados e manufaturados - nas duas primeiras semanas de setembro em relação à média 
investimentos efetuados pelo Banco Nacional de Desenvolvimento Econômico e Social BNDES para a criação de empresas capazes de "competir no exterior, criando receitas, empregos e influência para o País"16.

Dentro do quadro ora narrado, parece ser nítida a importância de instrumentos, como os cartéis de exportação, que sejam hábeis a estimular as exportações brasileiras. Nesse compasso duas importantes questões irão emergir ao longo do trabalho: i) a discussão sobre o papel do Estado na promoção de seu desenvolvimento; ii) a adequação da política concorrencial à princípios e objetivos trazidos pela Constituição Federal $^{17}$.

diária registrada em setembro de 2008. Segundo os dados do Ministério do Desenvolvimento, os valores dos produtos embaraçados no mês, de US \$ 5,256 bilhões, com média diárias de US\$ 657 milhões, ficaram 27,8\% abaixo da média diária de setembro do ano passado, por conta da retração de $33,8 \%$ nas vendas de manufaturados, de $27,8 \%$ dos semimanufaturados e 19,5\% nos básicos" (90\% do comércio mundial enfrenta novas barreiras, $O$ Estado de S. Paulo, 15 set. 2009, B4).

16 A criação de grandes grupos empresariais brasileiros, uma das principais ambições do governo Lula na área econômica, consumiu, em apenas um ano, pelo menos $\mathrm{R} \$ 8$ bilhões do Banco Nacional de Desenvolvimento Econômico e Social (BNDES). (DAVID FRIEDLANDER; IRANY TEREZA, BNDES gasta R\$ 8 bi em um ano para criar "campeões nacionais", O Estado de S. Paulo, 27 set. 2009, p. B1). "O BNDES (Banco Nacional de Desenvolvimento Econômico e Social) emprestou R \$ 18,49 bilhões dentro da linha especial para aquisição e exportação de bens de capital que oferece juros reduzidos, lançada no final de junho deste ano. A maior parte dos desembolsos foi utilizada para financiar as exportações de máquinas e equipamentos cerca de $\mathrm{R} \$ 8,3$ bilhões. O banco também liberou $\mathrm{R} \$$ 5,5 bilhões para a aquisição de máquinas e $\mathrm{R} \$ 4,5$ bilhões para a compra de ônibus e caminhões. A procura por financiamento à exportação se deve à restrição ao crédito e à redução da taxa de juros do BNDES e não a um aquecimento das vendas externas, afirma o diretor de financiamentos da Abimaq (Associação Brasileira das Indústrias de Máquinas e Equipamentos), Carlos Nogueira. 'O cenário internacional está desfavorável e o câmbio atual dificulta as vendas externas. Não houve aumento, mas redução das exportações neste ano', diz Nogueira”. (MARINA GAZZONI, BNDES liberou $R \$ 18$ bilhões com juro reduzido para financiar bens de capital, Último Segundo, disponível

em: http://ultimosegundo.ig.com.br/economia/2009/12/04/bndes+liberou+r+18+bilhoes+com+juro+reduzido+par a+financiar+bens+de+capital+9194956.html, acesso em 4 dez. 2009). Ainda nesse sentido: "O ministro da Fazenda, Guido Mantega, anunciou nesta quarta-feira (9) que o governo vai abrir uma linha de crédito de R\$ 80 bilhões para o Banco Nacional de Desenvolvimento Econômico e Social (BNDES) emprestar recursos ao setor privado em 2010 e 2011. Neste ano, o governo já aportou R \$ 100 bilhões no banco público de fomento. "De modo que o BNDES poderá prosseguir com os programas de financiamento com juros reduzidos", acrescentou o ministro. O governo cobrará, do BNDES, juros balizados pela Taxa de Juros de Longo Prazo (TJLP), atualmente em $6 \%$ ao ano. Além disso, Mantega informou que também será prorrogado, até 30 de junho de 2010, a desoneração para compra de bens de capital (máquinas e equipamentos para a produção). 'De vários itens que estão com praticamente IPI zero', disse ele. Sem a prorrogação, o benefício terminaria no fim deste ano. Os principais itens beneficiados: válvulas industriais, árvores de transmissão, microscópios eletrônicos, hastes para bombeamentos e congeladores industriais, entre outros. A estimativa é de que o governo deixará de arrecadar R\$ 369 milhões com a medida em 2010”. (ALEXANDRO MARTELLO, Governo vai abrir linha de crédito de R\$ 80 bilhões para o BNDES, diz Mantega, G1, disponível em: http://g1.globo.com/Noticias/Economia_Negocios/0,_MUL1408791-9356,00-

GOVERNO+VAI+ABRIR+LINHA+DE+CREDITO+DE+R+BILHOES+PARA+O+BNDES+DIZ+MANT EGA.html, acesso em 9 dez. 2009).

17 Necessário que se atente para as diferenças existentes entre a "política da concorrência" e o regramento da concorrência, conforme aponta DANIEL GOLDBERG: "[...] denominamos política de concorrência a conjunção de: (i) a prática das autoridades da concorrência e tribunais que, interpretando e aplicando o conjunto de normas vigentes para perseguir determinado objetivo, confere um caráter dinâmico 
É dentro desses termos que entendemos válidos e importantes estudos que versem sobre instrumentos de fomento às exportações e justificamos a escolha do tema deste trabalho, deixando registrada nossa surpresa com a escassez de literatura, especialmente nacional, sobre o assunto ${ }^{18}$.

às regras antitruste, (ii) a edição de normas em abstrato que tenham impacto sobre mercados livres ou regulados (i.e., política legislativa) e, por último, (iii) os critérios governamentais que pautam a alocação de recursos a uma ou outra prioridade, sobre as quais, discricionariamente, pode dispor qualquer autoridade de concorrência. Nesse contexto, define-se a política da concorrência como espécie de política pública" (Poder de Compra e Política Antitruste, São Paulo, Singular, 2006, p. 28). ADITYA BHATTACHARJEA nos apresenta alguns dos itens que compõem a política comercial: "Competition policy may also encompass a range of other government measures that affect competition, such as policies towards international trade, foreign investment, increasing, regulation, taxation, government procurement and standard-setting" (Trade and Competition Policy, Indian council for research on international economic relations, Working Paper $n$. 146, ICRIER, New Delhi, 2004, p. 1).

18 Com relação a tema ainda mais abrangente, como o do controle dos comportamentos anticoncorrenciais, afirma CALIXTO SALOMÃO FILHO: "Talvez não seja exagerado dizer que o controle dos comportamentos anticoncorrenciais é um dos mais descurados campos do Direito Brasileiro. Poucos são os trabalhos compreensivos sobre o tema e escassa tem sido, até agora, a atenção das autoridades encarregadas da aplicação do direito antitruste para esse ramo do direito concorrencial. Parece não haver, sobretudo, uma preocupação em compreender sistematicamente o significado econômico-jurídico dos comportamentos anticoncorrenciais" (Direito concorrencial - as condutas, São Paulo, Malheiros, 2003, p. 18). Mesmo na literatura internacional, poucos dados e estudos estão disponíveis. Nesse sentido ADITYA BHATTACHARJEA, Export cartels, a developing country perspective, Working Paper n. 120, Center for Development Economics (CDE), Department of Economics, Delhi School of Economics, 2004. 


\section{PRIMEIRAS OBSERVAÇÕES NECESSÁRIAS}

Já afirmamos no Capítulo inicial que esse é um estudo sobre a possibilidade de utilização dos cartéis de exportação dentro do ordenamento jurídico brasileiro. Dentro desse prisma, daremos relevância às questões que nos são trazidas pelo direito constitucional e pelo direito concorrencial. O corte é necessário para que a pesquisa possa ser aprofundada, mas por outro lado, nos ressentimos da falta de uma análise mais completa e multidisciplinar, especialmente aquelas trazidas pelo direito internacional. Vamos agora justificar a escolha por examinarmos mais detidamente esses dois campos do direito.

Apesar de o trabalho versar sobre tema eminentemente afeto à concorrência, não é possível prescindirmos da análise do texto constitucional. É ele quem nos apresentará as linhas mestras a serem seguidas quando do estudo do ordenamento pátrio. Com efeito, a Constituição Federal de 1988 é o documento fundamental do ordenamento jurídico brasileiro - nos dizeres de JOSÉ AFONSO DA SILVA, o vértice do sistema. Seu texto é que confere validade a todo o restante da legislação, que se coloca sempre abaixo de seus $\operatorname{preceitos}^{19}$.

Isso porque a Constituição, sendo um ato de soberania, de declaração da vontade política do povo, insere-se na compreensão do fenômeno jurídico como o documento positivado superior às demais normas. A Constituição, ao transformar o ato político em direito positivo, guarda relação com o pressuposto de validade das normas ${ }^{20}$.

Sob o aspecto material, ela é o conjunto de normas pertinentes à organização do poder estatal, à distribuição de competências administrativas e judiciárias, à forma de governo adotada, aos direitos individuais dos cidadãos, entre outros aspectos fundamentais.

19 A Constituição "se coloca no vértice do sistema jurídico do país, a que confere validade, e que todos os poderes estatais são legítimos na medida em que ela os reconheça e na proporção por ela distribuídos" (Curso de direito constitucional positivo, 16. ed., São Paulo: Malheiros, 1999, p. 47).

20 Para estudo mais aprofundado, consultar GILBERTO BERCOVICI, Constituição e política: uma relação difícil, Revista Lua Nova, n. 61, São Paulo, 2004, p. 5-24. 
Em suma, a constituição delineia "a relação dos súditos com o poder estatal", consoante célebre expressão de HANS KELSEN. Não por outro motivo afirma FERDINAND LASSALLE que "não há Estado sem constituição".

A aceitação desse pressuposto de que a Constituição é "a lei fundamental, é um conjunto de normas articuladas que tecnicamente viabilizam os procedimentos para que a sociedade possa se desenvolver" 21 é fundamental para que se possa encontrar soluções para os conflitos que emergem do cotidiano. Ao se deparar com o caso concreto, o jurista busca encontrar a resposta ao seu questionamento no ordenamento de forma racional e escalonada, conferindo sua validade em confronto com o texto constitucional.

Nesse sentido, deve-se atentar para o fato de que a interpretação da Constituição leva em consideração as peculiaridades de suas normas, em especial i) sua supremacia sobre o restante do ordenamento; ii) a natureza da linguagem do texto constitucional, calcada em conceitos abertos e abstratos, em sua grande maioria; o fato de que iii) as normas constitucionais têm conteúdo específico, pois não regulam aspectos cotidianos, mas sim instituem a organização do Estado, os direitos dos cidadãos etc.; e, por fim, iv) o caráter político da norma, instituída por ato de vontade soberana.

Apesar das observações poderem parecer corriqueiras, são de grande valia para esse estudo. A uma porque será necessário que analisemos a lei concorrencial brasileira (a Lei 8884/94) de acordo com os princípios e objetivos estabelecidos pelo constituinte, e não o contrário. A duas porque os cartéis de exportação são um tema eminentemente polêmico, sendo as opiniões emitidas a seu respeito permeadas de vieses ideológicos e devem, necessariamente, ser discutidos à luz de seus preceitos. A três porque, nos últimos anos, estamos observando uma tendência de relativizar-se ou não conferir às normas constitucionais a importância que lhes é devida. Isso ocorre, com maior frequência, naquelas disciplinas que são alvo de doutrinas estrangeiras, como é o caso do direito concorrencial.

Tendo sido feitas essas considerações, passemos a algumas observações sobre o direito antitruste, que é definido por ISABEL VAZ como o conjunto de regras destinadas a

21 TÉRCIO SAMPAIO FERRAZ JÚNIOR, Introdução ao Estudo do Direito; técnica, decisão, dominação, 2 ed., São Paulo, Atlas, 1984, p. 231. 
reprimir o abuso de poder econômico e a promover a concorrência ${ }^{22-23}$. Com efeito, trata-se de dispositivos responsáveis por indicar o comportamento a ser seguido pelos agentes que atuam no mercado.

A influência dessas normas perpassa o que conhecemos estritamente como direito concorrencial (controle de atos de concentração, cartéis, acordos verticais, etc) e atinge também outras áreas, como o comércio internacional, a política industrial, entre outras ${ }^{24}$. FLORIAN BECKER fala sobre essa relação tendo em vista o objeto desse estudo: "Export cartel exemptions are instruments of competition policy for trade policy ends ${ }^{25}$ ". Nesse caso, apesar de o controle dos cartéis de exportação estar ligado à preocupação sobre a concorrência no mercado internacional, uma análise mais ampla nos revela que, ao final, o intuito de sua disciplina é o de estimular as exportações do país. Dessa interação com

22 Direito Econômico e Concorrência, Rio de Janeiro, Forense, 1993, p. 243. PINDYCK e RUBINFELD afirmam que "o objetivo primário das leis antitruste é a promoção de uma economia competitiva, por meio da proibição de ações que sejam capazes de limitar, ou tenham possibilidade de limitar a concorrência, e por meio de restrições à estruturas de mercado que sejam permissivas" (Microeconomia, 4. ed., São Paulo, Makron Books, 1999, p. 393).

23 Sobre a autonomia do Direito Antitruste, afirma MANOEL JORGE E SILVA NETO: "Não consideramos, destarte, que o direito da concorrência configure ramo didaticamente autônomo do sistema da ciência do direito, eis que os princípios que o regem são os mesmos a nortearem o Direito Econômico" (Direito Constitucional Econômico, São Paulo, LTR, 2001, p. 174). ato de concentração entre duas empresas que fora fomentado por uma política industrial de fortalecimento de empresas nacionais. Nesse ponto, interessante comparar os posicionamentos antagônicos do BNDES e do Presidente do Conselho Administrativo de Defesa da Concorrência sobre a criação dos "campeões nacionais": "Logo após a quebra da Bolsa de 1929, toma posse nos Estados Unidos o presidente Franklin Roosevelt com uma grande expectativa popular e mundial de que resolveria o problema. E quais foram as políticas adotadas nos primeiros anos do New Deal? Protecionismo, limitação do comércio internacional. O Estado favoreceu a criação de cartéis na economia. (Com que argumento?) O de que em momentos de crise é preciso criar grandes campeões nacionais para ganhar mercado no exterior. Isso agravou a crise. Muitos dizem que essas medidas de diminuição do comércio internacional, e mesmo local, acabou gerando o agravamento da crise que, no limite, levou à Segunda Grande Guerra. É preciso estar atento para não cair na mesma cantilena da década de 30. Para enfrentar a crise, é preciso recrudescer a política antitruste" (Entrevista concedida ao portal Consultor Jurídico, em 28 de maio de 2009, disponível em http://www.cade.gov.br/Default.aspx?fa4edc2cc55bb17185b286da75, acesso em 18 jun. 2009). Posicionamento do BNDES sobre o tema: "[...] A meta é incentivar a criação de companhias capazes de competir no exterior, criando receitas, empregos e influência para o País" (DAVID FRIEDLANCER; IRANY TEREZA, op. cit).

25 E continua, citando P. STEPHAN: "In a world of international trade, competition and trade policy also become the same subject. Trade policy at its heart involves choices over the level of competition between domestic and foreign producers a state will permit or encourage... Absent close economy, competition and trade policy are the two sides of the same coin" (Op. cit., p. 99). No mesmo sentido ANDRÉ R. FIEBIG: "The fact that there are few clear lines in the application of competition law makes it difficult to identify correct results and as such to preclude the political instrumentalization of the law" (The German Federal Cartel Office and the application of competition law in reunified Germany, 14 U. Pa. J. Int'l Bus. L. 373, 1993-1994, p. 387). 
outros campos emergirá uma série de questões, inclusive a necessidade de harmonização, que serão discutidas ao longo do trabalho ${ }^{26}$.

Apesar de a disciplina concorrencial estar presente na legislação brasileira há algumas décadas, sua aplicação deixou de ser incipiente há poucos anos, tendo como ponto de mutação a edição da Lei 8884/94 e o processo de globalização da década de 1990. No exterior, a utilização é mais antiga e remonta ao alvorecer do século XIX, com a edição do Sherman Antitrust Act nos Estados Unidos ${ }^{27}$.

Um aspecto interessante do direito concorrencial é a diversidade de interpretações conferidas às suas normas. Com efeito, inúmeras Escolas de pensamento reclamam possuir o "método correto" para sua visualização, indicando, cada uma delas, objetivos diversos a serem perseguidos. O estudo dessas Escolas ultrapassa o mero interesse acadêmico: a influência que cada uma delas traz para o direito concorrencial pode ser fundamental para que se considere viável ou não a existência dos cartéis de exportação.

Por esse motivo, a despeito de poder parecer precipitado que no segundo Capítulo deste trabalho já se trate de tema tão específico, achamos importante que, desde logo, se apresentem as principais influências que marcam a aplicação do direito concorrencial e que sejam sublinhados os objetivos perseguidos por uma e por outra Escola ${ }^{28}$. Esse

26 Ainda nesse sentido, observar a matéria da Gazeta Mercantil, trazendo o entendimento de LUCIANO COUTINHO sobre a interação entre política da concorrência e desenvolvimento: "o grande desafio é compatibilizar a política de concorrência com a política de desenvolvimento. Apesar das divergências possíveis entre as duas, ressaltou que a conciliação é necessária. Segundo Coutinho, uma política de desenvolvimento contemporânea deve ter a competitividade como critério, que é a capacidade de participar do comércio internacional sem suportes diferenciados. Isso significa, entre outras coisas, a calibragem da proteção tarifária, além da diminuição de subsídios. Ele considera que uma das principais falhas da política de desenvolvimento é a falta de regras claras. Para Coutinho, ela deve buscar a maximização da competitividade, ou seja, tem que ter eficiência com o máximo de competição no mercado doméstico e regional. Do lado da política de concorrência, disse que esta deve aumentar a eficácia das punições às práticas cartelizantes, bem como ampliar a transparência dos controles públicos. 'Do lado da política de desenvolvimento, me parece fundamental que as autoridades públicas, como o setor privado, tenham compreensão do papel positivo da concorrência para a eficiência, para a inovação e para a equidade', falou. A seu ver, a compreensão da política de desenvolvimento - e do valor da concorrência - é essencial para uma convergência" (SILMARA COSSOLINO, Concorrência: momento é de amadurecimento, diz Coutinho, Gazeta Mercantil, $14 \quad$ set. $2004, \quad$ disponível em: http://indexet.investimentosenoticias.com.br/arquivo/2004/09/14/198/CONCORRENCIA-Momento-e-deamadurecimento-diz-Coutinho.html, acesso em 27 maio 2009).

27 Primeiro diploma antitruste do mundo, assim considerado pela representatividade que alcançou nos tempos modernos, não nos esquecendo do fato de a legislação canadense (Canada's 1889 Combines Investigation Act) ser-lhe anterior.

28 "Se é verdade que as normas de concorrência são essenciais para orientar o comportamento econômico dos agentes, deve-se, em seguida, perguntar em que sentido elas indicam. É na resposta a essa 
procedimento propiciará uma visão mais crítica sobre as discussões que serão travadas nos Capítulos seguintes e permitirá que se identifique a origem de conceitos arraigados na linguagem do antitruste como, por exemplo, o da busca pela eficiência econômica.

Como existem inúmeros trabalhos a dissecarem as Escolas do direito concorrencial, buscaremos, de forma bastante resumida, analisar as seguintes, sempre dando enfoque ao quê de necessário para o estudo dos cartéis de exportação: i) a Escola Estruturalista de Harvard; ii) a Escola de Chicago; iii) a Escola de Freiburg; e iv) outras formas de entendimento da matéria ${ }^{29}$.

Antes de nos embrenharmos sobre o assunto, é necessário observar que não há divisão estanque entre uma e outra teoria apresentada, sendo elas, em muitos casos, complementares.

\subsection{A Escola Estruturalista de Harvard}

A Escola Estruturalista de Harvard surgiu nos Estados Unidos nos idos da década de 1940 e tinha em AREEDA, SULLIVAN e TURNER seus grandes expoentes. Sua principal característica é a preocupação com o arranjo concorrencial dos mercados. Esses doutrinadores buscam a existência de mercados competitivos, assim definidos por AREEDA e TURNER: "The competitive market is one in which power is not unduly concentrated in the hands of one or few firms. They are sufficiently numerous to offer real alternatives to their suppliers and customers, whose fate is thus determined by impersonal market forces rather than by the arbitrary fiat of another. And the several firms that share that market will necessarily have less individual economic or political significance than would be had by a single firm, or by substantially fewer firms, controlling the market" 30 .

pergunta que se encontra a mais importante divergência da teoria econômica em matéria de sistema antitruste" (CALIXTO SALOMÃO FILHO, Direito concorrencial - As estruturas, 3. ${ }^{\circ}$ Ed., São Paulo, Malheiros, 2002, p. 22).

29 Para aprofundamentos sobre o tema, consultar as obras de CALIXTO SALOMÃO FILHO e PAULA A. FORGIONI.

30 SULLIVAN e HOVEMKAMP, Antitrust law, policy and procedure: cases, materials, problems, Charlottesvile, Lexis Law Publishing, 1999, p. 7-25. 
Seus ensinamentos dão ênfase aos malefícios originados da concentração do mercado, geralmente relacionada com a alteração das condições naturais de concorrência, ao abuso de poder dominante ${ }^{31}$ e à possibilidade de colusão entre os agentes. ${ }^{32}$.

Com efeito, as teorias econômicas que se desenvolveram ao longo do século passado passaram a demonstrar que a dinâmica de um mercado concentrado se dava de forma diferente daquela encontrada nos pulverizados. Isso porque o volume de mercadorias produzido pelas corporações detentoras de alto market share e mesmo o poder econômico do qual desfrutam permitem que elas tenham certas vantagens e economias que as empresas menores não logram obter. O resultado disso, muitas vezes, é a distorção nas condições de competição, levando a uma clara vantagem para as de maior porte ${ }^{33}$. Para os teóricos de Harvard, essa diferenciação artificial entre os agentes econômicos é problemática: como veremos no Capítulo 3, o mercado ideal seria aquele disputado por inúmeras empresas, em um ambiente pulverizado no qual elas não pudessem individualmente alterar as regras do jogo, ou agir independentemente.

$31 \quad$ ANA MARIA NUSDEO assim diz sobre o poder de mercado: “[...] é definido a partir da capacidade de o agente de aumentar substancialmente os preços de seus produtos de modo a maximizar seus lucros, por um certo período de tempo. A existência dessa possibilidade não significa ser sempre uma conduta adotada, pois o agente pode optar pela redução predatória de preços para afastar a concorrência. Embora relacionado com a dimensão da participação de mercado do agente, o poder de mercado não se identifica plenamente com essas categorias, pois sua capacidade de aumentar preços pode estar sendo restringida pela possibilidade de os consumidores trocarem seus produtos por outros, substitutos, ou de novos agentes ingressarem no mercado, atraídos pela sua alta lucratividade, e, assim, aumentar a concorrência na venda do produto em questão" (Defesa da Concorrência e Globalização Econômica: o controle da concentração de empresas, São Paulo, Malheiros, 2002, p. 28-29).

32 JOSÉ MARCELO MARTINS PROENÇA enuncia outros malefícios desse tipo de estrutura: "Atribui-se, ainda, às estruturas concentradas a responsabilidade pela ausência de concorrência em preço e a excessiva concorrência em diversificação do produto, calcada na publicidade exagerada, orientada a influir o consumidor quanto à superioridade dos produtos e obter fatias adicionais do mercado. Os altíssimos valores despendidos em publicidade pelas empresas dominantes seriam, de acordo com os estruturalistas, uma maneira de assegurar a concentração de mercado, desencorajando a concorrência potencial, sendo certo ainda que os montantes empregados em propaganda com o objetivo de canalizar as preferências do consumidor para a marca e não para o preço poderiam estar mais adequadamente empregados em pesquisa $\mathrm{e}$ desenvolvimento. Outra característica negativa que se aponta no mercado concentrado é a existência de barreiras à entrada de novos concorrentes, consubstanciadas nas vantagens que detêm as empresas que o integram, tais como a capacidade de diferenciação de produto, custos mais baixos decorrentes do controle sobre técnicas de produção, redes de distribuição e fatores de distribuição e vantagens que tornam mais altos os custos de entrada, desencorajando concorrentes potenciais" (Título VII das formas de controle, Capítulo I - Do controle de atos e contratos, In MARCOS DA COSTA et al.. (Coord.), Direito concorrencial: aspectos jurídicos e econômicos: comentários à Lei n. 8.884/94 e estudos doutrinários, Rio de Janeiro: América Jurídica, 2003, p. 385).

33

Este tema será mais bem abordado no Capítulo 3. 
É interessante verificar que o âmago da questão estruturalista não estava no tamanho das corporações considerado isoladamente, mas na participação que as empresas detinham no mercado - ou seja, no seu tamanho quando comparado ao das demais. Dessa forma, não haveria qualquer problema em que o mercado fosse dividido entre grandes conglomerados mundiais, desde que cada um deles fosse responsável por uma pequena quantidade do total de produtos ofertados.

Referimos acima que um outro problema apontado pela Escola de Harvard para mercados concentrados seria a possibilidade dos agentes virem a abusar de sua posição dominante $^{34}$. Em mercados concentrados, não é raro que players deixem de agir com respeito às condições mínimas de competição para com seus pares e mesmo para com os consumidores e fornecedores. Como exemplo, pode-se entender a importância/necessidade do controle sobre esse tipo de estrutura: suponhamos uma estrada de ferro, única a cortar o território de determinado país, transportando toda sorte de produtos do interior até o porto, e um passageiro que deseja ir ao litoral. Dada a superioridade de posição negocial da estrada de ferro em face do viajante, ela poderia cobrar o preço que melhor lhe aprouvesse desse passageiro, ao qual restariam apenas duas saídas: pagar o quanto exigido ou deixar de viajar.

Essa mesma estrada de ferro pode ainda adotar comportamento anticoncorrencial, consubstanciado na diferenciação tarifária entre os agentes econômicos que utilizam seus serviços. Valendo-nos da mesma situação acima, imaginemos que no mesmo grupamento societário da ferrovia haja também uma empresa produtora de milho com a qual um pequeno agricultor concorre. Não seria difícil supor que a ferrovia poderia passar a discriminar o produtor, oferecendo transporte extremamente caro (ou mesmo negando-se a realizar o transporte de seus produtos) na tentativa de eliminar do mercado o concorrente.

Nas situações descritas é patente o poder e o abuso de mercado da estrada de ferro sobre o viajante e sobre o produtor de milho. A idéia defendida pelos teóricos de Harvard é de que eles não existiriam (ou seriam brutalmente reduzidos) caso houvesse um grande número de estradas de ferro oferecendo seus serviços no mercado, ou seja, se o mercado não fosse tão concentrado.

34 Para melhor análise do tema, indispensável a leitura da obra de CALIXTO SALOMÃO FILHO, Direito concorrencial - as condutas, cit. 
A luta por um mercado pulverizado não tem como fim "proteger" os agentes de menor porte (mais fracos). Quer apenas criar condições para que o mercado funcione da maneira mais próxima possível a um mercado competitivo, com inúmeros players disputando a preferência dos consumidores. Aí se torna necessária a atuação do Estado caso se permita que os agentes ajam livremente, sem qualquer tipo de disciplina, com o passar do tempo, iríamos observar a concorrência enfraquecida, dominada apenas pelas grandes corporações. Isso porque o fôlego financeiro dessas empresas permite que eliminem os competidores menores da arena concorrencial para construírem, ao final, uma posição bastante confortável para aquelas que logram permanecer no mercado

Uma última motivação encontrada pela Escola de Harvard para evitar a formação de estruturas concentradas é a maior probabilidade de formação de conluio entre as empresas. A afirmação é feita com base nos modelos de estrutura-conduta-desempenho desenvolvidos por MASON e CLARCK. Explica-se: uma das condições necessárias para que possa ocorrer um acordo bem-sucedido entre competidores é a existência de poucos agentes no mercado que, dentre desse contexto, são capazes de se organizar e monitorar uns aos outros. Esses arranjos são ainda mais profícuos caso existam altas barreiras à entrada de novas firmas no mercado. Com efeito, se não fossem necessários altos investimentos para a entrada no mercado, os altos preços praticados e as taxas de lucro exorbitantes advindos do conluio atrairiam para o mercado outros competidores interessados nesses atrativos, o que colocaria em risco a existência do acordo ${ }^{35-36}$.

Trazendo esses ensinamentos para nosso trabalho, podemos encontrar interessantes justificativas para que os cartéis de exportação possam ser utilizados. Como é de se notar

35 Barreiras à entrada podem ser consideradas fatores que dificultem a entrada de novos players no mercado considerando-se um horizonte de longo prazo, permitindo que a indústria já estabelecida no mercado aufira lucros superiores aos normalmente esperados.

36 "Os estudos sobre essas relações entre estrutura, conduta e desempenho no mercado são marcados pela influência da doutrina desenvolvida entre os anos 30 e 70 nos Estados Unidos, com forte ênfase na influência da estrutura no funcionamento dos mercados. Essa doutrina, conhecida como paradigma da estrutura-conduta-desempenho, tem como proposição principal a existência de uma relação inerente entre a estrutura nos mercados e seu funcionamento. Nesse sentido, agentes atuantes em mercados onde existam alto grau de concentração e altas barreiras à entrada forçosamente adotam condutas anticompetitivas, daí resultando um baixo desempenho dos mercados, sob a forma de redução da produção e aumento de preços. A forte ênfase nos efeitos da estrutura no desempenho dos mercados, pelos adeptos da teoria, implicou até mesmo a redução da análise do comportamento efetivo dos agentes atuantes no mercado, pois a existência de estrutura favorável ao comportamento anticoncorrencial certamente levaria os agentes a adotarem-no." (ANA MARIA NUSDEO, op. cit., p. 42). A esse respeito, consultar também PAULA A. FORGIONI, Os fundamentos do Antitruste, 3. ${ }^{\circ}$ Ed., São Paulo, Revista dos Tribunais, 2008, p. 167 e ss. 
(e teremos a oportunidade de aprofundar no Capítulo 6), o comércio internacional não é composto por pequenos agentes, mas é dominado por grandes conglomerados transnacionais ${ }^{37}$, detentores de grande poder de mercado e capazes de lidar com os altos custos de ingresso nesses ambientes. Nesse cenário, os cartéis de exportação podem ser instrumentos para a promoção de maior competitividade no mercado (e mesmo de sobrevivência de algum tipo de competição), visto que: i) agregam um novo competidor ao mercado, tornando-o mais diluído; e ii) caso sejam capazes de competir, poderão desafiar o market-share dos agentes que lá se encontram ${ }^{38}$. Mais uma vez, aqui, não se trata de defender agentes mais fracos (ou seja, não se trata de permitir que se unam por serem menores), mas apenas de procurar viabilizar a existência de um mercado mais competitivo, com maior número de atores.

Com o passar dos anos a influência da Escola de Harvard foi arrefecida, especialmente pelo desenvolvimento de novos postulados econômicos que passaram a desafiar os seus fundamentos. Nesse momento, a Escola de Chicago passa a dominar as discussões sobre o direito concorrencial ${ }^{39}$. É do que se passa a tratar.

\subsection{A Escola de Chicago e a proteção à eficiência alocativa ${ }^{40}$}

A famosa Escola de Chicago vem influenciando sobremaneira a aplicação do direito concorrencial, especialmente nos Estados Unidos, desde a década de 1970.

Para que possamos entender as origens de grande parte de seus fundamentos, é de rigor uma breve incursão sobre a economia clássica e neoclássica, fontes nas quais muitos

37 Utilizaremos o termo "transnacionais" como referente à empresas originárias de um único país, mas que possuem atuação global. As multinacionais, por outro lado, estariam mais ligadas à empresas que se originam da associação de outras, especialmente oriundas dos países em desenvolvimento.

38 Esse tema será mais bem abordado ao longo do Capítulo 4.

$39 \quad$ "A partir sobretudo do final dos anos 70 pode-se dizer que a 'Escola de Harvard' simplesmente desaparece, já que seus representantes aceitam grande parte dos pressupostos da Escola de Chicago, que hoje domina e tem enorme influência nas cortes [...]" (CALIXTO SALOMÃO FILHO, Direito concorrencial - as estruturas, cit., p. 22-23).

40 "Embora a análise econômica forneça percepções valiosas da dinâmica empresarial e dos prováveis efeitos de determinada prática comercial no mercado, a economia não é a lei” (SHYAN KHEMANI (org.), Diretrizes para elaboração e implementação de política de defesa da concorrência, São Paulo, Singular, 2003, p. 36). 
de seus expoentes, como ROBERT BORK e RICHARD POSNER, buscaram inspiração. Utilizaremo-nos da descrição oferecida por ANTÓNIO JOSÉ AVELÃS NUNES para elencar as principais "leis" trazidas por essas linhas de pensamento:

A primeira é a Lei do interesse pessoal, segundo a qual o melhor arranjo de mercado ocorre quando os agentes agem livremente, unicamente na busca por seus próprios interesses. Aqui se aceitam pressupostos econômicos para a compreensão do comportamento humano, especialmente no sentido de que os agentes sempre adotam a escolha maximizadora de seus interesses (escolhas egoístas e que levam ao grau máximo o seu bem-estar), e que não levam em consideração quaisquer outros fatores de ponderação para a tomada de suas decisões. Além disso, há a suposição de que os indivíduos dispõem de todas as informações necessárias para que possam livremente atuar no mercado (ou seja, não há que se falar em racionalidade limitada).

A segunda é a Lei da livre concorrência. Defende-se que os agentes deveriam desfrutar do maior grau de liberdade possível, sem se defrontar com interferências artificiais não necessárias. O mercado seria o responsável por estabelecer o seu melhor arranjo, que atenderia, da melhor maneira, aos interesses individuais. Os ajustes eventualmente necessários seriam realizados pela atuação da "mão invisível", sendo desnecessária qualquer atuação proativa do Estado.

A terceira é a Lei da oferta e da procura. Segundo esses ensinamentos, a quantidade de bens oferecidos no mercado determina o preço pago pelos consumidores e vice-versa.

A última é a Lei do comércio internacional. Esse postulado se contrapõe à idéia de que apenas os países desenvolvidos se beneficiam do comércio internacional, pois afirma que os benefícios são distribuídos entre todos os seus membros. Uma das consequências da dessa Lei é a busca por um comércio entre países livre, sem interferências externas, nos mesmos moldes daquele buscado pela Lei da livre concorrência.

Devemos ainda nos atentar para outros ensinamentos da Escola Clássica/Neoclássica que vão trazer características marcantes para a Escola de Chicago, quais sejam:

i) a idéia de que as leis econômicas seriam como leis naturais, aptas a explicarem qualquer fenômeno, independentes de características peculiares. Acreditava-se que uma 
fórmula econômica utilizada com sucesso na Inglaterra poderia ser empregada com êxito na Austrália, sem necessidades de serem observadas as especificidades de cada país ${ }^{41}$.

ii) a idéia de que existem leis universais de equilíbrio (como as acima citadas) que deveriam ser estudadas e compreendidas pelo homem.

iii) a idéia de que as leis naturais não deveriam ser alteradas pela ação humana, visto que são justas. O que se deveria buscar, ao contrário, é que as leis seguissem a sua ordem natural, o que levaria ao progresso da sociedade.

iv) a não interferência nas leis naturais incluía também uma abstenção na atuação do Estado, que seria incompetente, em sua gênese, para lidar com qualquer matéria de cunho econômico. O lema é a não intervenção do Estado na economia ${ }^{42}$.

Além dos pressupostos ora elencados, não podemos nos esquecer de outras importantes hipóteses da teoria neoclássica, que também colaboraram para a elaboração

$41 \quad$ FABIO NUSDEO nos brinda com explicação sobre a busca por leis naturais: "Dentre os eventos que influenciaram a grande opção liberal do último quartel do século XVII é de se destacar aqueles ocorridos no campo das próprias descobertas científicas, pois estas produziram explicações para os fenômenos do mundo físico que, com base na analogia, acabaram sendo transpostas para o campo das relações sociais e econômicas. Com efeito, os empresários de meados do século XVIII estavam, evidentemente, interessados em divulgar uma base de argumentação científica para eliminar as últimas peias do feudalismo e do mercantilismo que tolhiam os seus movimentos. E as formulações, primeiro de Galileu, o pai da ciência experimental, e depois de Keppler e Newton, este morto não muito tempo antes, vinham a calhar ao demonstrarem haver uma ordem natural imposta e querida por Deus para reger o universo, a qual, naturalmente, mantinha em equilíbrio os corpos astrais. Assim, como a natureza respondia por tal equilíbrio, também na sociedade dever-se-ia adotar uma ordem natural, responsável pelos melhores resultados humanamente possíveis para todo o conjunto de cidadãos e pelo equilíbrio entre eles, ordem essa que não poderia ser contrária aos desígnios da divindade" (Fundamentos para uma codificação do Direito Econômico, São Paulo, Revista dos Tribunais, 1995, p. 10-11).

42 Nas palavras de ANTÓNIO JOSÉ AVELÃS NUNES “A Escola Clássica assentou basicamente na defesa da existência de um mecanismo natural que asseguraria sempre o equilíbrio da vida econômica e que, automaticamente, restabeleceria a ordem econômica porventura alterada. É com base nessa concepção que os clássicos consideram que a tarefa da ciência econômica é a investigação e descoberta das leis naturais que regulam todo aquele mecanismo, leis válidas em qualquer tempo e lugar, leis universais que o homem, através da observação e do estudo, pode apreender, devendo, aliás, fazê-lo para poder assegurar-se o progresso da sociedade. [...] Deste 'fetichismo naturalístico' (Oskar Lange) derivam duas atitudes características do pensamento dos clássicos: a) Por um lado, uma atitude conformista perante as ocorrências da vida econômica: elas decorrem de leis da natureza e o que é natural é justo (a lei moral identifica-se com a lei natural). b) Por outro lado, uma atitude de condenação de toda e qualquer intervenção do estado na vida econômica. Em $1^{\circ}$ lugar, porque a vida econômica e a ordem social são vistas como ordem natural, regulada por leis que exprimem princípios eternos e universais da natureza humana, leis tão rigorosas e inalteráveis como as leis da física (concepção mecanicista ou fisicista, de raiz newtoniana); em $2^{\circ}$ lugar, porque defendem que o estado, como máquina essencialmente política, é pelas suas próprias funções, incompetente para a actuação econômica. De acordo ainda com as palavras de Smith, 'não há dois caracteres que pareçam mais contrários do que os do comerciante e do governo'. Daí que os clássicos preconizem a total liberdade econômica" (Uma introdução à Economia Política, São Paulo, Quartier Latin, 2007, p. 378-379). 
dos ideais da Escola de Chicago, quais sejam: a inexistência de barreiras à entrada e à saída das empresas no mercado, não havendo que se falar em qualquer custo adicional para que isso ocorresse; o marginalismo econômico e a sua inovadora fórmula para explicar a formação dos preços no mercado; a perfeita mobilidade entre os fatores produtivos dentro das empresas e entre as empresas (por exemplo: trabalhadores qualificados podem ser contratados imediatamente no mercado, sem que exista qualquer custo de aprendizado para eles) e a assunção de que todos os produtos competiriam de forma similar no mercado, ou seja, haveria uma homogeneidade do produto, que daria sentido a um único tipo de concorrência, baseada no preço do bem adquirido ${ }^{43-44}$.

A forte interação entre os conceitos econômicos e os jurídicos passou a ser uma das características da Escola de Chicago. Ao longo do tempo, a influência foi fortalecida, especialmente com a incorporação de dois importantes conceitos: a busca pela eficiência econômica e a utilização da Análise Econômica do Direito para a tomada de decisões ${ }^{45}$.

A eficiência econômica, entendida como a possibilidade do agente produzir os bens a custos menores, passou a ser o Norte da Escola de Chicago para a formulação da política concorrencial e para a aplicação do direito. Para sua verificação, utiliza-se a fórmula desenvolvida por VILFREDO PARETO no início do século XX: ela seria alcançada

434 "O custo marginal é o custo adicional no qual uma empresa incorre ao produzir uma unidade a mais de produto. Por exemplo, uma das 30 produtoras de macarrão de uma determinada região produz 1.000 pacotes de $500 \mathrm{~g}$ por semana, que são vendidos a $\mathrm{R} \$ 2,00$ cada um. Ela tende a aumentar sua produção na medida em que possa fazê-lo por um custo inferior custo inferior a $\mathrm{R} \$ 2,00$ por pacote. Se, em razão de seus custos totais de produção (capacidade de equipamentos, falta de suprimento de matérias-primas na região, horas extras de funcionários etc.), a produção do milésimo primeiro pacote custar $\mathrm{R} \$ 2,05$ a empresa terá prejuízo ao fabricá-lo". (ANA MARIA NUSDEO, op. cit., p. 33). Sobre a Nova Economia Subjetivistamarginalista: "Os marginalistas vieram sustentar que, não podendo entender-se o preço como função da soma de utilidades, ele é função do aumento de utilidade, da utilidade adicional oferecida ao consumidor pela unidade marginal de uma oferta dada. Este aumento de utilidade (o grau final de utilidade, de que fala Yevons, ou a utilidade marginal, na designação de Marshall) é que determina o valor. Esta idéia é expressa com clareza por Yevons: 'O valor depende unicamente do grau final de utilidade. Como poderemos variar este grau de utilidade? Tendo maior ou menor quantidade de mercadorias a consumir. E como obteremos maior ou menor quantidade de mercadorias? Despendendo mais ou menos trabalho para se obter a sua oferta. Segundo este modo de ver, há dois intermediários entre o trabalho e o valor. O trabalho determina a oferta e a oferta determina o grau de utilidade, que comanda o valor ou a relação de troca. [...] O trabalho determina o valor, mas só de modo indirecto, ao variar o grau de utilidade das mercadorias por meio de um aumento ou limitação da oferta"” (ANTÓNIO JOSÉ AVELÃS NUNES, op. cit., p. 541).

$44 \quad$ A esse respeito, considerar o modelo simplificado de mercado explicado na nota número 85 e as observações sobre a concorrência schumpeteriana.

45 Ao tratarmos do Direito como técnica de decisão, necessária é a referência à obra Introdução ao estudo do direito: técnica, decisão, dominação, de TERCIO SAMPAIO FERRAZ JÚNIOR, op. cit., na qual o autor explica que a ciência dogmática do Direito tem o direito posto como técnica para a solução dos conflitos. 
quando não houvesse qualquer outra alternativa que fosse preferível a um consumidor sem trazer prejuízo a outro. Ou seja, as trocas no mercado deveriam ocorrer sucessivamente até que uma delas causasse prejuízo a um dos agentes. Nesse momento, elas seriam interrompidas e os recursos teriam encontrado a melhor alocação possível. O "ótimo de Pareto" é atingido quando todas as empresas, em determinado momento histórico, produzem exatamente a quantidade de produtos que é demandada pelos consumidores (há um equilíbrio entre a produção e a demanda) ${ }^{46}$.

A Análise Econômica do Direito (conhecida como Law and Economics) utiliza a eficiência econômica como técnica para a resolução dos conflitos, mas com uma especificidade: o parâmetro para a eficiência econômica não é a fórmula de PARETO, mas sim o critério KALDOR-HICKS (ou eficiência potencial de Pareto). A opção se justifica porque raramente encontramos no mercado situações nas quais os dois agentes são beneficiados pelas trocas entre eles (conforme supõe a fórmula de Pareto). Assim, para uma análise mais calcada na realidade, passou-se a admitir como eficientes as hipóteses nas quais os ganhos percebidos por um dos agentes compensassem as perdas sofridas por sua contraparte ${ }^{47}$.

Essas visões da Escola de Chicago trouxeram profundas transformações ao direito concorrencial, especialmente pela contestação a antigos dogmas. Um bom exemplo disso está na alteração do entendimento sobre a concentração de mercado: se antes se acreditava que eram prejudiciais à concorrência (conforme verificamos dos ensinamentos da Escola Estruturalista de Harvard), os estudos econômicos trazidos por Chicago passaram a afirmar que os grandes players traziam consigo uma melhor alocação dos recursos no mercado, representada pela possibilidade de economias de escala e escopo (nesse sentido, consultar

46 Quando o ótimo de Pareto não é atingido, ou o mercado produz mais bens do que o necessário ou, ao contrário, a oferta é menor do que a necessária. Com essa distribuição ineficiente, a sociedade como um todo é prejudicada, pois perde parte de sua riqueza, o que se convencionou chamar, nas análises econômicas, de deadweight loss.

47 Com efeito, é realmente muito difícil que ambas as partes sempre se beneficiem do intercâmbio. No caso de medidas tomadas pelo governo, por exemplo, podemos supor que a reserva de mercado para a indústria nacional possa ser prejudicial para o consumidor que paga mais caro pelo bem hoje, mas poderá ser benéfica amanhã para o consumidor que poderá contar com mais de um fornecedor no mercado. 
Capítulo 3). Ou seja, o que antes era tipo como potencial ilegalidade, passou a ser percebido como sinal de maior eficiência ${ }^{48}$.

Com a crescente influência alcançada, fusões, aquisições e condutas passaram a ser analisadas tendo como foco a eficiência produtiva que essas estruturas teriam no mercado: quanto mais tendessem à produção abaixo do custo, mais seriam benquistas pela teoria econômica e, por conseqüência, deveriam ser suportadas pela disciplina antitruste. Observaremos no Capítulo 8 que, nos termos da legislação brasileira, as eficiências associadas às grandes corporações podem ser um fator a justificar a realização de um ato de concentração do qual poderiam advir efeitos não concorrenciais.

Esse é um ponto que pode trazer uma argumentação favorável para a utilização dos cartéis de exportação. Verificaremos ao longo do trabalho que eles são formas de tornar a atividade dos exportadores mais racional, diluindo custos $\mathrm{e}$ trazendo maior competitividade. Nesse sentido, podem levar a uma melhor alocação de recursos, o que justificaria, para a Escola de Chicago, a sua existência.

Por outro lado, a Escola de Chicago apresenta uma série de fundamentos que podem ser visceralmente contrários à existência dos cartéis de exportação. Vamos nos aprofundar um pouco mais nesses aspectos.

O primeiro deles, sem dúvida, trata da defesa do livre mercado. Como se observou, as correntes clássicas afirmam que a atuação desimpedida dos agentes seria a melhor forma de alocação dos recursos na sociedade. Disso resulta a idéia de que os entraves ao livre intercâmbio entre eles deveriam ser evitados, em prol de um fluxo "natural" entre eles. É certo que tal entendimento se estende para o comércio externo, ou seja, que também o

48 "Evidentemente, o paradigma da estrutura-conduta-desempenho foi alvo de duras críticas, principalmente da chamada Escola de Chicago, que questionava a presunção de mau desempenho dos mercados a partir da verificação exclusivamente da sua estrutura. Mais exatamente, sua divergência relacionava-se à desconsideração da existência de economias de escala, da forma de cálculo da lucratividade, bem como da pressuposição de que altas taxas de retorno de investimentos fossem sinal inequívoco de falta de concorrência, e, finalmente, ao açodamento das Cortes e das autoridades antitruste na repressão de práticas alegadamente anticoncorrenciais, sem atenção aos possíveis efeitos pró-concorrenciais" (ANA MARIA NUSDEO, op. cit., p. 43). No mesmo sentido, PAULA A. FORGIONI: "Os pressupostos teóricos da Escola de Chicago acabam por modificar a aplicação da Lei Antitruste. Não há razão para impedir um comportamento (ainda que prejudicial ao consumidor ou outros concorrentes), se não for demonstrado que a prática produz, também, um efeito distorsivo sobre a alocação dos recursos e, consequentemente, sobre o bem estar geral da economia. Muitas práticas que eram tradicionalmente consideradas ilícitas, porque prejudiciais à concorrência (ilícitas per se), passaram a ser consideradas apenas ilícitas in se, na medida em que asseguram economias de produção" (Os fundamentos do Antitruste, cit., p. 173). 
intercâmbio entre os países deve ocorrer sem qualquer mecanismo que possa alterar suas condições normais. Como teremos a oportunidade de verificar ao longo desse estudo, essas idéias, genericamente denominadas de "liberais" ganharam eco ao longo das décadas de 1980 e 1990, trazendo profundas marcas para as economias mundiais.

Para a análise que nos interessa, acreditamos que a utilização dos cartéis de exportação seria seriamente ameaçada por esses ideais. Isso porque as associações para exportação poderiam ser entendidas como mecanismos "não naturais" de alteração das condições normais de concorrência e de livre mercado, trazendo vantagens competitivas indevidas aos agentes que se beneficiam da sua estrutura.

O segundo conceito da Escola de Chicago que poderia trazer empecilhos aos cartéis de exportação é o de não intervenção do Estado na economia. Esse é um ponto bastante delicado da teoria neoclássica, uma vez que acreditamos ser o Estado, por excelência, o promotor de políticas para promover alterações econômicas, sociais e de desenvolvimento nos países. A tentativa de dissociá-lo do mercado, impondo-lhe um comportamento passivo diante da economia é cercada de controvérsia, como observaremos no Capítulo $6{ }^{49}$. Fato é que os clássicos, assim como a Escola de Chicago reservam ao Estado uma atuação bastante pontual, unicamente quando da observância das chamadas falhas de mercado. Essas situações correspondem àquelas nas quais o mercado deixaria de ser um mecanismo competente para a coordenação dos fatores de produção e da alocação de recursos sendo, portanto, necessária a ação corretiva para que ele possa se restabelecer ${ }^{50}$. Em quaisquer

$49 \quad$ Apenas a título de exemplo sobre as discussões existentes sobre o papel do Estado, nos afirma LUIZ CARLOS BRESSER-PEREIRA: "No bojo da onda ideológica neoliberal que sacudiu o mundo desde os anos 1970, pretendeu-se opor o Estado ao mercado no processo de desenvolvimento econômico. Esta oposição, entretanto, não faz sentido. O Estado é a instituição matriz das demais instituições formais de uma sociedade; e nas sociedades modernas, é o instrumento de ação coletiva por excelência da sociedade na consecução de seus objetivos políticos de segurança, liberdade, bem-estar, justiça social e proteção do ambiente. Nesta qualidade, um dos papéis do Estado é o de regular o mecanismo coordenador das economias capitalistas - o mercado. Não faz sentido, portanto, opor Estado a mercado" (Desenvolvimento econômico e revolução capitalista, cit., p. 2-3).

50 As falhas de mercado tradicionais são as externalidades, os bens públicos, a assimetria de informação, o poder de mercado, as estruturas de mercado ou condutas não competitivas, os direitos de propriedade, a diferença nas taxas de preferência por investimentos de curto e longo prazo, entre outros. Nas palavras de FABIO NUSDEO: "a falta de mobilidade de fatores que geram as crises de super ou sub produção; o deficiente acesso a todas as informações relevantes pelos agentes econômicos que falseia as suas decisões; a concentração empresarial derivada do fenômeno das economias de escala que elimina o jogo concorrencial por aniquilar a estrutura mercantil; os efeitos externos da atividade econômica produzindo custos e benefícios sociais - as externalidades - que se quedam incompensados e, assim, deixam de sinalizar adequadamente a escassez; a impossibilidade de captar as necessidades da comunidade por bens de caráter coletivo, isto é, aqueles que atendem concomitantemente às necessidades de um número razoavelmente grande de pessoas" (Fundamentos para uma codificação do Direito Econômico, cit., p. 23). 
outras situações, afirmam seus teóricos, os custos da intervenção estatal seriam muito superiores aos benefícios que seriam encontrados - atuação, deixe-se claro, é recomendada unicamente para proteger o mercado ${ }^{51}$.

Assim resume PAULA A. FORGIONI: "O objetivo da atuação estatal é, assim, claro e determinado: eliminar (ou reduzir) essas falhas, para que se tenha como resultado o melhor grau de eficiência alocativa possível, ou seja, logra-se obter um ambiente econômico como se falhas não houvesse. Em outras palavras, a neutralização das falhas que se dá pela intervenção visa apenas estimular o funcionamento de um mercado concorrencial" 52 .

A consequência da falta de qualquer atuação do Estado na economia poderia ser desastrosa para os cartéis de exportação. Isso porque eles dependem de uma autorização (ou, ao menos, de uma atitude passiva) para que possam existir (neste sentido, confrontar Capítulo 4). Dessa maneira, se aos Estados não for dada a possibilidade de amoldar as suas políticas concorrenciais e econômicas no sentido de viabilizar a utilização desses instrumentos, acreditamos ser remota a possibilidade de êxito no seu emprego.

Há ainda uma última problemática trazida pelos ensinamentos da Escola de Chicago e ela interessa não apenas aos cartéis de exportação, mas a toda a sistemática de aplicação do direito. Com efeito, a utilização não criteriosa dos ensinamentos por ela trazidos pode levar a uma inversão de valores, na qual são as regras e objetivos econômicos que traçam os rumos do direito. Nas palavras de CALIXTO SALOMÃO FILHO: “A análise econômica do Direito tem uma cartilha própria de interpretação e conformação da realidade econômico-social, que, como sabido, dá prevalência absoluta à fixação de objetivos econômicos, submetendo o Direito a esses objetivos" ${ }^{\text {"53. }}$

51 Sobre a evolução dos acontecimentos que levaram à busca pelo Estado mínimo, consultar a obra de FABIO NUSDEO: "Procurava-se, em suma, ante a impossibilidade da completa separação dos planos de decisão, econômico e político, fazer com que as intersecções entre ambos fossem reduzidas a áreas restritas e de localização muito específica, nomeadamente aquelas com relação às quais o mecanismo de mercado se revelasse decididamente inoperante. A isso passou-se a chamar-se posteriormente de Estado mínimo [...]" (Fundamentos para uma codificação do Direito Econômico, cit., p. 12).

Análise Econômica do Direito (AED): Paranóia ou Mistificação?, In Revista de Direito Mercantil, industrial, econômico e financeiro, n. 139, jul-set 2005, p. 246.

5

CALIXTO SALOMÃO FILHO, Direito concorrencial - as condutas, cit., p. 14. 
E isso ocorre porque a Escola de Chicago foi capaz de trazer para o direito um “objetivismo" que não lhe é característico. Explica-se: o direito é uma ciência valorativa ${ }^{54}$. Ao se encaixar no ramo das ciências humanas, está sujeito a influências das mais variadas, como as sociais, as políticas e as econômicas. Ao contrário das ciências exatas, o direito não possui respostas precisas, muito ao contrário, elas podem ser antagônicas tendo em vista serem, ao longo do tempo, temperadas pelos princípios gerais do direito, pela hermenêutica dos Tribunais Superiores e pelas influências do ambiente em que se vive. A diversidade traz o benefício de decisões tomadas levando em conta as especificidades de cada caso concreto, mas traz também um custo, que é o da maior insegurança e imprevisibilidade.

A tendência do ser humano, no entanto, é a de preferir situações de maior conforto. Especialmente em ambientes negociais, optam por cenários mais precisos e conhecidos no qual uma mesma pergunta leva necessariamente a uma mesma resposta ${ }^{55}$. A característica de ciência inexata e valorativa do Direito não é, portanto, apreciada por esses agentes. Nesse contexto, a proposta da Escola de Chicago de resolver séculos de discussão com a simples aplicação de teorias econômicas é, sem sombra de dúvidas, bastante sedutora ${ }^{56}$. Questões e decisões complexas e que causavam tormento a muitos estudiosos, como o conceito de justiça, equidade e liberdade, foram subitamente relegados a segundo plano, afastados da discussão por comprometerem a segurança jurídica ${ }^{57}$.

$54 \quad$ "Postular que o conhecimento é valorativo não é nada mais, nada menos, que afirmar que os valores de determinada sociedade podem influenciar - e influenciam - de maneira determinante o conhecimento que se tem dela. Se, como afirma a doutrina, não existe uma norma vazia sem uma pretensão ou um interesse a proteger - ou seja, sem um valor que lhe esteja por trás - então, a sociedade que conhecemos, ao cumprir essas regras, nada mais faz que traduzir esses valores" (CALIXTO SALOMÃO FILHO, Direito concorrencial - as condutas, cit., p. 43).

55 Aqui, é fundamental a contribuição da Nova Economia Institucional, demonstrando como as expectativas e o ambiente são capazes de diminuir os custos de transação. Nesse sentido, consultar a nota 132.

56 "De um lado, há a opinião de que o único objetivo da política de concorrência é maximizar a eficiência econômica. Segundo essa visão, não há espaço para critérios sociopolíticos, como a probidade e a equidade, na administração da política da concorrência. Tais critérios são considerados mal definidos e carregam juízos de valor subjetivos, não podendo, portanto, ser aplicados consistentemente". SHYAN KHEMANI (org.), op. cit., p. 30.

57 “A Escola de Chicago percebe, então, o antitruste em um ambiente asséptico, livre de conflitos de princípios ou de interesses presentes na aplicação de cada caso concreto. $\mathrm{O}$ discurso utilizado baseia-se no tecnicismo. Ou seja: as decisões a serem tomadas não derivariam de opções políticas, seriam racionais e neutras. No entanto, dizem os críticos, a falácia de tal argumento salta aos olhos, porque impossível separar os dois aspectos: toda técnica implementa uma opção política." (PAULA A. FORGIONI, Os fundamentos do Antitruste, cit., p. 177). 
Apesar de hoje observarmos o predomínio da aplicação dos ensinamentos da Escola de Chicago, especialmente nas cortes norte-americanas, é de se notar que ela é envolta em polêmicas. O problema não está na utilização de ferramentas matemáticas e econômicas na aplicação do direito, mas sim no seu emprego desarrazoado, sob a justificativa de que isso tornaria a aplicação do direito "isenta" (ou seja, sem qualquer juízo de valor) e mais objetiva. Quando confrontarmos esses ensinamentos com o texto da nossa Constituição Federal no Capítulo 7, perceberemos que em certos momentos é notória a opção do legislador por um Estado atuante e que visa a outros objetivos, que não apenas o livre mercado e a eficiência econômica.

\subsection{Observações sobre proteção aos consumidores ${ }^{58}$}

É comum associar a aplicação do direito concorrencial à busca pelo bem-estar do consumidor $^{59}$. Como se observou linhas acima, a Escola de Chicago tem como finalidade para o direito a busca pela melhor alocação da riqueza no mercado, mas não traz uma definição clara de quem seriam os destinatários dessas vantagens.

Os consumidores foram então galgados à condição de beneficiários ${ }^{60}$, sob o argumento de que a lógica de mercado e a racionalidade dos produtores fariam com que os excedentes por eles conquistados com a máxima eficiência fossem obrigatoriamente divididos com os consumidores, o que se daria por meio da diminuição dos preços praticados no mercado ${ }^{61}$. A crítica a essa ligação "tão direta" entre eficiência e redução de

58 Conforme nos explica CALIXTO SALOMÃO FILHO, a busca da proteção do consumidor está na gênese do Direito antitruste brasileiro, nos dispositivos constitucionais de proteção à economia popular (Direito concorrencial - as condutas, cit., p. 107).

$59 \quad$ Nesse sentido, JOSÉ MARCELO MARTINS PROENÇA: "Dentre as diversas correntes doutrinárias a respeito da tecnologia das leis de defesa da concorrência, uma delas defende o bem-estar máximo do consumidor, que deve ser equiparado à eficiência econômica. Esta só existe quando os recursos são alocados de tal forma que nenhuma outra alocação possível poderia melhorar a situação de um consumidor sem que, simultaneamente, piorasse a situação do outro" (Título VII das formas de controle, Capítulo I - Do controle de atos e contratos, cit., p. 391).

60 Nas palavras de CALIXTO SALOMÃO FILHO: "A concepção de eficiência muda radicalmente ao longo do tempo. A concepção original neoclássica da eficiência centra-se na maximização da riqueza global da sociedade. [...]. Uma real definição dos consumidores como destinatários diretos das normas antitruste obviamente não pode restringir a tutela à proteção do interesse da maximização da riqueza total, independentemente de quem deva ser seu destinatário" (Direito concorrencial - as condutas, cit., p. 144).

61 DANIEL GOLDBERG trata da defesa do consumidor: "Qualquer critério ao qual se atribua significação normativa independentemente do bem-estar implicará sacrifícios de todos os envolvidos. Uma 
preços é realizada por CALIXTO SALOMÃO FILHO: “[...] basta observar que, para os economistas neoclássicos, eficiência é a habilidade de produzir a custos menores e, consequentemente, reduzir os preços ao consumidor. Essa última constitui, sem dúvida, a passagem mais artificial dessa teoria. Da redução dos custos é derivada imediatamente a redução dos preços. A eficiência é associada diretamente ao bem-estar do consumidor. O único princípio norteador do direito antitruste passa, então, a ser a proteção do bem-estar do consumidor, no sentido específico definido pelos economistas neoclássicos [...]. A distribuição equitativa dos benefícios ao consumidor é presumida, derivando, necessariamente, da 'racionalidade' monopolista" 62 .

Analisada essa primeira questão, temos ainda uma outra. A Constituição Federal Brasileira, em seu artigo 170, dispõe que a defesa do consumidor é um dos princípios da ordem econômica. Mas, afinal, de que proteção estamos falando? A Escola de Chicago e as correntes clássicas nos apresentam um conceito de bem-estar do consumidor bastante estreito, ligado unicamente à redução de preços. Essa proposta simplificadora se adequa ao modelo de concorrência perfeita utilizado por seus economistas (a esse respeito, consultar o Capítulo 3), mas não permite qualquer investigação sobre os fatores que realmente lhe trazem esse bem-estar.

Pensando-se de maneira mais ampla, poderíamos supor que os consumidores poderiam obtê-lo de outras fontes, como da tecnologia, do design, da maior diversidade de produtos, da melhor localização das lojas, ou simplesmente da sua liberdade de escolha. Um outro problema enfrentado pelas teorias clássicas está na forma pela qual mensuram o bem-estar do consumidor e o comparam com o de outro. Certamente, esse procedimento é dotado de simplificação tal que pode mascarar seus reais resultados.

Uma ampliação no conceito de bem-estar do consumidor pode ser benéfica para uma análise positiva dos cartéis de exportação. Afirmamos linhas acima que é grande a possibilidade de trazerem eficiências ao mercado, tendo em vista o fato de permitirem a diluição de custos dos exportadores, o que poderia realmente levar a uma diminuição dos preços praticados. Por outro lado, não é de se esquecer que as associações para exportação,

solução vista como 'justa' que piore a situação de todos (medida em termos de bem-estar) deve ser vista como eticamente inferior a arranjos alternativos incrementais. Este é o credo que subscrevem os welfaristas $\mathrm{e}$ também o autor deste trabalho." (Op. cit., p. 57). 
ao agregarem mais um player à disputa concorrencial podem trazer outros benefícios, como a maior possibilidade de escolha ou o oferecimento de produtos diferenciados.

\subsection{A Escola de Freiburg}

Segundo CALIXTO SALOMÃO FILHO, o grande questionamento à Escola de Chicago foi realizado pela Escola de Freiburg (também chamada de ordo-liberal), surgida na Alemanha após os fracassos econômicos da República de Weimar e a ascensão do Nazismo.

A escola alemã contestou a aplicação indistinta dos pressupostos neoclássicos ao direito antitruste. As principais divergências estavam na definição dada ao conceito de bem-estar do consumidor (conforme discussão acima) e na própria forma como o conceito de concorrência era desenvolvido.

Ao contrário da Escola de Chicago, que pregava a busca incessante pela eficiência econômica, os militantes de Freiburg não acreditavam que pudesse ser atribuído qualquer objetivo a priori ao direito antitruste. Deveria ser garantida a possibilidade de escolha aos consumidores, ainda que ela fosse potencial - a concorrência teria como função assegurar aos agentes a descoberta das opções que se apresentam a eles. No resumo de CALIXTO SALOMÃO: "Para seus representantes a garantia da competição é fundamento essencial para a garantia do funcionamento econômico de uma economia de mercado. A organização ideal da ordem privada é aquela que permita a 'autocoordenação' e o 'autocontrole'. O direito deve criar as condições para que ambas as garantias se efetivem: a 'autocoordenação' é garantida por meio das transações privadas, para as quais o direito de propriedade e o direito das obrigações são elementos organizativos fundamentais. Já a segunda ordem, 'autocontrole', 'becomes effective as soon as the potential partners to a transaction have moved into a position which allows to assess the conditions of an exchange in view of the possibility of substituting partners to (and objects of) a transaction' [...]. É esse tipo de preocupação - a possibilidade de efetiva competição - que deve ter guarida no direito concorrencial" ${ }^{\prime 63}$.

63 Direito concorrencial - as estruturas, cit., p. 26. 
Frise-se, por importante, que a busca pelo livre mercado é bastante diversa da busca pela concorrência. A primeira pressupõe que as empresas atuem livremente, sem qualquer atuação do Estado, exceto a de evitar a ocorrência das falhas de mercado. Nesse cenário, o jogo das forças concorrenciais pode levar à existência de uma única empresa a oferecer determinado produto, ou seja, a presença de um monopolista, visto o agente ser mais eficiente ou deter qualquer condição que lhe permita expulsar os demais players do mercado. Em uma situação como essa, o consumidor pode ser afetado, ficando acorrentando a um único fornecedor ${ }^{64}$.

A proteção à concorrência, por outro lado, pressupõe a existência de um mercado que beneficie o consumidor, na medida em que a saudável disputa entre as empresas tende a levar a menores preços, busca por inovação e melhorias nos produtos e serviços. Não há dúvidas de que a atuação dessas empresas no mercado será marcada pelos efeitos das regras do livre mercado - ocorre que, nesse caso, o Estado poderá operar no sentido de manter vivas as condições de competição, na medida em que elas revertam em benefícios diretos para os consumidores.

É importante atentar para o fato de que a Escola de Freiburg se preocupa com a existência de concorrência potencial no mercado, ou seja, para que ela seja contabilizada, não precisa ser efetiva. Nesse ponto, é necessário se estudar as barreiras de entrada que existem em determinado mercado. Se a entrada for simples, não demandar altos investimentos e puder ser realizada a qualquer momento, não deveria haver preocupação concorrencial, visto que as altas taxas de retorno obtidas pelas empresas certamente servirão de atrativo para a entrada de novos agentes na arena concorrencial. Em um tal mercado, concentrado mas com baixas barreiras à entrada, não seria justificável a atuação do Estado na economia, independentemente do seu nível de concentração.

A Escola de Freiburg não parece trazer empecilhos para a utilização dos cartéis de exportação. Dentro de nossa percepção, ao contrário, poderiam até ser aceitos no mercado com altas barreiras à entrada pois disponibilizam no cenário internacional mais um competidor que poderá trazer maiores oportunidades de escolha para os consumidores. 


\subsection{Outras formas de entendimento da matéria}

Verificamos até o momento os objetivos eleitos por cada uma das principais Escolas para o direito concorrencial. Não podemos deixar de mencionar, entretanto, uma outra linha de pensamento, de grande valia para este estudo, segundo a qual discussões em abstrato sobre os objetivos do direito concorrencial não fariam sentido.

Isso porque uma definição eficaz deve ser necessariamente feita tendo em vista uma série de fatores, dentre os quais certamente encontraríamos a realidade social, econômica e política do país, seu nível de desenvolvimento e o seu ordenamento jurídico. Note-se que todos esses elementos podem ser alterados ao longo do tempo, o que demanda que os objetivos sejam constantemente adaptados à realidade que os circunda ${ }^{65}$. Por esse entendimento, a política concorrencial e a aplicação do direito antitruste são instrumento do qual o Estado dispõe (junto com muitos outros) para a consecução de seus objetivos ${ }^{66}$ no caso brasileiro, um ferramental para que se possa dar cumprimento aos preceitos estabelecidos na Constituição Federal de 1988.

PAULA A. FORGIONI afirma: “A Lei Antitruste desempenhará, em determinados sistemas jurídicos e momento histórico, função diversa daquela desempenhada em outros sistemas, em outros momentos. É fácil perceber, portanto, que as discussões excessivamente gerais sobre os objetivos da Lei Antitruste sem que seja determinada a lei e o momento de que se trata, são de certa maneira, estéreis" ${ }^{\text {67. }}$.

Essa forma de compreensão da lei concorrencial certamente é bastante diversa das anteriormente analisadas, especialmente da visão "matemática" oferecida pela Escola de Chicago. O distanciamento, certamente, não significa o desprezo pelo seu ferramental, mas indica que, para o sistema brasileiro, não é cabível falarmos em um conjunto de normas que não esteja em linha com o disposto no texto constitucional (a esse respeito, verificar acima), ou que se presta unicamente à busca da eficiência econômica, isolada do resto do ordenamento.

65 Uma discussão mais aprofundada sobre quais seriam as políticas publicas a que visam o direito concorrencial pode ser encontrada na obra de DANIEL GOLDBERG, Op. cit..

66 Indispensável para a compreensão dessa perspectiva de análise a leitura das obras de EROS ROBERTO GRAU e PAULA A. FORGIONI.

67

Os fundamentos do Antitruste, cit., p. 163-164. 
Seria realmente bastante estranho que os teóricos da Escola de Chicago pudessem, tendo como base a realidade e as leis americanas da década de 1970, formular objetivos para a aplicação do direito antitruste que pudessem ser usados em todo o globo, ao longo de todas essas décadas. Obviamente, uma concepção como essa deve necessariamente adotar duas premissas, anteriormente discutidas: a primeira a de que as leis econômicas são imutáveis e, como leis naturais, se prestam à explicação de qualquer fenômeno. A segunda a de que o direito antitruste se prestaria unicamente para a correção de falhas de mercado e, dessa forma, não seria necessária sua adequação a novas realidades políticas, econômicas e sociais.

Ao se optar por uma atitude passiva do Estado, como a pleiteada pelos clássicos, o direito antitruste restaria engessado, impedido de ser utilizado para outras finalidades, o que pode ser inadequado, tendo em vista a já mencionada proximidade do direito antitruste com outras áreas, como a política industrial e o comércio internacional, que abre portas para que a disciplina amplie o seu espaço de atuação, não ficando restrita unicamente ao estudo da dinâmica concorrencial em determinado mercado.

Isso não significa, certamente, que o as políticas concorrenciais não possam procurar a eficiência como um de seus objetivos. Muito ao contrário, a eficiência e a competição, pelos benefícios já apontados pelos economistas, devem sempre estar presentes na análise da autoridade antitruste. Entretanto, o nível de concorrência a ser buscado não deve ser necessariamente o mais alto possível, mas sim aquele adequado para determinado país, tendo em vista o seu nível de desenvolvimento. Teremos a oportunidade de observar no Capítulo 3 que a coordenação dos agentes pode ser bastante interessante em determinadas situações.

A crítica que ora se realiza está na eleição a priori de uma única meta a ser perseguida independentemente das especificidades de cada país. Com efeito, sociedades que desfrutam de bons níveis de riqueza e de distribuição de renda podem ser ambientes propícios para que se adotem objetivos mais "individualistas" para as normas concorrenciais, conforme pleiteado pela Escola de Chicago. Nesses locais, os agentes econômicos certamente estarão mais aptos a isoladamente realizarem trocas mais proveitosas para ambas as partes. Em países nos quais essa não é a realidade, é difícil pensarmos na aplicação isolada da noção de eficiência, fortemente alicerçada em conceitos particularistas e na racionalidade dos agentes para a tomada de decisões. Em países ditos 
em desenvolvimento, a norma antitruste é um importante instrumento do qual dispõe as autoridades para a busca de interesses como o crescimento sustentável de longo prazo e o desenvolvimento econômico e social de sua população. Dessa forma, devem ser livres para formularem as suas próprias análises e estudos sobre a melhor forma de aplicação do direito, não estando presos a evidências e experiências formatadas para outras realidades.

A história brasileira é repleta de exemplos de diferentes aplicações conferidas ao direito concorrencial. De acordo com o período histórico, já se falou em defesa da economia popular ou em defesa da livre concorrência. Em certas ocasiões, foram aprovados atos de concentração com objetivo de estimular as empresas nacionais que, possivelmente, hoje seriam julgados de forma diversa. Veremos no Capítulo 8 que aqui não há que se falar em arbitrariedade, ou em falta de segurança e de previsibilidade (que, como se viu acima, são caras aos aplicadores da Análise Econômica do Direito), mas apenas na comprovação de que não há, na aplicação desse ramo do direito, um objetivo único, estabelecido a priori. Ao contrário, dependendo do momento que se analisa, mais de um objetivo poderá ser juridicamente aceito.

Nesse sentido, observa FÁBIO NUSDEO: “A tutela da concorrência e a repressão aos abusos do poder econômico são objetivos de caráter múltiplo, inseridos no próprio conjunto da política econômica de cada país, com a qual devem guardar uma necessária coerência. É por esse motivo que se tem observado, ao longo da história econômica dos vários países, posição e atitudes diversas frente aos mesmos. Tal diversidade tem refletido menos diferenças de cunho doutrinário e ideológico e muito mais as preocupações com as metas assinadas para a economia de cada país em determinados momentos históricos"68.

Pensando sobre os tipos de objetivos que podem ser eleitos para o direito concorrencial, podemos enumerar os seguintes ${ }^{69}$ :

68 Enciclopédia Saraiva de Direito, vol. 2, p. 121.

69 SHIEBER identifica alguns dos interesses existentes na lei Antitruste: "Os benefícios econômicos que se espera da concorrência podem ser encarados sob vários aspectos. Primeiro, o aspecto que visa os interesses do consumidor, que goza, sob um regime em que prevalece a concorrência, de maior qualidade, menor preço, e um grande número de produtos entre os quais se possa escolher. Segundo, o aspecto que visa os interesses das empresas concorrentes, tanto as potenciais como as atuais. Estas gozam, num regime de concorrência, da liberdade de dedicar-se a um ramo de negócios e a crescer pelo mérito de seus atributos, sem sofrer entraves pelas ações conjuntas das empresas que já fazem parte do mercado ou pelas atividades de empresas dominantes. Finalmente, o aspecto que visa ao interesse da nação inteira no desenvolvimento econômico do país, que, sob regime de concorrência, goza de um parque industrial moderno que fortalece e 
i) a proteção a determinados grupos, como as pequenas empresas ou determinados setores da economia. Esse tipo de preocupação costuma ser bastante comum em países nos quais a indústria é incipiente ou pouco desenvolvida, nos quais é necessária a proteção contra a concorrência de transnacionais com grande poderio econômico ${ }^{70}$.

A proteção é usualmente utilizada para segmentos pouco desenvolvidos da economia, como, por exemplo, o farmacêutico, que, caso estivesse sujeito às condições normais de mercado, jamais teria condições de florescer e se tornar competitivo em face da concorrência de empresas mundiais. Como há interesse nacional de que esse setor cresça, tomam-se medidas para facilitar o seu desenvolvimento e para protegê-lo. O apoio inicial deverá se reverter, no futuro, em benefícios para o país, que poderá contar com uma indústria consolidada e de ponta dentro de seu território. Outra área na qual a proteção costuma ser aplicada é a agricultura. Os motivos para esse cuidado podem variar, passando pela idéia de que é estratégico manter a produção de alimentos dentro do próprio território até a necessidade de proteger determinadas comunidades especiais, que a ela se dedicam durante décadas ${ }^{71}$.

ii) a proteção do desenvolvimento econômico, a busca de fins nacionalistas ou protecionistas. Ao aplicar o direito, um país pode ter como fim a busca do desenvolvimento econômico, ou de fins determinados por sua política interna.

assegura ao povo os produtos que melhoram sua vida cotidiana" (Abusos do poder econômico: direito e experiência antitruste no Brasil e nos EUA, São Paulo, Revista dos Tribunais, 1966, p. 64).

70 A título de exemplo, EROS ROBERTO GRAU nos traz a proteção concedida pelo Estado americano aos produtores de motos contra as empresas japonesas na década de 1980 (A ordem econômica na Constituição de 1988, 6. ed., São Paulo, Malheiros, 2000, p. 34).

71 "Indeed, special exemptions of the agricultural sector from full application of competition rules can be found in many jurisdictions. Most developed countries consider agriculture as a special sector of the economy requiring intensive intervention by means of regulation, such as quota systems, price support mechanisms and protection from imports. These policies are felt strongly in the international trade arena, where agriculture has always been considered - at least by the developed countries - as a 'special case' not amenable to the regular liberal trade rules [...]. Economic, as well as non-economic rationales (such as the need to preserve rural communities), are claimed to preclude regulation of the agricultural sector by means of market mechanisms, and to mandate government regulation of this sector. [...]. In the United States (U.S.), the special exemption for the agricultural sector was enacted as early as in 1922 - the Capper-Volstead Act. In the European Community (EC), the exemption is included in the Treaty Establishing the EC, in article 36 (ex article 42), ever since its inception in 1957" (ARIE REICH, The agricultural exemption in antitrust law: a comparative look at the political economy of market regulation, In Texas Internatonal Law Journal, vol. 42,n. 848, 2007, p. 844). 
Essa última forma de interpretação das normas concorrenciais é, sem dúvida, aquele que confere maior viabilidade para a utilização dos cartéis de exportação. Com efeito, ao se empreender uma visão mais ampla do direito antitruste, analisando-o conjuntamente com as políticas públicas e os objetivos traçados constitucionalmente, torna-se mais palpável a autorização para que ocorra uma possível restrição ao livre comércio ou à livre concorrência em prol do atingimento de outros objetivos, como os acima analisados.

Por tudo o quanto se discutiu até o momento, resta claro que, ao longo desse estudo, adotaremos a concepção do direito concorrencial como implementador de políticas públicas. Justificamos a escolha dessa alternativa por não considerarmos possível, dentro de nosso ordenamento, a existência autônoma de qualquer ramo do direito sem a sua devida harmonização com os princípios, objetivos e fundamentos trazidos pela Constituição Federal.

Encerraremos essa parte do estudo com as palavras de FABIO NUSDEO: "Aberto o caminho para a sua entrada no sistema (do direito concorrencial), passa gradualmente a assumir um segundo papel, dentro do qual marca presença ao impor finalidades outras que não a de mero suprimento de condições para superar as imperfeições anteriormente apontadas. Trata-se, agora, de lograr a obtenção de objetivos de política econômica bem definidos para o desempenho do mesmo sistema, o que implica, em última análise, imporlhe distorções, alterá-lo, interferir no seu funcionamento, a fim de fazer com que os resultados produzidos deixem de ser apenas os naturais ou espontâneos, para se afeiçoarem às metas fixadas"

72 E continua: "Esse, estritamente falando, o campo da política econômica, no qual as variáveis identificadoras do sistema são vistas segundo a ótica de que algumas constituem meios ou instrumentos para que outras, tidas como fins, se materializem ou assumam valores previamente determinados. Mas, quais seriam essas variáveis vistas como meios ou instrumentos? Em geral, aquelas mesmas corresponderes à outra ordem de ação estatal: a destinada a coadjuvar o mercado para levá-lo à superação de algumas de suas disfunções. Assim, os tributos, voltados, em princípio, a custear a máquina oficial e o suprimento de bens coletivos, serão agravados, atenuados ou até mesmo anulados, conforme tais medidas se revelem instrumentais para a consecução dos fins ou objetivos da política econômica. O mesmo se diga dos instrumentos monetários, cambiais e os institucionais ligados à regulamentação econômica no sentido anteriormente discutido" (Fundamentos para uma codificação do Direito Econômico, cit., p. 25-26). 


\section{OS CARTÉIS}

Este Capítulo tem o objetivo de introduzir a discussão sobre os cartéis. Em especial, pretendemos estudar a forma como os cartéis clássicos ${ }^{73}$ atuam no mercado e a motivação das autoridades antitruste para a sua coibição. Ademais, procuraremos evidenciar a necessária distinção entre eles e outros tipos de acordos entre concorrentes, como, por exemplo, os cartéis de exportação.

Os cartéis são a espécie mais conhecida do gênero colusão horizontal, definidas por CALIXTO SALOMÃO FILHO como "qualquer tipo de acordo, expresso ou tácito, firmado entre concorrentes" ${ }^{\natural 4}$. Nessa categoria também estão incluídas as joint ventures, as atividades de associações de classe, entre outras ${ }^{75}$.

As colusões horizontais são objeto de atenção das autoridades concorrenciais, pois se acredita que a atividade conjunta de concorrentes pode trazer malefícios ao mercado e aos consumidores. Não faltam exemplos de ação concertada para o aumento dos preços no

73 Utilizaremos o termo "cartéis tradicionais" e "cartéis clássicos' como sinônimo de hard core cartels do direito americano. Estes últimos são assim definidos pela International Competition Network: "A first building block in the fight against cartels is the clear identification of prohibited behavior - conduct that is considered hard core cartel conduct. A clear delineation of such conduct provides guidance to the business community subject to the law and distinguishes hard core cartel behavior for the purposes of punishment and deterrence as compared to less pernicious violations. The recent increased cooperation among antitrust agencies in anti-cartel enforcement has enabled significant international convergence on cartel policy issues. Given the shared commitment to fighting cartels, Subgroup 1 explored the starting point for anti-cartel enforcement in various jurisdictions - the definition of a hard core cartel. The basic concepts of a cartel found in statutes and policy statements are nearly universal: a cartel is defined as an agreement between competitors to restrict competition. Further, the categories of conduct most often defined as 'hard core' are also consistent: they are price fixing, output restrictions, market allocation, and bid rigging" (INTERNATIONAL COMPETITION NETWORK, Defining hard core cartels conduct, ICN, 4th Annual Conference, Bonn, 6-8 June, 2005).

74 CALIXTO SALOMÃO FILHO, Direito concorrencial - as condutas, cit., p. 262.

75 "O espectro de operações de cooperação empresarial é bastante amplo, incluindo mesmo as de caráter societário - e não contratual - limítrofes à configuração de hipótese de concentração econômica. Trata-se daquelas operações que criam entre as sociedades envolvidas uma influência relevante do ponto de vista concorrencial sem, no entanto, ir ao ponto de unificar o comando entre elas. A cooperação empresarial inclui ainda as chamadas joint ventures, ou consórcios de companhias para a realização de empreendimentos, cujos efeitos concorrenciais podem caracterizar situação de colaboração entre as participantes ou de verdadeira concentração. Essas características da cooperação empresarial - amplitude das possíveis operações pelas quais se manifesta e limites tênues com relação à concentração empresarial - explicam seu estudo juntamente com os atos de concentração" (ANA MARIA NUSDEO, op. cit., p. 55). 
mercado ou para a fraude em licitações públicas ${ }^{76}$. Mas a presunção de prejuízo não é absoluta $^{77}$. A coordenação dos agentes pode ser benéfica aos consumidores, à concorrência ou pode ser simplesmente ser uma forma de atuação autorizada pelo Estado.

Para analisarmos esse assunto, voltemos aos ensinamentos trazidos pela Escola de Chicago e pela Escola de Harvard, discutidos no Capítulo 2. Os desenvolvimentos econômicos evidenciaram o fato de que um grande inúmero de agentes atuando no mercado e a existência de uma estrutura pulverizada pode não ser o melhor arranjo concorrencial possível. A primeira justificativa para isto está no fato de serem remotas as hipóteses de existência e manutenção de um mercado perfeitamente competitivo, descritos abaixo. A segunda está no fato de inúmeros fatores econômicos justificarem a escolha pela coordenação entre agentes.

Um desses motivos são as chamadas economias de escala, que correspondem à diminuição do custo médio de confecção dos bens, resultado da maximização dos seus níveis produtivos. A redução pode estar relacionada à economias de escala reais, quando o valor dos insumos necessários para a produção não acompanha o número final produzido (ou seja, produz-se um maior número de bens com a utilização de um menor número de insumos) e a economias de escala pecuniárias, que, por sua vez, se dividem entre os ganhos de especialização (utilização de máquinas e mão-de-obra especializada); a indivisibilidade técnica (melhores taxas de aproveitamento das máquinas existentes na plantas industriais); as economias da lei dos grandes números (há a maximização da utilização da mão de obra em estruturas fabris maiores, ou seja, o mesmo número de funcionários seriam utilizados

\footnotetext{
76 Para exemplos de cartéis investigados no Brasil consultar os relatórios elaborados pela Secretaria de Direito Econômico, disponíveis em http://www.mj.gov.br/sde/main.asp?Team=\%7BDA2BE05D\%2D37BA\%2D4EF3\%2D8B55\%2D1EBF0EB 9E143\%7D, acesso em 10 out. 2009.

77 Para averiguar a possível conduta anticoncorrencial de um agente, é comum a realização de um estudo delimitando os efeitos do acordo no mercado e a forma pela qual foi ele desenvolvido. Perguntas comuns seriam as seguintes: "A restrição tem potencial inerente de limitar a produção ou elevar os preços? A restrição é flagrante ou está claramente relacionada a alguma integração pró-competitiva de recursos econômicos? A restrição limitará a produção ou elevará preços ou, sob outros aspectos viabilizará ou facilitará o exercício de poder de mercado? A restrição é necessária para se atingirem os objetivos prócompetitivos declarados? Os benefícios pró-competitivos da restrição superam seus riscos?" (SHYAN KHEMANI (org.), op. cit., p. 63).
} 
para manter uma planta de 500 ou de 700 metros quadrados); e as economias geométricas (relação entre o custo do capital e o tamanho das plantas industriais) ${ }^{78}$.

Como podemos inferir, a maximização dos níveis de produção pode depender de um grande volume de produção em determinada fábrica. Por consequiência, pequenas empresas, atuando isoladamente, não teriam condições de auferi-la. Nesse caso, há evidente vantagem na existência de players maiores ou na admissão da atividade conjunta de concorrentes, pois tais medidas permitem que os bens sejam produzidos a preços inferiores e, aceitando-se a teoria da Escola de Chicago sobre a divisão dos excedentes com os consumidores, sejam oferecidos no mercado a preços inferiores, se comparados aos ofertados sem as economias de escala.

As economias de escopo, outro fator a justificar a ação coordenada, pressupõem a redução dos custos de produção de dois ou mais produtos, caso sejam fabricados pelo mesmo agente econômico - ou seja, a produção conjunta é mais barata do que a produção separada. Essas economias estão relacionadas: à existência de reserva de capacidade (os insumos podem ser compartilhados para a produção de mais de um produto); à existência de fatores comuns (ou seja, à aquisição de fatores de produção que só se adquirem uma vez e que podem ser aproveitados para mais de um bem como, por exemplo, uma mesma lâmpada que serve para a confecção do produto A e B); e a complementaridade, que pode ser técnica, comercial, etc (como por exemplo, investimentos comuns em marketing para dois produtos diversos) ${ }^{79}$.

Mais uma vez é de se supor que apenas os grandes agentes econômicos, que oferecem no mercado uma ampla gama de produtos, poderiam ser beneficiados por esse tipo de economia. Caso os agentes pudessem produzir os seus bens conjuntamente, seria possível que essas vantagens também fossem usufruídas por agentes de menor porte. Pela importância das eficiências trazidas pelas economias de escala e de escopo, elas são objeto da lei concorrencial brasileira, que abre uma exceção para a realização de atos de

\footnotetext{
78 Enumeramos apenas as economias de escola estáticas, ou seja, não sujeitas ao fator tempo. Para as dinâmicas e outros aprofundamentos sobre o tema, consultar DAVID KUPFER e LIA HASENCLEVER, Economia industrial - Fundamentos teóricos e práticas no Brasil, São Paulo, Editora Campus, 2002. No mesmo sentido Glossário da Secretaria de Acompanhamento Econômico, disponível em www.seae.fazenda.gov.br/central_documentos/glossarios/E, acesso em 24 nov. 2008.

79 Mais uma vez, para estudos detalhados, consultar DAVID KUPFER e LIA HASENCLEVER, op. cit.
} 
concentração que possam prejudicar a livre concorrência na medida em que propiciem a "eficiência" e o "aumento da produtividade" (esse assunto será mais bem debatido no Capítulo 8).

Outro exemplo de vantagem na atuação conjunta de concorrentes está na união de empresas para a realização de empreendimentos que dificilmente poderiam ser suportados isoladamente. Esse é o caso das joint ventures, assim definidas por WALDIRIO BULGARELLI "trata-se de uma espécie de consórcio que se aproxima da fusão (quasi merger), mas que desta se diferencia por não apresentar estabilidade e permanência por, em geral, visar a objetivos específicos limitados, como os grandes projetos de obras de infra-estrutura, portos, túneis, hidroelétricas etc., cuja magnitude exige a união de várias empresas" $"$. Esse tipo de arranjo também é bastante utilizado para a pesquisa e desenvolvimento de novas tecnologias, como as medicamentosas e as da indústria de alta precisão, que exigem vultosos investimentos para o seu financiamento, nem sempre passíveis de serem suportados pelos particulares.

A utilidade da ação coordenada justifica, ainda, a existência das chamadas associações de classe, que prestam serviços de divulgação de informações e de defesa dos interesses dos membros de determinada categoria. Tais entidades, ao agregarem agentes de um mesmo segmento, são capazes de processar maior quantidade de informações se comparadas àquelas que seriam coletadas por cada um deles isoladamente. Além disso, possuem maior força na luta pelos interesses coletivos.

Diante dos argumentos ora expostos, é de se indagar o motivo pelo qual as autoridades concorrenciais exercem o rígido controle a que nos referimos. A resposta para a questão está na necessidade de supervisão de um tipo especial de acordo, denominado genericamente de $\operatorname{cartel}^{81}$. Esses acordos entre concorrentes são realizados para o

80 Concentração de empresas e Direito antitruste, 2. Ed., São Paulo, Atlas, 1996, p. 56-57.

81 "Cartels are generally considered among the most serious competition infringements. Competition authorities around the world are increasing their efforts to pursue cartel offences, both domestically and internationally. The harmful effects of hard core cartels are well understood. Consumers benefit from competition through lower prices and better products and services. When competitors agree to forego competition for collusion, consumers lose those benefits. The competitive process only works when competitors set prices independently. Secret cartel agreements are a direct assault on the principles of competition and are universally recognized as the most harmful of all types of anticompetitive conduct" (INTERNATIONAL COMPETITION NETWORK, op. cit). 
estabelecimento de variáveis como preços, quantidades ${ }^{82}$, divisão de mercado, políticas de venda, entre outras, sem que para tanto contem com a autorização do Estado. Conforme se observará abaixo, suas atividades são usualmente nocivas à concorrência e aos consumidores, sem qualquer justificativa econômica, retiram do mercado a saudável disputa entre os agentes, responsável pela diminuição dos preços no mercado e pelo impulso para o progresso tecnológico. Na definição de ROBERT H. BORK: "The subject of cartels lies at the center of antitrust policy. The law's oldest and properly qualified, most valuable rules states that it is illegal per se for competitors to agree to limit rivalry among themselves" $" 83$.

Nesse compasso, algumas legislações concorrenciais estabeleceram condenações per se para os cartéis, como explica SHYAN KHEMANI “[...] alguns países consideram os acordos de cartéis ilegais, independentemente de as restrições à produção ou à fixação de preços serem aceitáveis ou não. Sob tal perspectiva - chamada, nos Estados Unidos, de abordagem 'per se' -, o autor do processo ou vítima precisa apenas provar que o acordo foi feito e que poderia gerar efeitos contrários à concorrência. Não pode ser alegado como defesa que o acordo não fora realizado ou que não produziu efeitos anticompetitivos. Tampouco o querelante precisa provar que os acusados têm participação no mercado suficiente para elevar preços ou reduzir a produção" ${ }^{\text {"84 }}$.

A existência desse tipo de acordo, entretanto, não é tão simples quanto se procura apregoar. São necessárias algumas características básicas para que ele possa ser profícuo. A maior suscetibilidade para sua existência, como já afirmado pelos teóricos da Escola de Harvard, está naqueles mercados nos quais há um reduzido número de players e no qual existem altas barreiras à entrada. São os conhecidos mercados oligopolizados (a esse respeito, consultar a nota 85$)$.

Além disso, para que o cartel se mantenha firme e estável, é necessário que o produto não sofra concorrência de nenhum outro substituto e que os bens oferecidos pelas empresas participantes do acordo sejam homogêneos. Caso não sejam vistos como

82 Com a ressalva de que, de acordo com a microeconomia e com as leis da oferta e da procura, alterações nas variáveis preço e quantidade são determinantes uma da outra.

83 The antitrust paradox, New York, Basic Books, 1973, p. 263.

84

Op. cit., p. 63. 
plenamente substituíveis, haverá a possibilidade de que os compradores se disponham a pagar preços diferenciados, o que acaba com qualquer lógica em manter os preços fixos. $\mathrm{Na}$ hipótese de o preço fixado pelos agentes cartelizados estar muito acima daquele que seria praticado em condições normais de mercado, há grande tentação para a quebra do pacto, o que levará o player traidor ao aumento de suas vendas e de participação no mercado (tendo em vista que irá oferecer os produtos a preços inferiores aos praticados pelos demais).

Há ainda a questão dos custos. Para que a colusão possa ser bem sucedida, a estrutura de custos dos membros do acordo deve ser ao menos similar. Caso contrário, a definição dos preços e quantidades que irão maximizar o lucro do cartel será bastante problemática, incitando a sua quebra: uma empresa com custos marginal de produção inferior tenderá a aplicar preços menores e a produzir maior quantidade de bens, enquanto aquela não tão eficiente tenderá a produzir menos e a vendê-los por valor superior. Pensando-se com base no conceito de economias de escala, verificamos a existência de um outro fator a dificultar o ajuste entre empresas que possuam grande parcela de custos fixos: quanto mais produzirem e venderem os seus bens, mais eles serão diluídos, tornando a produção competitiva. Logo, é de interesse dessas empresas venderem o maior número de mercadorias possível, o que pode ser impedido pelo acordo entre os concorrentes.

Como se percebe, o estabelecimento do acordo não é o único fator problemático para a constituição de um cartel. A sua manutenção ao longo do tempo também é, visto todos os fatores que incitam a traição. Logo, há necessidade de constante vigilância para que nenhum dos membros caia em tentação, o que gera altíssimos custos de monitoramento. Assim, é preciso que se tenha em mente que os cartéis, que tanto tormento trazem para as autoridades antitruste, dependem, para sua existência, de uma série de condições, inclusive estruturais, para que sejam formados e possam se manter firmes ao longo do tempo.

\subsection{Justificativas para a sua existência}

Para entender o funcionamento dos cartéis e justificar a sua existência (a despeito da atuação das autoridades antitruste), vamos nos valer do modelo de mercados 
perfeitamente competitivos, segundo o qual encontramos no mercado dois tipos de cenários ${ }^{85}$.

No primeiro, dito de monopólio, há apenas uma empresa atuando, sem que qualquer outra lhe ofereça concorrência. Nessas condições, o agente pode colocar no mercado o produto com a tecnologia e características que melhor lhe aprouverem, sem que o consumidor possa buscar outro fornecedor. Mais importante: o empresário pode praticar o preço que entender mais conveniente, sem que o adquirente possa optar pela compra de produto substituto ${ }^{86}$.

Porque todos os produtos oferecidos no mercado provêm de uma única fonte - a sua própria - o agente pode controlar a quantidade de bens oferecidos, de forma a maximizar os seus resultados. Consegue esse objetivo ao colocar à disposição dos

85 Esse modelo descreve apenas os mercados perfeitamente competitivos e os monopolistas, deixando de avaliar a posição dos mercados nos quais existem poucos vendedores e no qual a concorrência não costuma ser tão agressiva como os de concorrência perfeita, chamados oligopólios. Também deixaremos de analisar os mercados monopolisticamente competitivos, nos quais os produtos não são homogêneos entre si. Para uma visão mais aprofundada do tema, necessária a consulta às obras de PIERO SRAFFA, especialmente de seu artigo "The laws of returns under competition conditions", no qual os pressupostos neoclássicos começaram a ser desafiados, com discussões sobre os mercados de competição imperfeita. Na mesma esteira, os artigos "The economics of imperfect competition", de JOAN ROBINSON e "The theory of monopolistic competition", de EDWARD CHAMBERLIN. Com a restrição metodológica, deixaremos de avaliar importantes questões relativas ao comportamento dos agentes, especialmente a teoria dos jogos que, de certa forma, poderia ser utilizada para explicar o comportamento colusivo. O estudo dessa teoria permite compreender com maior precisão a motivação dos agentes quando da tomada de decisões. O famoso dilema do prisioneiro ilustra sua aplicação em um cenário de empresas oligopolistas: "As empresas oligopolistas frequentemente se encontram em situação semelhante à do Dilema dos Prisioneiros. Elas precisam decidir se concorrerão agressivamente, procurando obter uma fatia maior do mercado à custa de sua concorrente, ou se optarão por 'cooperar', competindo mais passivamente e coexistindo com suas concorrentes, aceitando manter inalterada sua atual fatia do mercado, e talvez até implicitamente praticando conluio. Se as empresas competirem passivamente, determinando preços elevados e limitando seus respectivos níveis de produção, elas poderão auferir lucros mais elevados do que se competissem agressivamente. Entretanto, da mesma forma que os prisioneiros, cada empresa poderá sentir-se estimulada a 'furar' e vender por menos que a concorrência. Eis que, entretanto, cada uma delas sabe que seu concorrente tem incentivo semelhante. Por mais desejável que a cooperação possa ser, cada companhia está preocupada - e com bons motivos - com a possibilidade de que, ao praticar a competição passiva, sua concorrente passe a competir agressivamente, obtendo assim uma fatia maior do mercado". ROBERT PINDYCK e DANIEL RUBINFELD, op. cit., p. 492.

86 Mais uma vez, utilizaremos o modelo econômico simplificado, trazido pela Escola Neoclássica, ignorando a existência de bens substitutos para o consumidor, não havendo que se falar em produtos ou em estratégias diferenciadas por parte dos produtores. Assim, por esse modelo, devemos entender que os produtos são insubstituíveis, sendo produzidos ou não por diversos fornecedores. Tomando-se o clássico exemplo da doutrina, não podemos considerar que existiria substituição entre a margarina e a manteiga, apenas considerar que o produto margarina é oferecido pelos produtores $\mathrm{A}, \mathrm{B}$, ou C. Em uma visão tradicionalista, a concorrência ocorre unicamente com relação à variável preço, não existindo qualquer outra. O modelo, portanto, ignora as descobertas trazidas por J. SCHUMPETER, segundo as quais a concorrência no sistema capitalista ocorreria de forma dinâmica e evolutiva, e inovação (e, portanto, a sua diferenciação), seria um aspecto de grande importância para a dinâmica empresarial, responsável pelos lucros extraordinários. Para estudos mais detalhados, consultar ROBERT PINDYCK e DANIEL RUBINFELD, op. cit. 
consumidores quantidade inferior àquela que seria encontrada em um cenário no qual mais de uma empresa atuasse no mercado - a definição da quantidade oferecida é feita tendo como base o seu lucro marginal: produz-se até que a receita marginal se iguale ao custo marginal de produção do bem ${ }^{87}$.

No segundo, temos o mercado perfeitamente competitivo (ou de competição perfeita $)^{88}$, no qual a empresa vende seu produto juntamente com outros fornecedores. Aqui existe a opção para que o consumidor compre do fornecedor A ou de muitos outros. Diante desse quadro, cada um dos players possui estímulo para que seus produtos sejam melhores ou mais atraentes do que os de seus concorrentes. Na linguagem da ciência da administração de empresas, cada empresário busca que seus bens ofereçam o maior número de "fatores ganhadores de pedidos" 89 , garantindo que sejam escolhidos em detrimento dos outros.

87 Para elucidação desses conceitos, consultar ROBERT PINDYCK e DANIEL RUBINFELD, op. cit.

88 "Trata-se do modelo de concorrência perfeita. Pouco encontrados na realidade, constituem mais uma abstração teórica explicativa do funcionamento dos mercados e do comportamento de seus agentes em regime de concorrência pura, do que propriamente uma descrição da realidade. A utilização desse modelo serve, porém, de contraponto aos mercados concentrados - em situação de monopólio ou oligopólio - que impõem custos aos consumidores e à sociedade em geral, devendo, por essa razão, ter sua formação coibida ou sua conduta regulada. A existência de concorrência perfeita depende de algumas condições, cuja identificação presta-se também à avaliação das condições de concorrência em outros mercados nos quais não exista, porém, concorrência perfeita. A principal das condições que definem o mercado perfeitamente competitivo é a existência de um grande número de produtores e de compradores, todos eles pequenos com relação ao todo, e, assim, incapazes de afetar, a partir de suas decisões individuais, o preço do bem ou serviço e a conduta de outros concorrentes. Dessa forma, nenhuma empresa poderia individualmente elevar o preço do bem, pois isso resultaria na perda de suas vendas; ou abaixá-los substancialmente, já que sofreria prejuízos diante dos custos de produção. Por outro lado, nenhum deles poderia tentar reduzir unilateralmente sua oferta, já que essa parcela não vendida seria facilmente suprida pelos concorrentes. Nessa perspectiva, o preço no mercado perfeitamente competitivo seria considerado pelos produtores e compradores como um dado, não passível de modificação pela conduta individual de cada um deles. Na medida em que não podem influenciar os preços de modo a aumenta sua lucratividade, as empresas tentam maximizar seus lucros produzindo até que o seu custo marginal se iguale ao preço - o qual, repita-se, para elas é um dado. O preço, por sua vez, é determinado pela interação entre oferta e procura totais do mercado. Aumentando a oferta o preço cai e vice-versa. Note-se que no modelo de mercado perfeitamente competitivo não existe lucro, estando embutida nos custos uma remuneração ao produtor pelo seu trabalho de combinação dos fatores de produção e investimento. Outras condições necessárias para que um mercado possa ser definido como perfeitamente competitivo são: a homogeneidade dos produtos e serviços oferecidos no mercado; o acesso pleno de todos os agentes às informações relevantes àquele mercado; a mobilidade dos fatores de produção e dos agentes de mercado ou - pode-se dizer - a existência de barreiras à entrada e à saída dos agentes, podendo eles ingressar ou se retirar de diferentes atividades, conforme as sinalizações de mercado" (ANA MARIA NUSDEO, op. cit., p. 32-33).

89 "Fatores competitivos ganhadores de pedidos são aqueles que diretamente ganham negócios adicionais para a operação. Eles são a principal razão pela qual os consumidores escolhem comprar o produto ou serviço. Se a operação melhora seu desempenho em fatores competitivos ganhadores de pedidos, ela vai ganhar mais negócios ou aumentar as chances de ganhar mais negócios” (NIGEL SLACK, STUART CHAMBERS e ROBERT JOHNSTON, Administração da produção, São Paulo, Atlas, 1997). 
Além da melhoria da qualidade dos produtos, temos que o grande número de fornecedores impede que um deles, isoladamente, possa impactar significativamente os preços praticados no mercado (os preços seriam então definidos pela Lei da oferta e da procura, divulgada pela economia neoclássica e nenhum dos agentes deteria poder de mercado).

Nesse cenário, afirma-se que o preço praticado será estabelecido pelo próprio mercado e que, nessa medida, compradores e fornecedores serão meros tomadores de preços: caso o fornecedor coloque os seus acima daqueles usualmente praticados, os consumidores simplesmente optarão por comprar os bens de outros fornecedores disponíveis; se, por outro lado, optar por reduzir seus preços, não conseguirá colocar no mercado quantidade de produtos suficiente para justificar a perda financeira do desconto oferecido (ele precisaria de maior volume de vendas para conseguir o mesmo lucro que obteria antes da redução de preços) ${ }^{90}$. Nesse cenário de plena competição, é usual que o número de unidades colocadas à disposição dos consumidores seja determinado pelo momento no qual o custo marginal de produção do bem se iguale ao preço praticado no mercado. É esse ambiente irreal, de concorrência perfeita, que a Escola Neoclássica toma como padrão para suas análises.

A comparação ora efetuada confirma a célebre frase de IHERING, difundida por PAULA A. FORGIONI, segundo a qual a concorrência é o regulador natural do egoísmo: no primeiro quadro, o produto não será ameaçado por nenhum outro e, nesse sentido, não há estímulo para que os empresários invistam em melhorias ou barateiem seus preços (ou seja, não há estímulo para que detenham maior número de "fatores ganhadores de pedidos"). Já no segundo, o agente econômico procurará continuamente oferecer o bem mais atrativo, para que seja eleito pelo consumidor. Além disso, seus preços não serão unilateralmente estabelecidos.

Presume-se que no primeiro exemplo temos a descrição da situação de mercado ideal para qualquer agente econômico: nele é possível exercitar seu egoísmo, cobrando

90 "A principal diferença entre uma empresa competitiva e um monopolista é a capacidade que este tem de influenciar o preço de seu produto. Uma empresa competitiva é pequena em relação ao mercado em que opera e, portanto, toma o preço de seu produto como dado pelas condições de mercado. Em contraposição, um monopolista, como único produtor em seu mercado, pode alterar o preço de seu bem ajustando a quantidade que oferta no mercado". N. GREGORY MANKIW, Introdução à economia, 3. ed., São Paulo, Cengage Learning, 2008, p. 318. 
preços maximizadores de seus lucros, em detrimento do consumidor, cativo de único fornecedor ${ }^{91}$. Aqui se evidencia um ambiente de prejuízo para os consumidores: há uma evidente perda social pelo fato de reduzir-se o número de pessoas que terão acesso aos bens produzidos (preços mais altos certamente desencorajarão ou impedirão que muitos consumidores adquiram o bem). Na segunda situação, pelos motivos já apontados, os agentes não poderão impor tais condições, sob pena de o consumidor simplesmente optar por adquirir os produtos do concorrente. Aqui é claro o benefício trazido pela concorrência, seja na forma de preços menores, seja na forma de maior desenvolvimento tecnológico dos bens ofertados ${ }^{92}$.

E são justamente as diferenças gritantes entre essas duas situações que justificam a existência dos cartéis ${ }^{93}$ : ao atuarem conjuntamente, os competidores procuram alterar as condições normais do mercado, transformando a dura realidade do mercado perfeitamente competitivo na doce situação trazida pela atuação isolada no mercado. Ou, nas palavras de N. GREGORY MANKIW: "Uma vez formado um cartel, o mercado passa, na prática, a ser atendido por um monopólio [...]"94-95-96.

$91 \quad$ Não discutiremos o problema da teoria do agente, segundo a qual, especialmente nas grandes empresas, poder-se-ia duvidar de que os administradores realmente tomam suas decisões baseados na busca da maximização dos lucros. Consideremos um modelo comum, no qual as empresas efetivamente buscam a solução maximizadora de seus lucros. A simplificação do modelo é explicada por ROBERT PINDYCK e DANIEL RUBINFELD: “A suposição de maximização de lucros é freqüentemente utilizada pela microeconomia pelo fato de prever o comportamento empresarial de forma razoavelmente acurada, evitando complicações analíticas desnecessárias. Porém, saber se as empresas buscam ou não a maximização de seus lucros tem sido um tema controverso. No caso das empresas menores, administradas por seus proprietários, o interesse pelo lucro provavelmente dominará todas as decisões da empresa. Nas empresas maiores, entretanto, os administradores que tomam as decisões do dia-a-dia geralmente têm pouco contato com os proprietários (isso é, os acionistas). Conseqüentemente, os proprietários das empresas não podem monitorar o comportamento dos administradores com regularidade. Estes dispõem, portanto, de alguma liberdade de atuação em termos de gestão de empresa, podendo de alguma forma desviar-se do comportamento capaz de maximizar os lucros. Os administradores poderiam estar mais preocupados com metas de maximização de receita, visando ao crescimento ou pagamento de dividendo para satisfazer os acionistas, do que com a maximização de lucros" (Op. cit., p. 267).

92 "Os acordos horizontais têm como pressuposto um fato inegável: a concorrência, ainda que lícita, prejudica os concorrentes, pois faz com que o empresário acabe por aferir lucros menores, força o cuidado com a qualidade do produto e gera a necessidade de investimentos para que o agente econômico possa manter-se no mercado competindo" (PAULA A. FORGIONI, Os fundamentos do Antitruste, cit., p. 396).

93 "In the absence of legal impediments competitors would like to join together in the hope of eliminating competition among themselves, thereby restricting output and rising prices" (AREEDA e KAPLOW, Antitrust analysis, problems, text, cases, 4. ed., Boston, Little, Brown \& Co., 1988, p. 188).

$94 \quad$ Op. cit., p. 348.

95 O exemplo apenas ilustra de maneira simplificada os benefícios que a ausência de competição traz ao agente. Para a aproximação, não levamos em consideração os estudos econômicos que bem diferenciam a 


\subsection{A problemática ao longo dos séculos}

Os cartéis têm sido alvo da disciplina governamental desde a antiguidade ${ }^{97}$. A justificativa para esse cuidado está primordialmente ligada a dois fatores: o poder por eles exercido ao longo do tempo e a possibilidade de suas atividades causarem sérios danos aos mercados e à sociedade.

\subsubsection{O poder}

Apesar de termos relatos da presença de cartéis desde a Antiguidade, só na Idade Média é que encontraremos descrições contundentes sobre sua atuação. Com efeito, as corporações de ofício $^{98}$, expoentes desse período histórico, nada mais eram do que agrupamentos de profissionais que, cartelizados, controlavam os mais variados aspectos da produção.

É dentro dessa ótica que devemos entender a obrigatoriedade de que cada artesão fosse filiado a determinada associação de classe, o que permitia a rígida fiscalização sobre o número de profissionais que atuavam no mercado. Para exemplificar, podemos imaginar que todos os sapateiros da cidade de Nantes deveriam ser aceitos em determinada corporação de ofício, única autorizada a produzir calçados naquela localidade. Em uma

estrutura dos oligopólios das dos monopólios, especialmente em relação aos custos para a manutenção do conluio. Outra importante simplificação refere-se a assunção de que os preços praticados pelos membros do cartel seriam iguais aos preços praticados em condição de monopólio. Segundo os estudos microeconômicos, nessas situações, os preços podem ser alterados por questões como as relativas às barreiras de entrada (necessidade de fixar preços inferiores aos de monopólio para que seja desestimulada a entrada de novos concorrentes no mercado) e pela fixação do preço comum a ser praticado pelo conluio em patamares que possam atender à estrutura de custos de todas as empresas).

96 "Quando bem-sucedidos, os cartéis produzem efeitos similares aos da monopolização de mercados, com a redução da produção e aumento do preço do produto. No entanto, são bem mais voláteis do que o monopólio, pois nem sempre os interesses do cartel como um todo coincidem com o de cada um dos participantes. Esses últimos, embora beneficiando-se da redução da concorrência possibilitada pelo acordo, levariam vantagens ainda maiores se conquistassem parcela maior do mercado, através de descontos ou outras formas de redução de seu preço" (ANA MARIA NUSDEO, op.cit., p. 36).

97 Usaremos a palavra "governos" como qualquer forma de poder estabelecido, como a exercida pelos reis, senhores feudais, entre outros.

98 Tomaremos a expressão "corporação de ofício" como sinônima de corpos de ofício, tendo em vista a advertência de Braudel de que a primeira somente foi cunhada em 1791, com a Lei Le Chapelier. 
clara barreira à entrada no mercado, os sapateiros não poderiam oferecer seus produtos no mercado caso não pertencessem à associação, o que significava, de fato, a expulsão e a ruína econômica dos trabalhadores que não conseguiam a filiação ${ }^{99}$.

Além de serem aceitos nos quadros da corporação, os artesãos deviam obedecer aos seus rígidos estatutos, que regulavam de forma minuciosa todos os aspectos da produção e colocação dos produtos no mercado. Preços, quantidades, qualidade e padrões eram determinados para que as concorrências entre os membros da corporação se mantivessem dentro dos níveis previamente estabelecidos.

Resume TULLIO ASCARELLI: "A miúda disciplina interna das corporações artesanais é orientada, freqüentemente, com intento monopolístico, no sentido de evitar a concorrência, pelos termos da superprodução (de onde a proibição aos não matriculados de exercício da atividade regulamentada [...]). Mas, independente disso, desenvolve-se também uma ordenação normativa que tem por objeto a disciplina dos negócios mercantis, isto é, em substância, negócios de intermediação nas trocas" ${ }^{\prime 100}$.

A similaridade entre a estrutura das corporações de ofício e a dos cartéis é muito grande. Veja-se:

i) a obrigatoriedade de filiação às corporações cumpria duas finalidades: controlar o número de profissionais atuantes no mercado e garantir que suas regras fossem seguidas por todos os que nele atuassem;

ii) o controle da quantidade produzida pelos associados viabilizava a determinação dos preços pela própria corporação e não pelas leis da oferta e da procura;

iii) a padronização em aspectos como qualidade, cor, entre outros, tornavam os produtos indiferentes.

99 FERNAND BRAUDEL afirma: “em Veneza, aquele cujo nome não figurasse nos registros de uma confraria [Scuola] era considerado o último dos homens" (Civilização material, economia e capitalismo séculos XV-XVIII - os jogos das trocas, São Paulo, Martins Fontes, 1998, p. 441).

100 TULLIO ASCARELLI, Corso di diritto commerciale: introduzione e teoria dell'impresa, Milano, Giuffrè, 1962, p. 87-100, tradução livre do autor. 
Todas essas medidas buscavam construir uma estrutura na qual aos consumidores fosse indiferente comprar do produtor A ou B ou mesmo moldar o ambiente para que a eles só fosse dada a oportunidade de adquirir de um único fornecedor. Ou seja, A e B deveriam ser vistos como se fossem um único agente econômico. Atuando dessa maneira, as corporações de ofício podiam cobrar preços de monopólio por seus produtos, a despeito de, na realidade, existirem vários produtores. Esses efeitos - de arrefecimento da concorrência - são os mesmos buscados pelos agentes econômicos quando se associam para a formação de um cartel ${ }^{101}$.

Como a história nos relata, com o passar do tempo as corporações de ofício tornaram-se detentoras de poder que, não raras vezes, ofuscava o exercido pelas autoridades locais. As justificativas para tamanha influência são facilmente percebidas:

i) elas podiam decidir, unilateralmente, quem seria agraciado com a possibilidade de trabalhar e oferecer seus produtos no mercado e quem, desafortunadamente, deveria dele ficar afastado.

ii) os preços praticados no mercado, ditados unilateralmente pelas associações, deveriam ser pagos independentemente de qualquer discussão pelos consumidores, que eram cativos da estrutura montada pelo cartel; e

iii) essas associações acumularam ao longo do tempo grandes fortunas e prestígio social, tornando o seu apoio político de extrema importância para as autoridades locais e para os nascentes Estados Nacionais.

\footnotetext{
101 Nesse mesmo sentido, afirma MANOEL JORGE E SILVA NETO: "As corporações de ofício medievais guardam impressionante similitude com os cartéis que grassam nos sistemas econômicos atuais, principalmente em face da existência de um dado que muito os aproxima: a comunhão de interesses. De modo iniludível, os interesses determinantes da organização e da preservação da atividade dos artesãos na Idade Média representam o mesmo móvel à iniciativa dos segmentos econômicos atuais no sentido de abolir a margem diferencial de preços por meio da cartelização. No específico caso das Corporações de Ofício, as normas estatutárias disciplinadoras da atividade habitualmente ofendiam a liberdade concorrencial por força da submissão às exigências relativas ao atendimento dos requisitos para ingresso na entidade (caracterizando fortíssimas barreiras ao ingresso); diante da determinação do local onde se desenvolveria o exercício da atividade do artesão (impedindo-se, desta forma, que dois ou mais integrantes da Corporação pudessem disputar a mesma clientela) e, sobretudo, mediante a imposição de preços mínimo e máximo a serem cobrados pela execução do serviço ou pela venda do produto. Com isso, obtida a uniformidade dos preços, restaria inapelavelmente comprometida a concorrência" (Op. cit., p. 179).
} 
As iniciativas para minimizar o poder e influência exercidos pelos acordos entre concorrentes remontam a essa época da História ${ }^{102}$.

\subsubsection{Os danos}

O segundo motivo encontrado para a rígida disciplina dos cartéis está na possibilidade de suas atividades causarem danos aos mercados e aos consumidores, comprometendo, por vezes, a própria estabilidade social.

No modelo de concorrência acima descrito, verificamos como o acordo entre os players pode alterar as condições naturais do mercado, retirando os benefícios trazidos pela competição e causando prejuízo aos demais agentes econômicos. Retomando o quanto já observado, os malefícios podem ser assim sistematizados:

i) possibilidade de preços mais altos serem cobrados dos consumidores, em detrimento dos determinados pelas leis de mercado; e ii) desincentivo à inovação e investimento em melhoria de produtos.

Os danos podem se tornar ainda mais intensos caso o acordo entre concorrentes recaia sobre bem de grande importância para a população, como é o caso do sal marinho. Se hoje o temos presente em praticamente todas as casas como tempero alimentar, na antiguidade, o produto desempenhava função primordial, sendo utilizado, em uma época na qual não havia a indústria farmacêutica e os refrigeradores, como terapêutico e conservante de alimentos ${ }^{103}$.

Um acordo para a determinação dos preços do sal não poderia ser considerado um mero acordo entre concorrentes: se um ajuste para o controle da produção de sapatos

\footnotetext{
102 A respeito desse tema, consultar de minha co-autoria, As associações e o novo Código Civil, publicado na coletânea coordenado por ERASMO VALLADÃO AZEVEDO E NOVAES FRANÇA As Associações e o Novo Código Civil, São Paulo, Quartier Latin, 2009.

103 "Os egípcios foram provavelmente os primeiros a curar carne e peixe com sal. O mais antigo registro chinês da preservação de peixe em sal data aproximadamente de 2000 a.C. No Egito, peixes e aves salgados foram encontrados em túmulos de períodos bem anteriores. $\mathrm{O}$ processo de curar com sal observa a umidade na qual se desenvolvem as bactérias. Além disso, o próprio sal mata as bactérias. Entre as impurezas encontradas no antigo cloreto de sódio havia outros sais, como o salitre, que são bactericidas ainda mais agressivos. Quando expostas ao calor, as proteínas se desnaturam, assim como quando são expostas ao sal. Portanto, a salga tem efeito semelhante ao do cozimento". MARK KURLANSKY, Sal - uma história do mundo, São Paulo, Senac, 2004, p. 53.
} 
poderia trazer problemas para a população - como o ter de utilizar por maior período de tempo um calçado velho, o acordo para o controle do preço do sal estava relacionado à própria sobrevivência do homem, dado que este não poderia simplesmente optar por não comprá-lo por determinado período de tempo ${ }^{104}$. A não interferência dos governos sobre os preços praticados em relação a produto de tamanha importância poderia levar, até mesmo, à perturbação da paz e à instabilidade social.

A essencialidade e os abusos cometidos pelos conluios trouxeram novos fatores a justificar o controle dos cartéis ${ }^{105}$. Nesse sentido, assistimos à edição de inúmeros textos legislativos que reconheciam as mazelas originadas por sua atuação e procuravam coibirlhe a atividade, como o já citado Sherman Antitrust Act de 1890. Desde então, e até os dias atuais, observamos o surgimento de diplomas disciplinando os acordos entre concorrentes $^{106-107}$.

Hodiernamente, a repressão aos cartéis conta não apenas com a imposição de pesadas multas para as empresas partes do acordo, como também com sanções penais (como a de emprisionamento) para as pessoas físicas participantes. $\mathrm{O}$ endurecimento na legislação reflete o entendimento de que apenas a aplicação da cominação financeira não era suficiente para impedir os acordos, visto que, não raras vezes, os benefícios

$104 \quad$ "A dinastia Quin caracterizou-se pela tendência legalista a construir obras públicas imensas e estabelecer leis rigorosas. O monopólio que fixava o custo do sal e do ferro mantinha as duas mercadorias com preços excessivamente altos. É o primeiro caso conhecido na história de monopólio estatal de uma mercadoria essencial [...]. O governo romano, ao contrário do chinês, não detinha o monopólio sobre a venda do sal, mas não hesitava em controlar os preços do produto quando parecia necessário. $\mathrm{O}$ mais antigo registro da intervenção governamental nos preços do sal data de 506 a.C., somente três anos antes de o reino ser declarado uma república. O Estado assumiu o comando da principal fonte de sal em Roma - uma salina de propriedade particular em Óstia -, porque o rei achou que os preços estavam excessivamente altos. Tanto sob a república como, mais tarde, sob o império, o governo romano periodicamente subsidiava o preço do sal para garantir que os plebeus não tivessem dificuldade em comprá-lo. Era um presente, semelhante a uma redução de impostos, que o governo concedia quando necessitava de apoio popular. Às vésperas da decisiva campanha naval em que derrotou Marco Antônio e Cleópatra, o imperador Augusto conquistou apoio público distribuindo azeitonas e sal gratuitamente" (MARK KURLANSKY, op. cit., p. 46 e 76).

105 Veja-se que, muitas vezes, o próprio Estado pode se tornar refém da atuação dos cartéis. Por exemplo: o Estado inglês com relação ao sal utilizado para a alimentação da Marinha Britânica e, nos dias atuais, a necessidade de os países comprarem seu petróleo da Organização dos Países Exportadores de Petróleo (OPEP).

106 Explica PAULA A. FORGIONI, tais acordos "tendem, muitas vezes, a viabilizar a reprodução de condições monopolísticas e, por essa razão, são tradicionalmente regulamentados pelas legislações antitruste”. Os fundamentos do antitruste, cit., p. 393-394.

107 No caso brasileiro, a condenação aos cartéis é prevista nos artigos 20 e 21 da Lei 8884/94. O combate aos cartéis foi estimulado ainda pela criação, pelo Decreto de 7 de outubro de 2008, do Dia Nacional de Combate aos Cartéis pelo governo federal. 
econômicos advindos de sua utilização em muito superavam os riscos do pagamento de sanções pecuniárias ${ }^{108}$.

\subsection{Necessária distinção entre os acordos entre concorrentes}

Observou-se que os prejuízos causados pela ação dos cartéis levaram à elaboração de disciplinas para limitar a sua atuação. Ocorre que tais legislações, destinadas ao combate dos cartéis tradicionais, acabaram sendo empregadas não apenas para o combate a essas estruturas, mas também a outros tipos de acordos entre concorrentes.

A utilização genérica certamente não é adequada, porquanto já se observou nesse trabalho que a ação coordenada entre concorrentes pode trazer benefícios ao mercado e aos consumidores. Ou seja, podem atender a objetivos pro-competitivos. Nessa linha, a ponderação de SHYAN KHEMANI: "E se um acordo não for uma restrição óbvia ao comércio? E se o acordo envolver uma integração de algumas ou todas as pesquisas, fabricação, operações de distribuição de uma empresa, ou implicar na criação de um produto ou método de distribuição novo e melhorado? Se a cooperação entre empresas aumentar a eficiência, essa conduta pode não ser condenada imediatamente, da mesma forma que os cartéis que não oferecem eficiências potenciais. Uma vez que se demonstrou que uma restrição potencialmente reforça a eficiência, o investigador deve determinar se a restrição é necessária para alcançar os objetivos pró-competitivos afirmados e se o acordo também puder criar ou facilitar o exercício do poder de mercado. Se o acordo tem eficácia potencial pró-competitiva juntamente com eficácia potencial anticoncorrencial, a autoridade de defesa da concorrência enfrenta o difícil problema de procurar equilibrar riscos de prejudicar o potencial de benefícios" ${ }^{109}$.

108 “[...] enquanto nos Estados Unidos o foco é colocar os empresários na cadeia, na Europa, a prioridade é impor multas de centenas de milhões de euros aos cartéis. São dois focos distintos de atuação, mas complementares" (JULIANO BASILE, Autoridades dos EUA e da Europa ajudam Brasil a combater cartéis, Valor Econômico, 13 out. 2009, disponível em: http://www.valoronline.com.br/?impresso/brasil/89/5865163/autoridades-dos-eua-e-da-europa-ajudam-brasila-combater-carteis, acesso no dia 11 jan. 2010).

109 E continua: "Felizmente, o efeito competitivo resultante na maioria das restrições horizontais tornarse-á claro antes que a agência concorrencial tenha que desempenhar essa tarefa. Muitas restrições não terão grande poder de lesar a concorrência, particularmente aquelas nas quais as partes juntas têm uma pequena participação no mercado ou aquelas cujas restrições em ações no mercado independente são bastante limitadas. Outras restrições não irão criar benefícios pró-competitivos, ou esses benefícios poderiam ser obtidos com restrições muito menores" (SHYAN KHEMANI (org.), op. cit., p. 81). 
Aqui podemos visualizar dois tipos de problema: o primeiro, o de se regular com a mesma firmeza acordos altamente prejudiciais e os de menos impacto - indo de um extremo a outro, teríamos sob a mesma denominação os acordos de grande magnitude, com potencialidade de lesar um grande número de consumidores (exemplo: acordo para fixação dos preços de parafusos entre todos os fabricantes do mundo), assim como os pequenos ajustes para divisão dos custos de exportação de determinado produto.

Para fins deste trabalho, há ainda um segundo problema, relacionado ao próprio emprego do termo "cartel". Explica-se: a despeito de a palavra se referir aos cartéis tradicionais, outras formas de coordenação também utilizam a expressão "cartel” em sua nomenclatura, como os cartéis de crise ${ }^{110}$ e os cartéis de exportação. $\mathrm{O}$ emprego indistinto

110 Com efeito, os cartéis de crise são permissões estatais para que agentes atuem conjuntamente em situações especiais, como as crises conjunturais. O elemento diferenciador, portanto, é a autorização governamental e a situação de crise (CALIXTO SALOMÃO FILHO, Direito concorrencial - as condutas, cit., p. 286). Um exemplo de cartel de crise pode ser encontrado no Japão, que em 1983 concedeu isenção para que um conjunto de pequenas e médias empresas atuasse concertadamente para lidar com a introdução de um novo imposto que estava aumentando seus custos (AKINORI UESUGI, How Japan is tackling enforcement activities against cartels, 13 George Mason Law Review, n. 349, 2004-2006, p. 356). ANA MARIA NUSDEO nos traz descrição detalhada da utilização desses instrumentos no Japão: “A regra da permissão à formação de cartéis parte da idéia de que em algumas situações o excesso de concorrência é prejudicial à atividade econômica e, portanto, ao interesse público. É o caso das crises que levam à redução da procura e, assim, à depressão de um setor. Os cartéis de depressão permitem aos agentes adaptarem-se a nova demanda do mercado, dividindo entre si o ônus e afastando seu temor da perda da fatia do mercado de cada um isoladamente. Por outro lado, alguns cartéis podem servir de instrumento para a consecução de metas econômicas específicas, que não seriam atingidas num regime de livre concorrência, como o desenvolvimento da tecnologia ou o aumento da eficiência de determinado setor objeto dos cartéis de racionalização. Assim, conforme a lei japonesa, os cartéis de depressão podem ser autorizados pela Fair Trade Commission se objetivarem restrições à produção ou às vendas ou, ainda, ao uso de instalações ou equipamentos. Apenas quando não for possível obter os resultados esperados desses acordos podem os cartéis de preço ser autorizados. Os cartéis de racionalização, por sua vez, podem ser aceitos para permitir atividades concertadas entre concorrentes com relação a restrições no uso de tecnologia ou na produção de alguns tipos de produtos, uso de instalações para depósito de matérias-primas ou produtos, transporte, ou utilização ou compra de subprodutos, restos ou sucata. Finalmente, o ministro da economia pode autorizar realização de cartéis em casos necessários por razões econômicas, no interesse público. Além dessas possibilidades de formação de cartéis estabelecidas na lei antimonopólio, foi bastante comum a criação de leis especiais nas quais se estabeleciam condições mais flexíveis para os cartéis. [...] Note-se que cartéis de exportação podem ser autorizados pelo Ministry of International Trade and Industry, com base em regras estabelecidas no Export-Import Trading Act, de 1952" (Op. cit., p. 116-117). Ainda sobre o tema, diz PAULA A. FORGIONI: "Aponta-se que, em períodos de crise, o volume de vendas pode declinar, obrigando alguns agentes econômicos a saírem do mercado. Passada a recessão, a volta dessas empresas implicaria custos adicionais de restabelecimento que poderiam, em alguns casos, inviabilizar o retorno. A concentração do mercado e a perda da capacidade do sistema, então poderiam ser evitadas se fosse permitida a neutralização da concorrência entre os agentes econômicos" (Os fundamentos do Antitruste, cit., p. 405). DANIEL GOLDBERG relata a experiência na União Européia: “[...] em 1978, a Comissão Européia ajudou a indústria européia a organizar o famoso cartel de fibras sintéticas. A indústria de fibras sintéticas européias situava-se, no final da década de 1970, em um vale de sobreoferta e preços declinantes. O então Comissário de Política industrial, Viscount Etienne Davignon, estimulou as maiores firmas da indústria a entrarem em acordo para reduzir oferta e capacidade de forma gradual. Evidentemente, a decisão causou algum tumulto junto ao membro da Comissão responsável pela política de concorrência. A pressão para que o acordo fosse considerado isento nos termos do art. 81 (3), contudo, só aumentava. Em um primeiro momento, o Diretor Geral responsável por concorrência (antigo $D G I V$, atual $D G$ Comp) afastou a possibilidade de outorgar uma 
do termo acaba por transferir para as outras estruturas os preconceitos associados aos cartéis tradicionais, o que prejudica a utilização dessas outras modalidades de ajuste entre concorrentes. Assim, seria de se indagar sobre a viabilidade de um acordo entre empresas em época de profunda crise econômica, formado para a proteção das empresas nacionais, ser disciplinado da mesma forma que um acordo mundial para a alta dos preços do cimento $^{111}$ ?

Da mesma maneira que entendemos necessário distinguir os cartéis dos demais ajustes entre concorrentes, é necessário distinguir os cartéis tradicionais de outros tipos de acordos (leia-se outros tipos de cartéis), para que possamos ter uma disciplina adequada a cada uma das situações. A esse respeito, notemos que, na língua inglesa, outras palavras, não relacionadas a cartel, são empregadas para designar as associações para exportação, tais como export association ou joint export trade organization.

Apoiando a necessidade de ser realizada essa diferenciação, o pronunciamento americano junto à Organização Mundial do Comércio - OMC: "It could be important to clarify the benefits of a competition or consumer welfare based approach as opposed to a market access driven approach to cartels and other practices. Concerning the references that had been made to export cartels, as many of the speakers had point out, a key consideration would be to exclude from a definition of hard core cartels types or arrangements that have a significant potential to enhance efficiency. Export cartels, despite their pejorative names, included a variety of possible arrangements, the competitive effects of which were uncertain. For example, the origin of what were termed the 'export cartels

isenção antitruste ao acordo, uma vez que o ajuste envolveria virtualmente todas as firmas européias com participação substantiva de mercado. Afinal, nos termos do art. 81 (3) do Tratado, uma isenção antitruste só poderia ser outorgada sob quatro condições - similares àquelas impostas no Brasil pelo art. 54 da Lei 8.884/94. O acordo precisa contribuir para a promoção de progresso técnico ou trazer eficiências produtivas, os consumidores precisam obter parte equânime dos benefícios, as restrições impostas pelo acordo competitivo precisam ser indispensáveis à obtenção dos alegados benefícios e, por fim, a competição nos mercados envolvidos não pode ser substancialmente eliminada. Parecia à Diretoria-Geral vinculada ao Comissário de Concorrência que o acordo entre os produtores de fibras sintéticas violava frontalmente os requisitos para a obtenção da isenção. Em 1984, contudo, a Comissão aprovou um acordo (variação daquele fomentado por Davignon) entre dez dos maiores produtores de fibras sintéticas que tenha por objeto o fechamento de $18 \%$ de sua capacidade produtiva" (Op. cit., p. 118-119).

111 DANIEL SOKOL, ao comentar o artigo de FLORIAN BECKER afirma: "One hypothesis, and certainly the hypothesis of Becker, is that export cartels are hard core cartels and create negative spillovers in other countries. In essence, export cartels allow countries to export their anticompetitive practices abroad while reaping the benefits of increased exports at home. This leads to a negative spillover problem. This problem is the rationale for creating an international trade regime in the first place." (What do we really know about export cartels and what the appropriate solution, In University of Florida Levin College of Law Research Paper n. 2009-05, p. 5). 
wars' in the United States, was simple to facilitate the ability of firms that might not otherwise have had the ability to engage in export to do so. In these cases, such arrangements clearly had pro-competitive effects ${ }^{112}$.

112 WTO, Report on the Meeting of 1-2 July 2002. WT/WGTCP/M/18, 20 Sept. 2002. No mesmo sentido: WTO, Communication from the United States. WT/WGTCP/W/203, 15 Aug. 2002. Ainda nesse sentido: "Export cartels may have efficiency justifications in which coordinated conduct is merely ancillary conduct to attain the aims of a coordinated venture. A joint venture among exporters may allow for economies of scale for small and medium sized exporter and may reduce the costs of doing business internationally. This may include administrative costs, advertising, and foreign sales agencies. Another effect to export cartels is that membership in such cartels may reduce the risk that any one company undertakes in foreign venture". DANIEL SOKOL. What do we really know about export cartels and what the appropriate solution, University of Florida legal studies research paper $n^{\circ} 2009-05$, p. 6. É importante se notar que a própria definição de hard core cartels trazida na Recommendation on Hard Core Cartels da OCDC de 1998 exclui os cartéis de exportação da sua definição, na medida em que "The definition of such cartels specifically excluded any arrangements that reasonably related to cost-reducing or output-enhancing efficiencies, those that were excluded from the coverage of a member country's own laws, or authorized in accordance with those laws" (ADITYA BHATTACHARJEA, Trade and Competition Policy, Indian council for research on international economic relations, cit., p. 20). 


\section{OS CARTÉIS DE EXPORTAÇÃO}

Observamos no Capítulo precedente que os cartéis de exportação devem necessariamente ser estudados de forma apartada dos cartéis clássicos. Agora é chegada a hora de reunirmos os elementos que justificam a diferenciação.

O primeiro deles é o seu objetivo. A idéia básica com a qual trabalharemos é a de que as associações para exportação são instrumentos, admitidos pelos governos, que permitem que empresas unam esforços para conquistarem melhores condições de competição no mercado internacional ${ }^{113}$. Trata-se, portanto, de uma visão "positiva", que associa os cartéis de exportação à políticas comerciais e de estímulo às exportações. Por outro lado, não é raro encontrarmos visões bastante diversas sobre os objetivos por eles perseguidos. A definição apresentada pela Organização para a Cooperação e Desenvolvimento Econômico - OCDE marca bem essa diferença: ela os retrata como acordos ou arranjos entre firmas para aplicar preço específico de exportação e/ou dividir os mercados de exportação ${ }^{114}$.

\footnotetext{
113 Os cartéis de exportação, a exemplo dos cartéis clássicos, também encontram dificuldades para sua formação (analisadas no Capítulo precedente). A esse respeito, nos informa ALEXIS JACQUEMIN que o sucesso dos cartéis de exportação depende da possibilidade de serem resolvidos problemas ligados à sua organização e sobrevivência. Assim, enumera os três principais pontos vulneráveis desse tipo de estrutura: a iniciativa para se organizar o cartel, a dificuldade de delimitar seu conteúdo e a sua abrangência geográfica (ALEXIS JACQUEMIN, TSURUHIKI NAMBU, ISABELLE DEWEZ, A dynamic analysis of export cartels: the Japanese case, In The Economic Journal, v. 91, n. 363, Sept. 1981, p. 686).
}

114 Definição disponível em: www.oecd.org/dataoecd/8/61/2376087.pdf, acesso em: 4 nov. 2008. No original: "An agreement or arrangement between firms to charge a specified export price and/or to divide export markets". Como exemplos de outras definições encontramos a de A. PAUL VICTOR, segundo a qual os cartéis de exportação são acordos que "[...] authorize firms to collaborate, to engage in anticompetitive behavior in foreign markets, at the expense of other countries" (Export cartels: an idea whose time has passed, In 60 Antitrust Law Journal 571, 1991, p. 571), ou a de MARGARET C. LEVENSTEIN e VALERIE Y. SUSLOW, definindo-os como "[...] simply a group of firms that nations permit to work together (sometimes with clear restrictions specifying over which dimensions they may or may not coordinate". (The changing international status of export cartel exemptions, In 20 Am. U. Int'l L. Rev., 20042005, p. 788). A FIESP os define como "Acordo entre empresas para praticar determinado preço de exportação ou dividir os mercados de exportação. Muitas legislações antitruste permitem este tipo de prática desde que não afete o mercado doméstico. A racionalidade em se permitir tal conduta advém do fato de que, do ponto de vista dos interesses estritamente nacionais, a exportação é benéfica na medida em que potencializa a penetração em mercados externos, favorece a balança comercial do país exportador e aloca renda dos consumidores estrangeiros para os produtores domésticos", disponível em: http://apps.fiesp.com.br/sbsnetv2/big/sindical-juridica/pdf/lexico_atual4.pdf, acesso em: 20 nov. 2008. 
Apesar de correta - na medida em que os cartéis de exportação podem realmente adotar procedimentos de unificação de preços e de divisão do território - o enfoque pode ser considerado um tanto enviesado, porquanto só realça o aspecto no qual os cartéis de exportação se aproximam dos cartéis clássicos. Quanto a esse ponto específico, temos a dizer que o estabelecimento de preços comuns e a divisão de território são características marcantes dos cartéis clássicos, porquanto permitem a maximização de seus lucros. Aqui há a apropriação indevida de riqueza da sociedade, em uma atitude que beneficia apenas aos membros do conluio. Por outro lado, os cartéis de exportação podem (mas nem sempre) ter como objetivo o aumento dos preços praticados ao consumidor. Certamente que o acordo resultará em vantagens para as empresas que participam do ajuste, na medida em que terão possibilidade de realizar negócios em mercados antes não atingidos, mas seus efeitos não se restringem a esses benefícios privados.

As vantagens, conforme já adiantadas no Capítulo 1, também estão relacionadas ao fomento da atividade interna, à maior disponibilidade de empregos, ao ingresso de divisas, entre outras. Ou seja, há contrapartidas para a sociedade, que podem o justificar. Nesse ponto fica nítido que os cartéis de exportação não podem ser disciplinados por uma visão estritamente focada na busca pela concorrência e eficiência, porquanto sua atividade tem reflexos em variados setores da economia, devendo ser "cuidados" por políticas públicas mais amplas. Uma discussão mais aprofundada sobre esse assunto será travada ao longo do Capítulo 8.

Nas palavras de SPENCER WEBER WALLER: "Purely private cartels are primarily motivated by desire to maximize profits. To accomplish this goal, private cartels coordinate prices and output, deter cheating by cartel members, and attempt to avoid detection from antitrust enforcement. When a foreign government is involved in the creation or implementation of a single-country export cartel, however, profit maximization may be only one of many goals being pursued by the cartel" $" 115$.

\footnotetext{
$115 \quad$ E continua: "Such cartel may simply be a twentieth century extension of mercantilist trade policies designed to exploit foreign markets for the benefit of national producers. On the other hand, a single-country export cartel may be used by home government to effectuate domestic economic policies, promote employment in export sectors, obtain hard currency from abroad, or implement international agreements and understandings rating from the prevention of dumping and countervailing duties to the resolution of international trade disputes through voluntary export restraints implemented through an export cartel" (The ambivalence of United States antitrust policy towards single-country export cartels, 10 Nw. J. Int'1 L. \& Bus. 98, 1989-1990, p. 99-100).
} 
O segundo ponto que justifica a diferenciação é o resultado que trazem para os consumidores. Os cartéis clássicos visam apenas à maximização de seu lucro e o fazem em detrimento do consumidor, que se prejudica pelo aumento dos preços e pelo desestímulo à concorrência. Os cartéis de exportação, por outro lado, podem resultar em benefícios para o consumidor. Consideremos as seguintes situações: os cartéis de exportação do tipo puro não afetam de qualquer forma o consumidor nacional, apenas trazem a eles benefícios indiretos como o aumento da produtividade interna, do número de empregos, entre outras. Os cartéis de exportação mistos, por outro lado, podem trazer algum tipo de restrição concorrencial, que deverá ser avaliada cuidadosamente pelas autoridades antitrustes ${ }^{116}$. Quanto aos consumidores internacionais, o prejuízo não é certo. Muito ao contrário, podem até mesmo se beneficiar da presença de um outro agente econômico a oferecer-lhes produtos nesse concentrado mercado. Essas questões serão mais bem debatidas ao longo do Capítulo 4.

Há ainda um outro ponto de diferenciação, da maior relevância - ao contrário dos cartéis tradicionais, normalmente condenados pelas legislações concorrenciais, as associações para exportação não são constituídas à margem das leis nacionais: eles existem com a ciência (ou ao menos com a permissão, ainda que tácita), dos governos dos locais nos quais se originam. Isso quer dizer que um cartel de exportação formado sobre os auspícios do Webb-Pomerene Act não pode ser entendido da mesma forma que o cartel internacional das vitaminas ${ }^{117}$, dado que existe uma permissão legal do governo americano para que o acordo entre as empresas exista. Verificaremos ainda nesse Capítulo que, em alguns casos, a iniciativa de constituição dessas associações parte dos próprios Estados, interessados em uma forte atuação de suas empresas no mercado internacional.

A despeito de parecer claro o abismo entre as atividades dos dois tipos de acordos entre concorrentes, é comum o esforço para que sejam confundidos. A aproximação permitiria que a prática fosse mais facilmente disciplinada, o que estaria em linha com

\footnotetext{
116 Faremos referências aos cartéis de exportação mistos e puros no item 4.1.

117 A respeito desse famoso acordo entre concorrentes afirma a Secretaria de Direito Econômico: "Entre 1989 e 1999, as oito maiores empresas fabricantes de vitaminas (incluindo BASF, Hoffman-La Roche, Aventis e Solvay) dividiram o mundo em regiões de atuação e fixando artificialmente os preços de vitaminas como A, B, C e E. O CADE, após investigação da SDE, puniu a conduta em 2007 em quase R \$15 milhões. O mesmo cartel já sofreu multas de mais de US\$2 bilhões em outros países" (Disponível em http://www.mj.gov.br/data/Pages/MJ9F537202ITEMID64C7E5D5CC8348F3A76D418F2746CAAFPTBRIE .htm, acesso em 12 out. 2009).
} 
inúmeros interesses, inclusive o de uniformização das legislações concorrenciais, a serem estudados no Capítulo 5.

Para a análise das questões que emergem da utilização das associações para exportação serão utilizados três Capítulos deste estudo. O primeiro deles será introdutório e trabalhará com as classificações encontradas na doutrina e com os benefícios e malefícios usualmente elencados pelos estudiosos. Os Capítulos 4 e 5 serão responsáveis pela análise das polêmicas que envolvem a sua utilização e pela verificação de como elas são tratadas na experiência internacional.

\subsection{Classificações e formas de isenção}

Os cartéis de exportação podem ser constituídos de diversas formas, a depender das necessidades encontradas pelos exportadores para a colocação de seus produtos no mercado externo. Assim, se o problema é a falta de informações sobre a dinâmica concorrencial a ser enfrentada, a associação pode servir como fonte para que os agentes troquem esses conhecimentos e tenham melhor munição. Caso a questão seja ligada às altas despesas de marketing, os produtores podem dividir esses custos, tornando-os suportáveis. Já se o problema for a concorrência desenfreada por preço, podem se reunir e estabelecer um preço base. Como se vê, a diversidade das situações negociais possibilita que inúmeros arranjos sejam possíveis. Os principais tipos de acordos efetuados entre concorrentes são os seguintes:

i) o ajuste dos preços: impede que a concorrência entre os produtores se dê com relação ao preço cobrado dos compradores estrangeiros;

ii) a divisão territorial dos mercados: permite que os exportadores desenhem áreas especificas para a atuação de cada um dele. Dessa maneira, evitam que seus produtos concorram uns com os outros em locais pré-determinados, transformando cada um dos exportadores em "monopolistas" nas suas respectivas áreas;

iii) o estabelecimento de políticas comuns de exportação: os membros do acordo acertam formas similares de realizar as vendas, impedindo que esse seja um fator de diferenciação entre eles (exemplo: prática dos mesmos prazos para pagamento, das mesmas taxas de juros e de condições similares de crédito); 
iv) o estabelecimento de padrões comuns para os produtos a serem ofertados: como se observou no Capítulo 3, o objetivo da padronização é tornar o bem indiferente aos olhos daqueles que o adquirem. Dessa forma, é igual para o consumidor adquirir os seus produtos do fornecedor $\mathrm{A}$ ou $\mathrm{B}$, que acabam sendo vistos como um único agente econômico $^{118}$;

v) acordos para divisão dos custos de exportação: os custos adicionais existentes para a colocação do produto no mercado externo, como aqueles relacionados ao frete, impostos, marketing, etc. são divididos entre os membros do acordo, o que lhes garante uma posição mais competitiva no mercado (ou seja, podem praticar preços menores no mercado ou simplesmente auferir maior proveito econômico com as transações);

vi) acordos para a negociação conjunta com os compradores: o objetivo dessa medida é fazer com que as empresas tenham maior poder de barganha do que teriam em negociações realizadas individualmente;

vii) acordos para a troca de informações sobre o mercado e sobre os compradores externos: espera-se que um grupo de empresas obtenha dados mais rapidamente e com maior precisão se comparado àqueles que seriam coletados por cada empresa isoladamente;

viii) outros.

A Organização para a Cooperação e Desenvolvimento Econômico - OCDE relata que as associações para exportação podem ainda se diferenciar pela existência ou não de uma associação por meio da qual as empresas partes do conluio operam ${ }^{119}$.

\footnotetext{
118 "The multidimensional nature of international competition, in which non-price aspects are as important as the price dimension, makes this argument crucial for export cartels. A related predisposition of a market to effective cartelization is the homogeneity of the product. If a commodity is homogeneous, it is easier to reach agreement on the price to be set" (LESTER G. TELSER, Competition, collusion and game theory, Chicago, Aldine Atherton, 1972, p. 180).

119 "Forms of organization of export cartels seem to vary widely between Member countries. While in the United States and in the Federal Republic of Germany in most cases there are no special organizations but mere co-ordination of export activities, the form normally adopted, in Spain, is the stock company. In the Netherlands, 14 of 20 existing export cartels operate through special organizations, ten of which have been established outside the trade associations. In the United Kingdom, members of 163 of the registered 288 export cartels operate indirectly through a special organization. Practice is equally different with regard to
} 
Podemos ainda pensar em outras subdivisões e classificações para melhor compreensão dos cartéis de exportação. Com relação à nacionalidade de seus membros, as associações para exportação podem ser formadas unicamente por empresas de um mesmo país ou por empresas de origens diversas (ou seja, pertencentes a mais de um país).

A classificação mais importante relaciona-se ao local no qual os efeitos das atividades da associação para exportação podem ser percebidos. Podemos encontrar cartéis de exportação cujos efeitos: (i) são sentidos em mais de um país, incluindo aquele no qual o acordo foi planejado; e (ii) são sentidos apenas fora do país no qual o acordo foi planejado $^{120}$.

A doutrina convencionou denominar cartéis de exportação puros os que atuam apenas no mercado internacional (ou seja, aqueles cujos reflexos são percebidos unicamente fora do Estado que permite o conluio). São essas as associações geralmente admitidas pelas legislações, visto que o acordo deve envolver apenas a atividade de exportação. Por oposição, os cartéis de exportação mistos são aqueles que atuam no mercado internacional e no mercado interno, sendo raramente admitidos pelas legislações concorrenciais. Quando o são, é comum o que o Estado exerça forte controle sobre as suas $\operatorname{atividades}^{121}$.

Uma questão bastante importante (e controversa) é como os Estados autorizam que suas empresas se engajem em um cartel de exportação. Basicamente, isso pode ocorrer de duas formas: o Estado explicitamente permite o manejo desses instrumentos (as chamadas isenções explícitas) ou, em vez disso, pode simplesmente se calar a esse respeito (as chamadas isenções implícitas). Dentro das primeiras, encontramos ainda dois modelos de

selling. In the United States it is estimated that in 95 per cent of the cases members deal directly with their costumers rather than through the association; most of the special organizations perform only minor functions for their members: maintenance of trade marks, collection of market information, etc. Similarly, in the Federal Republic of Germany, export cartels have established joint sales corporations in only six cases, some of which, however, sell only to some export markets, while, in other markets, the cartel members deal directly with their customers on the basis of agreed prices, conditions, quotas, etc" (OECD, Export Cartels, Report of the Committee of Experts on Restrictive Business Practices, Paris, 1974, p. 30).

120 Obviamente, aqui não há que se falar em efeitos sentidos unicamente no país no qual o acordo foi estabelecido, visto se tratar de acordos para a exportação.

$121 \quad$ “'Pure' export cartels are defined as cartels which cover exclusively competition on foreign markets, while 'mixed' export cartels affect competition both on foreign and domestic markets" (OECD, op. cit., p. 7). 
permissão: i) países que exigem notificação expressa sobre a sua constituição $^{122}$; e ii) países que não exigem qualquer tipo de notificação ao governo.

A isenção explícita ocorre sempre que há autorização expressa para a criação dos cartéis de exportação. A anuência pode constar da legislação concorrencial ou de um ato da autoridade competente. Essa é a forma mais "corajosa" de enfrentar o problema, visto que o Estado admite, textualmente, a sua concordância com a utilização desses instrumentos. Por ser uma declaração formal, ela é transparente e elogiada pela literatura especializada. Esse é o posicionamento adotado pelos Estados Unidos, que admite o uso das associações para exportação por meio do Webb-Pomerene Act.

Como afirmamos, esse tipo de autorização comporta ainda uma subdivisão: podemos separar os países entre aqueles que exercem algum tipo de controle sobre as empresas que se valem dos cartéis de exportação (os Estados Unidos, por exemplo, exigem o registro junto à Federal Trade Commission) e aqueles que mantêm a autorização expressa, mas não possuem controles formais sobre as empresas que deles se valem.

Essa subdivisão, que a princípio pode parecer de menor importância, é fundamental para que possamos analisar os parcos estudos encontrados sobre o tema deste trabalho: eles se tornam mais ou menos confiáveis de acordo com o tipo de isenção concedida. Nas situações nas quais o governo não obriga o registro, o número de cartéis declarados pode mascarar sua real utilização (afinal, que incentivo um agente teria para se declarar membro de um cartel se não há nenhuma obrigação legal para tanto?) ${ }^{123}$. A desnecessidade de qualquer tipo de declaração, na verdade, acaba por mitigar parte dos benefícios advindos da autorização explícita, na medida em que, ao final, o estudioso saberá apenas que os cartéis de exportação são permitidos em determinado ordenamento, mas não conseguirá mensurar sua real utilização. Nesse sentido, MARGARET C. LEVENSTEIN e VALERIE Y. SUSLOW afirmam que os efeitos das associações para exportação são facilmente perceptíveis quando o registro é exigido, já nos países em que isso não ocorre, os dados sobre a sua utilização são questionáveis.

122 "Some countries (including the United States and Australia) are, however, concerned that competition-reducing spillover effects be avoided in domestic markets, and require some sort of registration and disclosure of the arrangement" (MARGARET C. LEVENSTEIN e VALERIE Y. SUSLOW, op. cit., p. 791).

123 MARGARET C. LEVENSTEIN e VALERIE Y. SUSLOW, op. cit. 
A outra modalidade de isenção para as associações para exportação é conhecida como isenção implícita. Ocorre quando as leis antitruste não prevêem expressamente a proibição ou permissão para a sua utilização, ou seja, não enfrentam diretamente o problema da licitude ou não de seu manejo. Por não proibirem textualmente a prática, entende-se, por via reversa, que autorizam a sua utilização, visto que a lei concorrencial apenas se aplicaria àquelas práticas cujos efeitos são sentidos em seu território. Trata-se de uma modalidade de isenção ainda mais sutil do que a isenção explícita sem a necessidade do registro, sendo uma posição bastante confortável para os Estados, que simplesmente não se manifestam sobre o tema ${ }^{124-125}$.

A advertência acima referida torna-se mais importante quando tratamos dessa modalidade de isenção (a implícita): aqui não há sequer a declaração oficial por parte dos Estados de que os cartéis de exportação são permitidos. Dentro dessa realidade, como analisar confiavelmente qualquer estudo numérico sobre esses institutos? Dados mais confiáveis somente seriam obtidos caso fossem adotadas as isenções explícitas e houvesse a necessidade do registro.

A esse respeito, a Organização para a Cooperação e Desenvolvimento Econômico OCDE se manifestou em 1974 sobre os cartéis de exportação em 19 países: "Only four countries (Germany (1), Japan, United Kingdom, United States) require notification of 'pure' export cartels. Only these four countries do the authorities therefore have information about the extent of cartelization in their export trade. Naturally, it cannot be said with absolute certainty whether this information is complete, particularly as regards those countries where no legal sanctions are attached to the failure to notify. In the

124 "Holmes et al. (2003, p. 69) remind us that 'Domestic competition laws are jurisdictional with regard to effects on the domestic territory... As such, they act to address both foreign and domestic practices, but only as these practices affect competition upon the domestic market. Since national competition laws are not drawn to treat the external... effects of domestic policies, territories stating explicit 'exclusions' from treating the external effects of domestic practices (export cartels) are really no different from the territories that do not state such an explicit exclusion" (ADITYA BHATTACHARJEA, Export cartels, a developing country perspective, cit., p. 3).

125 Nas palavras de SPENCER WEBER WALLER: "Most countries simply take the position that their own competition laws do not extend to export activities, and as a result, require little or no reporting of export cartels. For countries that are members of the Organization for Economic Co-Operation and Development ('OECD'), only Japan, Germany, the United Kingdom and the United States have mechanisms for registering export agreements. Even this data can be deceiving given the fact that there may be no requirement of compulsory notification when export agreements are abandoned and no requirements for reporting export cartels or agreements which do not include any restrictions on domestic commerce. Information about export cartels for other OECD countries is very limited and is almost non-existent for countries outside the organization" (Op. cit., p. 109-110). 
remaining 15 legislations the authorities have at best only fragmentary information about 'pure' export cartels"126.

Ainda sobre as discussões sobre a utilização dos cartéis de exportação, ULRICH IMMENGA nos traz outro elemento para questionamento ${ }^{127}$. Trata-se da possibilidade de responsabilização pessoal de agentes que adotam condutas restritivas à concorrência quando tais condutas forem admitidas por seus governos de origem.

Partindo para o tema específico deste estudo, a questão versa sobre a possibilidade de penalização do agente, caso venha a atuar em cartel de exportação, ainda que esse instrumento seja permitido pela legislação nacional.

ULRICH IMMENGA afirma que, na medida em que a ação dos agentes está de acordo com o quanto estabelecido por políticas do governo, tais ações estão relacionadas à soberania nacional, não devendo ocorrer a punição de seus participantes. Nesse caso, o autor está se referindo especificamente às ações governamentais que exercem poder de coação, exigindo que os sujeitos se comportem da forma previamente estabelecida.

No entanto, entende o autor que, no caso de as atividades derivarem unicamente de uma permissão governamental, ou seja, caso não exista obrigação para que ajam de determinada forma, poderia ocorrer responsabilização dos agentes perante a ordem internacional $^{128}$. Conforme se verá, esse entendimento já foi esboçado pela União Européia em julgamento de contenda com o Japão.

\footnotetext{
126 OECD, op. cit., p. 23. Observem-se, ainda, informações mais recentes: "Previous work identifies that 51 countries allow for export cartels either explicitly or implicitly in their antitrust regimes. In context, this is approximately half of the countries with antitrust regimes. Seventeen countries, including United States, maintain explicit exemptions. An additional thirty-four countries lack an explicit exemption. However, they maintain an implicit exemption because their domestic antitrust legislation limits the law's reach to the domestic market. In these settings, antitrust law implicitly allows for anticompetitive conduct entirely outside of the country's boards. Among this group of countries which implicit export cartels exemptions are nearly all EU members states" (DANIEL SOKOL, op. cit., p. 4).

127 Export cartels and voluntary export restraints between trade and competition policy, HeinOnline, 4 Pac. Rim L. Pol'y J. 93, p. 112, 1995.
} 


\subsection{Benefícios apontados}

As vantagens esperadas do uso dos cartéis de exportação parecem ser intuitivas, ainda mais se considerarmos que muitas delas são similares à obtidas pelos cartéis clássicos. Para esse estudo, vamos analisar com maior vagar quatro benefícios, que demonstram a importância desses instrumentos para o fomento das exportações e o benefício que podem trazer para os consumidores estrangeiros. São eles: i) a diminuição dos custos de exportação e o conseqüente estímulo para que as empresas de determinado país possam ser competitivas diante das estrangeiras; ii) o aumento do poder de barganha dos exportadores em face dos compradores internacionais; iii) o desestímulo à concorrência ruinosa entre os exportadores; e iv) o nascimento de um novo competidor no mercado externo ${ }^{129}$.

\subsubsection{Diminuição dos custos de exportação e estímulo à competitividade}

O processo de produção e colocação de qualquer bem no mercado envolve uma série de custos. A necessidade de exportação agrega a esse processo novas etapas que acabam por torná-lo mais complexo e, por vezes, encarecem-no ${ }^{130}$. Como exemplo desses custos adicionais, podemos pensar nos relativos a transporte, frete, seguros, desembaraço, intermediários no país de origem e de destino, variações de câmbio, marketing, negociação de contratos internacionais, entre outros. Todos esses fatores colocam o produtor nacional em posição desvantajosa em relação ao estrangeiro.

A diluição desses custos foi, sem sombra de dúvidas, uma das motivações para que se editasse nos Estados Unidos o Webb-Pomerene Act. Nas palavras da Comissão

129 A OCDE, apontando os proveitos que seriam esperados com a adoção dos cartéis de exportação nos Estados Unidos, identifica os seguintes pontos: "The costs of exporting would be reduced either by spreading overhead and eliminating duplicate Sales organizations, or by obtaining lower rates on export services such as insurance and freight, or by increasing the line merchandise offered for export. Groups of relatively smaller scale American producers would more readily be able to enter into and survive in foreign markets in the face of powerful combinations because of their reduced export costs and increased financial resources supporting export programs. Higher prices and improved sales terms generally would be obtained from foreign buyers, especially those organized into buying cartels, due to the elimination of competition among American firms. Lower shipping rates and other export service charges would be obtained due to the organized and concerted effort of the associations" (OECD, op. cit., p. 47).

130 Aqui não estamos fazendo análise sobre serem esses custos maiores ou menores. Apenas afirmamos que existem custos específicos incorridos por aqueles que pretendem comercializar fora de seu país. 
responsável pelo projeto de lei: "If Americans are to enter the markets of the world on more nearly equal terms with their organized competitors and their organized costumers, and if small American producers and manufacturers are to engage in export trade on profitable terms, they must be free to unite their efforts. Without any export organization, foodstuffs and raw materials can readily be sold at some price, but to avoid needless expense in distribution, to meet formidable foreign buying organizations, and to insure profitable export prices, cooperation among American producers if such commodities is desirable. In the sale of factory products, cooperation is even more desirable. Such goods must be advertised, demonstrated and market created abroad, often in the face of the keenest competition from great combinations of foreign manufactures"131.

Além das etapas extras para a comercialização, os ensinamentos trazidos pela Nova Economia Institucional demonstram a existência de outros tipos de dificuldades a serem suportadas pelo exportador, relativas à insegurança para a realização de negócios em um ambiente desconhecido - são os chamados custos de transação. Imaginemos as diferenças entre as operações que ocorrem no comércio internacional e aquelas que ocorrem internamente: as trocas envolvem parceiros sujeitos a tradições e a legislações diferentes. A língua não é a mesma, os costumes também não são. A tendência, nesse cenário, é de que ocorra certa desconfiança, trazendo dificuldades para a coleta de informações e para a própria realização do negócio $^{132}$.

A falta de informações leva à maiores obstáculos para a elaboração dos contratos, elevando os custos para a realização dos negócios (por exemplo, é necessária a contratação

131 MILTON GILBERT, Export Prices and Export Cartels, New York, AMS Press, 1971, p. 116-117.

132 Os estudos econômicos tradicionais apenas se preocupavam com os custos de produção dos bens, ou seja, aqueles relativos aos insumos necessários para a sua produção. O artigo de RONALD COASE, "The Nature of the firm", abriu espaço para a discussão sobre os custos de transação, ou seja, aqueles necessários para a compra e venda dos ativos, tradicionalmente negligenciados por esses estudiosos. A demonstração de que não seriam desprezíveis, e que teriam vital importância na tomada de decisões dos agentes foi responsável pela abertura de um outro flanco de estudos, relacionados à Teoria dos Custos de Transação. PAULO FURQUIM assim os define: "Neste trabalho são apresentadas duas definições de custos de transação que parecem sintetizar as opiniões dos diversos autores. Em uma visão genérica os custos de transação são 'custos que são necessários para se colocar o mecanismo econômico e social em funcionamento' (Furubotn \& Richter, 1991: 3). Em outras palavras, são os custos não diretamente ligados à produção, mas que surgem à medida que os agentes se relacionam entre si e problemas de coordenação de suas ações emergem. A atividade econômica não se reduz à transformação tecnológica de insumos em produtos. [...] Atualmente os custos de transação são definidos não só pelo uso do mercado, mas pelo uso de qualquer forma organizacional, sendo o mercado um caso particular. A chave para se chegar a essa definição mais abrangente foi reconhecer que a firma é um complexo de contratos - e, portanto, transações, que também apresentam custos de funcionamento (ELIZABETH MARIA MERCIER QUERIDO FARINA, et al. Competitividade: mercado, Estados e organizações. FAPESP, 1997, p. 55-56). 
de assessoria jurídica especializada). Até mesmo a solução dos conflitos é alterada, recorrendo-se com freqüência a dispendiosas câmaras de arbitragem.

Podemos dizer que a segurança para a realização dos negócios internacionais é naturalmente inferior à esperada quando estes são realizados no âmbito nacional, o que muitas vezes se traduz na inviabilidade para os comerciantes colocarem seus produtos no mercado externo - isso é especialmente verdadeiro para as pequenas e médias empresas, com reduzido capital de giro ${ }^{133}$. Ainda que consigam exportar seus produtos, a existência desses fatores terá impacto sobre os custos e, por consequência, nos preços praticados (a tendência é de que custos mais altos levem a preços mais altos), o que torna os bens menos competitivos aos olhos dos consumidores.

A idéia que fundamenta a colaboração entre concorrentes é a redução dessas desvantagens. A coordenação permite a diluição dos gastos adicionais, tornando-os menos pesados para cada agente individualmente, da mesma forma, a atuação conjunta traz maior segurança para a atuação comercial em situações nas quais a negociação parece ser mais complicada. Dessa maneira, a autorização para a utilização dos cartéis de exportação nada mais é do que uma forma de tornar as empresas nacionais mais competitivas em relação às estrangeiras, beneficiando não só os agentes que são partes do acordo, como também ao seus países de origem (essa discussão já foi trazida no Capítulo 1).

Há ainda uma outra questão, que toca especialmente aos países em desenvolvimento. Trata-se da competição que ocorre entre as empresas pertencentes a esses países e aquelas originárias dos países desenvolvimento. Como é de se supor, aquelas provenientes de países periféricos, por maiores e mais bem sucedidas que possam ser, não são hábeis e lidar com o poderio econômico e marcário que caracterizam as empresas transnacionais, especialmente após a onda de fusões e aquisições que teve lugar na década de 1990. Nesse cenário, a competição "entre iguais" pode não ser viável, e os cartéis de

133 Sobre a importância da segurança e previsibilidade no tráfego mercantil, indispensável a leitura do artigo de PAULA A. FORGIONI: A interpretação dos negócios empresariais no novo Código Civil brasileiro, In Revista de Direito Mercantil, Industrial, Econômico e Financeiro, n. 130, ano XIII, São Paulo, Malheiros, abr.-jun. 2003, p. 7-38. 
exportação podem se tornar uma opção para que a concorrência possa ocorrer em bases mais equânimes ${ }^{134}$.

JOHN R. MAGNUS resume os benefícios: it "benefits exporters and their customers; it is a win-win proposition. The cost sharing and economies of scale achievable through joint marketing of exports often yield a dramatic savings. Companies serving international markets can reduce costs by pooling marketing expenses and sharing distribution infrastructure such as port facilities and ships. They can also share the cost of gathering and analyzing trade information concerning, for example, foreign credit and market conditions, transportation opportunities and shipping requirements. These reduced costs result in market growth and lower final costs to consumers around the world. Risk sharing is important as well, as many areas of the world are simply too risky for individual producers - particularly small firms - to make the sustained investments necessary to sell there. In emerging markets, political, credit, currency, regulatory and other risks often must be shared in order to be sustainable. Even setting aside governmental issues, the infrastructure necessary to deliver, unload, store, market and physically distribute a product in overseas markets can require a huge up-front investment unachievable for many companies"135.

$134 \quad$ "The analysis of the international merger wave also suggests another area of concern to the more advanced developing countries. This relates to the question of unequal competition between large multinational and big domestic corporations in these countries. Event he largest developing country corporations tend to be much smaller than the industrial country multinationals. The large merger wave of the 1990s is likely to make this disparity even bigger. By means of worldwide mergers and tie-ups, the advanced country corporations are able to integrate their international operations. This may be a source of genuine technical economies of scale, but evidence indicates that in most industries average cost curves are L-shaped, that is to say, after a threshold size which is relatively small and which most of these giant corporations would already have achieved even before mergers, costs do not fall as the size of the firm increases. The economies which nevertheless the multinationals are able to achieve through integration are those relating to bulk buying of inputs, reduced cost of capital due to large size as well as economies achieved advertising and other marketing activities on large scale. To the extend that these economies depend on the market power of the multinational in relation to inputs, the cost saving measures are not necessary welfare enhancing, furthermore, these 'pecuniary economies' create barriers to entry which make the markets less contestable" (Competition Policy, development and developing countries, cit., p. 6).

135 Joint Export Trade Provisions in Antitrust Laws: A Supporter's Perspective, In Journal of World Trade 39 (1), 2005, p.182. 


\subsubsection{Aumento do poder de barganha}

A segunda vantagem trata do aumento do poder de negociação adquirido por meio das associações para exportação. Usualmente, os exportadores são pequenos agentes econômicos, se comparados às empresas que adquirem seus produtos. Por essa razão, não conseguem impor muitas condições para a realização de seus negócios: ao contrário, ou acatam o preço e condições estabelecidas pelas grandes corporações ou ficam fora do negócio. Trata-se, não raras vezes, de mero contrato de adesão. Para ilustrar a situação, podemos pensar em uma empresa produtora de cafés especiais que negocia com um grande comprador estrangeiro, como a Nestlé.

É certo que a união dos pequenos players resultará em uma elevação no poder de negociação com a transnacional, se comparado com aquele que seria exercido caso cada um deles comercializasse isoladamente. Com a união, ou a compradora se dispõe a sentar à mesa para negociar com os cafeicultores ou não poderá comprar de nenhum dos membros do acordo.

A importância do poder de barganha se revela fundamental quando constatamos que existem no mercado internacional grandes barreiras ao comércio de produtos estrangeiros, sejam elas tarifárias ou impostas pelas próprias empresas e governos estrangeiros. Nessa esteira, podemos pensar em cotas de exportação, exigências de documentação e de condições fitossanitárias. Além disso, não é raro que os consumidores estrangeiros realizem suas compras em bloco, fenômeno conhecido pela doutrina como cartel de compra. Nesses casos, as dificuldades encontradas são contrabalanceadas pelo poder que é congregado pela associação para exportação ${ }^{136}$.

\footnotetext{
136 Afirma FLORIAN BECKER: “The U.S. in particular justifies this leniency towards export cartels by the aim of increasing efficiency in target markets that are suffering from high entrance barriers for importers" (The case of export cartel exemptions: between competition and protectionism, In Journal of Competition Law and Economics, 3 (1), p. 97). Com efeito, uma das justificativas para a edição do WebbPomerene Act foi a existência de poderosos cartéis de compra: "The Commission's report also stated that American exporters were in many countries selling to buying combinations or cartels: In various markets, American manufactures and producers deal with highly effective combinations of foreign buyers. Thus exporters of lumber find such combination in Australia and on the continent of Europe. Cotton seed products are handled by combinations of buyers in Holland, Denmark, and Germany; and Austrian cotton-textile manufactures have a buying combination to import their raw cotton. The Cooperative Wholesale Society, Ltd., an astonishingly comprehensive wholesale buying organization maintained by 1,400 cooperative societies in Great Britain, has one buyer in New York who annually purchases millions dollars' worth of American products. [...] These combinations naturally make individual American producers bid against each other, and are thus able to buy at comparatively low prices. According to the president of one of the largest American copper companies, the German metal-buying combination, by such tactics as these and by the
} 
ALBERTO SALAZAR VALLE, ao incentivar a atividade conjunta de pequenas empresas, afirma: "A idéia [...] é substituir a negociação individual pela coletiva. 'Assim, as pequenas tendem a se fortalecer e a obter condições de encarar situações que lhe são adversas' [...]. Entre os problemas freqüentemente enfrentados por essas corporações estão o cancelamento de pedidos à última hora e o atraso nos pagamentos por parte das grandes empresas" $" 137$.

\subsubsection{Desestímulo à concorrência ruinosa}

O terceiro benefício a ser discutido é o desestimulo à concorrência desenfreada entre os exportadores ${ }^{138}$. Observamos no Capítulo 3 que a concorrência pode ser benéfica ao consumidor, trazendo-lhe inovações tecnológicas, aperfeiçoamento dos bens e preços mais baixos. Ocorre que, em alguns mercados, e particularmente nos perfeitamente competitivos, a disputa entre os agentes se dá unicamente por meio do quesito preço. Embora tal rivalidade possa ser interessante para o consumidor no curto prazo, dada a possibilidade de pagar o menor preço pelos produtos adquiridos, ela pode ser, ao longo do tempo, ruinosa para os agentes econômicos e trazer problemas para os próprios consumidores.

Vamos nos utilizar do mesmo exemplo acima para entender como isso ocorre. Os cafés verdes oferecidos pelos cafeicultores brasileiros não apresentam diferenciações entre si (nesse sentido, são commodities). Assim, para a Nestlé (ou para qualquer outro comprador) é indiferente adquiri-lo da fazenda A ou B, tendo em vista que o produto final não será modificado pela escolha de um ou outro fornecedor. Caso essas fazendas estejam

manipulation of the foreign future markets, has bought millions of tons of American copper at prices averaging, over a series of years, nearly a cent a pound bellow the prices paid by American costumers" (MILTON GILBERT, op. cit., p. 116).

137 Exposição durante o seminário “Os desafios do crescimento durante o século XXI”, realizado nos dias 6 e 7 de dezembro de 2004 na Universidade de Campinas, (MANUEL ALVES FILHO, Novas pautas para os desafios do desenvolvimento, disponível http://www.unicamp.br/unicamp/unicamp_hoje/ju/dezembro2004/ju276pag05.html, acesso em 27 ago 2009).

138 Apesar de algumas divergências, o fenômeno tem correspondência na língua inglesa, sendo denomiando cutthroat competition "Competition is cutthroat when an industry experiences subnormal earnings over a considerable period. This situation arises when excess capacity coincides with inability of producers to control production and prices" (LLOYD G. REYNOLDS, Cutthroat competition, In The American Economic Review, v. 30, n. 4, Dec. 1940, p. 736). 
negociando individualmente com a transnacional, há grandes chances de entrarem em desabalada concorrência por preços, oferecendo a ela preços cada vez mais irrisórios. A disputa pode chegar a tal nível que o comércio do café não será mais lucrativo para nenhuma delas.

Nesse caso, a Nestlé terá o benefício de pagar uma quantia ínfima pelo produto (ou seja, sairá ganhando), mas os dois produtores nacionais sairão bastante enfraquecidos, porquanto: i) provavelmente apenas uma delas conseguirá fornecer café para a transnacional; e ii) o custo dessa "vitória" será muito alto, uma vez que o produto foi comercializado a preço bastante inferior do esperado. A concorrência sem limites pode até mesmo levar à ruína dos agentes econômicos, que muitas vezes não recebem dos compradores valor suficiente para a manutenção de suas atividades. Vencem a disputa, mas não levam as batatas.

Embora o consumidor possa se beneficiar momentaneamente dessa "briga" (pois os produtos poderão ser-lhes oferecidos a preços menores) devemos avaliar como essa luta se reflete no longo prazo. Ou seja, é necessário analisar o problema com olhar mais criterioso e não nos deixarmos levar pela visão pela qual o nível de concorrência no mercado deve ser sempre o maior possível. Com efeito, a depender do mercado do qual estamos tratando, isso pode não ser uma realidade, especialmente para os países em desenvolvimentos, nos quais muitas vezes é necessário que os níveis de competição sejam controlados para que as empresas nacionais possam se estabelecer e atingirem níveis de lucro que permitam a permanência da atividade. Com efeito, dentro de sua política, o Estado deve buscar boas oportunidades de lucro que estimulem os empresários a investir e inovar ${ }^{139}$.

Não é raro que o malefício da competição exacerbada transcenda a esfera privada e atinja a pública, já que a falência das empresas pode levar ao desemprego, a menor volume de impostos recolhidos, a menores divisas geradas, entre outros fatores. A ruína é

$139 \quad$ "This suggests that unfettered competition may not be appropriate for a developing economy. Economic theory as well as experience indicates that, in the real world of incomplete and missing markets, unfettered competition may lead to price wars and ruinous rivalry and therefore may be inimical to future investment: from this perspective, too much competition can be as harmful as too little. What is required by developing economies is an optimal degree of competition which would entail sufficient rivalry to reduce inefficiency in the corporate use of resources at the microeconomic level, but not as much competition that it would deter the propensity to invest. This central analytical point is altogether ignored in competition policy discourse in countries such as the US where the concept of optimal degree of competition is simply assumed to be maximum competition, that is, the more competition the better". (AJIT SINGH; RAHUL DHUMALE, Competition policy, development and developing countries, Trade-Related Agenda, Development and Equity Working Paper, South Centre, November, 1999, p. 12). 
especialmente provável para os agentes de menor fôlego econômico, como as pequenas e médias empresas. É de interesse não somente das empresas, mas também dos próprios Estados que os efeitos da concorrência sejam cuidadosamente avaliados ${ }^{140-141}$.

É necessário notar que alguns doutrinadores posicionam-se expressamente contra a possibilidade de acordo entre os agentes para evitar a concorrência desenfreada. Para eles, a manutenção da competitividade da indústria nacional não justificaria a atuação conjunta, pela possibilidade de essas empresas virem a controlar a economia dos países ${ }^{142}$.

\subsubsection{Nascimento de um novo competidor no mercado externo}

Um último benefício que analisaremos (e não por isso menos importante) é o surgimento de novos competidores na arena internacional. Como já observamos, os cartéis de exportação, por permitirem a divisão de custos e por fortalecerem as empresas no comércio internacional, viabilizam a atividade de muitos produtores que, sozinhos, jamais atingiriam esse objetivo.

Com o usual preconceito com que são tratados os acordos entre concorrentes, soa de certa forma estranho afirmar que um cartel terá o condão de tornar o mercado

140 PAULA A. FORGIONI revela outro aspecto perigoso da busca infindável por oferecer preços mais baixos: "[...] a concorrência tende a diminuir os preços praticados no mercado, impelindo o agente eficiente à redução dos custos para evitar demasiado sacrifício do seu lucro. Ocorre que, em alguns segmentos, a excessiva pressão pela diminuição dos custos mostra-se perigosa, porque pode levar o agente econômico ao desprezo de aspectos socialmente relevantes, como a segurança para o adquirente ou a qualidade dos produtos. Ademais, a obtenção de um lucro maior (que seria impossível em um mercado concorrencial) pode significar a sobrevivência de um setor ou mesmo a manutenção de empregos" (Os fundamentos do Antitruste, cit., p. 211).

141 Nesse passo, devemos observar os ensinamentos de LUIZ CARLOS BRESSER-PEREIRA: "A nação envolve uma solidariedade básica entre as classes quando se trata de competir internacionalmente. Empresários, trabalhadores, burocratas do Estado, classe média profissional e intelectuais podem entrar em conflito entre si, mas sabem que têm um destino em comum, e que este depende de seu êxito em participar de forma competitiva no mundo dos Estados-Nação. Envolve, portanto, um acordo nacional, o contrato social básico que dá origem à nação e a mantém forte e coesa. É o grande acordo entre as classes sociais de uma sociedade moderna que permite que essa se transforme em uma verdadeira nação, ou seja, em uma sociedade dotada de um Estado capaz de formular uma estratégia nacional de desenvolvimento" ( $O$ novo desenvolvimentismo e a ortodoxia convencional, São Paulo em Perspectiva, São Paulo, Fundação Seade, v.20, n.3, p. 1, jul./set. 2006, disponível em http://www.seade.gov.br, acesso em 26 ago. 2009).

142 "Falências e desemprego causados por preços vis que resultam de uma concorrência ruinosa, não podem ser evitados legitimamente através de atos das empresas atingidas que visam restringir esta concorrência. Considera-se que estes males são preferíveis aos que podem resultar da entrega a particulares do poder de controlar significativamente a vida econômica do país, por meio de restrições da concorrência". SHIEBER, op. cit., p. 95. 
internacional mais saudável, mas trata-se da verdade. O cartel de exportação não é necessariamente um instrumento anticompetitivo para os consumidores internacionais, na medida em que habilita novos produtores a se juntarem ao comércio - os que não podiam comercializar sozinhos podem fazer isso por meio da associação.

Essa maior diversidade de fornecedores pode ser bastante benéfica aos consumidores. Na síntese da Organização para a Cooperação e Desenvolvimento Econômico - OCDE: “[...] export cartels also have important international aspect. In the international setting they may be beneficial if they are formed by small or medium-sized firms which are thereby permitted to participate in export trade and to promote international trade (however, mention must be made of the fact, as noted above, that the typical firm benefitting from the exemption for export cartels in the United States and Germany is not the small or medium sized firm)" ${ }^{143}$.

Há um outro ponto a ser observado: em um ambiente comercial dominado por transnacionais e conglomerados industriais, no qual não há espaço para pequenos e médios produtores, é bastante difícil sustentar que é a criação de um cartel de exportação que irá tornar o mercado concentrado ou anticompetitivo ${ }^{144}$.

\subsection{Malefícios apontados}

Tendo sido analisadas as benesses esperadas com os cartéis de exportação, partiremos para o estudo de seus malefícios. Sistematizando as discussões trazidas pela doutrina, podemos dividi-las em três grandes grupos: i) a possibilidade de atuação do cartel de exportação em atividades outras que não a exportação; ii) o desincentivo para a

\footnotetext{
$143 \quad$ OECD, op. cit., p. 50.

144 "Da integração de empresas pode decorrer a concentração do mercado, o que não significa dizer que, necessariamente, da integração de empresas sucederá um mercado concentrado. O mercado concentrado é aquele no qual um pequeno número de empresas é responsável por um alta proporção do faturamento da indústria. A concentração, portanto, diz respeito ao numero de empresas que participam do mercado e às respectivas participações relativas" (JOSÉ MARCELO MARTINS PROENÇA, Título VII das formas de controle, Capítulo I - Do controle de atos e contratos, cit., p. 380).
} 
construção de uma "política internacional da concorrência"; e iii) os reais destinatários. Analisemos cada um deles ${ }^{145}$.

\subsubsection{Utilização do cartel de exportação em atividades outras que não a exportação}

O primeiro grupo de críticas se concentra na possibilidade de as empresas se utilizarem dos benefícios trazidos pelas associações para exportação para atividades diversas da colocação de seus produtos no mercado internacional. A grande preocupação, sem dúvida, é a utilização desse benefício no mercado interno do país autorizante.

Como já foi observado, esses instrumentos são admitidos (e se justificam) na medida em que mitigam as adversidades encontradas no comércio internacional. Dessa forma, é evidente que o estímulo se restringe à atuação nesse âmbito - não podendo se tornar, de forma alguma, autorização para que se constitua um cartel clássico ${ }^{146}$.

Ocorre que - afirmam os defensores dessa teoria - é impossível controlar a forma como ocorre o intercâmbio de informações entre as empresas, garantindo que a atividade conjunta se restrinja a assuntos internacionais. Para tanto, seria necessário que se construíssem controles rígidos das informações trocadas, o que seria bastante improvável, tendo em vista a forma dinâmica como transcorre a atividade comercial ${ }^{147}$. O argumento é

145 BRENDAN J. SWEENEY nos traz um sumário dos possíveis problemas: "Although the empirical evidence against export cartels is lean, commentators have pointed to a number of negative indirect effects that are Said to justify some concerted action. First exempting export cartels provides foreign buyers with incentive to form buyers' cartels retaliation. Secondly, where an export cartel comes into existence, producers in the export country who are not members of the cartel have strong incentives to seek membership of the cartel. The strengthens and perpetuating the cartel. Thirdly, export cartels promote international cartels (made up of a number of export cartels).. An international cartel formed from a number of export cartels is likely to be more stable than other international cartels which do not have the advantage of receiving state support. Fourthly, because the import state may seek to use its competition law extraterritorially against the export cartel and because the exporter's government has incentives to protect the export cartel and because the export cartel will normally only be able to argue the doctrine of state compulsion if its own government has compelled, not just encouraged the cartel, the export government has an incentive to move towards compulsion (not just toleration) of export cartels. This increase the danger of trade conflicts" (Global competition: searching for a rational basis for global competition rules, 30 Sydney L. Rev. 209, 2008, p. 224-225).

146 Considerando-se o caso dos cartéis de exportação puros. Quanto aos mistos, o controle do governo costuma ser bastante rígido para evitar problemas internos.

147 A OCDE assim explica o problema: "Export cartels frequently also restrain domestic competition, even if there is an explicit clause in the cartel contract that no internal effects are intended (so-called 'pure' export cartels). It is easy to conceive that the efforts to achieve a common export policy and the exchange of information on prices, costs, production lines, capacities, sales policies, etc. may influence the domestic 
sustentado por A. Paul Victor: "[...] experience teaches that there are often anticompetitive spillover effects from export cartels into the domestic market. Once competitors are allowed to join for overly anticompetitive purposes in foreign markets, it is not surprising to find that the attractions of covert collaboration are too great to resist at home" ${ }^{148}$.

Com efeito, não há como negar que a autorização governamental pode ser elemento facilitador para que alguns agentes ultrapassem os limites e partam para atividade não abarcada pela isenção concedida aos cartéis de exportação. A despeito dessas ponderações, no entanto, é de se observar que o risco de os concorrentes virem a trocar informações indevidas é permanente. Tanto assim que, diariamente, vemos o desmantelamento de cartéis em países nos quais não há que se falar na autorização para os cartéis de exportação. Ademais, no ordenamento jurídico brasileiro, a atividade conjunta de concorrentes já é admitida, o que ocorre, por exemplo, com as joint ventures. Nos cartéis de exportação, teríamos o mesmo tipo de situação; a diferença estaria no fato de se tratar de operação conjunta para atuação no mercado externo ${ }^{149}$.

Uma forma de mitigar o risco seria estabelecer com clareza os limites existentes para a atuação conjunta e o tipo de informação que poderia ser comungado pelas empresas, o que traria maior grau de segurança para os agentes econômicos e para as próprias autoridades concorrenciais.

competitive conduct of the participating forms. (1) Thus, the 'side effect' of most pure export cartels may be a restraint of domestic competition mainly through conscious parallelism” (OECD, op. cit., p. 50).

148

Op. cit., p. 577.

149 Na ponderação de ROBERT H. BORK, que relata a proximidade das joint ventures com o acordo entre concorrentes: "Many people seem to think that the formation of a partnership or joint venture somehow does not involve an agreement on prices and markets. Yet many partnerships rely upon just such agreements, and we recognize their economic utility. The typical law partnership provides perhaps the most familiar example. A law firm is composed of lawyers who could compete with one another byte ho have instead eliminated rivalry and integrated their activities in the interest of more effective operation. Not only are partners and associates frequently forbidden to take legal business on their own [...], but the law firm operates on the basis of both price-fixing and market-division agreements. The partners agree upon the fees to be charged for each member's and associate's services (which is price fixing) and usually operate on a tacit, if not explicit, understanding about fields of specialization and primary responsibility for particular clients (both of which are instances of market division). Nobody supposes that a law firm in New York fixes fees or controls specialization and clients contracts for the purpose of restricting output. Each firm faces the rivalry of scores of hundreds of others firms, so that output restriction is not tenable hypothesis. The alternative hypothesis is that the partners believe the agreement make the firm more efficient. We have, therefore, a very common situation in which agreements fixing prices and dividing markets contribute to efficiency and certainly should not be illegal" (Op. cit., p. 263-265). 


\subsubsection{Desincentivo para a construção de uma "política internacional da concorrência"}

O segundo grupo de argumentos a sustentar a impossibilidade de utilização dos cartéis de exportação trata da oposição que existe entre a utilização desses instrumentos e a construção de uma "política internacional da concorrência".

Este tópico, por muito importante e conflituoso, será tratado ao longo de todo o Capítulo 5. Por ora, podemos afirmar que a visão dos clássicos, segundo a qual o comércio internacional operaria com maior eficiência caso fossem adotadas regras universais de livre concorrência e livre mercado, leva à perseguição da uniformização das condutas dos países, sempre tendo em vista tais ideais. Caso fossem adotados esses padrões comuns de comportamento, seria garantido o aumento na oferta de produtos à disposição dos consumidores, a maior competição entre os agentes econômicos, as economias de escala, de escopo e preços mais competitivos, entre outros.

Uma forma encontrada para que esse modelo fosse adotado com maior facilidade seria a criação de uma "política internacional de concorrência", a regular a atividade dos inúmeros países nessa matéria. Na busca por sua implementação, seriam indesejáveis quaisquer ações dos Estados no sentido de interferir no curso natural das operações comerciais, como por exemplo, adotando medidas protecionistas, como barreiras alfandegárias, subsídios ou qualquer outra forma de intervenção estatal. A já estudada “mão invisível” do mercado seria a responsável por regular o intercâmbio global.

Não é preciso se afirmar que os cartéis de exportação, por serem formas de estímulo às exportações autuadas por meio da ação do Estado, também seria banidos pela utilização de tal política.

\subsubsection{Reais destinatários}

O terceiro grupo de argumentos a desafiar a utilização dos cartéis de exportação refere-se aos agentes que realmente se beneficiam da utilização desses instrumentos.

Conforme observamos, pretende-se que eles sejam utilizados por empresas que não teriam condições de, sozinhas, colocarem os seus produtos nos mercados internacionais. Como é de se imaginar, essas questões são especialmente relevantes para as pequenas e 
médias empresas, que possuem menor fôlego financeiro para suas atividades do que as grandes empresas. Ocorre que muitos autores entendem que os benefícios da cooperação entre os agentes estariam sendo utilizados apenas por empresas de grande porte, que não precisariam de incentivos para sua atividade comercial.

Da análise dos estudos a que tivemos acesso para este trabalho, não é possível afirmar ser verdadeira ou não a contestação a que ora nos referimos. E isso se dá por dois motivos. O primeiro é a já mencionada escassez de dados numéricos sobre a utilização dos cartéis de exportação. Com efeito, os dados são bastante escassos, não sendo possível formar qualquer convicção com base neles. Nesse sentido, ADITYA BHATTACHARJEA demonstra em estudo que as conclusões obtidas por inúmeros estudiosos são contraditórias, passando pelo entendimento de que os cartéis de exportação seriam utilizados por empresas de grande porte e por aqueles que acreditam que as economias de escala por eles permitidas levariam a uma maior concentração por parte de indústrias com maior porcentagem de capital fixo ${ }^{150}$.

Porque escassos, tais dados não se prestam a uma análise completa dos cartéis de exportação. Esse é o segundo motivo pelo qual entendemos não ser possível tomar qualquer posição sobre a crítica efetuada pela doutrina. Conforme já se afirmou acima, apenas podemos considerar fidedignos os estudos sobre os países que concedem isenções explícitas aos cartéis de exportação e nos quais há necessidade de registro. Em relação aos demais, não há qualquer garantia de que os estudos contemplem a real utilização dos cartéis de exportação.

150 Export cartels, a developing country perspective, cit., p. 11. MARGARET C. LEVENSTEIN e VALERIE Y. SUSLOW realizaram estudo detalhado sobre a utilização dos cartéis de exportação em diversos ordenamentos jurídicos (Op. cit., p. 795). 


\section{OS CARTÉIS DE EXPORTAÇÃO - A POLÊMICA}

\subsection{Motivação da polêmica}

Este Capítulo do estudo se destinará a aprofundarmos a questão da incongruência da utilização dos cartéis de exportação tendo em vista a construção de uma "política internacional da concorrência". Conforme afirmamos no Capítulo 1, temas controversos, como os que agora abordaremos, referentes à relação conflituosa entre os Estados e a adoção de políticas de cunho neoliberal ${ }^{151}$, somente serão trabalhadas na medida em que impactarem a utilização dos cartéis de importação. Como não são o tema deste trabalho, a análise também será realizada de forma superficial.

Já vimos que as teorias clássicas e, especialmente, a busca de teorias estrangeiras por determinados fins para o direito antitruste podem se tornar um óbice aos cartéis de exportação. Logo, uma primeira conclusão a que podemos chegar é a de que sua utilização não depende unicamente de decisões internas dos países, mas está sujeita à pressões externas.

Vamos passar a estudar, então, os motivos que podemos levantar para que tema tão afeto à política comercial seja alvo de ingerência internacional. Acreditamos que além dos discursos teóricos sobre a maior eficiência e variedade de produtos disponíveis aos consumidores mundiais, um outro importante fator contribui para o interesse: a busca pelo acesso aos mercados ${ }^{152}$.

151 As políticas de cunho liberal e neoliberal serão genericamente tratadas como aquelas relativas do Estado Liberal. Em seu viés econômico se caracteriza por "[...] uma concepção estática da vida econômica, toda centrada em torno do equilíbrio natural na produção e circulação de riquezas. A função do Estado é assegurar a existência das condições gerais de manutenção desse equilíbrio e de funcionar eventualmente como um redutor de crises. A própria expressão intervenção na vida econômica trai esta concepção de base de uma harmonia natural das coisas no plano econômico, que deve ser respeitada e garantida" (FABIO KONDER COMPARATO, O indispensável Direito Econômico, Revista dos Tribunais, v. 353, p. 14, mar. 1965).

152 "A doutrina dos chamados países desenvolvidos costuma colocar duas ordens de sugestões para solucionar conflitos de normas e jurisdição antitruste: a progressiva harmonização das legislações, para que se evitassem grandes disparidades entre os sistemas, ou a celebração de tratados visando à colaboração das autoridades antitruste e à diminuição dos problemas políticos decorrentes da extraterritorialidade. Quanto a 
Apesar do esforço para a liberalização do comércio existir há muito na história econômica, nas últimas décadas o estímulo parece ter sido fortalecido. E, acreditamos, isso pode ser em muito justificado pelas alterações ocorridas nos padrões de concorrência internacionais. Com efeito, após a Segunda Grande Guerra, o mundo assistiu a um grupo de países inexpressivos, usualmente denominados Newly Industrialized Countries - NIC, colocar em cheque a hegemonia detida por países como os Estados Unidos e a Inglaterra. Esses países, representados pela Coréia, China e outros de industrialização tardia, conquistaram mercados e obtiveram taxas de crescimento exorbitantes por meio de políticas que não se adequavam à tradicional cartilha liberal.

As alterações no status quo não foram observadas passivamente ${ }^{153}$. Dentro desse quadro, parece fazer sentido a onda de estímulo à aplicação das teorias de livre comércio e da livre concorrência observadas nas décadas de 1970 a 1990. Credita-se aos conselhos, divulgados especialmente por meio das reuniões do Fundo Monetário Internacional- FMI, Banco Internacional de Reconstrução e Desenvolvimento - BIRD e do Tesouro dos Estados Unidos a tentativa de mitigar participação do Estado no estímulo à indústria e ao comércio internacional $^{154}$.

esses tratados, vale destacar que a facilitação do acesso a novos mercados é um dos fatores que impulsiona a busca por uma maior efetividade das leis antitruste e sua aplicação conforme critérios técnicos, procurandose minimizar a influência da política interna de cada país" (PAULA A. FORGIONI, Os fundamentos do Antitruste, cit., p. 518).

153 EROS ROBERTO GRAU retrata as alterações do capitalismo em busca de uma nova ordenação internacional: "De outra parte, o capitalismo, inicialmente 'ordenado' no interesse de cada Estado, vai à busca de uma 'ordenação internacional' - a ordem econômica internacional - que enseja aos Estados desenvolvidos recolher dos subdesenvolvidos as parcelas de mais-valia já não coletáveis internamente de modo intenso" (A ordem econômica na Constituição de 1988, cit., p. 22).

$154 \quad$ “...) desde o surgimento dos NICs (newly industrialized countries), nos anos 1970, que exportavam manufaturados para os países ricos usando sua mão-de-obra barata, a competição dos países em desenvolvimento passou a ser vista como uma ameaça. Como resposta a essa ameaça, buscaram neutralizar a capacidade competitiva dos países em desenvolvimento através do que denomino de 'ortodoxia convencional' - ou seja, oferecendo a essas países uma serie de diagnósticos, conselhos e pressões. O principal deles, depois que o uso ideológico da lei das vantagens comparativos perdeu seu poder persuasivo, tem sido a proposta de crescimento com poupança externa, que aprecia as taxas de cambio dos países que a aceitam e os desorganiza financeiramente. Mais amplamente, os países ricos transformaram um fenômeno real que é a globalização em uma ideologia contrária à idéia de Nação nos países em desenvolvimento: o 'globalismo' - uma ideologia à qual as elites dos países de desenvolvimento nacional-dependente (não as de desenvolvimento autônomo) se submeteram. Segundo essa ideologia, a globalização implica aumento da interdependência entre os Estados-nação; eles perdem autonomia para fazer políticas econômicas, e assim a própria idéia de Nação perde relevância: agora viveríamos em um mundo sem fronteiras no qual as empresas multinacionais são o principal agente de racionalidade e crescimento" (LUIZ CARLOS BRESSERPEREIRA, Desenvolvimento Econômico e Revolução Capitalista, cit., p. 15). 
Ainda nesse contexto de contenção da "subversão" na ordem internacional, é interessante observar o surgimento e o espraiamento de um novo termo, muito útil às idéias que se pretendiam fomentar. Trata-se do conceito de "globalização" 155 . MANOEL JORGE E SILVA NETO assim o relaciona com os ideais neoliberais da década de 1980/1990 e o famoso consenso de Washington ${ }^{156}$ : “A globalização, entendida como 'termo que designa o fim das economias nacionais e a integração cada vez maior dos mercados, dos meios de comunicação e dos transportes, recebeu forte impulso a partir de reuniões realizadas no início dos anos 90 entre representantes do FMI (Fundo Monetário Internacional), BIRD (Banco Internacional de Reconstrução e Desenvolvimento) e do Tesouro dos Estados Unidos, dando origem ao que se passou a denominar de "Consenso de Washington" receituário econômico dirigido de modo mais marcante aos países em desenvolvimento, que, em suma, prega a abertura das economias nacionais e a gradativa retirada do Estado de inúmeras atividades reputadas de exclusiva competência dos entres privados, tudo para viabilizar o ajuste fiscal"157-158.

155 Assim definido, em seu aspecto econômico, por ANA MARIA NUSDEO: “A expressão 'globalização econômica' refere-se à crescente interligação dos mercados nacionais por meio do aumento da circulação entre eles de bens, serviços e capitais, induzida pela redução de tarifas e de barreiras não tarifárias sobre esses fluxos e, ainda, por alterações tecnológicas que permitem a instantânea transmissão de dados e informações entre os mercados distantes. Tal processo e as possibilidades dele decorrentes têm provocado efeitos como a alteração da estratégia competitiva das empresas, a dispersão internacional das etapas do processo produtivo, a homogeneização de hábitos de consumo e de práticas comerciais, a desregulamentação dos mercados financeiros e de outros setores das economias nacionais e, ainda a formação de blocos regionais de livre comércio" (Op. cit., p. 138).

156 O consenso de Washington é um conjunto de medida, cunhadas em 1989 por instituições como o Fundo Monetário Internacional e o Banco Mundial com medidas de caráter de política econômica a serem seguidas pelos países. Seus principais preceitos são: i) garantia do direito de propriedade; ii) privatizações; iii) liberalização comercial; iv) liberalização dos financiamentos; v) ajustes nos gastos públicos; vi) disciplina fiscal; vii) reforma fiscal; viii) unificação nas taxas de câmbio; ix) extinção das barreiras ao investimento externo; e x) desregulamentação.

157 MANOEL JORGE E SILVA NETO, op. cit., p. 90.

158 Com relação ao tema, a contundente crítica de HA-JOON CHANG: "Em relação aos países em desenvolvimento, a agenda neoliberal foi potencializada por uma aliança entre os governos dos países ricos liderados pelos Estados Unidos e mediada pela trindade 'profana' das organizações econômicas internacionais que eles controlam firmemente - o Fundo Monetário Internacional (FMI), o Banco Mundial e a Organização Mundial do Comércio (OMC). Os governos ricos usam os orçamentos e o acesso a seus mercados de origem acenando como cenouras para induzir os países em desenvolvimento a adotarem as políticas neoliberais. Tentam criar um ambiente no país em desenvolvimento favorável aos bens e investimentos estrangeiros em geral. O FMI e o Banco Mundial fazem sua parte ao atrelarem aos empréstimos a condição de que os países devedores adotem a política neoliberal. A OMC contribui ao estabelecer regras de comércio que favorecem o livre mercado em áreas nas quais os países ricos são mais fortes, mas não onde eles são mais fracos (por exemplo, na agricultura ou na industrial têxtil). Esses governos 
Não nos restam dúvidas de que o desenvolvimento tecnológico das últimas décadas foi responsável pela diminuição das distâncias físicas entre os países. Especialmente no campo das comunicações, os avanços foram tamanhos que hoje é comum a comunicação em tempo real com países localizados do outro lado do globo, coisa que seria impensável há alguns anos. As benesses desse desenvolvimento são indiscutíveis, permitindo a maior interação entre as pessoas e o intercâmbio cultural, tecnológico e social.

No âmbito comercial e industrial, a facilidade de comunicação e de transporte trouxe alterações significativas, permitindo a existência de grandes conglomerados internacionais, com filiais e funcionários distribuídos pelo mais diversos países. Essas estruturas substituíram as antigas empresas fixadas em um único território e permitiram tamanha mobilidade nas linhas de produção que, não raramente, cada um dos itens que compõe determinado produto é produzido em áreas diversas do globo. A escolha do local de fabricação é feita tendo em vista questões financeiras, como os custos de produção e de logística.

O conceito de globalização é útil à busca pelo livre comércio e livre concorrência na medida em que se associa a facilidade de interação entre os agentes à diminuição das barreiras econômicas entre os países, ao aumento do intercâmbio de produtos, serviços e tecnologias e à maior liberdade na forma como isso é feito.

Ademais, em discussões mais amplas, não é raro encontrar questionamentos ao próprio conceito de soberania Estatal. Nas palavras de ANA MARIA NUSDEO: "Nesse campo a discussão mais importante refere-se ao enfraquecimento do conceito de soberania do Estado. Formulado inicialmente para a formação do poder absoluto do soberano dentro dos limites territoriais dos Estados-Nações, quando estes se encontravam em formação, o conceito de soberania vem sendo gradualmente desenvolvido no sentido da limitação desse poder e na construção de mecanismos para sua legitimação, o que inclui a sua divisão entre três instituições independentes e com funções complementares, a separação da esfera política e econômica, a autonomia do Direito e o monismo jurídico, em termos formais,

e organizações internacionais são apoiados por um exército de ideólogos. Algumas dessas pessoas são acadêmicos altamente especializados e deveriam conhecer os limites de sua economia de livre mercado, mas tendem a ignorá-los quando dão recomendações de política econômica (assim como aconteceu quando eles orientaram as ex-economias comunistas nos anos 90)" (Maus Samaritanos, O mito do livre comércio e a história secreta do capitalismo, Rio de Janeiro, Elsevier, 2009, p. 13). 
assim como as garantias aos direitos individuais e aos direitos humanos, em termos materiais". 159

O cenário que está sendo cuidadosamente desenhado, de integração entre países e de livre intercâmbio de produtos e capitais, parece ser bastante a justificar a existência de legislações concorrenciais elaboradas e interpretadas dentro dos mesmos padrões. Mais do que isso, poderia dar ensejo à adoção de uma "política internacional da concorrência". A afirmação de AJIT SINGH justifica esse entendimento: "Competition policy has emerged as a major issue on the global trade agenda due to the pressure by major developed countries who consider that the increasing liberalized world economy the issue of competition should be addressed at the international level and appropriate agreements and

159 E continua: "Com efeito, a tendência à formação de ordens jurídicas, ainda que fragmentárias, espontâneas e desvinculadas do poder e da justiça estatal erode o pressuposto no monismo jurídico, essencial ao Direito moderno. Por outro lado, à medida que parte dos governados - justamente aqueles que têm maior influência na economia - passam a atuar de forma independente dos limites territoriais e, principalmente, se deslocam com muita facilidade pelas fronteiras nacionais, a capacidade regulatória do Estado-Nação se vê enfraquecida. A função deste último de controle das crises do sistema capitalista e das suas tendências autodestrutivas torna-se cada vez mais difícil e complexa, exigindo com freqüência o apoio de instituições internacionais, como o Fundo Monetário Internacional (FMI). Sua prerrogativa de implementação de política econômica, por sua vez, também é limitada e pautada pela preocupação em atrair capitais, produtivos ou não. Isso impõe aos Estados a escolha de determinados tipos de instrumento de política econômica, em detrimento de outros. Nesse sentido, por exemplo, são implementadas com freqüência políticas de estabilização fiscal e monetária, de abertura comercial e de privatizações, mas são raras as políticas voltadas, por exemplo, para garantir o pleno emprego. Esse processo, como é evidente, não implica o desaparecimento do Estado-Nação, nem de sua estrutura administrativa, mas, simplesmente, enfraquece suas prerrogativas de soberanamente comandar e dirigir políticas públicas autônomas, independentes de fatores externos e do fluxo de capitais internacionais. Uma redefinição das funções e dos instrumentos de políticas públicas disponíveis do Estado nacional é tarefa a ser desenvolvida pelas Ciências Econômicas, e Sociais e pela Teoria do Direito, tendo em vista a paradoxal independência do mercado à regulação estatal e, ao mesmo tempo, sua dependência de políticas industriais e econômicas que lhe favoreçam a concorrência no novo cenário, sobretudo se o processo de globalização econômica seguir a intensidade atual. Com efeito, e como já foi observado, o Estado, ainda quando enfraquecido, terá de organizar as reações nacionais ao movimento de globalização, seja através de respostas protecionistas, seja formulando políticas de sua economia nesse contexto, criando-lhe vantagens comparativas e condições de atratividade para o capital externo. [...]. Em contraposição, porém, é levantado que a globalização exige a adaptabilidade dos agentes econômicos a um ambiente mais competitivo e internacionalizado, o que pode ser estimulado por uma política antitruste efetiva nos seus mercados nacionais de origem. Por outro lado, o processo de globalização representa uma tendência possível de afetar a concorrência, mas que pode coexistir com processos de produção, comercialização e disputas por mercados em níveis nacionais, regionais e locais, onde seu impacto é reduzido. Essa realidade leva ao descrédito o argumento de que políticas comerciais liberais podem substituir uma política antitruste. Nesse sentido, a globalização, antes que eliminar a soberania do Estado para implementar políticas econômicas, exige a adaptação destas a um contexto diferente de organização da produção, de disponibilidade de créditos e de circulação de investimentos, assim como de concorrência. Por isso, o direito da concorrência não pode ser apontado como vítima do enfraquecimento da soberania do Estado, condenado à ineficácia. Antes, a globalização econômica tem de ser entendida como o contexto fático da economia sobre o qual as políticas antitruste devem se desenvolver, já que, como é obvio, nenhuma legislação que se pretenda regular a esfera econômica prescinde da compreensão de seu funcionamento e condicionantes econômicos e sociais" (Op. cit., p. 153 e ss.). 
rules be negotiated ${ }^{160 "}$. A unificação seria justificável na medida em que as legislações nacionais não seria capazes de lidar com a nova realidade trazida pela globalização e pelas operações que transbordam os limites territoriais dos países ${ }^{161}$.

Nessa onde de incentivos, assistimos ao longo da década de 1990 o surgimento de inúmeras legislações antitruste com clara inspiração nas normas norte-americanas e a adoção de políticas market friendly, ou seja, voltadas para livre comércio ${ }^{162}$. A influência dos ideais clássicos e da Escola de Chicago chegou ao ponto de o termo "eficiência", característico da última, passar a ser empregado como sinônimo de matéria concorrencial.

Como é de se imaginar, a discussão ora relatada é cercada de conflitos, interpretações ideológicas e exageros, quer por parte dos teóricos liberais, quer por parte de seus oposicionistas. Assim, ainda que desconsideremos as motivações que podem ter levado à exacerbação na busca pelo livre comércio e pela não intervenção do Estado na economia, não podemos deixar de notar o eco que essas idéias encontram pelo globo. Em termos mais concretos, podemos encontrar efetivos projetos para a criação de legislações concorrenciais comuns. A função dessas normas, segundo BRENDAN J. SWEENEY seria a de sobrepujar eventuais incompetências das leis concorrências nacionais e problemas relacionados ao protecionismo das leis nacionais ${ }^{163 "}$.

160 E continua afirmando que, na verdade, a discussão é antiga, datando dos idos de 1960, quando se tratava da existência de um código que coibisse a ação das grandes transnacionais e que atuasse sobre as condutas tidas como anticompetitivas, mas esses objetivos foram esquecidos, trazendo-se para o seu lugar interesses que somente interessam aos países do Norte, ou seja, os desenvolvidos (AJIT SINGH, op. cit.).

161 "Domestic regulation, however, does not always operate effectively where the relevant conduct is transnational. First, transnational conduct creates incentives for protectionism which domestic regulation is not always able to handle. Protectionism is an international problem where it undermines international trade commitments. Secondly, transnational conduct exposes the problem of concurrent jurisdiction". BRENDAN J. SWEENEY, cit., p. 213).

162 BRENDAN J. SWEENEY relata que nos anos 80 existiam apenas 20 países com leis concorrenciais. Esse número subiu para 98 no ano de 2000 (Op. cit., p. 210). AJIT SINGH nos revela outra perspectiva sobre o surgimento de novas leis concorrenciais - para ele, elas surgiram em decorrência da onda de fusões e aquisições que caracterizou a década de 1990: "Whether the mergers take place um the US or Europe or through cross border takeovers in developing countries themselves, there are serious competition policy concerns for developing countries. IF the largest producers in, say the US automobile industry merge, this may not only lead to anti-competitive behavior in the US but also similar or worse behavior in developing countries (e.g. cartelization of markets, increased barriers to entry). The US has long had a competition policy which provides it with a defense against such welfare-reducing consequence of mergers" (Op. cit., p. $5)$.

163 "It is in these areas, where domestic regulation fails, that international rules are needed the most. Given the objections to uniformity and the difficulties in negotiating international rules, some limiting or constraining principle is required. It is suggested that the shape of a CGA (General Competition Agreement) 
ANA MARIA NUSDEO se refere à um deles, estabelecido na cidade de Munique, no ano de 1993 e que prevê, inclusive, a existência de uma autoridade concorrencial - a International Antitrust Authority - responsável por zelar pela aplicação do direito em comento $^{164}$. BRENDAN J. SWEENEY, por seu turno, afirma que a tentativa mais importante de criar-se uma política da concorrência global ocorreu em 1996, com a inclusão do tópico na agenda da Organização Mundial do Comércio - OMC ${ }^{165-166}$.

should be determined by the minimum requirements necessary to overcome the international problems exposed by domestic regulatory failure. In others words, the shape of a GCA will be informed by what is necessary to overcome protectionism and problems such as the de facto international regulator. Op. cit., p. 213.

164 “Com a criação da Organização Mundial do Comércio - OMC - e eliminação de várias barreiras tarifárias e governamentais, a necessidade de criação de regras antitruste destinadas à remoção de barreiras privadas ao livre comércio internacional tem sido crescentemente defendida. Já existem propostas concretas de regras multilaterais a serem incorporadas num possível tratado a respeito. A principal dessas propostas foi elaborada por um grupo de especialistas representando diferentes países, predominantemente europeus, reunidos em Munique em 1993, a visa à adoção de um 'Código' contendo regras substantivas mínimas a serem incorporadas pelos ordenamentos dos países aderentes bem como a obrigatoriedade de criação de procedimentos e de constituição de autoridades independentes para sua aplicação no âmbito interno. A par disso, no âmbito internacional, o Código cria uma autoridade executiva (International Antitrust Authority), composta por 1 presidente e 20 conselheiros, com competência para requerer às autoridades nacionais que investiguem determinados casos e, na falta de cumprimento da requisição, para iniciar procedimentos perante as Cortes nacionais. Entendendo ter havido violação ao Código por um dos Estados, pode levá-lo ao Painel Internacional, órgão com poderes quase-judiciais, formado por um corpo permanente de árbitros, com mandato de seis anos - diferindo assim, dos painéis do GATT, formados por membros ad hoc. Sua proposta é, assim, conciliar as leis antitruste nacionais com uma esfera internacional tendente a forçar os Estadosmembros a manter a eficácia das normas. Trata-se de regras subsidiárias às normas antitruste nacionais, inspirando-se, portanto, no mecanismo normal do ordenamento da Comunidade Européia, no qual as questões são primeiramente apreciadas em esfera local ou nacional, sendo submetida aos órgãos comunitários posteriormente - salvo em determinadas matérias, como o direito da concorrência, em que a competência dos órgãos comunitários é originária para questões que afetem o comércio dentro do mercado comum" (Op. cit., p. 168-169).

165

Op. cit., p. 211.

166 ELEONOR M. FOX faz referência a diversos tipos de acordo que, como já afirmamos na nota 3, serão tratados genericamente de "política internacional da concorrência": "There are four basic approaches to thinking about competition law and the world trading regime. One envisions a nearly complete international code with supranational enforcement agency. This is the approach taken by the Munich group, whose proposed International Antitrust Code was released in the fall of 1993 as a draft GATT plurilateral agreement. A second approach entails no international law as such but harmonization of national antitrust laws. This option envisions either 'loose' harmonization - roots-up convergence through such crossfertilization - or tight harmonization - persistent coaxing of nationals laws into identity, or near identity. The project could involve a 'uniform laws' project, much like uniform laws enterprises in the United States such as the U.S. Uniform Commercial Code. Drafted by experts, the code contains many rules and some options. Virtually every U.S. state has adopted it voluntarily, in one form or another. Under the third approach by the group of experts convened by European Competition Commissioner van Miert and reflected in the more generalized proposal for a explanatory working group by the European Commission, nations would first develop and refine bilateral agreement that strengthen cooperation between competition authorities, including through positive comity. [...]. An interaction of the third approach, one that could supply content to the concept of 'appropriate competition rules', is a proposal for linking principles of a constitutional dimension. Principles of constitutional generality could prohibit anticompetitive blockages of market access and transational cartels, and provide a discipline for unjustified trade-restraining acts of states. Nations would be 
Assim, a despeito de qualquer discussão ideológica ente os países centrais e os periféricos, parecer ser incontroverso que a adoção de padrões comuns na lei concorrencial (ou, como estamos aqui chamando, de uma "política internacional da concorrência"), terá o condão de afetar a forma pela qual as normas antitruste internas são hoje trabalhadas e, nessa medida, afetar os cartéis de exportação. É função desse Capítulo examinar quais seriam os possíveis benefícios e problemas que seriam encontrados para a adoção de tais padrões comuns.

\subsection{Benefícios da política comum}

Não é de se negar que a harmonização das legislações concorrenciais (e sua forma de interpretação) traria maior fluidez para as relações comerciais internacionais. Uma das razões para isso seria a redução dos custos de transação (já estudados no Capítulo 3): o comportamento dos agentes, ainda que estrangeiros, poderia ser mais bem compreendido e identificado, o que aumentaria o grau de segurança de previsibilidade dessas relações. Uma unificação de padrões permitira que, de antemão, se soubesse o enquadramento legal que seria dado, por exemplo, às restrições verticais, o que permitira maior convicção para os agentes econômicos no momento de formular suas estratégias de atuação no mercado (ou seja, sabe-se, com antecedência, que a conduta A é permitida e interpretada de tal maneira em todos os ordenamentos).

De modo sintético, os benefícios de uma política antitruste global poderiam ser traduzidos: i) pela unificação dos padrões e comportamento dos agentes; ii) pela inexistência de excludentes para práticas entendidas como anticoncorrenciais; e iii) pela busca da proteção ao consumidor globalmente considerado ${ }^{167}$.

required to prohibit the few consensus wrongs at their source. A fourth approach derives from an overriding skepticism about the multinational bargain table. It begins with the strong presumption that all that needs to be done can be done at the national level through national law or enforcement agency cooperation, and that some issues can be dealt with through sectoral trade agreements. This position seems to be reflected in statements by certain U.S. antitrust enforcement authorities" (World antitrust and market Access, In The American Journal of International Law, v. 91, n. 1, jan., 1997, p. 2).

167 "There are a variety of reasons for championing a GCA (Global Competition Agreement). Some view a GCA especially one linked to he WTO, as a useful way of imposing economic reforms on reluctant states. A GCA may also be viewed as a way of overcoming the sub-optimality of domestic regulation; as long as states consider only their national interests (their own consumers and producers), domestic regulation will produce a welfare deficit when compared to that which might be obtained under global regulation. 
O primeiro benefício fundamenta-se na idéia de que as autoridades podem sinalizar para a sociedade o comportamento que esperam dos agentes em suas relações. Essa é a mesma lógica encontrada quando o Código Penal brasileiro dispõe em seu artigo 121: "Matar alguém - Pena - reclusão, de 6 (seis) meses a 20 (vinte) anos". O texto tem o condão de estabelecer para a sociedade que aquela prática é vedada no ordenamento jurídico e não deve ser realizada, sob pena de determinada sanção. Com a proibição, espera-se que muitos homicídios sejam evitados, uma vez que os agentes conhecem (ou deveriam conhecer) qual é o padrão de comportamento traçado para aquela sociedade. Para que o desestímulo seja eficaz, não é raro que a norma imponha sanções aos seus infratores. Obviamente, há aqueles que não seguem o padrão e, por isso, recebem as penalidades cominadas.

O resultado da existência da lei é criar um senso de normalidade e expectativa sobre o comportamento que será observado pelos agentes. Nesse sentido, podemos mais uma vez falar em um certo grau de segurança e previsibilidade, que pode ser um fator de redução dos custos de transação.

Uma norma internacional antitruste teria a função de parametrizar padrões legislativos e de interpretação das normas concorrenciais espalhadas pelo globo. Isso porque, a despeito de elas convergirem em muitos aspectos, a interpretação a elas conferida, ao longo do tempo, tem sido bastante divergente. Não é raro que encontremos situações nas quais, a despeito de determinada conduta ser cominada, outros fatores sejam utilizados para temperar a proibição, o que resulta em sua flexibilização. O caso dos cartéis de exportação, por exemplo, é bastante emblemático. Observaremos no Capítulo 4 que eles podem ser entendidos como atos de concentração entre agentes econômicos que podem prejudicar a concorrência, nos termos do artigo 54 da lei antitruste brasileira. Por outro lado, podemos vislumbrar que eles podem trazer eficiências, que justificariam a concentração nos termos do mesmo artigo. A existência de uma norma internacional proibindo os cartéis de exportação acabaria com tal possibilidade. ADITYA BHATTACHARJEA, nos explica a vantagem: "The first pillar of the MAC argument is the need to harmonize different national competition laws so that firms do not have to comply with different standards in the different countries in which they operate, and to

Finally, a GCA may be seen as a way of avoid the tensions that the extraterritorial application of domestic competition laws often generates" (BRENDAN J. SWEENEY, op. cit., p. 212). 
deal with contradictory rulings from different national authorities. Apart from different legal conditions in different countries, there is very little consensus on the substantive issues of competition policy" 168 .

A busca por esse padrão único de comportamento está intimamente ligada ao segundo benefício relacionado com à criação da "política internacional da concorrência", que é o de impedir que um ato ocorra sob a justificativa de que ele também é praticado por outros agentes. O argumento pode soar infantil, mas a inexistência de leis globais impedindo atos anticompetitivos é uma das razões levantadas pelos Estados para justificar a sua prática ou para que eles não sejam coibidos. Em termos populares, poderíamos aplicar a lógica do "se ele pode, eu também posso""169.

Com efeito, se não existe determinação legal para que os Estados procedam de uma ou outra forma, não há que se esperar (e muito menos exigir) que espontaneamente adotem políticas mais "simpáticas" ao livre comércio internacional. Isso é ainda mais verdadeiro quando verificamos o benefício econômico advindo desses atos. Nas palavras de SPENCER WEBER WALLER, ao tratar especificamente do tema deste estudo ${ }^{170}$ : "the absence of international regulation pertaining to the use of export cartels leaves a conspicuous gap in the enforcement of competition norms". No mesmo sentido se manifestam algumas associações americanas voltadas à atividade de exportação: "Specifically, several countries, including but not limited to Canada, Mexico, Australia, India, South Africa, Israel and Taiwan, have explicit exemptions for export trade similar to the U.S. exemption. And the antitrust law of virtually every other jurisdiction - including (for example the European Community by virtue of Article 85 (1) of the Treaty of Rome) -

168 Trade and Competition Policy, Indian council for research on international economic relations, cit., p. 7.

169 "Experience has shown that the legal authorization of export cartels by one country may be an incentive for other countries to Grant similar exemptions. For example, when the Webb-Pomerene Act was introduced, a House Judiciary Committee report stated: 'European nations permit organizations or combinations with respect to their foreign trade... In Germany alone prior to the beginning of the European war there were 600 important cartels... and many devoted themselves largely to export trade... Our merchants and manufacturers must meet this situation" (OECD, op. cit., p. 51).

170 Citado por MARGARET C. LEVENSTEIN e VALERIE Y. SUSLOW, op. cit., p. 786. No mesmo sentido: "As long as there is no coherent legal regime of international competition law, there is an asymmetry of deciding-making powers. Domestic decisions in two different policy fields influence the outcome (the state of free trade in global economy), but one of those areas (trade policy) is embedded in an international decision-making structure, and the other (competition policy) largely remains a national domain. This asymmetry is the breeding ground for a remarkable leniency towards restriction of competition having effects on a market outside the regulating state" (FLORIAN BECKER, op. cit., p. 100). 
explicitly address and restrict only activities restricting competition within their respective borders, thereby also implicitly approving of joint export associations" ${ }^{171}$.

Uma das formas encontradas para que os Estados "permitam" a ocorrência no exterior de práticas que, a princípio, não seriam admitidas no ordenamento interno é a modulação da aplicação do direito. Vamos observar no Capítulo 8 que elas podem ser empregadas unicamente para a disciplina dos atos que afetam o mercado interno de determinado país, nada dispondo sobre aqueles que ocorrem fora de seu território. Em via reversa, elas deixam o "caminho livre" para que práticas anticompetitivas tenham lugar nesses ambientes.

Um terceiro benefício aclamado para a adoção de uma "política internacional da concorrência" refere-se à proteção do consumidor. Conforme se verificou no Capítulo 2, a proteção ao consumidor foi estabelecida como um dos objetivos da disciplina antitruste. Ocorre que, usualmente, o consumidor que recebe o abrigo é aquele nacional, protegido pelos limites geográficos de cada país.

Uma das grandes bandeiras defendidas por aqueles que pregam a uniformização das regras concorrenciais é que, na medida em que as barreiras entre países não mais se justificam (pela globalização), seria ilógico que a proteção ao consumidor se restringisse no espaço. A proteção deveria ser concedida a todos, independentemente de onde se encontram. ELEONOR M. FOX resume o problema: “(...) given the importance of states' rights to act in the public interests of their citizens, what are the limits o state action that obstructs free trade and competition and thereby harms the interests of the larger community? ${ }^{172, " . ~ E m ~ u m ~ e x e m p l o, ~ d e v e r i ́ a m o s ~ e s p e r a r ~ q u e ~ a ~ F e d e r a l ~ T r a d e ~ C o m m i s s i o n, ~}$ ao tomar qualquer decisão em um ato de concentração, deveria examinar seus efeitos tendo em vista não apenas os consumidores americanos, mas também aqueles que se encontram fora desse país. A adoção da "lei antitruste internacional" seria a forma para se implementar o alargamento da proteção.

171 Correspondência encaminhada por associações de exportadores à Antitrust Modernization Commission, no dia 7 de janeiro de 2005. No mesmo sentido, o discurso do Parlamento israelense: "If others economies, much more developed than our own and with longer experience with competition law, have chosen to exempt their agricultural sector from the rules on restrictive agreements - why shouldn't we do the same?” (ARIE REICH, op. cit., p. 845).

172 ELEONOR M. FOX, op. cit., p. 2. 
A confirmar esse posicionamento, que em teoria pode ser considerado bastante simpático, colacionamos o entendimento de CÉSAR MATTOS, ao tratar do tema "bemestar do consumidor e a aplicação da lei antitruste", afirmando ser necessário que cada país, ao aplicar o direito, leve em consideração não só o bem-estar dos consumidores internos, mas também o bem-estar dos consumidores estrangeiros ${ }^{173}$. Por conseqüência, os cartéis de exportação não deveriam ser aceitos na ordem internacional, porquanto seriam fontes de prejuízo aos consumidores, que não aproveitariam os benefícios do livre mercado. No mesmo sentido, MARGARET C. LEVENSTEIN e VALERIE Y. SUSLOW: "If we have a general consensus that price fixing harms consumers, then export exemptions benefit a nation only to the extent that they harm foreign consumers. The policy is one of enriching oneself at the expense of one's trading partners. A multilateral agreement to eliminate these exemptions and price fixing the same wherever it occurs, or in whatever market is targeted, would improve global consumer welfare" ${ }^{, 174}$.

\subsection{Dificuldades de uma política comum}

Tendo sido verificados os possíveis benefícios da adoção de uma política internacional conjunta, é hora de nos determos nas dificuldades que seriam encontradas

173 Harmonização das políticas de defesa da concorrência e comercial: questões teóricas e implicações para o Mercosul, ALCA e OMC, In Est. Econ., São Paulo, v. 29, n. 2, abr.-jun. 1999, p. 283.

174 Op. cit., p. 813. No mesmo sentido, as assertivas de A. PAUL VICTOR: "Essentially these laws authorize firms to collaborate to engage in anticompetitive behavior in foreign markets, at the expense of other countries' consumers and producers, in a manner that would be unlawful if undertaken at home" (Op. cit.); e de FLORIAN BECKER: "[...] in allowing otherwise prohibited conduct because only foreign markets are target, states assist in affecting the target market in a way that is prone to hurt its consumers and producers just as much as by barring its economy from exporting” (Op. cit., p. 99). Ainda, as considerações feitas por DANIEL SOKOL: "This explanation for the origin and continuation of export cartels rest upon a public choice theory. Regulation (including immunities from said regulation) is a function of successful rent seeking by small and well organizes interest groups. Specific to export cartels, those consumers that are most affected by export cartels are foreign consumers. Foreign consumers are a large and diffuse group, which makes such group less effective than participants of export cartels to mobilize politically to protect their interests at the expense of total welfare" (Op. cit., p. 3) e a de RICARDO MEDEIROS DA CUNHA: "[...] não devemos nos esquecer que muitos países se utilizam de mecanismos jurídicos que toleram condutas anticompetitivas contrárias aos consumidores estrangeiros, dentre eles, os brasileiros. Os Estados Unidos, por exemplo, possuem instrumentos (como o Webb-Pomerene Act, de 1918, e o Export Trading Company Act) que conferem imunidade em relação ao Sherman Act e ao Clayton Act, permitindo, explicitamente, que empresas norte-americanas formem cartéis de exportação. Outros países como Austrália, Canadá, Israel, África do Sul, Taiwan, Japão e Alemanha possuem ou já possuíram instrumentos jurídicos análogos. Tal estado de coisas demonstra como as autoridades devem estar atentas a essas políticas externas deletérias que - de forma deliberada - consciente e com chancelas governamentais estrangeiras - se apropriam do bemestar social de outros países" (Antitruste e Comércio Internacional, CADE Informa, disponível em http://www.cade.gov.br/news/n021, acesso em 15 out. 2009). 
para a implementação do projeto. Escolhemos analisar os seguintes pontos de conflito: i) consenso sobre o texto a ser aprovado; ii) comportamento dos Estados; e iii) controle e aplicação do direito.

\subsubsection{Do texto a ser aprovado}

Diversidades culturais, políticas, lingüísticas, religiosas, econômicas e geográficas, tornam cada país único. Especialmente com relação aos aspectos econômicos, a desigualdade parece ser a palavra de ordem: enquanto de um lado do globo a riqueza é pujante e o desenvolvimento a ordem do dia, de outro, as perspectivas são bastante insatisfatórias e a fome ainda faz muitas vítimas. Essas características estruturais, aliadas à séculos de exploração, acabaram por cindir o mundo entre países desenvolvidos e aqueles países ditos subdesenvolvidos.

As diferenças ocorrem mesmo entre os países que integram os mesmos "subgrupos" econômicos. Sob a mesma alcunha de "países em desenvolvimento" estão

países tão díspares quanto Brasil, Índia e África do Sul. Isso para não citar as desproporções existentes entre os países considerados pobres (como comparar o Zimbábue e o Laos?). É dentro desse caldeirão fervilhante que se discute a adoção da "política internacional da concorrência".

É de se imaginar a dificuldade que seria encontrada para a elaboração de um texto único, que atendesse aos anseios e à realidade econômica e social de países tão díspares. Em dois simples exemplos, podemos verificar o tormento que significa a busca de um documento comum: o Pacto de San José da Costa Rica, de 1969, que trata de matéria relativa aos direitos humanos (e, nessa medida, acreditamos, menos polêmica do que as relativas a temas econômicos) não foi até hoje ratificado pelos Estados Unidos. No Brasil, a ratificação ocorreu apenas em 1992. No campo concorrencial, podemos citar a padronização do tratamento conferido aos cartéis clássicos, até os dias de hoje não pacificada (a tentativa, de 1988, resultou apenas em uma série de recomendações não vinculantes visando ao seu banimento). Como bem afirma ERIK JOHANSEN, as 
inconsistências teriam início ao tentar definir o que seria competição para cada um desses países $^{175}$.

Ainda que se cheguem a termos comum, há mais uma etapa a ser vencida, que á a da interpretação. A esse respeito, DANIEL GOLDBERG relata-nos o julgamento do ato de concentração entre a GE e a Honeywell, que enfrentou análises substancialmente diferentes do Departamento de Justiça americano e da Comissão Européia. As duas autoridades antitruste concordaram com o fato de que existia grande complementaridade entre os produtos oferecidos pelas requerentes, o que poderia levar a preços substancialmente mais baixos para a produção dos bens que seriam colocados no mercado. $\mathrm{O}$ entendimento da autoridade americana, bastante em linha com os ensinamentos da Escola de Chicago, foi o de que as economias de escopo e as eficiências advindas da fusão seriam pró-competitivas, levando a uma melhor alocação dos recursos no mercado. A autoridade européia, por outro lado, apresentou entendimento completamente diverso, argumentando no sentido de que a criação de uma empresa com tais proporções poderia afetar inadequadamente o setor no qual as empresas atuavam, prejudicando a dinâmica concorrencial existente, o que poderia constituir uma ameaça ao livre mercado. Outros casos em que as visões antagônicas ficaram evidentes foram a da fusão entre a Boeing e MacDonnel Douglas e entre CibaGeigy e Sandoz ${ }^{176}$.

Dentro desse quadro, percebe-se que, mesmo entre países desenvolvidos, como os Estados Unidos e a União Européia, existem diferenças muito grandes, não só no texto de suas normas concorrenciais, mas também na forma como empregam e interpretam dita legislação (a esse respeito, consultar o Capítulo 6) ${ }^{177}$.

175 E continua ao afirmar que no campo do comércio internacional entender a aplicação das leis antitruste pode se tornar complicado na medida em que se analisam as nuances dos objetivos dos governos em particular. Com relação à distinção entre a política americana e a da Comunidade Européia, explica: "Over the past decades, U.S. antitrust law has been dominated by the economics-based, Chicago-school approach to antitrust policy, which relies heavily on allocative efficiency models and price theory. EU competition law, on the other hand, is less concerned with the 'Kaldor-Hicks, potential Pareto sense of efficiency' than with factors such as barriers to entry, market integration, fairness and direct consumer welfare" (ERIK JOHANSEN, I say antitrust; you say anticompetitive: why bridging the devise between U.S. and EU competition policy makes economic sense, In 24 Penn St. Int'l L. Rev. 331, 2005-2006, p. 332).

176 ADITYA BHATTACHARJEA, Trade and Competition Policy, Indian council for research on international economic relations, cit., p. 7.

$177 \quad$ Nesse sentido: "The major obstacle to a GCA on export cartels is the lack IF consensus about their competitive significance. But it is not the only obstacle. How would an export cartel rule be structured? Different states deal with export cartels in different ways. In some states, for example, the EU and most its 
Essa dificuldade em se chegar a denominadores comuns já foi vislumbrado quando dos estudos para a constituição do Código de Munique, acima citado. Uma das formas encontradas para pacificar os ânimos e dar seguimento aos trabalhos foi a adoção de "termos vagos", que, por conterem maior maleabilidade no tratamento das questões concorrenciais, seriam mais facilmente aceitos pelos países ${ }^{178}$. Como se observará no Capítulo 8, é usual que os textos antitruste se valham de tais termos fluídos, por permitirem melhor adequação da legislação ao caso concreto e a sua instrumentalização para a adoção de políticas públicas. A utilização desse tipo de linguagem em um documento internacional, entretanto, pode ser questionável. Se cada intérprete puder analisar o texto de forma diversa, há grande possibilidade de desentendimento entre os Estados sobre a correta forma de interpretação e aplicação da "política internacional da concorrência", podendo gerar conturbação nas relações entre países.

Há ainda uma outra importante questão: por tudo o quanto se analisou até agora, podemos supor que existirá considerável pressão para que, se adotada, a "política internacional da concorrência" siga princípios ligados à Economia Neoclássica e, consequentemente, adequados ao livre comércio e à livre concorrência. Nesse ponto, é de

Member states - export cartels are generally not unlawful because they have no local, anti-competitive effects. There is no need for any special exemption. In other states, where hard core cartels are prohibited per se (that is, without any competitive effect test) exemptions are available for export cartels that have no, or no appreciable adverse local effects. This is the case, for example, with the US, Australia and India. The different approaches rule out any simple solution. An agreement not to exempt export cartels from local law or not to discriminates between local and export cartels would have no effect in those states where cartels are judged under a competitive effects test” (BRENDAN J. SWEENEY, op. cit., p. 225).

\footnotetext{
178 "Não há prognósticos, porém, da entrada em vigor de tal Código. Como é previsível, o texto tem sido objeto de diversas críticas. As mais relevantes apontam a dificuldade de conciliar os diferentes conceitos típicos das legislações nacionais, o que levou à adoção de termos excessivamente vagos e ambíguos. Conforme aponta Daniel Gifford: 'talvez essa ambigüidade tenha aumentado a aceitabilidade do Código entre os advogados das diferentes nações, porque cada um pode ler nessas disposições as suas próprias pressuposições'. Isso, porém, seria uma miragem legislativa, aparecendo a alguns mas não a outros, podendo assumir qualquer forma desejada pelo usuário. $\mathrm{O}$ fato de o texto ter sofrido influência predominantemente européia, por sua vez, dificulta sua aceitação por parte dos Estados Unidos, cuja base legislativa, por força de sua jurisprudência, é mais 'econômica' - vale dizer, a lei é aplicada segundo uma projeção das prováveis consequiências econômicas produzidas pela prática analisada -, ao passo que a legislação européia tem caráter mais conceitual" (ANA MARIA NUSDEO, op. cit., p. 168-169). No mesmo sentido: "The very exercise of drafting a highly articulated code (e.g., the Munich Code) reveals its limits. There is no one acceptable set of detailed antitrust rules in the world, except at the highest level of generality. Many rules in the Munch Code would be entirely unacceptable to many nations. For example, the proposed rule on breakups, vertical restraints and abuse of dominance would be unacceptable to (at least) the United States. This is not a flaw that can be cured by a few deletions and generalizations. Any writing of a set of detailed rules (e.g., in abuse of dominance, intellectual property, market foreclose) may accord with the needs and contexts of some nations at the time, but will not accord with the needs and contexts of others, and will not satisfy nations needs through time" (ELEONOR M. FOX, op. cit., p. 2).
} 
interesse dos países em desenvolvimento uma discussão séria sobre o que a aceitação desses termos representará para a condução de suas políticas econômicas e comerciais.

\subsubsection{Do comportamento dos Estados}

A eficácia de qualquer legislação depende da atuação dos agentes no sentido de promovê-la e torná-la respeitada. Do ponto de vista prático, de nada adianta a mera existência do texto legal se ele não produz os efeitos desejados.

A mesma lógica pode ser aqui empregada: seria necessária a atuação positiva dos Estados para que os termos de uma legislação internacional fossem cumpridos. Não há dúvidas de que, para que realmente ocorra a harmonização, inúmeras alterações nas legislações concorrenciais e nas políticas comerciais e industriais de países seriam necessárias. Este é sem dúvida um primeiro ponto a desafiar a existência de tais normas.

Um segundo ponto seria a necessidade de colaboração dos países para a condenação de práticas perpetradas em seus territórios e, por vezes, por suas próprias empresas. A colaboração estaria não apenas na licença para que tais empresas fossem processadas, mas também, na autorização para a coleta de provas, entre outras atividades. Uma discussão mais aprofundada sobre essa problemática terá lugar no Capítulo 5.

Como já se afirmou, inúmeras das práticas tidas como anticoncorrenciais que ocorrem no âmbito internacional são realizadas com o autorização ou conhecimento dos próprios Estados. A esse respeito, DOUGLAS ROSENTHAL afirma que, ao contrário do que normalmente se acredita, podemos encontrar mais práticas anticompetitivas viabilizadas pelos próprios governos do que práticas não competitivas orquestradas pelos agentes privados ${ }^{179-180}$. Assim, a despeito dos inflamados discursos pela aplicação dos

179 DOUGLAS ROSENTHAL, Relationship of U.S. Antitrust Laws to Formulation of Foreign Economic Policy, Particularly Export and Overseas Investment Policy, In 49 Antitrust L.J. 1189, 1980, p. 1192. Ainda a esse respeito, veja-se o relato de ALEXIS JACQUEMIN, afirmando que uma dos maiores problemas encontrados para a quebra do cartel, qual seja, a dificuldade de coordenação entre as muitas firmas, é neutralizado pela autorização governamental para a sua criação (ALEXIS JACQUEMIN, TSURUHIKI NAMBU e ISABELLE DEWEZ, op. cit., p. 686).

180 "The incentive of governments to use such instruments [tariffs and nontariff trade barriers] is explained by strategic trade theory (STT), pointing out that government intervention in free trade can provide opportunities for selected industry sectors to expand markets and thereby increase national income" (FLORIAN BECKER, op. cit., p. 98). 
postulados do livre comércio e para a adoção de políticas uniformes da concorrência, não é raro que os próprios países desenvolvidos não colaborem para a constituição de tal ideal. Em situações como essa parece ser clara a aplicação da máxima: "Keynes at home, Smith abroad" $" 181$.

Os cartéis de exportação são claro exemplo de estruturas consideradas anticoncorrenciais que contam com a participação (ou autorização) dos países na sua formação. O glossário de termos da Organização para a Cooperação e Desenvolvimento Econômico- OCDE os define como "cartéis públicos", em referência a essa participação: "A distinction needs to be drawn between public and private cartels. In the case of public cartels, the government may establish and enforce the rules relating to prices, output and other such matters. Export cartels and shipping conferences are examples of public cartels" vêzes, então, os cartéis tomam caráter público: são estabelecidos pelos Estados e às vezes, até obrigatóriamente impostos pelas autoridades públicas. Isto basta para demonstrar a complexidade do problema"183.

\subsubsection{Do controle}

Podemos ainda pensar em um terceiro fator a trazer dificuldade para a adoção de uma "política internacional da concorrência". Examinamos acima que a colaboração dos Estados seria essencial para que essa política pudesse ser efetiva, por exemplo, em matérias como a coleta de provas. Talvez fosse necessária a criação ou a eleição de uma autoridade responsável pela legislação concorrencial internacional.

Tal organismo deveria ser uma entidade internacional, reconhecida pelos países como isenta e apta para a aplicação do direito. A Organização Mundial do Comércio OMC é hoje responsável pela "regulação" do comércio entre os países e, nessa medida,

181 Expressão utilizada por WELBER BARRAL, Secretário de Comércio Exterior brasileiro na I Conferência Internacional de Defesa da Concorrência do SBDC, realizada em 15 e 16 de outubro de 2009. A referência toca às políticas defendidas por John Maynerd Keynes e por Adam Smith, em muitos pontos, antagônicas.

182 Disponível em; http://www.oecd.org/dataoecd/8/61/2376087.pdf, acesso em 20 out. 2009.

183 Ensaios e Pareceres, São Paulo, Saraiva, 1952, p. 224. 
poderia ser uma das candidatas a ocupar esse posto. Ocorre que as disputas entre os Estados dentro dessa entidade são enormes, o que poderia gerar questões insuperáveis sobre sua isenção ${ }^{184}$. Ainda que se chegasse a um consenso sobre a autoridade responsável pela lei concorrencial, podemos supor que existiriam grandes discussões sobre a forma como deveria se dar a representação dos países em seus bancos e sobre as linhas de interpretação a serem seguidas ${ }^{185}$.

Ademais, para que a lei pudesse ser aplicada de forma satisfatória, seria necessário atribuir à autoridade antitruste poderes suficientes para fiscalizar a atividade das empresas e dos países e a eles aplicar sanções. Como sabemos, um dos grandes problemas do direito concorrencial é a coleta de provas. Especialmente com relação aos cartéis, há a célebre dificuldade para se encontrar as evidências de conluio necessárias para processar as empresas e pessoas físicas dele participantes.

Se a busca por provas já é difícil em território nacional, o que dirá no âmbito internacional? Não há dúvida sobre a polêmica que surgiria em muitos aspectos desse procedimento, mas especialmente com relação a definição sobre: i) quais informações deveriam/poderiam ser repassadas ao órgão julgador; ii) como essas informações seriam coletadas; e iii) como ocorreria o acesso de outros países a esse tipo de informação, entre outros pontos de discórdia.

\footnotetext{
184 "It seems unlikely that a competition agreement in the WTO could help overcoming Northern government's unwillingness to prosecute export cartels or to share information with developing countries antitrust authorities. On the contrary, the proponents of multilateral competition rules primarily aim at further market access opportunities" (THOMAS FRITZ, The wrong forum: competition policy in the WTO, disponível em: http://www.blue21.de/PDF/S2B-Competition-Policy.pdf, acesso em: 10 out. 2008). Ainda sobre a OMC: "The most obvious candidate for international oversight is the WTO. No other international forum is as well qualified, and to create a new international forum would be a very difficult task. However, there are powerful objections to the WTO adopting an oversight role in respect of a GCA. First, there is a concern that WTO panels will be ill-equipped to make proper assessments about competition laws, competition cases and the performance of national competition authorities. [...] Secondly, there is concern that the WTO already has a heavy workload dealing with traditional market access issues. A competition agreement would simply be a further distraction. Extending the range of WTO complaints to include failures to discipline private import restraints could radically increase the number of WTO actions, particularly if such actions are viewed as strategically useful in the leveraging market access. As competition cases are often complex and lengthy, this will put an increased burden on the WTO adjudication system. Many believe the system is nor ready for that burden. Thirdly, as with any international agency, the WTO suffers from perceptions of capture and illegitimacy. These perceptions may be stronger for the WTO than for other institutions such as the ICN because of the WTO's much more extensive powers. Finally, there is a danger that subjecting competition principles to adjudication by a trade body will lead to a corruption of those principles" (BRENDAN J. SWEENEY, op. cit., p. 219 e 220).
}

185 "Attempts to use the legal regime of the WTO to overcome private restrictions of competition are likely to fail, because of the fundamental differences between trade policy and competition policy" (FLORIAN BECKER, op. cit., p. 97). 
É importante que se perceba que, caso a "política internacional da concorrência" viesse a ser aceita, em muitos casos, o Estado seria obrigado a produzir provas para processar e condenar suas próprias empresas, o que, em termos práticos, não parece crível. Apenas a título ilustrativo, devemos nos lembrar que, nos dias atuais, a troca de informações confidenciais entre as autoridades antitruste é realizada de forma bastante cuidadosa, demandando uma série de acordos internacionais, como aqueles a que o Brasil vem atualmente se submetendo ${ }^{186}$.

A criação de uma autoridade internacional de concorrência, entretanto, pode ser examinada de uma forma mais otimista para os países em desenvolvimento: segundo AJIT SINGH, poderia ser uma forma de controlar a atividade dos países centrais e de proporcionar mais competição para os países em desenvolvimento.

A idéia defendida por ele é a de que uma autoridade antitruste internacional não teria como função a aplicação indistinta das regras do livre comércio e da livre concorrência. Ao contrário, deveria controlar e supervisionar as estruturas existentes no mercado internacional, impedindo o surgimento de gigantes, que trazem profundas alterações na dinâmica do comércio internacional. Dessa forma, sua principal atividade seria o controle dos processos de fusão e incorporação de empresas no cenário internacional (sobre esse assunto, bastante afeto aos pressupostos da Escola de Harvard, consultar o Capítulo 2) ${ }^{187}$.

Por trás desse pleito está implícita a necessidade de manter condições justas de concorrência na arena internacional, o que muitas vezes não é viável, tendo em vista as diferenças econômicas entre os países e a concentração característica do mercado internacional $^{188}$.

\footnotetext{
186 Nesse sentido, verificar acordo firmado com a União Européia no dia 08 de outubro de 2009, conforme matéria disponível em http://blog.planalto.gov.br/acordo-com-uniao-europeia-fortalece-combate-acarteis-no-brasil/, acesso em 14 out 2009.

187 Obviamente, se o crescimento ocorrer internamente, sem a compra de outras empresas, não haverá que se falar em qualquer tipo de controle.

188 Exposição de AJIT SINGH, Professor da Universidade de Cambridge, durante o seminário "Os desafios do crescimento durante o século XXI” (MANUEL ALVES FILHO, op. cit.)
} 


\section{OS CARTÉIS DE EXPORTAÇÃO - A POLÊMICA - SEGUE}

\subsection{Cartéis de exportação são realmente um problema?}

Diante das discussões travadas até o momento esperamos ter restado claro que:

i) os cartéis de exportação são formas de incentivo às exportações e diferenciam-se dos cartéis clássicos por dois motivos em especial: a autorização Estatal e a possibilidade trazerem benefícios que os justificam; e

ii) existem questões externas (como a busca pela harmonização das leis concorrenciais) que podem afetar a decisão de se adotar os cartéis de exportação.

É hora, portanto, de verificar se os cartéis de exportação são efetivamente um obstáculo ao livre comércio ou se as críticas a eles efetuadas podem ser consideradas censuras generalizadas a qualquer tipo de intervenção do Estado na economia.

Para tanto, devemos voltar ao problema da ausência de dados sobre os cartéis de exportação. Vimos, ao longo do Capítulo 4, que a forma pela qual os países permitem a sua utilização pode ser uma maneira de mascarar a real emprego desse instrumento de fomento. Nos países nos quais a isenção é implícita, mal podemos avaliar se as associações para exportação são efetivamente usadas. Já nos que concedem autorizações explícitas, enfrentamos o problema de nem sempre serem requisitadas informações ou o seu registro o que, ao final do dia, impede que tenhamos dados fidedignos.

Nos resta, portanto, trabalhar com as informações colhidas nos ordenamentos que conferem isenção explicita aos cartéis de exportação e nos quais é necessário o registro. É o caso dos Estados Unidos, onde aparentemente poucas empresas procuram abrigo nos termos do Webb-Pomerene Act (para mais informações consultar o item 6).

A corroborar a evidência de baixa utilização, contamos com as parcas reclamações acerca de problemas advindos de sua existência. Quando encontramos referência aos cartéis de exportação, usualmente estão imiscuídas em longas listas descrevendo práticas tidas como anticompetitivas. Uma possível motivação para a falta de protestos pode estar 
no fato de essas isenções serem geralmente utilizadas por países desenvolvidos, como os Estados Unidos e a União Européia. Caso fossem maciçamente utilizadas por países em desenvolvimento, a realidade poderia ser diversa.

A falta de dados nos traz ainda um outro problema: trata-se da impossibilidade de se verificarem seus reflexos na dinâmica concorrencial. É muito difícil se comprovar, além dos modelos matemáticos e econômicos, que a união de exportadores pode ser prejudicial ao comércio entre países e, além disso, calcular quais seriam os valores envolvidos nesse prejuízo. Por outro lado, também é bastante complexa a comprovação de possíveis benefícios trazidos para os consumidores internacionais. As vantagens que encontramos internamente, no entanto, podem ser mais facilmente calculadas, tendo em vista a possibilidade de se verificar os incrementos da atividade interna resultado do maior volume de exportações.

Dentro de todas as dúvidas aqui levantadas, e de dados tão escassos, acreditamos que seria precipitado abri-se mão desse instrumento de fomento à exportação, tendo em vista todos os pontos favoráveis estudados no Capítulo 4. Ainda, o uso incessante desses instrumentos, por países como os Estados Unidos e o Japão, podem ser um bom indicador de que, se bem manejados, podem fazer parte de uma política maior de desenvolvimento $^{189}$.

\subsection{Conveniência da adoção}

É chegado agora o momento de refletir sobre o real interesse dos países em se aceitar a harmonização das normas concorrenciais. Como já discutimos no Capítulo 5,

$189 \quad$ No resumo de DANIEL SOKOL: "Without an understanding of the problem of export cartels and its scope, any serious discussion of export cartels may be a solution in search of a problem. Countries with explicit export cartel immunities other than the United States lack transparency and available data to detail the nature of the export cartel immunity. Indeed, even the empirical work on U.S. export cartels reveals a limitation of data to fully understand export cartels. This creates difficulties in determining how much anticompetitive harm an export cartel may create. Even worse, in countries with implicit exemptions the collection of data and transparency is next to impossible. Where there is no notification because the export cartel immunity is implicit, it is difficult to determine even the existence of the cartel let alone the scope of the export cartel and whether it has hard core cartel attributes. Given the data collection problems in jurisdictions that have implicit immunities, understanding the extent of the spillover effects of export cartels across jurisdictions is even more difficult to determine. The lack of empirical data suggests that global solutions on export cartels may be based more on theory them empirical evidence and therefore not well suited for situations in which the very assumptions behind such theories may be misguided" (DANIEL SOKOL, op. cit., p. 5). 
afirma-se que a maior interação econômica entre os países, característica das últimas décadas, traria consigo a necessidade de normas concorrenciais similares, que fossem hábeis a resolver conflitos envolvendo mais de uma jurisdição e que estabelecessem padrões comuns de comportamentos. Esses objetivos, que a princípio poderiam parecer benéficos, trazem consigo um emaranhado de questões a serem estudadas atentamente antes da tomada de qualquer decisão.

Sumariamente, podemos elencar algumas questões que deveriam ser foco de atenção, entre elas os parâmetros sobre os quais seria erigida a legislação comum e a forma como a atuação do Estado na economia seria tratada. Vamos cuidar de cada um deles.

Já se disse, mais uma vez, que com a hegemonia conquistada pela Escola de Chicago nas últimas décadas e a influência que o direito concorrencial norte-americano vem ganhando, é bem possível que se busque a harmonização da legislação concorrencial tendo em vista os ideais daquela Escola. Isso nos remonta a duas importantes questões, já previamente abordadas: a primeira, relativa à eleição de um único objetivo para o direito antitruste; a segunda, relativa ao papel que é reservado ao Estado.

A eleição de um único objetivo para o direito concorrencial é cercada de controvérsia, especialmente para os países em desenvolvimento. Retomando o quando verificamos no Capítulo $2^{190}$, acreditamos que o direito concorrencial, como importante instrumento de atuação no mercado, deve se coadunar com outras políticas públicas para a consecução de fins estabelecidos, no caso brasileiro, constitucionalmente. Dessa constatação, logicamente, emerge a impossibilidade de termos a eficiência alocativa como único norte para essa legislação ${ }^{191}$.

Especialmente para os países em desenvolvimento, a aceitação dos padrões chicagueanos, seria abrir-se mão da possibilidade de utilizar-se o instrumento para a construção de um desenvolvimento sustentável, tendo em vista eficiências dinâmicas e não

190 Afirmamos no Capítulo 2 que acreditamos que o direito antitruste deva ser tomado como forma de implementação de políticas públicas. Nessa medida, sempre integrado ao restante do ordenamento jurídico, suas normas se prestam a atingir objetivos traçados para determinado país, em determinado momento histórico. Assim, não há que se falar em uma "atuação isolada" da disciplina antitruste.

191 " [...] it is argued that many developing countries cannot aspire to the kind of competition policies which advanced countries implement. More importantly it is suggested that it is not, in any case, in the interest of developing countries to do so. Competition policies for advanced countries are shown not to be appropriate for the stage of development of most developing countries" (AJIT SINGH, Competition Policy, development and developing countries, cit., p. 2). 
as estáticas. Não podemos nos esquecer que a agenda hoje proposta pelos países desenvolvidos não foi concebida de um momento para outro. Ao contrário, reflete décadas (ou séculos) de desenvolvimento econômico. É de se notar, a esse respeito, que países como a Alemanha e o Japão, que atravessaram um período de industrialização considerado tardio (em comparação com a industrialização da Inglaterra e mesmo dos Estados Unidos), sempre tiveram como traço marcante de suas economias uma forte intervenção do Estado na economia como coordenador de políticas industriais, econômicas e relativas a matérias concorrenciais, como se poderá observar no Capitulo 6.

No Capítulo 7 teremos a oportunidade de discutir os objetivos traçados pela Constituição Federal para a República Federativa do Brasil. De uma breve leitura percebese que as metas impostas pelo legislador refletem as necessidades de um país em desenvolvimento, que necessita, por exemplo, "construir uma sociedade livre, justa e solidária”. Não podemos aceitar a imposição de uma política externa que retira das nossas normas concorrenciais a possibilidade de serem utilizadas como ferramentas para a consecução das políticas públicas desenhadas para nosso país.

Assim, acreditamos que as políticas concorrenciais devam refletir a realidade social e econômica de cada Estado, não estando previamente vinculada a qualquer padrão externo que a torne discrepante do resto do ordenamento jurídico. Discordando de ELEONOR M. FOX, não creditamos que "we need a vision of liberal antitrust to fit the worldview of liberal trade" ${ }^{192}$.

Em relação específica aos cartéis de exportação, não há duvidas de que poderiam estar inseridos na política interna de um país, que pretende, por exemplo, fomentar a aquisição de seus bens no mercado externo ou simplesmente aumentar o grau de competitividade das empresas, tendo em vista o tamanho das empresas transnacionais. A utilização desse tipo de instrumento, no entanto, poderia ser seriamente desafiada por qualquer tentativa de uniformização das leis concorrenciais que levasse em conta unicamente o ideal de eficiência alocativa.

Há ainda uma outra questão, que emerge da possível aceitação de uma mesma política antitruste - imutável - para todos os países. Como se observou, os teóricos neoclássicos acreditavam que as leis econômicas são leis naturais, sendo hábeis a explicar $192 \quad$ Op. cit., p. 2. 
qualquer fenômeno, ainda que ele ocorra dentro das mais variadas realidades. Um exemplo da aplicação dessa teoria no ilustra como ela pode ter efeitos bastante diversos nos países que a elas se sujeitam ${ }^{193}$.

A Teoria das Vantagens Comparativas foi largamente aplicada pela teoria neoclássica para o comércio internacional. Entendia-se que o custo de oportunidade e a expertise dos países determinariam o que cada um deles deveria comercializar com os demais. Por meio dessa divisão, haveria o aumento da produção total da economia e, assim, do total de riqueza gerada. Não havia preocupação com a forma de distribuição dessa riqueza, apenas com o aumento de seu volume total, o que - segundo esses doutrinadores - corresponderia ao aumento do bem-estar do consumidor.

A divisão da riqueza, entretanto, seria realizada de forma benéfica aos países centrais. Por serem países com maior tradição comercial e por contarem com uma indústria mais consolidada e estruturada, é de se imaginar que os bens industrializados por eles produzidos contem com vantagens (como valores inferiores, melhores tecnologias, maior economia de escala e de escopo) em sua produção se comparados aos bens produzidos em países em desenvolvimento. Assim, por terem a "vantagem comparativa", a produção desses bens deveria ser deixada para os países desenvolvidos. Por outro lado, a produção de bens que demandam menor tecnologia, mas que tenham necessidade de mão-de-obra mais intensiva (como os agrícolas e os semi-manufaturados), deveria ser deixada a cargo dos países em desenvolvimento, que possuem maior "vantagem comparativa" em sua produção ${ }^{194}$. A toda evidência, a depender dessa linha de argumentação, os países

193 Os postulados da Teoria Neoclássica para os países da América Latina estão especialmente ligados ao rígido controle da inflação por meio do controle da moeda e a aplicação de reformas institucionais destinadas à redução da participação do Estado na economia. LUIZ CARLOS BRESSER-PEREIRA assim a resume: "A ortodoxia convencional [...] não havia sido elaborada no país e não refletia as preocupações nem os interesses nacionais, mas as visões e os objetivos dos países ricos. Além disso, como é próprio da ideologia liberal, era uma proposta negativa que supunha a possibilidade de os mercados coordenarem tudo automaticamente, alem de proporem que o Estado deixasse de realizar o papel econômico que sempre exerceu nos países desenvolvidos: o de complementar a coordenação do mercado para promover o desenvolvimento econômico e a equidade". (O novo desenvolvimentismo e a ortodoxia convencional, cit., p. 9).

194 "De acordo com a teoria do livre-comércio, seja na versão ricardiana ou na HOS, todo país tem uma vantagem comparativa em alguns produtos, ou seja, é relativamente melhor ao produzir algumas coisas em comparação aos outros países. Na teoria HOS, um país tem vantagem comparativa em produtos que usam mais intensivamente o fator de produção com o qual ele é relativamente mais dotado. Então, mesmo que a Alemanha, um país relativamente mais rico em capital do que em trabalho, possa produzir carros $e$ bichos de pelúcia, de forma mais barata que a Guatemala, é conveniente que ela se especialize em automóveis, uma vez que sua produção usa capital de forma mais intensiva. A Guatemala, mesmo que seja menos eficiente ao 
periféricos continuariam eternamente em posição de dependência econômica em relação aos países centrais, visto que os termos da troca são eminentemente desiguais ${ }^{195}$.

Para que situações como essa não se perpetuem, entramos em nosso segundo ponto de preocupação, que é o do papel reservado ao Estado. Observamos que esses teóricos compreendem o Estado, como mero corretor de falhas de mercado, devendo se manter o mais afastado o possível de assuntos que possam afetar a economia e o comércio.

Para os países em desenvolvimento, essa idéia pode se revelar bastante perigosa, porquanto a realidade econômica e social de pobreza, subdesenvolvimento e desigualdades demanda a ação do Estado como condutor do processo de desenvolvimento. Nas palavras de LUIZ CARLOS BRESSER-PEREIRA: "Uma estratégia nacional de desenvolvimento não é outra coisa senão uma instituição estratégica, uma instituição chave: é o conjunto de objetivos, normas, políticas públicas, práticas privadas, entendimentos compartilhados e acordos políticos que orientam o comportamento dos agentes econômicos ao criarem oportunidades de investimento e ao estimularem o trabalho e a inovação ${ }^{196,}$.

Ou seja, a ação do Estado é chave dentro do processo de desenvolvimento. Qualquer "inibição" trazida pela norma externa poderia prejudicar essa atuação, na medida em que retiraria do Estado a autonomia de que necessita para formular sua estratégia de desenvolvimento.

A questão sobre os limites da intervenção do Estado na economia são bastante antigas e tormentosas. Em um breve retrospecto, podemos afirmar que não há consenso nas teorias econômicas sobre a melhor forma de lidar com a questão, visto já terem variado de um extremo a outro. No período mercantilista falava-se em completo apoio à intervenção do Estado, o que passou a ser rejeitado pelas idéias trazidas por ADAM SMITH. A crise dos anos 1920 e a depressão por que passaram os países justificou uma nova onda intervencionista, apoiada nas idéias de JOHN MAYNARD KEYNES. Os anos 1980, por

produzir ambos os itens - automóveis e bichos de pelúcia - do que a Alemanha deveria especializar-se em bichos de pelúcia, cuja produção usa mais trabalho do que capital" (HA-JOON CHANG, op. cit., p. 67).

195 "Global trade has generally been recognized as building increase choice, more efficient production, and still greater wealth. The rather obvious corollary proposition is that in order to international trade to act as the lever, helping to ratchet up global living standards, full and free competition must prevail" (ERIK JOHANSEN, op. cit. p. 332). 
sua vez, foram responsáveis por uma onda liberalizante nos mercados, que parece ter se perpetuado até a crise do ano 2008.

A principal questão que emerge desse emaranhado de teorias econômicas é: os agentes privados são capazes de alocar os escassos recursos disponíveis no mercado para a consecução dos fins almejados pela sociedade como um todo ou é necessária a intervenção do Estado para que isso seja possível? Para os objetivos deste estudo, a discussão pode ser resumida no embate entre três correntes ideológicas que se digladiam sobre o papel do Estado na política industrial: i) a corrente clássica; ii) a corrente desenvolvimentista; e iii) a corrente da inovação.

Como seria de esperar, a corrente clássica está apoiada nos ensinamentos dos clássicos, que pregam a mínima intervenção estatal na economia. Assim, a atuação do Estado na política industrial estaria limitada àquelas situações nas quais fosse detectada alguma falha de mercado. Somente essas situações justificariam a ação direta do Estado. Um exemplo de tal falha ocorreria quando os agentes privados preferissem investir em setores nos quais obtivessem retornos mais rápidos em vez de setores, como os de pesquisa e desenvolvimento, no qual o retorno costuma ser mais demorado e arriscado.

A óptica desenvolvimentista, por outro lado, procura desnudar o estágio de desenvolvimento de cada país para então decidir qual seria o nível de intervenção adequada para aquela situação. Países com desenvolvimento tardio justificariam a atuação mais efetiva do Estado, enquanto países com processo de industrialização completa não teriam essa justificativa. A principal preocupação desses pensadores está na proteção e promoção das indústrias nascentes, que não seriam capazes de competir com as indústrias já estabelecidas.

Já a última corrente, a da inovação, está vinculada aos ensinamentos que nos foram trazidos por J. SCHUMPETER e a importância que esse autor confere para os processos de inovação tecnológica como forma de desenvolvimento. O Estado, nesse passo, teria a função de incentivar a atividade inventiva e colaborar para que seja difundida pela sociedade, gerando maiores oportunidades de desenvolvimento. Nesse rol de incentivos estariam os subsídios, os financiamentos e os incentivos para a capacitação tecnológica. A atuação do Estado seria necessária, tendo em vista o fato de essas atividades de pesquisa e 
desenvolvimento serem repletas de riscos e demandarem grandes investimentos financeiros ${ }^{197}$.

Para os Estados em desenvolvimento, certamente, a opção pelo modelo clássico não parece ser adequada a sua realidade. Mais uma vez, reafirmamos, junto com GILBERTO BERCOVICI, que o Estado deva desempenhar um destacado papel na busca pelo desenvolvimento econômico: "O Estado é o principal formulador de políticas de desenvolvimento, ao introduzir a dimensão política no cálculo econômico, em busca da constituição de um sistema econômico nacional. O processo de formação de políticas públicas, de acordo com Lourdes Sola, é o resultado de uma complexa e dinâmica interação de fatores econômicos, políticos e ideológicos. O papel político do Estado é central nesse processo, contrariando a visão corrente da análise econômica que considera o Estado apenas uma categoria residual". ${ }^{198}$.

Ou seja, o Estado deve ser capaz de formular políticas públicas na busca dos objetivos para ele traçados. Nesse sentido, é impensável aceitar que uma legislação internacional se sobreponha à utilização do direito concorrencial como uma das ferramentas para essa busca. A questão que ainda permanece sem resposta é o nível de intervenção adequada para cada um dos Estados e a forma pela qual esse processo ocorre. Para tanto, é necessário que existam diretrizes básicas para a atividade, sob pena de incorrermos em falta de segurança para a sociedade.

Um bom exemplo da necessidade de atuação está no desenvolvimento de setores que demandam altos investimentos, especialmente os de alta tecnologia. Para ilustrar essa situação, imaginemos o seguinte: uma indústria no interior paulista está disposta a investir pesado em tecnologia para o desenvolvimento de um processador a ser utilizado nos computadores. Sem qualquer atuação do Estado no sentido de promover esse setor e apoiar seu desenvolvimento (seja na forma de cotas para importação, criação de um cartel de exportação, subsídios, ou qualquer outra), a empresa nascente teria que se deparar com a violenta concorrência de empresas como a Intel, presente em todo o mundo e detentora de

\footnotetext{
197 Para questões mais aprofundadas, consultar DAVID KUPFER e LIA HASENCLEVER, op. cit.

198 MARIA PAUla DALlari BUCCI (org.) Políticas Públicas, São Paulo, Saraiva, 2006, p.143. Ainda nesse sentido, LUIZ CARLOS BRESSER-PEREIRA: "Para que o desenvolvimento econômico ocorra é necessário que o Estado, na sua qualidade de instituição maior e matriz das demais instituições, seja forte, capaz: tenha legitimidade e capacidade para formular políticas, cobrar impostos e impor a lei" (Desenvolvimento Econômico e Revolução Capitalista, cit., p. 19).
} 
tecnologia de ponta para a produção desses produtos. Seria natural supor que, nessas condições a concorrência seria impossível de ser enfrentada pela empresa nacional, que se depararia, ao longo dos anos, com produtos mais baratos e mais sofisticados produzidos pela transnacional. $\mathrm{Na}$ falta de políticas de apoio à indústria nacional teríamos a dependência eterna do Brasil com relação aos processadores produzidos fora do país. O exemplo, embora focado no campo da informática, serve para ilustrar a importância do Estado como propulsor do surgimento de indústrias nacionais fortes, capazes de concorrer na arena internacional ${ }^{199}$.

A busca pelo fortalecimento da indústria se justifica por inúmeros motivos, seja pelo fomento da atividade interna, seja pelo fato de o mercado internacional estar dominado por empresas de incrível poderio econômico. Sem o apoio dos Estados, em muitos casos, não há que se falar em capacidade para competição externa, sendo necessária a interferência para que a ela possa ser mantida e desenvolvida. Se os Estados desfrutassem de níveis de desenvolvimento industrial e econômico minimamente equalizáveis, poderíamos até pensar na possibilidade de que as regras pudessem ser benéficas aos países em desenvolvimento, mas não é essa a realidade. No extremo, podemos nos indagar a quem seria benéfico o livre comércio entre os Estados Unidos e um país africano de baixo desenvolvimento.

A toda evidência, a adoção de uma "política internacional da concorrência" nesses termos seria uma maneira de utilizar-se a legislação concorrencial para que os Estados tivessem menor ingerência na condução dos negócios internacionais e na disputa concorrencial. Ocorre que o Estado, ao abrir mão da possibilidade de interferência no mercado, deixaria de contar com uma arma bastante poderosa, tendo em vista a já

\footnotetext{
199 "O padrão de concorrência entre os agentes também se altera nesse contexto. Assim, além da capacidade de investimento em pesquisa tecnológica e inovação e de expansão para novos mercados, a necessidade de competir em igualdades de condições com agentes de atuação global tem levado a um processo de intensa concentração de empresas. Essa tendência decorre, além disso, da intensificação da concorrência, resultante da abertura de muitos mercados, antes protegidos à concorrência internacional. Existe um acirramento da concorrência, não apenas em preços, mas em inovação, pesquisa e desenvolvimento, criação de linhas de produto-prêmio, marcas, atendimento ao cliente, assistência técnica de fatores que tais. Em consequiência disso, muitas empresas vêem-se forçadas a sair do mercado ou a se associar com outras para melhor enfrentar as novas condições de concorrência. Desse processo resultam, muitas vezes, as chamadas megafusões, envolvendo dois concorrentes vultosos em mercados nacionais, atuando também internacionalmente" (ANA MARIA NUSDEO, op. cit., p. 145).
} 
mencionada interação entre a disciplina antitruste e outras áreas de atuação do Estado, como as políticas industriais e comerciais ${ }^{200-201}$.

Nessa esteira, devemos adentrar um pouco no conceito de globalização, introduzido no Capítulo 5. A existência de maior facilidade de comunicação e de interação entre os países, resultado do desenvolvimento tecnológico das últimas décadas, parece estar sendo utilizada de forma perigosa, emprestando à chamada globalização extensão maior daquela que possui: com efeito, quer-se transformar o estreitamento das relações em um marco para uma pretendida alteração na ordem internacional, inclusive com mudanças nos conceitos de soberania.

É interessante notar como esse processo é bem trabalhado, principalmente pela mídia, que não se cansa de exaltar as mudanças trazidas pelo fenômeno, transmitindo a idéia de que vivemos em um mundo no qual é inadequado pensar em divisões entre países. Esse esforço midiático sobre a população leva a globalização a ser tratada no dia-a-dia das pessoas como um fato natural, a ser aceita sem maiores questionamentos. Em uma análise mais detida, entretanto, não podemos nos esquecer das inúmeras ideologias que estão por trás da aplicação desse conceito. Uma delas, sem dúvida, é a luta pelo livre comércio

Observe-se que as duas idéias são efetivamente complementares: se as teorias neoliberais pretendem a livre circulação de mercadorias no globo, sem qualquer interferência dos Estados, as da globalização tomam como certa uma nova forma de enxergar o mundo, baseada na diluição das barreiras entre Estados. Para que os países possam adequar-se a essa nova "realidade" é necessário que adotem medidas no sentido de liberalizarem as suas economias, permitindo maior integração no comércio internacional.

200 ADITYA BHATTACHARJEA, Export cartels, a developing country perspective, cit., p. 95. Idéia confirmada por HIROKO YAMANE, que afirma que a relação entre o comércio e as leis antitruste são bastante complexas (Trade and competition in the Japanese experience, In 2 J. Int'l Econ. L., 1999, 537$545)$.

201 BRENDAN J. SWEENEY relata como são percebidos os "obstáculos" trazidos pelos países em desenvolvimento para a criação da "política internacional da concorrência": A major impediment to any GCA on private import barriers is the attitude of the developing states. The developing states demonstrated at Cancun that competition issues are far from the top of their list of priorities. They are suspicious of the motives of developed states. For example, the push for global rules against private trade barriers is seen by some developing states as an attempt by the developed states to control the growth of significant firms in the less developed economies. Alternatively, it is just another way to prize open foreign markets. According to UNCTAD Report 'a key concern of developing countries [in removing competition policy from the DOHA Work Program] was that a multilateral framework at the WTO might be used as a means of securing increased access to developing-country markets". (Op. cit., p. 221). 
É difícil se aceitar as idéias da forma pela qual estão sendo propagadas, especialmente a de que os Estados-Nação perderam a sua autonomia e relevância: mercados livres no âmbito mundial, inclusive os financeiros, se encarregariam de promover o desenvolvimento econômico de todos ${ }^{202}$. Como se observou no singelo exemplo acima sobre os processadores, para os países que não alcançaram níveis econômicos satisfatórios, a atuação do Estado é imprescindível para que possam ter condições de crescimento e concorrência no mercado internacional. O Estado deve ser um agente forte na condução da economia e não deve ter a sua atividade refreada pela pela norma concorrencial internacional.

Se a autonomia decisória com relação ao aspecto comercial não fosse concedida ao Estado, teríamos a eterna perpetuação dos termos de troca observados no comércio internacional. Os países que exportam produtos sofisticados e de alto valor agregado permaneceriam eternizados nessa posição, porquanto jamais enfrentariam a concorrência de outros players, impossibilitados de colocarem os seus países em condições de desenvolvimento que lhes permitam concorrer com a indústria já preestabelecida. Restará a esses países a comercialização de produtos menos elaborados e que, por esse motivo, possuem menor valor no comércio internacional ${ }^{203}$.

É interessante reformarmos o entendimento de BRENDAN J. SWEENEY (nota 163), segundo o qual o objetivo "política internacional da concorrência" seria o de superar problemas encontrados na legislação nacional como, por exemplo, o protecionismo. Seria realmente do interesse de países como o Brasil que legislação internacional fosse capaz de impedir que se tomassem medidas protetivas às suas empresas? AJIT SINGH nos traz um ponto para reflexão: "As in other areas of international trade and related matters, the advanced industrial countries are seeking what they refer to as 'legal playing fields', so that their corporations can have free and open Access to developing economies. The firms

202 LUIZ CARLOS BRESSER-PEREIRA, O novo desenvolvimentismo e a ortodoxia convencional, cit., p. 8 .

203 "De fato os países de tornaram mais interdependentes e perderam parte de sua autonomia na definição de políticas, mas a interdependência não decorreu da cooperação, mas da competição, de forma que a autonomia nacional é hoje mais estratégica do que em qualquer outro tempo para que a Nação continue a se desenvolver. Os Estados-nação são hoje mais relevantes do que nunca, porque eles são o instrumento de ação coletiva de que dispõem as nações para competirem internacionalmente. O pensamento hegemônico afirma a irrelevância das nações, mas o globalismo é apenas uma estratégia das nações mais fortes e ricas para neutralizar os adversários que buscam o catch up no quadro de competição global que é o desenvolvimento econômico" (LUIZ CARLOS BRESSER-PEREIRA, Desenvolvimento econômico e revolução capitalista, cit., p. 15). 
in the latter countries, however, are relatively small with relatively little experience and, unlike the large established foreign firms with world-wild presence, do not have the same access to finance and lack the less tangible but critical assets as brand recognition or global marketing networks. The establishment of 'level playing fields would prohibit developing countries both from taking measures to shield their firms and industries from competition from massive foreign corporations and from pursuing measures to promote growth of strong domestic corporations" ${ }^{, 204}$.

Com efeito, o que se parece observar é que a adoção de políticas comuns no campo concorrencial atenderá muito mais a interesses de países desenvolvidos, que anseiam por amplo acesso aos mercados de países em desenvolvimento. Uma vez tendo alcançado o 'level playing fields', certamente caracterizado pela ausência daquilo que SWEENEY denominou de "problemas como o protecionismo" as empresas dos países centrais, usualmente transnacionais com grande poderio econômico, poderão marcar a sua supremacia sobre as empresas pertencentes aos países em desenvolvimento que, como apontou SINGH, muitas vezes não possuem condições de competir em tai mercados.

Já se afirmou algumas vezes que hoje o intercâmbio internacional é dominado por grandes corporações, que atuam em várias partes do globo. A despeito do esforço das teorias da globalização em afirmar que tais grupamentos são "mundiais" e, nesse sentido, que não pertencem a nenhum país em particular, é fato que frequentemente suas sedes se encontram em países tidos como desenvolvidos, que não se cansam de demonstrar seu apoio à atividade desses agentes quando se faz necessário (nesse passo, consultar a ajuda do governo norte-americano a suas indústrias durante o período de crise que se instalou entre os anos de 2008 e 2009). Um outro importante fator a ser levado em consideração é a influência políticas que esses grandes empreendimentos possuem sobre os governos locais. Sendo detentoras de grande poderio econômico, responsáveis pelo emprego de milhares de trabalhadores e pelo pagamento de grandes somas de impostos, não é de se estranhar que suas "opiniões" contem com considerável prestígio quando da tomada de decisões que as $\operatorname{afetam}^{205}$.

204 Competition Policy, development and developing countries, cit.

205 "O que existe, isso sim, é uma possibilidade maior de influência da macro empresa nas decisões governamentais, inclusive, muitas vezes, pela troca de recursos humanos de alto nível entre ambas e pelas informações de que depende fortemente o governo em relação às organizações mais importantes do setor 
Dessa constatação tiramos uma grande lição: a competição no âmbito internacional continua a ocorrer entre países - ela não ocorre unicamente entre empresas apátridas, como se quer apregoar. Os motivos para tanto parecem óbvios. Países detentores de empresas fortes, capazes de gerar lucro, dividendos e inovações tecnológicas beneficiam e trazem riquezas a seus países de origem. A oferta de mão-de-obra barata no sudoeste asiático pode ter alterado a localização das fábricas dessas empresas, instaladas em locais nos quais podem se aproveitar dos benefícios trabalhistas. A riqueza por elas gerada, no entanto, continua a levar prosperidade para as suas sedes ${ }^{206}$.

É preciso que se tenha em mente que a competição das empresas brasileira no mercado internacional se dará com esses conglomerados, e não em um mercado pulverizado, formado por pequenas empresas, como nos ensina o ideal de competição da Escola Neoclássica. Ao pensar na conveniência da utilização dos cartéis de exportação, portanto, devemos ter em vista um cenário real, e não um elaborado nos escritórios de teóricos de séculos passados.

Com base nos pensamentos de AJIT SINGH podemos pensar nos seguintes pontos de reflexão sobre a atuação das grandes empresas nacionais: elas são usualmente as responsáveis pelos investimentos em pesquisa e desenvolvimento, incorporação de novas tecnologias, enfim, por boa parte do progresso industrial dos países. Mas esses benefícios trazidos por elas podem acabar, tendo em vista 3 fatores: i) a limitação do auxílio estatal a sua atividade, em atenção às normas internacionais de competição; ii) pelo aumento de tamanho e de poder das empresas internacionais, que acabam por tornar a competição internacional impraticável; e iii) pelo aumento das barreiras de entrada nos mercados externos $^{207}$. Os cartéis de exportação podem ser fatores a mitigar os riscos que ora apresentamos.

privado para a condução de suas política". (FABIO NUSDEO, Fundamentos para uma codificação do Direito Econômico, cit., p. 21).

\footnotetext{
206 "Na sua forma mais desenvolvida - a da globalização dos dias atuais - o capitalismo não tem como unidades econômicas constitutivas apenas as empresas que operam em nível internacional, mas também, se não principalmente, os Estados-Nação ou Estados nacionais. Não são apenas as empresas que competem em nível mundial nos mercados, como pretendem a teoria econômica tradicional: os Estados-Nação são também competidores fundamentais" (LUIZ CARLOS BRESSER-PEREIRA, O novo desenvolvimentismo e a ortodoxia convencional, cit. p. 10).
} 


\subsection{Uma conclusão preliminar}

Diante de todas essas ponderações, é de se perguntar se realmente seria do interesse dos países em desenvolvimento abrir mão da possibilidade de manejo de seus leis concorrenciais e de seu comércio internacional para se adequar a uma política que sequer é compartilhada por todos os países do globo. Nesse passo, a observação de HA-JOON CHANG: "A importância do comércio internacional para o desenvolvimento econômico deve ser enfatizada. Mas o livre-comércio não é o melhor caminho para o desenvolvimento econômico. O comércio ajuda o desenvolvimento econômico apenas quando o país emprega uma mistura de proteção e comércio aberto, ajustando-se constantemente de acordo com as suas necessidades de mudanças e novas aptidões. O comércio é simplesmente muito importante para o desenvolvimento econômico para ser deixado por conta dos economistas do livre-comércio",208.

Mesmo porque, como nos demonstra a história recente, os países asiáticos, que pouca ou nenhuma atenção conferiram à agenda de desenvolvimento proposta pelos economistas neoclássicos, são hoje modelos de desenvolvimento, conforme nos atesta LUIZ CARLOS BRESSER-PEREIRA: “A ortodoxia convencional que parecia irresistível nos anos 1990, quando a hegemonia ideológica americana chegou ao zênite em seguida ao colapso da União Soviética, revelou-se nos últimos anos cada vez mais precária. A globalização que era a bandeira dos países ricos, vai aos poucos se transformando em uma ameaça para eles na medida em que os países que vêm alcançando maior êxito na competição internacional são exatamente aqueles não seguem as recomendações associadas ao globalismo e ao consenso de Washington [...],209.

É preciso que se diga, por muito importante, que a decisão sobre a forma de enfrentar o comércio internacional deve ser uma resolução interna, tomada pelas autoridades nacionais tendo em vista as disposições legais e institucionais do país, os interesses nacionais e o momento histórico que atravessa. Decisões desse porte não podem

\footnotetext{
208 Op. cit., p. 80. Ou ainda nas de FABIO KONDER COMPARATO: "A sociedade brasileira não pode continuar confiando à 'mão muito invisível' dos interesses particulares a realização do desenvolvimento nacional. Esse objetivo maior, ao contrário, deve ser atribuição legal dos centros de poder, organizados e consentidos de acordo com os ditames constitucionais". Muda Brasil, Uma constituição para o desenvolvimento democrático, São Paulo, Editora Brasiliense, 1986, p. 55.

209 LUIZ CARLOS BRESSER-PEREIRA, Desenvolvimento econômico e revolução capitalista, cit., p. 16.
} 
ser tomadas por um técnico estrangeiro, alheio às necessidades, à realidade e aos anseios do Estado. O mesmo deve ser dito com relação ao julgamento de práticas consideradas potencialmente anticoncorrenciais. Como se observou, elas podem ter sido tomadas dentro de escopo maior, que justificaria a sua não submissão a qualquer tribunal internacional que aplicará o direito sem qualquer consideração com relação às políticas internas dos países.

O que se coloca, portanto, é que, independentemente da adoção de uma "política internacional da concorrência”, ou de uma aproximação cada vez maior na forma como as legislações antitruste são redigidas e interpretadas, os cartéis de exportação podem permanecer a disposição dos países para que utilizem o instituto caso considerem conveniente. Isso porque, a despeito dos malefícios apontados, acreditamos que, no cômputo geral, a sua capacidade de fomentar as exportações e de inserir outros players com capacidade de concorrer no âmbito internacional leva os seus benefícios a serem teoricamente superiores aos malefícios ${ }^{210}$.

Obviamente, o posicionamento ora adotado não é contrário à cooperação entre as nações e à busca de maior proximidade entre as legislações antitruste, no que isso não for contrário à independência na tomada de decisões relativas ao desenvolvimento dos países $^{211}$.

Nas palavras de GILBERTO BERCOVICI: “A tentativa de elaborar uma política nacional de desenvolvimento exige a presença ativa e coordenadora do Estado nacional, portanto, desapareceu das considerações governamentais com o liberalismo. A opção do Brasil não é se integrar na globalização ou se isolar de modo autárquico. A questão fundamental é se a integração dar-se-á a partir dos objetivos nacionais ou não. Diante dos desafios e ameaças trazidos pela globalização, precisamos e de um projeto para o Brasil

\footnotetext{
$210 \quad$ "Therefore, it is difficult to say with any great certainty whether export cartels are a problem and how serious a problem they are. [...] Export cartels may create a negative externality. Though they have no cost in their home jurisdictions, they may have a cost globally. Just as in other regulatory fields with externalities (for example, environmental, banking, and securities regulation), negative spillovers limit global welfare even if a particular country were to gain from the externality" (DANIEL SOKOL, op. cit., p. 2).

211 “A existência de competição global não impede, portanto, que os Estados-nação cooperem, principalmente através das Nações Unidas na formulação de regras da competição internacional, como também não impede que objetivos universais de paz e respeito pelos direitos humanos e ambientais sejam buscados. Entretanto, por ocasião do fechamento das negociações da Rodada do Uruguai ao nível da Organização Mundial do Comércio, as regras definidas limitaram o espaço de políticas dos países em desenvolvimento" (LUIZ CARLOS BRESSER-PEREIRA, Desenvolvimento econômico e revolução capitalista, cit., p. 20).
} 
que sirva de substrato material para o desenvolvimento social, político e econômico. Um projeto nacional de desenvolvimento que, no nosso entender, tem seus fundamentos previstos na Constituição de 1988, pressuposto essencial para a retomada dessa discussão" ${ }^{, 212}$.

Como conclusões desta parte do estudo, podemos afirmar que: i) não é possível a aplicação isolada do direito antitruste, visto que estas devem necessariamente ser harmonizadas com tantas outras políticas publicas implementadas pelo Estado; ii) não é possível pensar na adoção da "política internacional da concorrência", pelo menos nos termos em que hoje está desenhada.

\subsection{Contraponto: a discussão ocorre há muito no Brasil}

O objetivo desse ponto de nosso estudo é demonstrar como as discussões sobre comércio internacional e intervenção do Estado na economia não são novas, estando os nossos estudiosos há muito cientes da importância dessas discussões.

Nesse passo, a Comissão Econômica para a América Latina - CEPAL foi criada no âmbito dos Conselhos Sociais e Econômicos da Organização das Nações Unidas - ONU no período do pós-guerra, em 1948, para apoiar o desenvolvimento econômico e social latinoamericano. É uma das cinco comissões regionais com o intuito de realizar estudos e promover o desenvolvimento regional, por meio da difusão de informações, assessoria a governos, projetos de cooperação técnica, entre outras atividades similares. ${ }^{213}$

Em seus primeiros anos, a Comissão Econômica para a América Latina - CEPAL teve como o seu principal pensador o economista argentino RAÚL PREBISCH, Secretário no período de 1950 a 1963 . Foi ele um dos idealizadores da denominada industrialização por substituição das importações, que pretendia subverter a deterioração contínua das taxas de câmbio das economias periféricas, em razão de a demanda por produtos industrializados crescer mas rapidamente que a demanda por matérias primas . Seus estudos, já na década de 1950 indicavam a mencionada deterioração dos termos de troca entre os países. A saída

\footnotetext{
212 MARIA PAUlA DALlari BUCCI, (org.) Políticas Públicas, cit., p. 161.

213 Conforme informações constantes de seu site oficial http://www.eclac.org, consulta em 28 dez. 09.
} 
encontrada para redução do problema foi exatamente a atuação mais firme do Estado, com a construção e o fortalecimento dos parques industriais, que trariam produtos de maior valor agregado para a balança de comércio dos países subdesenvolvidos ${ }^{214-215}$.

No Brasil, o grande nome foi o do economista Celso Furtado, tradutor de artigos de Prebisch para o português e ele próprio autor de importantes textos para a compreensão do desenvolvimento econômico latino-americano, dentre estes sua obra mais importante, "A formação econômica do Brasil", com lugar de destaque no pensamento cepalino. Em seu bojo, o livro traz a ideia de que a evolução histórica dos países em desenvolvimento é distinta da evolução dos países desenvolvidos, e, portanto, suas estruturas econômicas e os problemas que lhes eram correlatos possuíam natureza distinta, demandando, naturalmente, solução distinta.

Desde o início de suas atividades, a Comissão Econômica para a América Latina CEPAL ficou notabilizada pela tentativa de superar o pensamento liberal clássico adotado pela academia no pós-guerra, que, como vimos, não enxergava as diferenças na formação econômica entre os países desenvolvidos e aqueles em desenvolvimento, aplicando a todos as mesmas fórmulas para solucionar problemas distintos. Na prática, reproduzia-se o pensamento ricardiano de divisão e especialização do trabalho, incumbindo aos países desenvolvidos a produção de máquinas e produtos industrializados, e, aos países periféricos, a produção de bens primários, voltados à exportação para servir de matéria prima à produção dos países industrializados ${ }^{216}$. A busca pela superação deste modelo

214 "[...] foi sendo gestada nas oficinas da CEPAL uma concepção inovadora do estado keynesiano, adequadas às economias de capitalismo retardatário. Se mesmo os países avançados não poderiam ser deixados ao sabor das forças do mercado, com mais razão cabia aos Estados periféricos assumir as rédeas do chamado processo de desenvolvimento" (GUIDO MANTEGA, 'A Fantasia Organizada': uma crônica intervencionista, In Revista de Economia Política, v. 6, n. 1, jan.-abril/1986, p. 143).

$215 \quad$ Nas próprias palavras de Celso Furtado: “O problema que mais preocupava a época, e que não podia ser eludido, era o das relações entre industrialização e o comércio exterior. Kybal se sentia aí como pisando em ovos. A doutrina prevalecente nos meios 'responsáveis' rezava que a industrialização latino-americana fora em grande parte fruto das condições artificiais criadas pela guerra. Teria havido 'desvio de fatores' e isso estava repercutindo negativamente na retomada das exportações. Ademais, havia a pressão de grupos ligados ao tradicional import-export alarmados com a 'perda de mercados' que viam na substituição de importações por produção manufatureira local. Mas Kybal estava consciente de que não se podia tomar posição contra a industrialização, pois isso seria colidir com posições manifestas de muitos governos latino-americanos" ( $A$ Fantasia Organizada, Rio de Janeiro, Paz e Terra, 1985, p. 57).

216 “[...] no caso específico da América Latina, é de se verificar que o subcontinente americano, até meados da década de 40, isto é, até o imediato pós-guerra, era constituído por países que, desde o período colonial, baseavam suas relações econômicas de tipo comercial com os países mais avançados (países ditos 'cêntricos') sobretudo através de uns poucos produtos de exportação, tais como minérios e alguns gêneros alimentícios como o café, o trigo, a carne, etc...” (FERNANDO FIGUEIREDO, As transformações do pós- 
primário-exportador foi o norte da Comissão Econômica para a América Latina - CEPAL em seus primeiros anos de trabalho. E a industrialização dos países periféricos foi o caminho encontrado, com o abandono o modelo primário-exportador e a implementação de uma política de substituição das importações.

O período das duas grandes guerras e do entre - guerras, nos quais as atenções dos governos americano e europeus estavam voltadas para a reconstrução de suas próprias economias, possibilitaram o emprego de estratégias que se contrapunham às tradicionais políticas econômicas recomendadas pelos países do centro aos periféricos. O grande diferencial dessas medidas estava na postura ativa do Estado na implementação das políticas que levariam ao desejado desenvolvimento, envolvendo as mais diversas camadas da sociedade na construção do conceito de "nação".

Nas palavras de GUIDO MANTEGA: "Foi nesse cenário de crescente intervencionismo estatal no final da década de 40 que a ONU implantou uma comissão econômica para fazer um diagnóstico da América Latina. A princípio, tratava-se de um empreendimento provisório que deveria funcionar por tempo limitado, à semelhança do que ocorrera com a comissão econômica criada para a Europa no pós-guerra, que ficava a cargo de Gunnar Myrdal, e nem passava pela cabeça dos americanos e ingleses - que controlavam a ONU - a possibilidade dessa comissão vir a consolidar e criar uma teoria econômica antagônica com os princípios liberais do FMI e dos interesses das metrópoles ${ }^{217}$,

Para alcançar este objetivo, a proposta cepalina propunha que o Estado deveria atuar fortemente, por meio da criação da infraestrutura necessária e das indústrias de base, de modo que os empresários capitalistas tivessem as condições necessárias para as demais formas de produção industrial subseqüentes. Nota-se, portanto, o dissenso com o modelo liberal, no qual o Estado ocupa um papel de pouca relevância: no novo modelo o planejamento econômico é o instrumento de ação racional do Estado visando a industrialização, com o fim último de obter desenvolvimento econômico. Nas palavras de Niemeyer Almeida Filho: "Com efeito, a CEPAL contestou abertamente a Lei das

guerra e o pensamento econômico da Cepal, In Revista de Economia Política, v. 10, n. 4 (40), out.dez./1990, p. 138 e ss.). 
Vantagens Comparativas e a inserção internacional das economias latino americanas que, mantidas as condições do imediato pós-guerra, estariam condenadas a uma situação permanente de atraso. A proposição dominante neste campo apontava para uma ação do Estado que quebrasse as barreiras à disseminação do capitalismo, ainda incipiente nos países da América Latina, porém, uma vez que o mesmo se estabelecesse, o crescimento da produção ocorreria mais rapidamente nesses países do que nos países já desenvolvidos, pela operação dos rendimentos crescentes e decrescentes, encurtando o "hiato" entre as condições sociais dos dois grupos de países. A proposta da CEPAL, como sabemos, foi a da industrialização pela ação ativa do Estado. Denotava assim da formulação cepalina que a condição de subdesenvolvimento não era uma condição inalterável, que não pudesse ser modificada pela ação interna, isto é, não havia um determinismo histórico da condição de subdesenvolvimento." $218 \_219$

O pensamento econômico da Comissão Econômica para a América Latina CEPAL obteve grande adesão dos jovens economistas do período. Inspiraram também iniciativas governamentais, como o Grupo Cepal-BNDE, formado por Celso Furtado, Roberto Campos, Maria Conceição Tavares, entre outros, em 1953, cujos trabalhos incluíram estudos e cursos anuais. Além disso, ainda mais abrangente, suas idéias auxiliaram na criação do Plano de Metas do governo de JUSCELINO KUBISTCHEK.

Posteriormente, passado este período, e modificadas as estruturas econômicas de diferentes países, novas concepções de desenvolvimento foram adotadas. RICARDO BIELSCHOWSKY identifica diversas fases da evolução cepalina, em ciclos regulares de cerca de 10 anos. Após o processo de industrialização de 1948 a 1960, os anos 1960 foram marcadas pelas reformas para desobstruir a industrialização, e nos anos 1970 buscou-se a reorientação dos estilos de desenvolvimento; nos anos 1980, o mote era a superação da dívida, e nos anos 1990, a transformação produtiva da América Latina. ${ }^{220}$

\footnotetext{
218 NIEMEYER ALMEIDA FILHO, O desenvolvimento da América Latina na perspectiva da Cepal dos anos 90: correção de rumos ou mudança de concepção?, disponível em http://www.ie.ufrj.br/prebisch/pdfs/12.pdf, acesso em 20 out. 2009.

219 RICARDO BIELSCHOWSKY, Formação Econômica do Brasil: uma obra-prima do estruturalismo cepalino, In Revista de Economia Política, v. 9, n. 4 (38), out./dez. 1990.

220

RICARDO BIELSCHOWSKY (org.), Cinqüenta anos de pensamento da CEPAL. Rio de Janeiro, 2000.
}

Editora Record. 
FERNANDO FIGUEIREIDO resume as linhas mestras do pensamento econômico da CEPAL:

“a) Inconformismo com o ideário neo-clássico 'assexuado', que não estabelecia distinções teóricas no que tange à classificação econômica de países tão díspares como a Inglaterra e a Colômbia, por exemplo;

b) Luta por outra caracterização - através, inclusive, do raciocínio teórico articulado - que distingue entre o 'centro principal' (Europa, Estados Unidos, por exemplo) e os países 'periféricos' (América Latina, por exemplo);

c) Luta por uma postura de superação do atraso entre os dois grupos de países (ou regiões), através de mecanismos que pudessem ser manejados no escopo de governos dos 'países periféricos",221.

Ocorre que os ideais pregados por esses pensadores latino americanos acabaram por se misturar a correntes ideológicas das mais variadas, ocasionando o seu desvirtuamento e, por que não, a sua má aplicação. A partir da década de 1970, os ideais neoliberais e da teoria neoclássica acabaram por se apoderar de muitos formuladores de políticas e passaram a exercer grande influência nas tomadas de decisão desses países ${ }^{222}$. O consenso de Washington, uma das grandes expressões do triunfo do neoliberalismo, passou a ditar as políticas dos países em desenvolvimento, imersos em crises políticas e econômicas.

LUIZ CARLOS BRASSER-PEREIRA afirma que a aplicação generalizada das teorias neoclássicas recomendadas do centro para a periferia acabaram por taxar o movimento desenvolvimentista de retrógrado e ligado a idéias depreciativas como o populismo e a irresponsabilidade econômica ${ }^{223}$.

O ideal de construção de uma teoria econômica voltada especialmente à realidade de cada um dos países parece ter retomado a sua importância no curso da história. Nos últimos anos temos encontrado evidências dessa realidade, seja pela ação mais presente do

\footnotetext{
221 FERNANDO FIGUEIREDO, op. cit., p. 141.

222 Segundo LUIZ CARLOS BRESSER-PEREIRA os países que tiveram um passado de exploração colonial nunca conseguiram, apesar da independência, tonarem-se ideologicamente livres.

223 LUIZ CARLOS BRESSER-PEREIRA, O novo desenvolvimentismo e a ortodoxia convencional, cit., p.8.
} 
Estado brasileiro na economia, seja pela presença de empresas e bancos nacionais no fomento da atividade econômica. Nesse momento, cabe-nos reproduzir a indagação de LUIZ CARLOS BRESSER-PEREIRA: "Diante do fracasso das políticas neoliberais recomendadas pelos países ricos para promover a estabilidade macroeconômica e o desenvolvimento, existe, hoje, na América Latina, um claro movimento de rejeição à ortodoxia convencional. Isto significa que os países mais desenvolvidos e com democracias mais sólidas voltarão ao nacional-desenvolvimentismo dos anos 1950, que tanto êxito teve em promover o desenvolvimento, mas afinal sofreu distorções e entrou em crise, ou podemos pensar em um novo desenvolvimentismo ${ }^{224 \%}$.

Coincidência ou não, as "denúncias", realizadas na década de 1950 parecem ser bastante atuais. Muito acertada, nesse sentido, a afirmação de FERNANDO FIGUEIREIDO: "É curioso notar como, nos dias atuais, a postura ativa do Estado, a que nos referimos, vem sendo progressivamente negada e, paradoxalmente, paulatinamente solicitada" 225 .

Hoje, estão em curso reuniões no âmbito do G-24, grupo estabelecido na Conferência das Nações Unidas para o Comércio e Desenvolvimento - UNCTAD com o objetivo de discutir as negociações dos países em desenvolvimento com órgãos como o Fundo Monetário Internacional - FMI e ao Banco Mundial ${ }^{226}$.

\subsection{O embate nos organismos internacionais}

224 LUIZ CARLOS BRESSER-PEREIRA, O novo desenvolvimentismo e a ortodoxia convencional, cit., p. 5.

$225 \quad$ Op. cit., p. 144.

226 "The G-24 Discussion Paper Series is a collection of research papers prepared under the UNCTAD Project of Technical Support to the Intergovernmental Groups of Twenty-four on International Monetary Affairs (G-24). The G-24 was established in 1971 with the view to increasing the analytical capacity and the negotiation strength of the developing countries in discussions and negotiations in the international financial institutions. The G-24 is the only formal developing-country grouping within the IMF and the World Bank. Its meetings are open to all developing countries" (AJIT SINGH, Competition and Competition Policy in Emerging Markets: International and Developmental Dimensions, G-24 Discussions Paper Series, n. 18, Sept. 2002, Center for International Development Harvard University, p. 3). 
Embora não exista uma autoridade internacional em matéria concorrencial, é bastante comum que os pises mantenham discussões sobre esse tema ${ }^{227}$. A Organização Mundial do Comércio - OMC é um dos fóruns nos quais essas contendas são discutidas, pelo fato de exercer um importante papel no controle e regulação do comércio internacional $^{228}$. A falta de qualquer consenso sobre as regras que devem nortear a política concorrencial e de comércio exterior se reflete em inúmeros pronunciamentos, especialmente aqueles realizados no âmbito do WTO Working Group on Trade and Competition Policy ${ }^{229}$.

As opiniões sobre a utilização dos cartéis de exportação dividem-se basicamente em três: i) os países que defendem a sua proibição; ii) a dos que defendem a sua liberalização e iii) a daqueles que acreditam que devam ser liberados unicamente para alguns grupos de Estados.

Daí os discursos produzidos por Tailândia, Índia e China afirmando que, os países em desenvolvimento, por estarem em condições menos favorecidas, deveriam poder valerse de ferramental para auxiliá-los no incremento de sua atividade externa. Por outro lado, países com níveis de desenvolvimento econômico mais expressivos deveriam abster-se de sua utilização em prol dos objetivos de livre comércio $^{230-231}$. A título de exemplo, a

227 OCDE, Obstacles to Trade and Competition, (1993).

228 "The establishment and the enforcement of free world trade is at the core of the GATT/WTO development”. FLORIAN BECKER, op. cit., p. 97.

229 A declaração Ministerial de Singapura previa que seria dada a devida importância ao fator desenvolvimento nas discussões que seriam então travadas. Ao que parece, o intuito não passou de letra morta. "The Declaration of the WTO Ministerial Conference in Singapore in December 1996 stated in paragraph 20: ' ... we also agree to: ... establish a working group to study issues raised by Members relating to the interaction between trade and competition policy, including anticompetitive practices, in order to identify any areas that may merit further consideration in the WTO framework. In the conduct of the work of the working groups[s], we encourage cooperation... to make the best use of available resources and to ensure that the development dimension is taken fully into account... It is clear understood that the future negotiations, if any, regarding multilateral disciplines in these areas, will take place only after explicit consensus decision is taken among WTO Members regarding such negotiations" (AJIT SINGH, Competition Policy, development and developing countries, cit., p. 1).

230 WTO, Communication from Thailand, WT/WGTCP/W/213, 24 Sept. 2002. "Developing countries do not yet have the kind of well-developed safety nets that exist in industrial countries to provide for those displaced by import competition. There is thus a greater need to cushion its impact by suitable industrial restructuring measures of the kind mentioned above, which would also enable developing countries to embrace greater trade liberalization. In this sense, a discriminatory competition policy can be a concomitant to a non-discriminatory trade policy". WTO, Communication from India, WT/WGTCP/W/216, 26 Sept. 2002. "[...] the representative of Hong Kong, China, said that, given the diversity in stages and patterns of economic development among Members, sufficient flexibility must be incorporated in any possible framework to make it workable among all WTO Members. Provisions for exemptions and exceptions would 
comunicação da Tailândia: “(...) with respect to the fourth proposed core principle with regard to special and differential treatment, we believe that developing countries should be allow to: (1) exempt national and international export cartels. This is because most developing countries' exporters or importers are main small scale and may need to bind together to counter the bargaining power of larger buyers or sellers from industrialized countries (...)".

Evidentemente, a idéia não foi acolhida.

Como já se observou no Capítulo 3, atividades tidas como anticoncorrenciais podem ser bastante lucrativas para os países que as adotam. Nesse sentido, dados trazidos por estudo do Banco Mundial demonstram que, no ano de 1997, foram exportados para os países em desenvolvimento 87 bilhões de dólares em bens oriundos de cartéis que fixaram o preço de venda dos produtos ${ }^{232}$.

Os Estados Unidos, em posição coerente com a existência de isenções aos cartéis de exportação em seu ordenamento, tem defendido a possibilidade de eficiências na utilização desse instrumento, deixando clara a necessidade de diferenciação entre os cartéis tradicionais e os de exportação a que já nos referimos: “(...) with regard to the call for prohibition of so-called 'export cartels', he noted that these arrangements typically were conceived as mechanisms for domestic entities that lacked the resources to engage in

provide greater flexibility for WTO Members to achieve other national objectives such as industrial and economic development. If a multilateral framework on competition policy was adopted, it would be difficult to justify why exemptions should be granted to export cartels, at least in the case of most countries. However, under the principle of special and differential treatment, some exemptions of this nature could be given to developing countries" (WTO, Report on the Meeting of 26-27 Sept. 2002. WT/WGTCP/M/19, 15 Nov. 2002).

231 Nesse sentido, AJIT SINGH, Multilateral competition policy and development: a developing county perspective on the European Community Proposals (2003). Disponível em: www.ideaswebsite.org/feathm/aug2003/MCP.pdf e BRENDAN J. SWEENEY: "Developing states, including India, China and Indonesia, cotend that anticompetitive export cartels are a problem, but a problem restricted to industrializes states. According to the developing states, their export cartels - in addiction on being justified in developing terms - normally consist of small firms without market power. Should there be any move to ban export cartels, developing states have indicated that their export cartels should be exempt" (Op. cit., p. 224).

232 Esse valor correspondia a 8,8\% do total de importação dos países mais pobres. Thomas Fritz, The wrong forum: competition policy in the WTO. Disponível em: http://www.blue21.de/PDF/S2B-CompetitionPolicy.pdf. Acesso em: 10 out. 2008. ADITYA BHATTACHARJEA nos traz dados expressivos sobre o cartel do transporte marítimo: "According to one estimate, breaking up these shipping cartels could reduce transport prices by 20 percent on U.S. routs alone, enabling developing countries to save mores than $\$ 2$ billion on their trade with the U.S." (Trade and Competition Policy, Indian council for research on international economic relations, cit., p. 14). 
effective export activity acting individually. As such, they often had procompetitive effects in that they added another player to the relevant markets and might bring innovation or lower prices. Moreover, they were not secret and therefore did not bear the hallmarks of what was traditionally considered to be a hardcore cartel",233-234.

\subsection{Experiência internacional na aplicação dos objetivos antitruste e na utilização dos cartéis de exportação}

Vamos agora verificar a experiência dos outros países na resolução dos dilemas até aqui discutidos. Os principais pontos para os quais se quer chamar a atenção são: i) as formas como os países lidam com a questão dos objetivos do direito concorrencial (discutidas no Capítulo 2); e ii) a utilização dos cartéis de exportação em cada um dos ordenamentos.

Com relação do primeiro ponto de análise, esperamos demonstrar como diferentes legislações, para dar concretude às suas políticas públicas, alteram ao longo do tempo suas legislações concorrenciais. Apesar de possuírem fundamentos comuns (como a busca da proteção ao consumidor), a forma como as legislações são utilizadas difere substancialmente com o passar dos anos, sem que para isso sejam necessárias alterações em seus textos. Essa "modulação", realizada especialmente pela utilização de "termos vagos", permite que a autoridade concorrencial, ao aplicar o direito, confira maior ênfase a determinados objetivos.

233 WTO, Report on the Meeting of 20-21 Feb. 2003. WT/WGTCP/M/21, 26 May 2003.

234 Sobre as soluções propostas para acabar com a polêmica da utilização dos cartéis de exportação, afirma DANIEL SOKOL: "One possible solution is to allow for these issues to be dealt with by 'hard law' international organizations. What makes an institution hard law is its biding effect through state to state level negotiation. Hard law agreements can be enforced through binding adjudications. In the case of antitrust, hard law among existing institutions means an export cartel ban through the WTO. However, the case of export cartels is different from traditional trade disputes that might use the WTO. The fundamental problem in export cartels is one of information rather than one of conduct. Because there is little data available regarding export cartels, a solution must weigh whether there should be a case by case analysis or a categorical one. For such conduct, the political economy of rent seeking suggests that left to themselves, export cartels will not disappear. A categorical ban on export cartel immunities could be imposed. A more gradualist approach offered by Scherer would be to allow each country an export cartel exemption in up to three industries. A full or partial ban is a difficult proposition to undertake. Because export cartels are case specific and some export cartels may have ancillary justifications for their conduct, a general ban on immunities may not optimize global welfare. As with per se rules, a per se ban on export cartel immunities provides a shorthand for how to address categorical conduct. However, per se rules may prohibit behavior that is pro-competitive”. Op. cit., p. 9. 
6.6.1. Estados Unidos ${ }^{235}$

Como já afirmamos, o berço da legislação antitruste foi os Estados Unidos da América, com a promulgação, em 1890, do Sherman Antitrust Act ${ }^{236}$. Esse mesmo documento continua a ditar as linhas mestras do Direito concorrencial americano, apesar das transformações que ocorreram, como se demonstrará abaixo.

O texto legal previa a condenação de qualquer restrição ao comércio, fosse na forma de contrato, de acordo ou de truste. Reprovava ainda a monopolização dos mercados ou de parte deles ${ }^{237}$. Apesar das inúmeras discussões existentes na doutrina, podemos assumir que o documento foi elaborado com vista a liminar o poder exercido pelos grandes conglomerados industriais, especialmente as estradas de ferro, que desempenharam, um papel de grande importância na expansão territorial norte americana no início do século $\mathrm{XIX}^{238}$.

235 "Whether fear of industrial cartels and the railroad's monopoly power over the agricultural sector or the integration of disparate economies into a single common market, the historical underpinnings and the statutory objectives of the competition laws of the U.S. and the EU provide a relevant backdrop against which the current competition problem may be considered". Erik Johansen, op. cit., p. 337.

236 Notável histórico dos acontecimentos que antecederam o Sherman Antitrust Act podem ser encontrados na descrição de AREEDA e KAPLOW, op. cit..

237 "A: Trusts, etc., in restraint of trade illegal; penalty 'Every contract, combination in the form of trust or otherwise, or conspiracy, in restraint of trade or commerce among the several States, or with foreign nations, is declared to be illegal. Every person who shall make any contract or engage in any combination or conspiracy hereby declared to be illegal shall be deemed guilty of a felony, and, on conviction thereof, shall be punished by fine not exceeding $\$ 10,000,000$ if a corporation, or, if any other person, $\$ 350,000$, or by imprisonment not exceeding three years, or by both said punishments, in the discretion of the court.' B: Monopolizing trade a felony; penalty 'Every person who shall monopolize, or attempt to monopolize, or combine or conspire with any other person or persons, to monopolize any part of the trade or commerce among the several States, or with foreign nations, shall be deemed guilty of a felony, and, on conviction thereof, shall be punished by fine not exceeding $\$ 10,000,000$ if a corporation, or, if any other person, $\$ 350,000$, or by imprisonment not exceeding three years, or by both said punishments, in the discretion of the court."

238 Para grande parte dela, a justificativa que levou a House of the Representatives a aprovar unanimemente a lei e o Senado a aprová-lo com apenas um voto contrário, está ligada ao controle do poder exercido pelas estradas de ferro sobre a economia americana (ERIK JOHANSEN, op. cit., p. 338). ROBERT H. BORK entende que os motivos estavam ligados à proteção do bem-estar do consumidor (The antitrust paradox, New York, Basic Books, 1973, p. 61). De qualquer maneira, o entendimento da Suprema Corte de que o Sherman Antitrust Act não se prestava a regular a compra pela American Sugar Refining Company das ações de outras quatro refinarias americanas, tornando-se detentora de $98 \%$ das refinarias americanas, desencadeou uma onda de concentração entre as empresas. Federal Government, 1895, Disponível em http://www.u-s-history.com/pages/h956.html, acesso em 17 out. 2009. 
A opção do legislador de utilizar termos fluidos como "qualquer restrição ao comércio", "tentativa de monopolização", entre outros, forçaram a Suprema Corte Americana a intenso trabalho de interpretação da lei concorrencial. Nesse sentido, no ano de 1897, firmou o precedente de condenação per se (ou seja, sem ponderação entre prejuízos e benefícios) de quaisquer acordos entre agentes para a determinação de preços a serem praticados no mercado. Segundo a decisão, não caberia aos julgadores perquirir sobre a razoabilidade ou não do estabelecimento conjunto dos preços $^{239}$. O estreito entendimento sobre as condenações per se somente foi revisto após 14 anos, com o julgamento do caso Standard Oil, no qual a Suprema Corte reconheceu a necessidade de serem avaliados os benefícios e malefícios da conduta para definir se se tratava ou não de uma conduta ilegal ${ }^{240}$. A famosa condenação do império de Rockefeller ao desmembramento indica uma opção do Estado americano em buscar mercados mais atomizados, no qual a possibilidade de exercício de poder de mercado fosse diminuta, o que se aproximavam do ideal do mercado perfeitamente competitivo. Essa tendência seria confirmada pela edição do Clayton Act, em 1914.

É interessante verificar que, a despeito das decisões das cortes, o Sherman Antitrust Act e o Clayton Act foram temperados ao longo do tempo pelas necessidades econômicas e sociais que se apresentavam. Conforme se verá com maior vagar quando estudarmos a utilização dos cartéis de exportação nos Estados Unidos, durante a Primeira Grande Guerra a aplicação do direito concorrencial foi bastante arrefecida, tendo em vista questões políticas e o quadro econômico que se apresentava à época.

A retomada do vigor das leis antitruste só veio ocorrer na década de 1940, sob a influência dos ensinamentos da Escola Estruturalista de Harvard. Como se observou no Capítulo 2, essa Escola tinha grade preocupação com as estruturas que se formavam no mercado: o objetivo a ser perseguido pelo direito antitruste era a construção de um mercado pulverizado, que protegesse as pequenas e médias empresas. Ainda com esse intuito de impedir a concentração do mercado, o Hart-Scott-Rodino Act instituiu o controle

\footnotetext{
239 Conforme disponível em http://caselaw.lp.findlaw.com/cgibin/getcase.pl? court=us\&vol=166\&invol=290, acesso em 17 out. 2009.

240 Disponível em http://biotech.law.lsu.edu/cases/Antitrust/Standard_Oil_case.htm, acesso em 17 out. 2009.
} 
prévio dos atos de concentração e a sua análise administrativa, em oposição à análise judicial anteriormente realizada ${ }^{241}$.

Para que fosse possível manter a harmonia entre o texto legislativo e as necessidades e políticas americanas, passaram a ser editadas periodicamente as famosas guidelines, textos que refletem o entendimento das autoridades sobre determinado assunto. De sua evolução, especialmente daqueles que tratam dos atos de concentração, percebemos claramente a alteração no viés de aplicação do direito concorrencial, que, com o passar dos anos, deixou de lado o estruturalismo de Harvard para conferir ênfase à busca pela eficiência econômica, característica da Escola de Chicago ${ }^{242}$.

Mas a "troca" do objetivo do direito da concorrência não foi sem razão. Nesse período, correspondente à década de 1970, os Estados Unidos começaram a enfrentar a concorrência de fortes empresas, especialmente japonesas e alemãs, que tinham como característica o fato de serem grandes conglomerados industriais. Assim, foi necessária uma política pública no sentido de permitir que as empresas americanas pudessem crescer (ainda que por meio de atos de concentração e de concentração do mercado nas mãos de poucos agentes) e, por conseqüência, se tornar mais competitivas no cenário internacional. As leis concorrenciais permaneceram as mesmas, mas a interpretação, como é de se perceber, passou a ser diametralmente oposta.

$241 \quad$ "The Hart-Scott-Rodino Act established the federal premerger notification program, which provides the FTC and the Department of Justice with information about large mergers and acquisitions before they occur. The parties to certain proposed transactions must submit premerger notification to the FTC and DOJ. Premerger notification involves completing an HSR Form, also called a 'Notification and Report Form for Certain Mergers and Acquisitions,' with information about each company's business. The parties may not close their deal until the waiting period outlined in the HSR Act has passed, or the government has granted early termination of the waiting period". Disponível em http://www.ftc.gov/bc/hsr/index.shtm, acesso em 10 set. 2008 .

242 “[...] em 1968 as guidelines publicadas pelo Departamento de Justiça afirmava, a importância de que o controle dos atos de concentração fosse exercido de modo a preservar estruturas de mercado competitivas. Afirmava, nesse sentido que: 'A estrutura do mercado é o foco da política de controle das concentrações do Departamento, porque a conduta da empresa num determinado mercado tende a ser controlada pela sua estrutura [...]. Uma estrutura de mercado concentrada, na qual poucas firmas são responsáveis por uma grande parcela das vendas, tende a encorajar outros tipos de conduta, como o uso de métodos de produção ineficientes ou gastos excessivos com promoções [...]. Novas guidelines foram publicadas pelo Departamento em 1982, alterando substancialmente a versão de 1968. De fato, durante os anos transcorridos desde o primeiro documento, a doutrina econômica e o posicionamento das autoridades antitruste alteraram-se muito. Em reação à ênfase dada na década de 60 à proteção das pequenas empresas e à desconcentração do mercado, as guidelines de 1982 expressam a influência de novas teorias econômicas, a partir das quais a política antitruste deve ter como foco principal a eficiência econômica e o bem-estar do consumidor, ao invés de vagos objetivos de caráter político e social. Esses - apontam os adeptos da teoria, podem ser obtidos indiretamente através da busca da eficiência econômica”. ANA MARIA DE OLIVEIRA NUSDEO, op. cit., p. 88 . 
A despeito da enérgica política anteriormente empregada, contrária à concentração do poder de mercado, tornava-se aceitável a existência de estruturas concentradas, desde que sua formação trouxesse eficiências econômicas que as justificassem. Os ideais da Escola de Chicago de melhor alocação de recursos passaram a ser a Bíblia para a aplicação do direito antitruste Americano, e a concentração econômica, antes vista como um óbice ao mercado perfeitamente competitivo, passou a ser tratada como sinal de maior eficiência.

\subsubsection{O caso específico dos cartéis de exportação}

É na Seção 1 do Sherman Antitrust Act que encontramos a proibição genérica às práticas que possam restringir o comércio. A amplitude da proibição estabelecida acabou por atingir não apenas os cartéis tradicionais mas também outros institutos, como os cartéis de exportação, as organizações agrícolas e as associações de classe, que, a princípio, se enquadravam na idéia de restrição ao comércio (veremos que a legislação nacional também disciplina os cartéis clássicos e outros tipos de acordos entre concorrentes de maneira similar). Muitas dúvidas foram lançadas sobre o alcance da legislação concorrencial, trazendo alto grau de insegurança entre os agentes econômicos.

Nesse período, a Primeira Grande Guerra assolava a Europa, destruindo grande parte de seu parque fabril e impedindo que as estruturas industriais européias atendessem às necessidades básicas da população. Os Estados Unidos, que estavam territorialmente distantes dos ataques, aproveitaram-se do vácuo europeu e experimentaram grande crescimento na demanda por seus produtos, diante da praticamente inexistente concorrência externa. Assim, o país desfrutou de um período excelente de comércio, no qual adquiriu expressiva posição.

Com o fim do conflito, havia claro interesse americano em manter a situação de supremacia no comércio internacional. A Europa, por seu turno, iniciava a sua recuperação e passou a impor condições cada vez mais árduas para a compra dos produtos estrangeiros. O governo americano buscou, então, formas de tornar a atividade de exportação mais simples e menos custosa para seus empresários, assim como de dotá-los de maior poder de barganha em face dos compradores europeus. 
Como conseqüência da necessidade de estímulo às exportações, foi instituído, em 1918, o Webb-Pomerene $A c t^{243}$, com um objetivo bem claro: abrir exceção à rigorosa aplicação do Sherman Antitrust Act para que se mantivesse a favorável posição comercial americana adquirida no período da guerra ${ }^{244-245}$.

O modelo de fomento proposto pela legislação tinha como alvo especialmente as empresas de pequeno e médio porte. Adotando uma fórmula de isenção explícita na qual se exigia a notificação, era necessário que as associações se registrassem em até 30 dias na Federal Trade Commission para que fizessem jus ao benefício.

A isenção, contudo, não foi ampla e se restringia unicamente ao comércio de bens a serem exportados dos Estados Unidos, não incluindo o intercâmbio de serviços ${ }^{246-247}$. Outra exigência era que as associações fossem utilizadas apenas para o comércio no âmbito do mercado internacional - ou seja, sob pena de ser aplicada a proibição genérica aos cartéis estabelecida no Sherman Antitrust Act, não poderiam as associações atuar no comércio em território americano ${ }^{248}$. Além disso, o Webb-Pomerene continha a exigência

24315 U.S.C. $\S \S 61-66$.

244 Os motivos para a edição o Webb-Pomerene Act foram sumariados por MARGARET C. LEVENSTEIN e VALERIE Y. SUSLOW: "(1) The inability of the U.S. firms to work together in representing their own interests vis-à-vis powerful foreign cartels, and (2) the high fixed costs of exporting, which would be particularly burdensome to small firms". Op. cit., p. 789.

245 "Export cartels relating to United States exports come under the general prohibition of Section 1 of the Sherman Act which expressly covers restraints in trade '... with foreign nations'. (1) The concept of restraint of trade in the United States law is similarly broad as in Japan. Thus the concerted storage and export of excess products tending to depress domestic prices was held, among practices, to violate Section (1) of the Sherman Act. OECD, op. cit., p. 14.

246 De acordo com a Seção 1 do Webb-Pomerene Act, a isenção estava restrita ao "trade or commerce in goods, wares, or merchandise exported, or in the course of being exported from the United States or any territory thereof, of such goods, wares, or merchandise, or any act in the course of such production, manufacture, or selling for consumption or for resale".

$247 \quad$ "In addition, the following conduct has been found to be beyond the scope of the Webb-Pomerene exemption: 1. agreements with United States non-members; 2. establishment of joint foreign subsidiaries; 3. Joint licensing activities; 4. restriction of the use of member's patents; 5. preventing imports into the United States; 6. denying members the right to withdraw from the export trade association; or forcing former members to export through the association indefinitely; 7. accepting foreign customers or their United States representatives into an export trade association; and 8. bidding on projects financed by United States Government". OECD, op.cit, p. 15.

248 VLADIMIR PAVIC traz informações sobre o comportamento da jurisprudência americana na determinação da aplicação do Webb-Pomerene Act: “(...) in the case of United States v. United States Alkali Export Association, went on to pronunciate that such export cartels may not allocate world-wide markets with international cartels, nor individually engage in the world-wide restrain of trade. Another limitation on the Webb-Pomerene exemption may be found in the Pfizer Case, where the Indian government sued Pfizer and other American pharmaceutical companies under the Section 4 of the Clayton Act, for some restrictive 
de que as atividades da associação não poderiam prejudicar outro empresário americano que não fosse membro do acordo entre concorrentes ${ }^{249}$.

Tal exigência, aparentemente de menor importância, trouxe grandes dificuldades práticas para que as empresas pudessem se beneficiar da isenção. A uma porque a expressão "causar prejuízo a outro competidor americano" é bastante fluida, de difícil comprovação e compreensão. A insegurança sobre a interpretação que seria dada pelas cortes, somada à possibilidade de aplicação do Sherman Antitrust Act como consequiência do descumprimento do Webb-Pomerene Act, acabou por se tornar um desincentivo à sua utilização. A duas porque trouxe a possibilidade de exportadores americanos realizarem seu comércio de forma isolada, independentemente da associação. Isso impedia que um dos maiores benefícios do estabelecimento de acordo entre concorrentes fosse atingido. Com efeito, a despeito da lógica que permeia os cartéis de exportação, a legislação permitia (e de certa forma protegia) a concorrência entre os produtores americanos no mercado estrangeiro.

O Webb-Pomerene Act não alcançou as adesões e os efeitos que dele se esperavam. Daniel T. MURPHY nos informa que entre os idos de 1918 a 1965, foram registradas na Federal Trade Commission apenas 130 associações sob os seus auspícios. Em novembro de 1978 apenas 29 dessas associações eram registradas, e congregavam aproximadamente 300 empresas exportadoras ${ }^{250}$.

business practices in the world-wide marketing of the pharmaceutical products. It seems that the Supreme Court held that if a conduct produces the direct effect on bough the domestic and foreign markets, the US antitrust laws should be applied to the foreign effects as well. However, when the restrictive practices affect only foreign markets, American antitrust laws will not be applicable". Extraterritoriality in the matters of antitrust, Fucecchio (Itália): European Press Academic Publishing, 2001, p. 97.

249 DANIEL T. MURPHY resume as limitações da seguinte forma: "There are three express limitations to the antitrust exemption, each designed to preserve domestic competition. The associations, agreements, and actions covered by the Webb-Pomerene Act must not restrain either trade within the United States or 'the export trade of any domestic competitor of such association'. In addition, such export associations may not take any actions which artificially or intentionally lessen domestic competition" (The Export Trade Association Act of 1981 - a brief analysis, 4 Hastings Int'l \& Comp. L. Rev. 399, p. 401, 1980-1981).

250 A. PAUL VICTOR nos traz dados que suportam essa afirmação: “At their peak, Webb-Pomerene associations accounted for roughly nineteen percent of U.S. exports, but that figure dropped, in 1976, to as low as 1,5 percent. In 1982, the year that the Foreign Trade Antitrust Improvements Act (Foreign Trading Act) and Export Trading Company Act (Export trading Act) were enacted, only thirty-nine registered Webb associations existed, and these were estimated to have accounted for as little as two or three percent of 1982 exports". Op. cit. 
É motivo de indagação o aparente insucesso da política governamental de estímulo às exportações.

Uma das primeiras reclamações está relacionada à imprecisão do texto. Argumentava-se que a legislação não era clara ao estabelecer quais atividades estariam abrangidas pela isenção. Para muitos, a delimitação teria sido feita pela jurisprudência americana no julgamento do caso United States $v$. Minnesota Mining \& Mfg e estaria relacionada à definição das quantidades de produtos a serem oferecidas no mercado e os valores a serem cobrados, entre outros ${ }^{251}$. A incerteza, entretanto, nunca cessou ${ }^{252}$.

Outra explicação encontrada é que as exigências para se ter acesso às isenções eram tão grandes, que muitos exportadores preferiam optar por formas alternativas de aprimorar seus negócios. Com efeito, com o decorrer do tempo, novas obrigações foram sendo impostas aos exportadores que pretendiam se beneficiar do Webb-Pomerene Act.

Uma terceira reclamação residia no fato de o Webb-Pomerene Act isentar apenas a exportação de produtos, e não a exportação conjunta de serviços. Com é sabido, os serviços passaram a ter importância cada vez maior na economia internacional no período posterior à Segunda Grande Guerra, não havendo sentido em que não estivessem protegidos pela legislação de exportação.

Uma quarta reclamação, bastante emblemática, estava na permissão para que órgão notoriamente contrário à existência dos cartéis de exportação pudesse investigar suas atividades. A autorização para que a Federal Trade Commission, órgão responsável pela tutela da concorrência nos Estados Unidos, fosse responsável pelas associações trouxe grande insegurança aos agentes ${ }^{253}$.

251 No caso U.S. x Minnesota Maning \& Mfg Co., 92 F. Supp. 947 (D. Mass 1950), a Corte Americana teria incluído entre as atividades típicas das associações para exportações as seguintes atividades: "exclusive export arrangements for members, refusal of the associations to handle export of nonmembers, fixing of resale prices of foreign distributors or sales quotas, and price fixing arrangements" (FLORIAN BECKER, op. cit., p. 100).

252 "Although the section 2 of the Webb-Pomerene Act excludes certain qualified associations from the Sherman Act scrutiny, the exemption is lost once the actions of the association artificially affect prices or substantially impair domestic competition" (VLADIMIR PAVIC, op. cit., p. 97).

253 Sobre o assunto, A. PAUL VICTOR: "The failure of the Webb Act has been attributed to numerous factors, [...] perhaps most important, the overt hostility of U.S. enforcement officials toward the activities of Webb-Pomerene associations" (Op. cit.) 
DANIEL T. MURPHY nos recorda, ainda, que as Seções 2 e 5 do Webb-Pomerene Act traziam a possibilidade de que as associações para exportação fossem objeto de sanções penais e criminais por efeitos não pretendidos resultantes de sua atividade no comércio $^{254}$. Veja-se que não estamos tratando de responsabilidade penal por efeitos pretendidos da atividade da associação, mas da responsabilização penal por qualquer efeito dela resultante, independentemente de culpa. A insegurança gerada pelo dispositivo perecia ser motivo suficiente para que qualquer agente racional buscasse se desvencilhar de responsabilidade penal objetiva advinda de resultados que muitas vezes estariam fora de seu controle.

Mais uma vez, recordamos os ensinamentos da Nova Economia Institucional para explicar a insegurança no comportamento dos agentes: "Uma transação freqüentemente sujeita as partes envolvidas ao risco de que elementos acordados entre elas não se efetivem. As partes, ademais, não observam esse risco passivamente ${ }^{255 "}$. Podemos afirmar, com certa confiança, que muitas das decisões dos agentes de não se filiarem às associações para exportação certamente foram motivadas pela falta de razoabilidade da responsabilidade penal decorrente do texto do Webb-Pomerene Act.

A baixa adesão das empresas deu fôlego às vozes contrárias à concessão de isenção aos cartéis de exportação, entre elas algumas autoridades antitruste americanas. O maior argumento estava na contradição existente entre os Estados Unidos da América advogarem no sentido de existirem severas leis antitruste no ambiente internacional e, ao mesmo tempo, fomentarem a existência e utilização de instrumentos tidos como anticompetitivos e contrários ao livre comércio internacional.

Apesar das duras críticas, a corrente defensora da isenção não esmoreceu. Ao contrário, sempre lutou para que os termos do Webb-Pomerene Act fossem revisitados para que se alcançasse maior aplicabilidade de seus mecanismos. $\mathrm{O}$ embate persistiu ao longo do tempo. Encontramos no relato de DOUGLAS ROSENTHAL a afirmação de que, na década de 1980, era costume dos presidentes americanos, em seu State of Union Message, afirmarem que a competição seria um dos objetivos centrais da política econômica

$254 \quad$ Op. cit., p. 405.

255 ELIZABETH FARINA ET AL., Competitividade: mercado, estados e organizações, São Paulo, Singular/Fapesp, 1997, p. 71. 
internacional dos Estados Unidos. E, ainda, que a concordância com os princípios do livre mercado seria condição essencial para o bom desenvolvimento da política doméstica dos Estados Unidos ${ }^{256}$.

Por outro lado, contrariamente, se observava forte discussão para a manutenção e aprimoramento dos termos do Webb-Pomerene Act como forma de fomentar as exportações americanas. Após longos debates, foi instituído, em 1982, o Export Trade Association $A c t^{257}$. Dos debates que ocorreram para sua promulgação é possível inferir que o espírito a animar a edição da lei foi o de recuperar a posição americana no comércio internacional, que, como se afirmou, estava deteriorada pelo surgimento no pós-guerra de outras potências comerciais, como o Japão e a Alemanha ${ }^{258}$.

Os comentários do senador HEINZ elucidam quais seriam seus objetivos: "clarify the antitrust provisions applicable to export trade associations and export trading companies and provide a certification procedure which would enable such associations and companies to obtain antitrust preclearance for specified export trade operations" ${ }^{, 259}$.

Analisando o Export Trade Association Act, DANIEL T. MURPHY divide o instrumento em duas partes. A primeira (Título I), conhecida como Export Trading Company Act, destinava-se a fomentar o investimento de grandes agentes econômicos, como os bancos, em associações para exportação. A segunda (Titulo II), conhecida como Export Trade Association Act reconhecia expressamente a isenção concedida pelo governo às associações destinadas à exportação ${ }^{260}$.

256 DOUGLAS ROSENTHAL, op. cit., p. 1191.

257 Export Trading Company Act, 15 U.S.C. $\$ \S ~ 4001-4003,4011-4021$ (2000). Alguns autores entendem que o Foreign Trade Antitrust Improvements Act seria também um instituto para a promoção das exportações. Dada sua pouca utilização, nos ateremos neste estudo à análise do Webb-Pomerene Act e do Export Trade Association Act.

258 De acordo com MARGARET C. LEVENSTEIN e VALERIE Y. SUSLOW, citando Spencer Weber Waller: "Congress antecipated that the ETC would: 1) encourage the formation of well financed integrated general trading companies along the line of Japanese general trading companies ('sogoshosas') to assist United States exporters with the aspects of the exporting process; 2) allow competitors to jointly exploit market power abroad to offset the power of private cartels and foreign government enterprises; and 3) unleash a wave of export activity by small and medium sized firms previously restrained by uncertainty over application of U.S. antitrust laws". Op. cit., p. 790.

259 Apud DANIEL T. MURPHY, op. cit., p. 405.

260 DANIEL T. MURPHY, op. cit., p. 399. O autor nos traz ainda um breve relato dos textos legislativos que culminaram na promulgação do documento de 1981: “The provisions of Title II of S. 864, 
O Export Trade Association Act abria a possibilidade para as empresas que se candidatassem, a um Certificate of Review para as suas atividades de exportação, ainda que estas não correspondessem à parte significativa de seus negócios ${ }^{261}$. Podemos verificar da leitura do texto dois pontos marcantes: o primeiro relacionado à procura pela simplificação das exportações americanas, com o aumento de vantagens competitivas sobre os concorrentes de outros países; o segundo voltado a não mais cometer os erros do WebbPomerene Act, que acabaram por lhes retirar grande parte de sua eficiência.

Assim, logo de início, observamos a preocupação do legislador em estimular a adesão ao novo instrumento, impedindo que o fracasso do Webb-Pomerene Act se repetisse. Criou-se área específica no Departamento de Comércio com a missão de encorajar a formação das associações e controlar suas atividades ${ }^{262}$ - nesse sentido, atividades como a divisão de mercados, preços coordenados e divisão de custos são alardeadas como benefícios da utilização do Export Trade Association Act. Outra importante alteração está relacionada ao controle governamental, que passou a não mais ser exercido pela Federal Trade Commission, como era antigamente, e sim pelo Departamento de Comércio Americano ${ }^{263}$.

O novo sistema previu a solicitação de isenção por parte dos exportadores, a ser examinada pelo Departamento de Justiça, com posterior provocação do Departamento de Comércio, responsável pelo documento de isenção. Entre os requisitos para que as associações possam se candidatar à isenção, temos:

i) que as atividades desempenhadas pelo cartel não reduzam substancialmente a competição ou o comércio de competidores associados ao cartel;

The Export Trade Association Act of 1979, introduced by Senators Bentson, Chafee, Danforth, Javiits, and Mathias on April 4, 1979. After hearings before the Subcommittee on International Finance of the Senate Committee on Banking, Housing, and Urban Affairs, a revised version was introduced on February 26, 1980 as Amendment n. 1674 to S. 2718. Hearings on the revised bill were held in March and April, 1980, and the bill was passed by Senate on Sept. 3, 1980 by vote of 77 to 0. It was not acted on by the House of Representatives".

261 ETC - Guidelines for the issuance of Export Trade Certificates of Review. Disponível em: www.it.doc.gov/td/oetca/guidelines.html. Acesso em: 24 nov. 2008.

262 O próprio Departamento de Comércio mantém "propaganda" sobre os benefícios de utilização do Export Trade Association Act, disponível em: www.it.doc.gov/td/oetca/teamup.html, acesso em: 24 nov. 2008.

263 Isenção quanto ao Federal Trade Commission Act. 
ii) que não decorra do acordo efeito não razoável no mercado interno americano;

iii) não podem ser objeto da isenção os atos que resultem em revenda nos Estados Unidos dos produtos objetos de venda pelo cartel de exportação;

iv) não podem ser objeto da isenção atividades que se relacionem com métodos desleais de competição com outras associações ou atividades;

v) as atividades do cartel devem servir para promover ou preservar as atividades de exportação americanas; e

vi) a atividade do cartel de exportação não pode se limitar ao comércio de licença de patentes, de tecnologia, de marcas e de atividades de know-how.

Outra importante alteração, também ligada a erro contido no antigo texto legislativo, está na completa imunidade conferida às associações tanto no âmbito federal quanto no âmbito estadual, a quaisquer atividades por elas desenvolvidas que tenham sido objeto de prévia aprovação por parte do governo ${ }^{264}$. Com a medida, acabou-se com a insegurança vivida pelos agentes nos termos do Webb-Pomerene Act, pelo qual poderiam ser responsabilizados por prejuízos causados a outro exportador americano e, muito mais grave, teriam responsabilidade penal objetiva por quaisquer efeitos que seus atos, ainda que não queridos, causassem no mercado ${ }^{265}$.

Veja-se que, nos termos do novo instrumento, ainda que a isenção venha a ser cassada pelos órgãos governamentais responsáveis ou pelo Poder Judiciário, penalidades e restrições somente poderão ser aplicadas com relação a atividades futuras dos agentes, não podendo ser objeto de punição aquelas efetuadas de acordo com o documento de autorização que detinham ${ }^{266}$.

\footnotetext{
264 "If a certificate of Review is granted, the holder is insulated from criminal and damage liability under both federal and state antitrust laws for all conduct specified in the Certificate that occurred while it was in effect. In addiction, all of the conduct specified in the certificate is entitled to a rebuttable presumption of legality" (A. PAUL VICTOR, Op. cit.) 
Outra importante alteração foi trazida pelo Foreign Trade Act no ano de 1982, que estabeleceu que o Sherman Antitrust Act se restringiria a atividades que lesassem o mercado interno americano, dando margem à não utilização da ampla jurisdição que antes era estabelecida. Por fim, temos ainda a ampliação da isenção para as atividades relacionadas a serviços, não se limitando mais apenas aos produtos ${ }^{267}$.

Apesar dos benefícios, a doutrina entende que a utilização dos cartéis de exportação continuou a ser restrita. Como principal motivação para tanto, encontramos certa desconfiança por parte dos exportadores, que são obrigados a informar ao governo dados confidenciais de seu negócio para a concessão da isenção, além da insegurança pelo fato de os tribunais americanos não terem se manifestado em nenhum precedente quanto à utilização do Export Trade Association Act.

A despeito disso, muitos acreditam no sucesso do documento, tendo sido ele responsável por importante estímulo às exportações americanas. Com efeito, dados encaminhados por associações de exportadores dão notícia de terem sido as associações criadas sob o manto do Export Trade Association Act responsável pela exportação de 15 bilhões de dólares no ano de 2003, enquanto as associações criadas pelo Webb-Pomerene Act foram responsáveis por outros 4 bilhões de dólares ${ }^{268}$.

Dados disponibilizados pela Federal Trade Commission dão conta de sete associações para exportação registradas no ano de 2005: American Cotton Exporters Association, American Natural Soda Ash Corp., American-European Soda Ash Shipping Association Inc., California Dried Fruit Export Association, Overseas Distribution Solutions L.L.C., Paperboard Export Association of the United States e Phosphate Chemicals Export Association Inc ${ }^{269}$.

\footnotetext{
267 Veja-se que a partir do novo texto qualquer pessoa poderia se candidatar ao título de isenção, inclusive os bancos, que passaram a ser admitidos nas associações para exportação.

$268 \quad$ E continuam: "While some unfamiliar with their operation might question the continued relevance of the Webb-Pomerene and Export Company Acts, suggesting they are rarely used, in point of fact, there are approximately 100 organizations operating under these exemptions to promote U.S. trade. ETC certificate holders alone number over 5,000 U.S. businesses, with the majority of them being small and medium-sized enterprises - the backbone of the U.S. economy". Correspondência encaminhada por associações de exportadores à Antitrust Modernization Commission, no dia 7 de janeiro de 2005.
} 
Ainda sobre as autorizações do governo norte americano para práticas entendidas como anticoncorrenciais, como a criação de cartéis de exportação, SPENCER WEBER WALLER nos apresenta uma série de três episódios nos quais parecer ser clara o estímulo de criação desses instrumentos em outros países "para a resolução de disputas comerciais bilaterais": i) no ano de 1960 o aumento da importação de aço estrangeiro estava ameaçando a indústria interna. O governo americano negociou, então, acordos com os produtores europeus, para que limitassem a sua exportação para os Estados Unidos; ii) em 1980 o governo novamente negociou limites para a entrada de produtos, dessa vez automóveis japoneses, com o Ministry of International Trade and Industry - MITI; e iii) mais recentemente, o governo americano teria feito acordo similar com o governo japonês, que limitaria a quantidade e o preço dos semicondutores importados pelos Estados Unidos $^{270}$.

Independentemente de qualquer discussão, a possibilidade de utilização dos cartéis de exportação nunca foi retirada do ordenamento jurídico americano. As pressões para que isso ocorresse foram expressivas quando das discussões para a criação do NAFTA (North American Free Trade Agreement). MARGARET C. LEVENSTEIN e VALERIE Y. SUSLOW colacionam importante entendimento americano sobre o tema: "No changes in the U.S. antitrust laws, including the Export Trading Company Act of 1982 or the WebbPomerene Act, will be required to implement U.S. obligations under the NAFTA. These laws have contributed to the export competitiveness of U.S. industries and they remain appropriate in context of a free trade area. Nothing in the Agreement requires any NAFTA government to take measures that would adversely affect such associations" 271 .

Reafirmando a importância e a necessidade de manutenção das isenções no ordenamento americano, quando da criação em 2002 da Antitrust Modernization Commission pelo Congresso, foram recebidos inúmeros comentários favoráveis à

$270 \quad$ The ambivalence of United States antitrust policy towards single-country export cartels, $10 \mathrm{Nw}$. J. Int'1 L. \& Bus. 98 1989-1990, p. 99, 107-108.

271 The North American Free Trade Agreement Implementation Act, NAFTA Administrative Action Statement, ch. 15 (B) (Sept. 3, 1993), apud MARGARET C. LEVENSTEIN e VALERIE Y. SUSLOW, The changing international status of export cartel exemptions, 20 Am. U. Int'l L. Rev. 2004-2005, p. 798. 
manutenção do Webb-Pomerene Act e do Export Trade Association Act, provindos especialmente de grupos representativos de associações comerciais e produtores rurais ${ }^{272}$.

\subsubsection{União Européia}

As normas concorrenciais na União Européia estão divididas em dois grandes grupos: o primeiro referente às normas supra-estatais, responsáveis pela tutela da concorrência entre os Estados, e de responsabilidade da União Européia (tratam-se de disposições gerais a tutelar o bom comércio entre seus Estados-membros273); o segundo grupo é o de normas relativas aos casos em que as questões levantadas não envolvem problemas transfronteiriços, dizendo respeito somente à jurisdição interna de cada um dos países.

A primeira legislação concorrencial do continente é a Alemã, datada de 1923. Sua principal característica é a busca pela liberdade econômica dos agentes que, em sua

$272 \quad$ "“Anyone promoting repeal of a validly enacted law bears the burden of demonstrating that the law's costs exceed its benefits' wrote the Joint Export Trade Alliance, which represents agriculture, industrial and service firms that use these laws. 'In this case, critics of the Webb and ETC Acts have not only failed to make a net cost showing; they have failed to identify any costs at all, and indeed there are none', the group said. 'Assertions that the Webb and ETC Acts cause problems for U.S. antitrust diplomacy or other aspects of the U.S. government's outreach effort in the antitrust field are decisively refuted by the evidence', it added". Comentários transcritos no Washington Tariff \& Trade Letter, de 8 de agosto de 2005. No mesmo sentido, correspondência encaminhada por associações de exportadores à Antitrust Modernization Commission, no dia 7 de janeiro de 2005: "These exemptions have been recognized and repeatedly reaffirmed instruments of U.S. trade policy over 80 years and continue to serve as essential vehicles to promote the competitive and successful sale of U.S. products overseas". No mesmo sentido JOHN R. MAGNUS: “( ...) the positive impact on export trade is undeniable. In the United States, the Webb Pomerene Act and the Export Trading Company Act have helped many of the most effective US export industries compete successfully in world markets. Billions of dollars move annually through export associations organized under these laws. An article posted at the Office of Export Trading Company Affairs (OETCA) website estimated that as of 1998, ETC Act users were logging more than $\$ 30$ billion in annual export trade. Moreover, the more than 5,000 forms successfully using this program include many small and medium sized enterprises which individually might not be able to reach any export market, much less some of the more geographically remote emerging markets. The ability to work collectively helps exporters to approach foreign purchasing associations on a more equal footing, and to survive in a world where competitors may benefit from large subsidies, operate in state-controlled economies, and/or be effectively free from antitrust scrutiny in all of the markets where they operate". (Joint Export Trade Provisions in Antitrust Laws: A Supporter's Perspective, cit., 2005).

273 "The competitions laws of the EU are a part of the treaty originally forming the European Economic Community and are, therefore, base on the same general policies; primarily, market integration and consumer welfare" (ERIK JOHANSEN, op. cit., p. 342). Além disso: "In delimiting the tasks of the Community, the drafters of the Treaty of Rome included in the art. 3 (f) [now 3 (g)] of the Treaty that the activities of the Community include establishing the system of the competition that will assure that the internal market is not distorted. The Treaty goes on and by the series of rules lays down the basic principles of the EEC competition, leaving some space for secondary Community legislation to bring the amount of specificity necessary" (VLADIMIR PAVIC, op. cit., p. 100). 
aplicação extremada, chegou até mesmo a incentivar a formação dos cartéis, como se verá abaixo. O florescimento das demais legislações européias somente ocorreu com o final da Segunda Grande Guerra e o advento da reconstrução do continente.

Os antecedentes da legislação da Comunidade Européia encontram-se no Tratado de Paris, instituído em 1951, pela França, Alemanha, Itália, Bélgica, Países Baixos e Luxemburgo. Seu fundamentos básicos eram a proibição à barreiras comerciais ou a práticas restritivas ao comércio entre esses países. Hoje, as regras de concorrência da União Européia estão estabelecidas no Tratado da Comunidade Européia que traz, em seu preâmbulo, a integração econômica e social como um dos objetivos a serem perseguido pelas autoridades de defesa da concorrência na aplicação da lei. Tendo em vista esse claro objetivo, as normas refletem a preocupação de se garantir a integração do continente, a eliminação das barreiras econômicas e a disciplina das práticas que possam impedir ou prejudicar a concorrência entre os Estados membros ${ }^{274}$.

274 “Artigo 101. (ex-artigo 81.o TCE) 1. São incompatíveis com o mercado interno e proibidos todos os acordos entre empresas, todas as decisões de associações de empresas e todas as práticas concertadas que sejam susceptíveis de afectar o comércio entre os Estados-Membros e que tenham por objectivo ou efeito impedir, restringir ou falsear a concorrência no mercado interno, designadamente as que consistam em: a) Fixar, de forma directa ou indirecta, os preços de compra ou de venda, ou quaisquer outras condições de transacção; b) Limitar ou controlar a produção, a distribuição, o desenvolvimento técnico ou os investimentos; c) Repartir os mercados ou as fontes de abastecimento; d) Aplicar, relativamente a parceiros comerciais, condições desiguais no caso de prestações equivalentes colocando-os, por esse facto, em desvantagem na concorrência; e) Subordinar a celebração de contratos à aceitação, por parte dos outros contraentes, de prestações suplementares que, pela sua natureza ou de acordo com os usos comerciais, não têm ligação com o objecto desses contratos. 2. São nulos os acordos ou decisões proibidos pelo presente artigo. 3. As disposições no n. 1 podem, todavia, ser declaradas inaplicáveis: a qualquer acordo, ou categoria de acordos, entre empresas, a qualquer decisão, ou categoria de decisões, de associações de empresas, e a qualquer prática concertada, ou categoria de práticas concertadas, que contribuam para melhorar a produção ou a distribuição dos produtos ou para promover o progresso técnico ou económico, contanto que aos utilizadores se reserve uma parte equitativa do lucro daí resultante, e que: a) Não imponham às empresas em causa quaisquer restrições que não sejam indispensáveis à consecução desses objectivos; b) Nem dêem a essas empresas a possibilidade de eliminar a concorrência relativamente a uma parte substancial dos produtos em causa.

Artigo 102. (ex-artigo 82.o TCE) É incompatível com o mercado interno e proibido, na medida em que tal seja susceptível de afectar o comércio entre os Estados-Membros, o facto de uma ou mais empresas explorarem de forma abusiva uma posição dominante no mercado interno ou uma parte substancial deste. Estas práticas abusivas podem, nomeadamente, consistir em: a) Impor, de forma directa ou indirecta, preços de compra ou de venda ou outras condições de transacção não equitativas; b) Limitar a produção, a distribuição ou o desenvolvimento técnico em prejuízo dos consumidores; c) Aplicar, relativamente a parceiros comerciais, condições desiguais no caso de prestações equivalentes colocando-os, por esse facto, em desvantagem na concorrência; d) Subordinar a celebração de contratos à aceitação, por parte dos outros contraentes, de prestações suplementares que, pela sua natureza ou de acordo com os usos comerciais, não têm ligação com o objecto desses contraltos". Disponível em http://eurlex.europa.eu/LexUriServ/LexUriServ.do?uri=OJ:C:2008:115:0001:01:PT:HTML, acesso em 26 set. 2008. 
Nesse sentido, o artigo $3 .^{\circ}(\mathrm{g})$ do Tratado dispõe que é necessário que o sistema concorrencial assegure uma concorrência não distorcida no mercado. Para que isso possa ser atingido, outras obrigações são estabelecidas no mesmo artigo $3 .^{\circ}$, como a eliminação das tarifas aduaneiras, das cotas de importação, a redução dos obstáculos à livre circulação de produtos, bens e pessoas, o estímulo à criação de políticas comerciais comuns, o estímulo às atividades de pesquisa e desenvolvimento e o incentivo ao fortalecimento da indústria européia.

A legislação concorrencial européia está inserida dentro de uma política maior de integração do continente. Uma das evidências nesse sentido é o fato de sua aplicação poder ser atenuada caso se entenda que a conduta (ainda que potencialmente anticoncorrencial) se coaduna com os fins buscados pela União Européia e com seus objetivos de política econômica e industrial. Um exemplo desse tipo de interação entre políticas concorrenciais e industrial é a proteção textual à pesquisa e ao desenvolvimento.

Essa "tolerância" é um dos fatores a justificar a existência das isenções individuais e em bloco. As isenções individuais, à semelhança das que ocorrem no Brasil, são permissões para que operações ou atividades que teriam o condão de afetar o mercado (ou seja, aquelas que poderiam distorcer o mercado comum) sejam autorizadas. Essa permissão pode ser condicionada a algumas exigências de forma a amoldá-las aos objetivos trazidos pela legislação. As isenções em bloco, que caracterizam o sistema concorrencial europeu, são regulamentos expedidos pela Comissão que estabelecem conjunto de atividades às quais não se aplicam as restrições concorrenciais trazidas no Tratado Europeu (artigo 101). Elas são textualmente excepcionadas por se justificarem à luz do $\S 3 .^{\circ}$ do mesmo artigo. Segundo ANA MARIA NUSDEO, "Dois exemplos ilustrativos de isenção em bloco são a isenção dos acordos de especialização entre pequenas e médias empresas, do início da década de 80, aplicável a acordos envolvendo parcela de mercado em parte da Comunidade não superior a $20 \%$, e a isenção a acordos de pesquisa e desenvolvimento, de 1984. Notese que esse mecanismo tem sido utilizado com moderação pela Comissão, não se podendo afirmar tenha constituído válvula-de-escape para a aplicação de políticas industriais ao arrepio da política concorrencial da Comunidade ${ }^{275, "}$

275 ANA MARIA DE OLIVEIRA NUSDEO, op.cit., p. 102 e 103. 
O controle dos acordos entre os competidores é realizado por meio do controle de estruturas do mercado, e não pela via do controle de condutas ${ }^{276}$. Essa postura, que será mais bem analisada no Capítulo 8, é uma forma mais "amigável” de enfrentar a questão do acordo entre players, uma vez que permite uma análise mais pormenorizada e considerações sobre as potenciais eficiências desse ajuste. Com relação específica aos cartéis de exportação, a União Européia adota sistema de isenções implícitas, na qual a tutela dos atos ocorre unicamente nas hipóteses dos efeitos anticoncorrenciais serem sentidos dentro do mercado comum europeu ou entre o comércio dos Estados-membros ${ }^{277}$. Caso ocorram efeitos do cartel de exportação dentro do território da União Européia, poderão os agentes solicitar uma específica autorização para suas atividades, nos termos do artigo 85 do Tratado. Isso significa, em outros termos, que os cartéis de exportação só passam pela jurisdição da Comunidade Européia caso sua atuação se reflita dentro do mercado comum. Caso contrário, não são objeto de sua análise ${ }^{278}$.

Nesse sentido, VLADIMIR PAVIC: “[...] an agreement directed wholly at the foreign markets will escape scrutiny of the EC competition laws. However, if such export

\footnotetext{
276 “A Europa [...] seguindo a tradição germânica, analisa os acordos de cooperação do tipo cartel como estruturas que devem ser previamente controladas. Note-se, no entanto, que ali levantam-se (sic) sérias dúvidas sobre a eficácia de uma tal disciplina. A prática tem demonstrado ser impossível o controle preventivo de todos os acordos de cooperação e as autoridades têm sido tolerantes com relação a acordos não levados ao conhecimento dos órgãos de concorrência (tanto na Alemanha quando na UE). Utilizam-se, então, de regras que dispõem sobre a aprovação dos referidos acordos como critério para avaliar, posteriormente, a licitude dos comportamentos dos competidores havidos em função do acordo" (CALIXTO SALOMÃO FILHO, Direito concorrencial - as condutas, cit., p. 20).
}

277 Esse é o entendimento de PAULA A. FORGIONI, ao afirmar que "tanto o art. 81, do Tratado CE, quanto o art. 82 colocam um limite geográfico para sua aplicação, de sorte que sua incidência é subordinada à produção de efeitos anticoncorrenciais no mercado comum. Assim, a Comissão entende que apenas as práticas que efetivamente restrinjam a concorrência na Europa são subsumíveis aos referidos dispositivos, aplicando, dessa forma, a 'doutrina dos efeitos"' (Os fundamentos do antitruste cit., p. 504). E segue afirmando: "O Tratado CE versa, somente, sobre os acordos entre empresas que 'sejam susceptíveis de afectar o comércio entre os Estados-membros e que tenham por objetivo ou efeito impedir, restringir ou falsear a concorrência no mercado comum' (art. 81). Da mesma maneira, o art. 82 veda o abuso de posição dominante na medida em que tal prática seja susceptível de afectar o comércio entre os Estados-membros". No mesmo sentido: "(...) implicit exclusion is now the norm in the European Union (EU). Any export cartel formed for the purpose of exporting goods to non-EU member countries is outside the scope of Article 81 of the Treaty of Rome, which deals with competition" (RATNAKAR ADHIKARI, In defence of export cartels. Disponível em: http://www.sawtee.org/uploads/articles/in9july04.php. Acesso em: 15 set. 2008). 
cartel has the repercussions on the Common Market, creating secondary effects, EC competition provisions will be applied"279.

Sobre o problema da extraterritorialidade da aplicação do direito (para definição sobre o tema, consultar item 8), a Comissão Européia, em 1990, manifestou-se pela aplicação da chamada doutrina dos efeitos. No julgamento do caso do cartel de exportação American Soda Ash, a Corte considerou infração ao artigo 85 do Tratado o acordo celebrado por empresas produtoras de carbonato de cálcio, que se uniram sob o manto da American Natural Soda Ash Corporation (ANSAC), para a exportação conjunta de seus produtos para a União Européia. Os fundamentos da decisão estavam nos fatos de que: i) o acordo tinha como objeto ou efeito provável a restrição ao comércio no mercado comum; ii) a ANSAC, enquanto organização para a venda conjunta, deveria ser considerada como instrumento para a eliminação da concorrência entre seus membros; iii) a ANSAC não demonstrou que a sua atuação iria melhorar a distribuição do carbonato de cálcio no mercado comum; iv) a ANSAC não demonstrou como promoveria o progresso econômico no mercado comum; v) não se poderia considerar o acordo promovido pela ANSAC indispensável para a caracterização dos benefícios apontados ${ }^{280}$. É interessante observar que nesse julgamento a condenação do cartel de exportação não foi feita de forma per se, mas considerou as possíveis influências que ele poderia trazer para a União Européia.

SPENCER WEBER WALLER nos ilustra outro caso no qual uma associação Webb-Pomerene americana foi processada na Europa. Trata-se do caso Wood Pulp, no qual a Comissão Européia processou os exportadores americanos por infração aos dispositivos do Tratado de Roma. Ao final do julgamento, a associação americana foi absolvida $^{281}$.

Com relação aos casos envolvendo a participação dos governos na formação dos cartéis de exportação, a União Européia se manifestou no julgado Franco Japanese Ball

\footnotetext{
279 VLADIMIR PAVIC, op. cit., p. 118. No mesmo sentido: ADITYA BHATTACHARJEA, Export cartels, a developing country perspective, cit., p. 8.

280 Decisão da Comissão de 19 de dezembro de 1990, publicada no Official Journal L 152, de 15 de junho de 1991, p. 54-60.

281 The ambivalence of United States antitrust policy towards single-country export cartels, $10 \mathrm{Nw}$. J. Int'l L. \& Bus. 98 1989-1990, p. 106.
} 
Bearings Agreement ${ }^{282}$. Segundo o entendimento firmado, quatro tipos de condutas devem ser diferenciadas e, portanto, diferentemente analisadas: i) atividades praticadas de acordo com acordos comerciais entre a Comunidade Européia e o Japão; ii) atividades praticadas pelas partes japonesas de acordo com políticas impostas pelo governo japonês; iii) atividades resultantes de acordos ou práticas concertadas que apenas foram autorizadas pelas autoridades japonesas de acordo com a sua lei; iv) atividades resultantes unicamente de acordos ou práticas concertadas da qual participam unilateralmente os contratantes japoneses ou prática concertada juntamente com contratantes europeus.

A Corte entendeu que o primeiro e o segundo tipo de condutas não estavam sujeitas ao artigo 85 do Tratado da União Européia. Entretanto, entendeu que condutas a elas relativas estariam sujeitas ao seu regramento. Para as duas últimas hipóteses, entretanto, estabeleceu que a legislação da comunidade européia deveria ser normalmente aplicada.

Como é possível perceber da sucinta descrição ora realizada, a origem da legislação concorrencial européia é diversa daquela verificada nos Estados Unidos: se para a Europa se visava à unificação do continente, nos Estados Unidos ela esteve ligada a um objetivo bastante pontual - restringir o poder adquirido pelos grandes agrupamentos comerciais e industriais e, na atualidade, buscar a eficiência econômica. A marcada diferença na forma de encarar as disposições concorrenciais explica a famosa afirmação de que a concorrência é instrumental no direito europeu e um fim em si no direito americano.

282 Franco Japanese Ball Bearings Agreement, Decisão da Comissão de 29 de novembro de 1974. Official Journal L 343, de 21 de dezembro de 1974, p. 19-26. 


\subsubsection{Alemanha ${ }^{283}$}

O terceiro ordenamento jurídico no qual analisaremos os cartéis de exportação será a Alemanha. Não é difícil imaginar os motivos pelos quais o país foi escolhido. Como é sabido, a Alemanha possui particular história. E aqui, não apenas nos referimos a sua tardia unificação e ao esforço de OTTO VON BISMARK para a constituição do país, mas especialmente ao seu passado relacionado a grandes empresas e conglomerados industriais $^{284}$

Nomes como Bayer, Basf, Hoechst, entre outros, referem-se a impérios industriais que surgiram em período de franco apoio do governo às empresas que pudessem sustentar o crescimento econômico alemão e evitar os perniciosos efeitos das guerras de preços (vide Capítulo 4). Dentro dessa lógica, o direito antitruste exerce importância fundamental como regulador das estruturas do mercado e como controladora das condutas nele perpetradas.

A legislação antitruste alemã data da década de 1920, época em que a Alemanha enfrentava a hiper-inflação. O mote dessas normas estava na liberdade econômica que deveria ser garantida aos players no mercado. Dentro desse espírito, não havia grande apelo na "caça" aos cartéis e na restrição à atividade dos agentes econômicos, sendo apenas exigido o registro dos acordos entre concorrentes nos órgãos governamentais. A

283 ANDRÉ R. FIEBIG sobre as diferenças de aplicação da lei alemã e da lei americana: "Although the formation of the GWB was strongly influenced by American antitrust laws, the application of the law by the FCO differs significantly from the enforcement of the antitrust laws in the United States. In contrast to the United States, where the application of the antitrust laws is influenced to a large degree by the public policy of the current administration, the application of the law in Germany proceeds in a strictly legalistic manner. The FCO is not generally perceived as a political entity". Op. cit., p. 373.

284 "Through the turn of the century as a consequence of the economic crisis in 1873 , the transition from free trade to protective tariff policy (1879), and the subsequent overcapacity, 385 cartels with 12,000 participating companies came into existence of which 350 were legalized by the court of the German Reich in 1905. 5. Popular examples were the Kali-Syndicate founded in 1888 and the Rheinisch-Westfälisches Coal-Syndicate (1893). The prevailing features of industries with high cartelization (for example basic industries, especially cement and coal or steel and iron) were the production of homogeneous goods and high fixed costs. During World War I cartels were used to support the armament industry. In 1926, the highest share of cartels existed in the textile industry (13\%), the iron and steel industry $(15.2 \%)$ and mechanical engineering (9.5\%) (see Dönnebrink 1995, p. 17). In 1923 (period of the Weimar Republic) the neutrality of economic policy towards cartels ended with the passing of the cartel order in 1923, which put cartelization under the command of an antitrust division. Nevertheless, the number of cartels increased further. At the end of the Weimarer Republic between 2,000 and 4,000 cartels existed. In 1933, another cartel order put the cartels under control of economic policy. From now on cartels were used as a means of promoting or prohibiting concentration according to the requirements of economic welfare. During the period of National Socialism almost all companies were forced to cartelize and support the armament industry in preparation for World War II". (JOACHIM SCHWALBACH e ANJA SCHWERK, Stability of German cartels, HumboldtUniversität zu Berlin Wirtschaftswissenschaftliche/Fakultät Institut für Management, abr. 1998, p. 04). 
preocupação com os acordos entre concorrentes somente emergiu com o final da Segunda Grande Guerra e a imposição de uma lei Concorrencial mais restritiva. No âmago dessa legislação estava a preocupação dos Estados Unidos com a atuação dos poderosos conglomerados germânicos no comércio internacional.

O Bundeskartellamt, conhecido como German Federal Cartel Office, é a autoridade antitruste responsável pela análise das situações nas quais a prática do agente possa ter efeitos em mais de um "estado" alemão. Suas decisões, no entanto, podem ser alteradas por decisão do Federal Ministry of Economics.

A atuação desse órgão é especialmente importante para o estudo dos cartéis. Reporta ANDRÉ R. FIEBIG que existem três situações nas quais a intervenção do Federal Ministry of Economics é possível: a primeira na permissão de funcionamento de um cartel que teoricamente não estaria isentado pelas Seções 2 a 7 do Gesetz gegen Wettbewerbsbeschränkungen (conhecido como GWB). A segunda seria de autorização para o funcionamento de um cartel de exportação, nos termos da sessão 6(1) do GWB. A terceira seria a autorização para operações de concentração que tenham sido objeto de restrição pelo German Federal Cartel Office ${ }^{285}$.

A despeito das alterações da legislação alemã e a sua maior conformidade com as demais legislações concorrenciais, ainda encontramos mitigação de seus dispositivos pela decisão do Federal Ministry of Economics. Nesse caso, por meio de uma "válvula de escape" a legislação antitruste pode ser aplicada de forma mais conveniente às políticas públicas estabelecidas pelo Estado.

ULRICH IMMENGA afirma ser possível encontrar três tipos de cartéis no sistema jurídico alemão: i) os cartéis que buscam regular a concorrência das empresas dentro da Alemanha; ii) os cartéis de exportação, que possuem não só efeitos no mercado externo mas também no mercado alemão; e iii) os conhecidos cartéis puros de exportação, com efeitos sentidos unicamente no mercado externo ${ }^{286}$.

285 The German Federal Cartel Office and the application of competition law in reunified Germany, HeinOnline, 14 U. Pa. J. Int'l Bus. L. 373, p. 383, 1993-1994. 
Em conformidade com as demais legislações antitruste do mundo, os cartéis tradicionais são condenados pelo ordenamento alemão, tendo em vista os já estudados efeitos deletérios a que podem dar causa. Com relação aos cartéis de exportação, após as alterações ocorridas em 1999, a isenção explícita, anteriormente em vigor, foi substituída por uma isenção implícita ${ }^{287}$.

A comprovar a real utilização dos cartéis de exportação na Alemanha e a reconhecida importância que as autoridades reputam a eles, ULRICH IMMENGA colaciona preciso texto do Begründung zum Regierungsentwurf: "Many foreign countries have none or no restrictive antitrust legislation. Other countries enacted general exemptions for foreign trade (for instance the Webb-Pomerene Act in the United States). It would be an unreasonable impediment for German exporters if the Act provided stronger obligations for them than for their foreign competitors. In addition, the foreign market is less know to the German exporter than for the local competitors. This situation is often exploited by forcing the German producer to offer their goods below market prices. This causes a cut-throat competition including losses not only for single firms but also for German exchange balance"288.

É preciso notar que a existência da isenção aos cartéis de exportação não impede que a atividade seja regulada pelo Estado alemão. Com efeito, os cartéis mistos de exportação devem ser individualmente autorizados pela autoridade alemã, em atenção à política comercial desenvolvida ${ }^{289}$.

287 "Given the statutory interpretation of the section 98 (2), it is not surprising that the export cartels are excluded from the scope of the GWB by virtue of section 6 (1). [...] The second sentence of the section 98 (2) imposes a requirement of notification as long as participating undertakings have seat in Germany. Once notified, however, export cartels are out of the reach of GWB”. (VLADIMIR PAVIC, op. cit., p. 133).

288 Begründung zum Regierungsentwurf 1952, Bundestags-rucksache 1/3462, at 17.26.

289 "If the export cartel projects effects on the German market as well, effects principle of 98 (2) will override section 6 (1) and its general exemption”. VLADIMIR PAVIC, op. cit., p. 132. 


\subsubsection{Japão}

O último país selecionado para realizamos análise é o Japão. A escolha se deve ao fato de ser grande potência mundial, com características econômicas bastante particulares em relação a outros países.

Assim como a Alemanha, o Japão possui economia eminentemente voltada ao comércio internacional, mas nem sempre foi assim. Durante muitos séculos, caracterizouse pelo isolamento econômico, definitivamente quebrado apenas com o final da Segunda Guerra Mundial.

Durante o período de segregação, o Japão manteve austera política interna para a criação de grandes empresas nacionais, que seriam responsáveis por importantes setores da economia. A política governamental foi responsável pelo surgimento de impérios industriais existentes até os dias de hoje. Quando da abertura econômica japonesa, a comunidade internacional se deparou com um país fortemente industrializado e com tradição de interferência estatal na atuação das empresas. A esse cenário fático devemos somar a própria tradição japonesa, que prega a atuação conjunta, regida pelo consenso - é marcada pela estabilidade e pelo respeito às tradições, como podemos perceber pela característica de longa duração dos empregos e do cultivo dos antigos relacionamentos comerciais, entre outros ${ }^{290}$. No resumo de ANA MARIA NUSDEO: “A política japonesa de então considerava os monopólios e os oligopólios positivos aos setores industriais modernos, já que permitiam as escalas exigidas para produção de ponta. As grandes unidades de produção, assim, eram estimuladas. Com efeito, a livre concorrência não constituía um princípio de base da ordem econômica japonesa de então. Ao contrário, os princípios da livre-iniciativa e da liberdade de contratação - cujo exercício permitia os acordos restritivos, a cartelização e a monopolização - eram protegidos, sem os limites destinados a compatibilizá-los com o princípio da livre concorrência. De fato, o papel da concorrência na economia foi objeto de discussão pelos governos na era Meiji, com a conclusão de que o modelo de mercado concorrencial típico da Inglaterra não era adequado

290 AKINORI UESUGI, op. cit., p. 353 
a um país em desenvolvimento como o Japão. O principal temor dos opositores ao mercado livre era que a concorrência externa destruísse a incipiente economia nacional”291.

As peculiaridades do Japão acabaram por levantar severas críticas da comunidade internacional, especialmente dos Estados Unidos, no sentido de que os expressivos resultados econômicos obtidos no pós-guerra eram resultado de práticas desconformes com os princípios do livre comércio (e não de efetivas vantagens competitivas), que, portanto, deveriam ser abolidas ${ }^{292}$. Não é de se negar que a legislação japonesa é diferenciada, refletindo a sua cultura milenar. O Anti-Monopoly Act de 1947, a despeito de ser uma norma concorrencial, é considerado por muitos como um instrumento de implementação de políticas industriais e comerciais pelo governo japonês ${ }^{293}$.

Na dicção da Organização para a Cooperação e Desenvolvimento Econômico OCDE: "Apart from the efficiency and countervailing Power aspects, under particular circumstances export cartels have been established to serve quite different purposes, especially in Japan, where export cartels are regarded as an integral part of this country's trade policy. As a result, of the rapid growth of her national economy during the post-war period, the international competitiveness of her industries has been substantially strengthened and this brought forth marked gains in certain areas of export trade"294.

Com relação aos cartéis de exportação, ULRICH IMMENGA ${ }^{295}$ nos informa que a Export-Import Transaction Act excetua as denominadas Export Cooperations $^{296}$ da utilização das normas antitruste. A isenção é conferida de formas diversas.

$291 \quad$ Op. cit., p. 113.

292 HIROKO YAMANE, op. cit., 540. O autor ainda afirma que nos anos 1980, na busca por entender os resultados econômicos japoneses, os Estados Unidos insistiam que barreiras ao comércio eram encontradas no modelo japonês.

293 "It is no secret that the Japanese government believes that cartels can sometimes be useful tools of industrial policy". AKINORI UESUGI, op. cit., p. 355.

294 OECD, op. cit., p. 49.

$295 \quad$ ULRICH IMMENGA, op. cit., p. 102.

296 ALEXIS JACQUEMIN nos traz uma explicação diferente para a isenção aos cartéis: "In Japan, however, a rather different justification is given. Export cartels have to satisfy only a very few broad conditions, the most important of which is that the maintenance of competition would be unfair for the import trade of the country of destination or for its export trade, and capable of injuring the foreign partner". ALEXIS JACQUEMIN, TSURUHIKI NAMBU e ISABELLE DEWEZ, op. cit., p. 685. 
Os cartéis de exportação puros são expressamente excetuados da lei antitruste japonesa, devendo ser notificados ao Ministério do Comércio Internacional no período de dez dias após sua criação. Já os cartéis mistos de exportação, por outro lado, devem obter autorização expressa do Ministério do Comércio Internacional. Existem, ainda, isenções expressas às atividades de exportação das quais não advenha proveito econômico.

O Japão, no entanto, estabelece critérios específicos para que possam as empresas desfrutar das isenções. Assim:

i) não poderão as atividades dos cartéis de exportação violar os tratados internacionais dos quais o Japão for signatário. Da mesma forma, não poderão resultar de suas atividades danos aos importadores japoneses;

ii) não poderão as atividades prejudicar o desenvolvimento das atividades de exportação, visto ser esse um dos objetivos da própria existência dos cartéis de exportação;

iii) não poderão as associações para exportação praticar discriminações que não sejam economicamente justificáveis pelos mecanismos do mercado;

iv) ao estabelecerem a sua composição e examinarem a admissão de novos membros, não poderão os cartéis de exportação realizar restrições à inclusão de novo associado;

v) não poderão advir da existência da associação danos às indústrias domésticas nas atividades de pesca, agricultura, pequenas empresas, consumidores em geral, entre outras ${ }^{297}$. Além disso, o governo japonês poderá estabelecer restrições caso as atividades do cartel de exportação sejam consideradas contrárias ao interesse público japonês.

Veja-se que o caso ora estudado permite visualizar claramente a utilização dos cartéis de exportação como instrumentos de implementação da política do governo japonês. O Export-Import Transaction Act traz condições para que o Ministério de Comércio Internacional regule o setor de exportação. Devemos notar que, dado o já comentado histórico intervencionista do governo japonês, o Ministry of Economy, Trade

$297 \quad$ Ulrich Immenga, op. cit., p. 102. 
and Industry (MITI) desempenha importante papel na adequação da atuação das empresas japonesas à política econômica estabelecida, o que certamente não ocorre em grande parte dos países ocidentais ${ }^{298}$.

AKINORI UESUGI ${ }^{299}$, Secretário-Geral da Fair Trade Commission japonesa, nos informa que a política japonesa em relação aos cartéis tem sido alterada, nos últimos anos, pelas chamadas "reformas estruturais Koizumi" "300. O grande problema enfrentado pela economia japonesa seria o fato de as indústrias voltadas à exportação, especialmente a eletrônica e automobilística, que correspondem a apenas $10 \%$ do total da economia, terem de sustentar o restante da sociedade, acomodada em um modelo que não privilegia a competitividade entre as empresas.

O objetivo da Japan Fair Trade Commission - JFTC, dentro dessas reformas, é levar a cultura de concorrência também ao mercado interno, demonstrando às pequenas e médias empresas que atuam no mercado doméstico japonês a importância de uma política da concorrência ${ }^{301}$. Note-se que as reformas não versam especificamente sobre as empresas responsáveis pela exportação, que, por conseqüência, teriam maiores condições de participar dos cartéis de exportação ${ }^{302-303}$.

298 " $[\ldots]$ in order to protect the export cartels it has authorized, and to ensure the 'sound development of export trade' MITI may in certain instances issue an order imposing minimum standards for price, quality, quantity, or design upon members of export cartels, as well as nonmembers. MITI has also advised many export cartels to disband when it felt they were no long serving national objectives". A. PAUL VICTOR, op. cit., p. 576.

299 AKINORI UESUGI, op. cit., p. 350.

300 Segundo o autor, o Primeiro-Ministro Koizumi está criando uma estrutura econômica apropriada para o século XXI, com reformas nas áreas regulatórias, políticas e concorrenciais sob o slogan "no growth without structural reform". Tais políticas não têm sido bem aceitas por muitos, especialmente pelo fato de o aumento de produtividade ser buscado por meio da alteração das políticas concorrenciais japonesas. Para muitos, o modelo japonês, que já funcionou no passado, deveria continuar a ser empregado. AKINORI UESUGI, op. cit.

$301 \quad$ "This is why conferences in local cities are organized by the JFTC to give speeches on such topics as why competition policy needs to be enhanced in order to re-orient the Japanese economy". AKINORI UESUGI, op. cit., p. 352.

302 A política existente no Japão foi em muito aproveitada pela Coréia do Sul. No resumo de ANA MARIA NUSDEO: "A Coréia do Sul foi um país essencialmente agrícola até a década de 60, quando passou a empreender uma política vigorosa de desenvolvimento industrial que lhe permitiu, na metade dos anos 80 , ter uma renda per capita entre as 15 maiores do mundo e oferecer ao comércio internacional produtos industrializados de ponta, concorrendo com os provenientes das nações do primeiro mundo. [...]. Nesse sentido, como os Japoneses, os coreanos tiveram por política exportar, continuamente, produtos mais complexos e de tecnologia mais avançada, ao mesmo tempo em que protegiam seu mercado doméstico da concorrência internacional, através de mecanismos tarifários e não-tarifários e formulavam um planejamento 


\section{LEGISLAÇÃO NACIONAL}

Nos Capítulos precedentes nos ocupamos em demonstrar o mecanismo de funcionamento dos cartéis de exportação e as dificuldades encontradas para a sua adoção, com ênfase nos problemas externos. Agora é chegado o momento de inserir essas reflexões dentro do ordenamento jurídico brasileiro para que possamos, enfim, discutir a viabilidade de sua existência no Brasil. Essa é a função destinada aos Capítulos 7 e 8.

O foco inicial será a Constituição Federal e os dispositivos que tratam dos objetivos da República Federativa do Brasil. Em seguida, passaremos aos artigos 170 e 219, indispensáveis para aqueles que se propõem a análises que envolvam a ordem econômica. Terminado esse breve estudo, passaremos à Lei 8884/94, a lei Antitruste brasileira.

\subsection{Constituição Federal}

Conforme já asseverado, a Constituição Federal é o texto máximo do ordenamento jurídico brasileiro (confrontar Capítulo 2). Todos os atos legislativos e decisões de quaisquer dos poderes devem necessariamente estar em linha com o proposto e determinado em suas disposições, sob pena de inconstitucionalidade.

das atividades econômicas nacionais. [...]". A respeito dos cartéis, prossegue a autora: "No tocante aos cartéis, o art. 19 veda as ações colaborativas entre concorrentes no caso de preços ou outras condições de produção e distribuição quando tiverem por efeito a restrição substancial da concorrência; inclusive, no seu $\S$ 3. ${ }^{\circ}$, as ações não expressamente acordadas, vale dizer, o chamado paralelismo consciente, na atuação dos concorrentes. Entretanto, o mesmo artigo prevê a possibilidade de autorização dos acordos restritivos pela Comissão de Livre Concorrência quando tiverem por finalidade a racionalização da indústria, a superação de situação de depressão, o aumento da competitividade de pequenas e médias empresas e a racionalização dos termos comerciais em benefício dos consumidores”. Op. cit., p. 125 e s..

303 DANIEL GOLDBERG apresenta uma visão bastante contundente sobre a relação entre política antitruste e industrial nesses dois países: "Conclui-se, portanto, que na tradição asiática praticamente não houve convivência entre política antitruste e política industrial. A análise comparada das experiências coreana e japonesa demonstra a interpolação ou dominância de uma ou outra política. Nas décadas de 1960 e 1970, a política da concorrência - se não foi absorvida pela política industrial - foi completamente anulada por ela. Já na década de 1990, a situação se inverteu. Os princípios norteadores da política antitruste devolveram ao mercado a primazia na alocação dos recursos, relegando medidas verticais de organização industrial a um segundo plano. Nesse contexto, a tradição asiática demonstra quão extensa pode ser a área de conflito entre as políticas industrial e da concorrência”. Op. cit., p. 115. 
A Constituição Federal de 1988 foi o ápice de um lento processo de redemocratização, iniciado no final da década de 1970 e começo da de 1980. Após duas décadas de governo militares, as mudanças sociais e econômicas do país tornaram necessárias reformas, e a pressão política tornou-se muito forte no sentido da reobtenção do voto direto, entre outros direitos basilares. Além disso, o documento foi elaborado em um momento de efervescência política, dando azo a toda sorte de aspirações econômica, sociais e políticas, antes frenadas pelo pulso forte do regime não democrático. Apesar da urgência do constituinte em criar um documento político que restabelecesse os direitos de cidadania do povo brasileiro e que trouxesse também as novas modificações sociais, não se pode acusar a Magna Carta de ser incompleta ou inacabada. Pelo contrário, a Assembléia Constituinte de 1987 conseguiu cristalizar uma parte razoável dos anseios populares, tendo estabelecido um grande elenco de direitos e garantias fundamentais ${ }^{304}$.

Uma das características da Constituição Federal de 1988 é o grande número de normas programáticas, de eficácia restrita. Esses dispositivos indicam objetivos a serem alcançados pelos governantes e funcionam como orientações para o legislador na concreção dos ideais ali expostos - são metas a serem atingidas na concretização do Estado social preconizado. Nas palavras de GILBERTO BERCOVICI: “A constituição de 1988, como uma 'constituição dirigente', possui certas características que a diferenciam de outras constituições. Para a Teoria da Constituição Dirigente, a constituição não é só garantia do existente, mas também um programa para o futuro. Ao fornecer linhas de atuação para a política, sem substituí-la, destaca a interdependência entre Estado e sociedade: a constituição dirigente é uma Constituição estatal e social (CANOTILHO, 2001, p. 150153, 166-169, 453-456). No fundo, a concepção de constituição dirigente, para José Joaquim Gomes Canotilho, está ligada à defesa da mudança da realidade pelo direito. O sentido, o objetivo da constituição dirigente é o de dar força e substrato jurídico para a

\footnotetext{
$304 \quad$ FABIO NUSDEO nos relata como foram aqueles momentos de mudança: "O Brasil vive, mais uma vez, um momento constitucional. Momento denso, fervilhante, cheio de desafios. E de incertezas. Estas decorrem, fundamentalmente, dos muitos anos transcorridos à margem da Constituição. Não porque não houvesse propriamente uma Carta Magna a, pelo menos teoricamente, sobrepairar a ordem jurídica do País desde a sua independência. Mas, porque boa parte dos dispositivos dessas várias cartas apenas esparsamente e de maneira muito incongruente foram, de fato, levados a sério pela Nação. Em suma, eles não impregnaram de fato a ordem jurídica brasileira, mostrando-se, pois, discrepantes da realizada social que deveria, em princípio, estruturar". A ordem econômica constitucional no Brasil, Revista de Direito Mercantil, Industrial, Econômio e Financeiro, ano XXVI, n. ${ }^{\circ}$ 65, (12), jan.-mar. 1987.
} 
mudança social. A constituição dirigente é um programa de ação para a alteração da sociedade (CANOTILHO, 2007, p. 455-459)"305.

De outra parte, a Constituição não inovou sobre o modo de produção, mantendo as bases capitalistas. Sob este aspecto, importa ressaltar que a Magna Carta foi expressa em assegurar o direito de propriedade e o direito à livre-iniciativa dos particulares. No campo do direito econômico, ao Estado restou a exploração da atividade econômica na medida em que necessária aos imperativos de segurança nacional ou diante de relevante interesse coletivo, conforme definidos em lei (texto este que jamais foi editado). Ou seja, a Constituição Federal adotou um modelo que privilegia a livre atuação dos agentes no mercado, mas esse modelo não foi adotado de forma absoluta. Em muitos trechos, o constituinte estatui a necessidade de que o modelo de livre mercado seja compatibilizado e relativizado pela busca por ideais como a justiça social, a proteção ao consumidor, o fim das desigualdades regionais e a erradicação da pobreza ${ }^{306}$.

A convivência entre dispositivos tão diversos não tem sido pacífica. A influência da Escola Neoclássica, estudada no Capítulo 2, não passou despercebida no campo de aplicação do direito. Dessa maneira, não é raro que se observe o desprezo à aplicação de certos preceitos constitucionais, por não estarem em linha com os dispositivos dessa doutrina, e, por outro lado, a supervalorização de outros.

Nesse compasso, é necessário que retornemos (mais uma vez) aos questionamentos sobre a participação do Estado na economia. A busca pelo Estado mínimo, características das décadas de 1980 e 1990 refletiu no Brasil especialmente por meio das ondas de desregulamentação e privatizações. O alarde com relação à necessidade de adoção dessas medidas foi tamanho que, em muitos momentos, parecia que estávamos diante da única

305 JOSÉ CELSO CARDOSO JR (coord), A constituição brasileira de 1988 revisitada: recuperação histórica e desafios atuais das políticas públicas nas áreas econômica e social, Brasília, IPEA, 2009, p. 273.

306 "Melhor explicando: se a Constituição de 1988 adota, de modo explícito e peremptório, o modelo econômico capitalista, já que assegura como um dos fundamentos do Estado brasileiro a livre-iniciativa (art. $\left.1^{\circ}, \mathrm{IV}\right)$; inclui dentro das garantias individuais o direito de propriedade (art. $5^{\circ}, \mathrm{XXII}$ ) e o direito à herança (art. 5 XXX); impede a utilização de exações tributárias com efeito de confisco (art. 150, IV); protege a livre-concorrência (art. 170, IV); limita a intervenção direta do Estado no domínio econômico (art. 173, caput); estabelece regramento expresso à desapropriação para fins de reforma agrária (art. 184 e $\S \S$ ), conjugando, tudo isso, a um modelo de sistema normativo destinado a efetivar o bem-estar e a justiça sociais, resta claro, claríssimo, que a ideologia a ser impressa ao planejamento econômico deve levar em conta a ponderação de interesses consumada pelo constituinte originário, o que equivale a dizer, noutros termos: o modelo econômico é, indiscutivelmente, de natureza capitalista, mas tal opção não repugna adotar medidas tendentes à concretização dos direitos sociais" (MANOEL JORGE E SILVA NETO, op. cit., p. 57). 
alternativa viável para nossa economia - qualquer alternativa que lhe fosse contrária estaria eivada de irresponsabilidade e de resquícios de um populismo inadequado.

Passados alguns anos desses acontecimentos, é possível observá-los com maior serenidade. Sem entrarmos no mérito do sucesso ou insucesso do processo de desregulamentação, podemos afirmar, por certo, que as alterações no papel do Estado alardeadas pelos teóricos neoliberais e pelos adeptos da globalização, não são tão absolutas, como se quer fazer crer. Observamos nos Capítulos anteriores como o Estado continua ativo na condução das suas economias, quer para conduzir o processo de desenvolvimento, quer para a implementação de suas políticas públicas ou mesmo para que se evitem os determinismos econômicos. Ou seja, mesmo em países centrais, com altos níveis de desenvolvimento e com processo de industrialização completo, as políticas públicas não são deixadas de lado em nome da aplicação de modelos econômicos.

Como já asseveramos, acreditamos que a ação do Estado é importante no sentido de permitir e construir espaços ainda ausentes nas economias em desenvolvimento. Estimular determinados comportamentos, como a busca pela inovação, a formação de empresas fortes e competitivas, infra estrutura, condições favoráveis ao crescimento é papel do Estado. E aqui, como bem afirma LUIZ CARLOS BRESSER-PEREIRA, "Não se tratava de substituir o mercado pelo Estado, mas de fortalecer o último para que este pudesse criar as condições necessárias para que as empresas, competindo no mercado, investissem e seus empresários inovassem"307.

Essas observações são relevantes, especialmente quando nos deparamos com um país em desenvolvimento, de industrialização tardia, no qual os modismos e a mera aplicação de recomendações estrangeiras parece encantar os legisladores ${ }^{308}$. É necessário

307 O novo desenvolvimentismo e a ortodoxia convencional, cit., p. 6. Sobre a subordinação o Estado ao mercado, GILBERTO BERCOVICI: "A periferia vive em um estado de exceção econômico permanente, contrapondo-se à normalidade do centro. Nos Estados periféricos há o convívio do decisionismo de emergência para salvar os mercados com o funcionamento dos poderes constitucionais, bem como a subordinação do Estado ao mercado, com a adaptação do direito interno às necessidades do capital financeiro, exigindo cada vez mais flexibilidade para reduzir as possibilidades de interferência da soberana popular" ( $O$ estado de exceção econômico e a periferia do capitalismo, cit.).

308 "A resposta a uma teoria tão pretensiosa, que procura reconstruir a realidade somente em função de - certos - objetivos econômicos, deve ser igualmente pretensiosa. Não basta um argumento de direito positivo, que se contente em afirmar que este ou aquele valor econômico não estão previstos no ordenamento brasileiro. Conhecendo-se a produção legislativa brasileira e sua absoluta volubilidade a ondas econômicas e até internacionais, qualquer construção doutrinária em bases exclusivamente de direito positivo parece irremediavelmente pobre. É preciso trazer pressupostos jusfilosóficos alternativos, a justificar exatamente o contrário do que pretende a análise econômica do direito antitruste, isso é, a força e importância dos valores 
discernimento para verificar que, a despeito das teorias econômicas terem trazido um modo inovador de mensurarmos os efeitos de determinada normas jurídica (e aqui estamos nos referindo especialmente à Análise Econômica do Direito, com a sua estrutura de custo/ benefícios, estudada ao longo do Capítulo 2) a Constituição é, ao menos no ordenamento jurídico brasileiro, o texto guia na aplicação de qualquer disciplina.

A sabedoria está em utilizarem tais conhecimentos em benefício dos objetivos traçados pela ordem constitucional brasileira. O que se espera é exatamente que o desenvolvimento dessas teorias seja capaz de nos auxiliar na compreensão da realidade econômica, para que a busca dos fins determinados por nossa Constituição seja realizada de forma mais efetiva.

Nesse sentido, elucidativa a afirmação de PAULA A. FORGIONI: “[...] a AED pode e deve ser aplicada em benefício da implementação de políticas públicas, com o escopo de incrementar o grau de eficácia material do ordenamento jurídico, em especial dos arts. $170,1 .^{\circ}$ e $3 .^{\circ}$ da Constituição do Brasil. [...]. [A]queles que defendem as fogueiras não compreendem que os juristas e os economistas ligados à AED desenvolveram poderoso instrumental que se presta à implementação de políticas públicas consideradas convenientes/oportunas em uma sociedade democrática. Essa Escola pode auxiliar a melhor compreensão da realidade e - indo além - socorrer os operadores do Direito em sua missão de solucionar e de evitar problemas" ${ }^{, 309}$.

É dentro dessa perspectiva (de atendimento ao quanto disposto no texto constitucional) que devemos inserir a análise dos cartéis de exportação no ordenamento brasileiro. Sabemos que a sua utilização pode resultar em estímulos à atividade de exportação e à economia interna. Resta conferir a viabilidade dessa utilização, a ser decidida tendo como base o disposto na Carta Magna e na legislação infraconstitucional que a regula.

jurídicos na explicação e determinação da realidade econômica" (CALIXTO SALOMÃO FILHO, Direito concorrencial - as condutas, cit., p. 15). 


\subsection{Os objetivos da República Federativa do Brasil ${ }^{310}$}

No texto da Constituição Federal de 1988, os objetivos da República estão estabelecidos no artigo $3^{\circ}$ e são assim enumerados: i) construção de uma sociedade livre, justa e solidária $^{311}$; ii) garantia do desenvolvimento nacional; iii) erradicação da pobreza e da marginalização e, por fim, iv) a redução das desigualdades sociais e regionais e a promoção do bem de todos, sem preconceitos de origem, raça, sexo, cor, idade e quaisquer outras formas de discriminação ${ }^{312}$.

O primeiro objetivo a ser analisado será o desenvolvimento nacional. A realidade que ora se apresenta (e que se apresentava ao legislador de 1988) é a de um país com processo de industrialização em curso, com uma considerável parcela da população tendo acesso a recursos tecnológicos e científicos característicos de países centrais. Por outro lado, os indicadores sociais nos evidenciam que muitos ainda vivem abaixo da linha de pobreza e sequer possuem condições sociais e econômicas de lutar por melhorias em sua condição de vida.

O desenvolvimento nacional de que fala a Constituição se insere nesse contexto e envolve uma série de alterações nas estruturas econômicas, sociais e políticas para que o completo desenvolvimento da sociedade possa ser atingido. Ao final, é um processo que traz melhorias significativas para toda a população, quer seja na forma de melhores índices econômicos, redução do grau de marginalidade, melhores indicadores sociais, coesão

$310 \quad$ "O tratamento do tema da ordem econômica reclama, do estudioso do direito, o desenvolvimento de análise não exclusivamente dogmática, porém funcional. Mais ainda, é adequado, também, que tal análise seja empreendida desde uma perspectiva crítica" (EROS ROBERTO GRAU, A ordem econômica, cit., p. 13).

311 Sobre a sociedade justa, afirma ANTONIO DELFIM NETTO: "É claro que a concepção da 'sociedade justa' é um fato histórico e, portanto, modifica-se. É bem possível que a idéia de uma 'sociedade justa' seja apenas um generoso desejo dos homens, criado por um imperativo ético-racional permanentemente em elaboração. Seja o que for uma coisa é certa: ela não será outorgada a uma sociedade concreta por um líder ou partido. Muito menos por um autor de constituições, por mais competente e bem intencionado que seja" (RICARDO BIELSCHIWSKY e CARLOS MUSSI (coord.), Políticas para a retomada do crescimento - reflexões de economistas brasileiros, Brasília, Escritório da CEPAL no Brasil, 2002, p. 83).

312 Sobre o planejamento necessário para a atuação do Estado, GILBERTO BERCOVICI afirma: "desta forma, não existe planejamento 'neutro', pois se trata de uma escolha entre várias possibilidades, escolha guiada por valores políticos e ideológicos, consagrado, no caso brasileiro, pelo texto constitucional. Desta forma, o planejamento, ainda, deve ser compreendido dentro do contexto da legitimação do Estado pela capacidade de realizar objetivos predeterminados (como os fixados no art. $3^{\circ}$ da Constituição de 1988). O fundamento dessa idéia de planejamento é a perseguição de fins que alterem a situação econômica e social vivida naquele momento. É uma atuação do Estado voltada essencialmente para o futuro" (MARIA PAULA DALLARI (org.), Políticas Públicas, cit., p. 145 e 146). 
social, entre outros ${ }^{313}$. Nas palavras de FÁBIO NUSDEO, o desenvolvimento é um caminho, uma passagem de um estado a outro.

Não podemos deixar de notar que uma parte importante do desenvolvimento é atingida por meio de fatores econômicos (ou seja, por meio da disponibilidade de recursos), notadamente por meio do crescimento e desenvolvimento econômico. Como se percebe da discussão travada ao longo do Capítulo 1, o ingresso, a movimentação e a criação de riquezas dentro do território de um país podem ser ferramentas importantes para que se fomente o desenvolvimento nacional, tendo-se em vista o fato de que mais recursos estarão disponíveis para esse fim $^{314}$.

Certamente que o desenvolvimento nacional requer um conceito de eficiência diverso daquele proposto pelo ótimo de Pareto ou pelo critério KALDOR-HIKS (conhecidos como condições de eficiência estática), que, como observado no Capítulo 2, estão relacionados unicamente à melhor alocação de recursos no mercado. Aqui podemos pensar em um conceito de eficiência dinâmica, mais indicado aos países em desenvolvimento, dado que se relaciona com o fomento de alterações estruturais, econômicas e sociais. Certamente que esse conceito de eficiência dinâmica demanda uma atuação positiva do Estado, visto que o "mercado, por sua própria mão" não poderá se incumbir dessa missão ${ }^{315}$.

313 "Bem ou mal, a humanidade passou a se aperceber de que a paz tão duramente conquistada estaria sob permanente ameaça enquanto as formidáveis discrepâncias em níveis de renda e de qualidade de vida entre nações e entre regiões não fossem superadas ou ao menos atenuadas" (FABIO NUSDEO, CALIXTO SALOMÃO FILHO (coord), Regulação e Desenvolvimento, São Paulo, Malheiros, 2002, p. 11).

314

"Esse o conceito de eficiência estática. Era e é um conceito bom e servível. Mas para as economias desenvolvidas. Certamente não suficiente - muito embora possa ser provisoriamente satisfatório - para as subdesenvolvidas. Estas passaram a exigir um segundo conceito de eficiência: o de eficiência dinâmica, cujo sentido é o de levar a uma progressiva ampliação da própria capacidade produtiva de cada país, implicando a também progressiva abertura de postos de trabalho para acolherem os crescentes contingentes populacionais até então ociosos ou disfarçadamente empregados. (FABIO NUSDEO, CALIXTO SALOMÃO FILHO (coord), Regulação e Desenvolvimento, cit., p. 13).

$315 \quad$ "We now turn to the consideration of the case of the semi-industrial countries, many of which are now fairly advanced in industrial development, e.g., Korea, India, Brazil, Mexico. These countries have reasonably strong states with competent government machinery. However, economic theory suggests that, even for these economies, the US and UK types of competition policy may be inappropriate. A very important reason for this conclusion is that the essential focus of competition policy in advanced countries such as the US is the promotion of allocative efficiency and reduced prices for consumers (WTO, 1997). However, from the standpoint of economic development, this perspective is too narrow and static. In order to raise their people's standard of living, a central objective of developing countries must necessarily be the promotion of long term growth of productivity. The pursuit of this objective of dynamics rather than static efficiency requires, among other things, high rates of investment. In a private enterprise economy, this necessitates encouragement of entrepreneurs' propensity to invest. However, the private sector's 'animal 
Voltando para o tema deste estudo, os cartéis de exportação são nada mais do que meios para que se incentivem as exportações de um país. Sua aplicação, portanto, pode levar ao aumento das riquezas disponíveis, à criação de novos postos de trabalho, a uma indústria nacional mais competitiva, enfim, à maior oferta de bens e serviços no mercado, que podem criar um ambiente propício às alterações desejadas. Não há dúvidas de que a atuação isolada dos cartéis de exportação não irá garantir o desenvolvimento econômico, mas, se forem bem empregados e conjugados a outras políticas públicas, podem ser ferramentas úteis na busca pelo desenvolvimento nacional.

O segundo objetivo da República Federativa do Brasil a ser analisado será o da erradicação da pobreza e da marginalização e o da redução das desigualdades sociais e regionais. Como é de se perceber, todos esses objetivos dependem da atuação positiva do Estado no sentido de implementar políticas que visem ao aumento das riquezas e a criação de oportunidades para a população, assim como atitudes que permitam uma melhor distribuição de renda dentro do Estado.

Obviamente, os cartéis de exportação não se prestam a essa função específica, mas se prestam a uma outra de grande importância: o Estado será melhor capacitado para lutar pela erradicação da pobreza e pela redução das desigualdades na medida em que dispuser de recursos e de condições econômicas para tanto. Nesse aspecto, conforme demonstrado acima, a utilização dos cartéis de exportação pode ser bastante útil.

Devemos nos lembrar, nesse compasso, que os benefícios trazidos pelos cartéis de exportação não se resumem ao influxo de divisas originado pelo maior volume de exportação (ou seja, pelo mero ingresso de moeda estrangeira). Há um incentivo de maior importância, que é o estímulo à atividade interna, que se traduz em uma série de alterações benéficas para a economia nacional, como as relativas ao aumento do número de postos de trabalho no mercado, à disponibilidade de recursos para o aprimoramento dos produtos oferecidos, ao pagamento de melhores salários, ao recolhimento de maior volume de impostos, entre outros. Se bem dirigidos por políticas públicas e sociais, os reflexos dessas alterações poderão e deverão ser sentidos também por aquela parcela da população que se encontra marginalizada economicamente, aumentando a possibilidade de redução das desigualdades econômicas que caracterizam o Brasil.

spirit' are likely to be damped if, as a result of competition, profits became too low, even if temporally". AJIT SINGH, Competition Policy, development and developing countries, cit., p. 12. 
Esse ciclo se confunde com o próprio desenvolvimento nacional, estudado linhas acima.

\subsection{Os cartéis de exportação e o artigo 170 da Constituição Federal}

A ordem econômica deve ser entendida como "o conjunto estabelecido pela Constituição e que tem por objetivo fixar parâmetros da atividade econômica, coordenando a atuação dos diversos sujeitos que põem em prática aquela mesma atividade"316. A Constituição brasileira de 1988, seguindo a esteira das Constituições precedentes, trouxe os temas da Constituição Econômica em seu Título VII ${ }^{317-318}$. Seus preceitos estão estabelecidos ao longo dos artigos 170 se seguintes da Constituição Federal ${ }^{319}$. Desde logo,

316 JOÃO BOSCO LEOPOLDINO DA FONSECA, Lei de Proteção da Concorrência - Comentários à Lei Antitruste, Forence, Rio de Janeiro, 1995, p. 86. JOSÉ AFONSO DA SILVA assim a define: "Vale dizer: a Constituição Econômica formal brasileira consubstancia-se na parte da Constituição Federal que contém os direitos que legitimam a atuação dos sujeitos econômicos, o conteúdo e limites desses direitos e a responsabilidade que comporta o exercício da atividade econômica. Comentário Contextual à Constituição, 3 ed., São Paulo, Malheiros, 2007, p. 708. Para estudos mais aprofundados consultar a obra de EROS ROBERTO GRAU, A ordem econômica na Constituição de 1988, especialmente quanto às distinções entre constituição econômica material e formal e sobre a ambigüidade do termo.

317 "Observando-se a evolução da técnica seguida pelos legisladores Constituintes brasileiros para a disposição dos temas da 'Constituição Econômica', verifica-se como regra permanente a adoção de um primeiro artigo com funções de autêntico 'capítulo introdutório de todo o conjunto, pois nele se definem os seus princípios gerais'. Entretanto, como dissemos anteriormente, a Carta de 1988 deu maior relevo à preocupação de uma 'Introdução', praticamente com funções de 'teoria geral' [...]". WASHINGTON PELUSO ALBINO DE SOUZA, A experiência brasileira de Constituição econômica, In Revista Brasileira de Estudos Sociopolíticos, n. 67/68, p. 105, jul. 1988 a jan. 1989.

318 JOSÉ AFONSO DA SILVA nos traz histórico da ordem econômica: "A ordem econômica adquiriu dimensão jurídica a partir do momento em que as constituições passaram a discipliná-la sistematicamente, o que teve início com a Constituição mexicana de 1917. No Brasil, a Constituição de 1934 foi a primeira a consignar princípios e normas sobre a ordem econômica, sob a influência da Constituição alemã de Weimar". (Op. cit., p. 760).

319 Embora na possamos nos esquecer que ao longo do texto constitucional encontramos outros dispositivos relacionados à ordem econômica. Nesse sentido: [...] por constituição econômica há de se entender o conjunto de normas constitucionais que, exclusivamente ou não, regulam fatos que repercutem no modo de ser econômico da sociedade. É a regulação jurídica da Economia no sentido mais amplo que esta afirmativa comporta. Nesse sentido, preceitos outros, atinentes à ordem econômica, encontram-se não apenas no art. 170 e seguintes, mas em diversas passagens do texto constitucional. Exemplificativamente, o objetivo fundamental da República Federativa do Brasil de garantir o desenvolvimento nacional, com a construção de uma sociedade livre, justa e solidária [...]" (LAFAYETE JOSUÉ PETTER, Princípios Constitucionais da Ordem Econômica, São Paulo, Revista dos Tribunais, 2005, p. 164-165). 
deixamos registrado que a análise de seus dispositivos, traz grande debate para a doutrina $^{320}$.

Como já se afirmou, o texto constitucional foi redigido em ambiente de redemocratização do país, com a esperança de um futuro de liberdade política, o que permitiu que inúmeras linhas ideológicas se manifestassem ao longo da assembléia constituinte $^{321}$. As discussões atingiram também os temas da ordem econômica, como nos revela GASTÃO ALVES DE TOLEDO: "Em meio às discussões sobre todos os grandes temas por ela abrangidos, especialmente os de natureza humanística e social, a questão econômica converteu-se, desde logo, em centro das atenções dos parlamentares. Entendida como problema da presença do Estado na economia, veio a ser disciplinada sob condições políticas complexas, acentuadas pelas disparidades de prosicionamentos programáticos ou ideológicos. Esta circunstância contribuiu para a intensidade dos debates, nem sempre lastreados no conhecimento das realidades econômicas ou presididos da devida racionalidade. Assim, a ordem econômica financeira nasceu da multiplicidade de propostas

320 As diversidades são retratadas por CALIXTO SALOMÃO FILHO: "Complicada e há muito discutida é a questão da correta interpretação dos artigos da Constituição referentes à ordem concorrencial. A aparente amplitude e o generalismo dos dispositivos constitucionais, com frequiência, justificam as interpretações mais díspares do texto constitucional”. Direito concorrencial - as condutas cit., p. 106. Ainda no período anterior à Constituição de 1988 FABIO NUSDEO tecia comentários sobre a ordem econômica: "Em outras palavras, entendo que não devam ser fixados objetivos explícitos e taxativos. Também não me parece que se deva estabelecer ou optar por um sistema econômico perfeitamente caracterizado e definido, pronto e acabado. Preferível a Constituição delinear de maneira extremamente ampla alguns princípios e, sobretudo, alguns mecanismos para permitir à sociedade brasileira, a cada momento da sua trajetória histórica, estar em condições de tomar opções racionais e opções legítimas quanto a esses aspectos cruciais. Advogo, pois, que se estabeleçam mecanismos, fórmulas para assegurar a representatividade para as decisões que a sociedade brasileira deverá tomar no curso dos próximos anos ou nas próximas décadas, uma vez que se espera, que a evolução da sociedade brasileira seja extremamente acentuada e rápida nesse próximo futuro. E mais do que isso, que se assegure à sociedade brasileira meios eficazes de controle sobre o seu sistema econômico, sobre essas decisões que forem tomadas, sobre as opções que se formularem. Apenas para exemplificar, parece que se deveria assegurar, p. ex., uma forma de participação dos diversos setores interessados em qualquer medida que o Estado viesse a tomar no campo econômico, pelo menos quanto às decisões mais fundamentais, p. ex., a criação de novas empresas estatais a regulamentação de setores específicos da Economia, etc. Elas deveriam passar pelo crivo extremamente severo, envolvendo a consulta e manifestação de todos os setores interessados: os consumidores, os trabalhadores, os empresários do setor, ou dos setores afins, os técnicos e especialistas na matéria, e assim por diante" (A ordem econômica constitucional no Brasil, cit.).

321 "A coexistência de princípios e valores jurídicos em uma Constituição de base pluralista, como é a brasileira, impõe a necessidade de não ser absolutizado nenhum deles, pois haverão de conviver em sistemática harmonia. A escolha de um princípio ou valor preponderante traz subjacente a necessidade de preservação para os demais, pois o pluralismo de valores é mesmo a tônica de um Estado Democrático. A unidade, num caso concreto, é obtida a partir da devida ponderação, o que implica na inafastável incidência do princípio da hierarquização axiológica, guia e orientador da busca da devida resposta jurídica tópicosistemática” (LAFAYETE JOSUÉ PETTER, op. cit., p. 209 e 210). 
e da diversidade de conceitos, que acabaram por converte-la em um mosaico normativo, cujo entendimento nem sempre é alcançado sem razoável grau de reflexão",322.

Como já afirmamos, da leitura de seu texto, observa-se que o constituinte optou pelo regime capitalista, que deve ser necessariamente temperado pelos demais princípios e objetivos destacados ao longo do texto constitucional, como, por exemplo, o da busca pela justiça social e pelo pleno emprego ${ }^{323}$.

Os parâmetros para a ordem econômica encontram-se em seus fundamentos nomeadamente a valorização do trabalho humano e a livre-iniciativa - no fim por ela buscado - a existência digna de todos - e nos princípios enunciados ao longo do artigo 170 da Constituição ${ }^{324-325}$. A diferença entre esses termos pode ser assim resumida: "Deve-se observar que, sobretudo na análise de normas sobre a ordem econômica, os princípios entendidos enquanto pautas cuja observância corresponde a um imperativo de justiça, de honestidade ou de outra dimensão da moral ou, ainda, porque explicitam as valorações políticas fundamentais do legislador constituinte e estabelecem valores fundamentais de organização social - convivem com outras pautas interpretativas cuja função é semelhante

322 IVES GANDRA DA SILVA MARTINS e FRANCISCO REZEK (coord.), Constituição Federal, Avanços, contribuições e modificações do processo democrático brasileiro, São Paulo, Revista dos Tribunais, 2008, p. 601-606).

323 "Aqui, como no mundo ocidental em geral, a ordem econômica consubstanciada na Constituição não é senão uma forma econômica capitalista, porque ela se apóia inteiramente na apropriação privada dos meios de produção e na iniciativa privada (art. 170). Isso caracteriza o modo de produção capitalista, que não deixa de ser tal por eventual ingerência do Estado na economia, nem por circunstancial exploração direta da atividade econômica pelo Estado e possível monopolização de alguma área econômica (...). A atuação do Estado, assim, não é nada mais nada menos do que uma tentativa de por ordem na vida econômica e social, de arrumar a desordem que provinha do Liberalismo" (JOSÉ AFONSO DA SILVA, Comentário Contextual à Constituição,cit., p. 705).

324 “Artigo 170. A ordem econômica, fundada na valorização do trabalho humano e na livre-iniciativa, tem por fim assegurar a todos existência digna, conforme os ditames da justiça social, observados os seguintes princípios: I - soberania nacional; II - propriedade privada; III - função social da propriedade; IV livre concorrência; V - defesa do consumidor; VI - defesa do meio ambiente, inclusive mediante tratamento diferenciado conforme o impacto ambiental dos produtos e serviços e de seus processos de elaboração e prestação (Redação dada pela Emenda Constitucional n. 42, de 19.12.2003); VII - redução das desigualdades regionais e sociais; VIII - busca do pleno emprego; IX - tratamento favorecido para as empresas de pequeno porte constituídas sob as leis brasileiras e que tenham sua sede e administração no País (Redação dada pela Emenda Constitucional n. 6, de 1995). Parágrafo único. É assegurado a todos o livre exercício de qualquer atividade econômica, independentemente de autorização de órgãos públicos, salvo nos casos previstos em lei."

325 Não adentraremos na profunda discussão entre a diferenciação entre os fundamentos, princípios e fins buscados pela Ordem Econômica. Limitar-nos-emos a expor o quanto afirmando pela doutrina. Para MANOEL GONÇALVES FERREIRA FILHO os fundamentos são os "princípios fundamentais que devem reger a economia em vista da existência digna todos" (Comentários à Constituição Brasileira de 1988, São Paulo, Saraiva, 1995, v. 4). 
à sua no ordenamento. É o caso das diretrizes, que se referem a objetivos a serem atingidos, geralmente em questões econômicas, políticas e sociais. As políticas públicas de alguma forma adotadas pela ordem jurídica constituem diretrizes para orientar a interpretação e a aplicação do Direito" ${ }^{\text {326-327. }}$.

Essas normas incorporam valores e metas estabelecidas pelo constituinte e são necessárias para que o Estado disponha de um nível mínimo de controle sobre as relações econômicas que caracterizam a economia moderna. Aqui, mais uma vez, percebe-se que objetivos e princípios aparentemente contraditórios foram colocados lado ao lado pelo constituinte.

Uma primeira solução para o aparente conflito é tomar como parâmetro a advertência de EROS ROBERTO GRAU de que a Constituição não pode ser interpretada em tiras, em pedaços ${ }^{328}$. Portanto, os princípios, fins e fundamentos da ordem econômica devem ser harmonizados ao quadro estabelecido pela Constituição Federal. Erro seria tentar transformar cada um deles em absolutos, em detrimento dos demais. No mesmo

326 ANA MARIA NUSDEO, op. cit., p. 233. Ainda sobre a questão dos fundamentos e princípios, afirma LAFAYETE JOSUÉ PETTER; "A análise das constituições brasileiras pretéritas dá conta de que determinados valores ora assumem a qualificação de fundamento da ordem econômica, ora consubstanciam um princípio. Para a doutrina especializada, há de se tomar a idéia de fundamento como causa da ordem econômica, ligando-se, portanto, ao próprio objetivo por ela pretendido, enquanto que os princípios serão os elementos pelos quais aquela ordem se efetivará, ou seja, o ponto de partida para esta efetivação, e que portanto, não pode ser relegado. Como adverte Peluso, fundamento, no sentido aristotélico, é tomado como causa no sentido de razão de ser. Já princípio caracteriza o ponto de partida de um processo qualquer. Um exame das constituições brasileiras revela que elas foram dúbias e inseguras na adoção destes elementos, ora situando-os como fundamento, ora como princípios. Como destaca o professor 'um inegável empirismo semântico faz com que os termos fundamentos e princípios, em seu uso jurídico, adquiram um sentido mal definido, sendo por vezes assemelhado" (Op. cit., p. 167).

$327 \quad$ "Sometimes a rule and a principle can play the same role, and the difference between them is almost a matter of form alone. The first section of the Sherman Act states that every contract in restrain of trade shall be void. The Supreme Court had to make the decision whether this provision should be treated as a rule in its own terms (striking down every contract 'which restrain trade', which almost any contract does) or as a principle, providing a reason for striking down a contract in the absence of effective contrary policies. The court construed the provision as a rule, but treated that rule as containing the word 'unreasonable', and as prohibiting only 'unreasonable' restrains of trade. This allowed the provision to function logically as a rule (whenever a court finds that the restraint is 'unreasonable' it is bound to hold the contact invalid) and substantially as a principle (a court must take into account a variety of other principles and policies in determining whether a particular restraint in particular economic circumstance is 'unreasonable'. Words like 'reasonable', 'negligent', 'unjust', and 'significant' often perform just this function. Each of this terms makes the application of the rule which contains it depend to some extent upon principles or policies lying beyond the rule, and in this way makes that rule itself more like a principle" (RONALD DWORKIN, Taking Rights Seriously, Cambridge, Harvard University Press, 1977, p. 27-28).

328 “[...] sustento que, assim como jamais se aplica uma norma jurídica, mas sim o direito, não se interpretam normas constitucionais isoladamente, mas sim a Constituição, no seu todo" (EROS ROBERTO GRAU, op. cit., p. 189). 
sentido, é a afirmação de PAULA A. FORGIONI: “Os princípios veiculados no art. 170 da Constituição do Brasil e todas as regras que a partir deles se desdobram estão à disposição dos fins enunciados pelo art. $3^{\circ}$ da própria Constituição e, portanto, não podem ser lidos ou tomados apartadamente do sistema ao qual pertence e ao qual, ao mesmo tempo, dão conformação, 329 .

A segunda solução é compreender que os termos utilizados pelo legislador são abertos, permitindo análise e interpretação diversas conforme a realidade que se apresenta. É dado ao intérprete, dentro de determinado momento histórico, ajustar a aplicação do texto constitucional conforme as necessidades e o ambiente institucional com o qual se defrontam $^{330}$.

Como se viu, a realidade e vivacidade do dia-a-dia econômico são fatores que influenciam as normas da Constituição Econômica, tornando necessário que sejam harmonizadas ao ambiente social, político e econômico do país. Mais, os termos abertos permitem que os objetivos da Ordem Econômica se adaptem aos objetivos traçados para a República Federativa do Brasil ${ }^{331}$.

$329 \quad$ PAULA A. FORGIONI, Fundamentos do Antitruste, cit., p. 192.

330 “[...] todo sistema constitucional, para ter efetividade sociológica e não apenas vigência jurídica, não pode ser estático e meramente declarativo, como imaginavam os primeiros teóricos do constitucionalismo; ele deve, antes, adaptar-se permanentemente às mutações sociais. Sem duvida, a ordem constitucional de um povo é estabelecida para durar e sobrepairar aos entrechoques políticos e econômicos, que compõem a tessitura da vida em sociedade. Mas isso não significa que uma Constituição de país subdesenvolvido, no limiar do século XXI, possa visar à perenidade. Se ninguém mais aceita, hoje, o simplismo mecanicista de considerar o Direito como mera superestrutura social, totalmente dependente das condições sócio-econômicas que lhe servem de base; se todos acabam reconhecendo, em maior ou menor grau, a relação dialética entre lei e os fatos sociais (pois a própria lei, em certo sentido, faz parte do conjunto dos fatos sociais), a verdade é que a evolução histórica das condições de vida em sociedade acarreta a constante mudança do esquema normativo em vigor. Essa realidade é ainda mais evidente, quando se está diante de uma Constituição, cujo objetivo último é criar condições institucionais para a transformação da sociedade. A própria dinâmica do desenvolvimento nacional, favorecida pelas instituições políticas e econômicas, acaba repercutindo sobre o quadro constitucional". FÁBIO KONDER COMPARATO, Muda Brasil, cit., p. 13.

331 "Utilizando-nos dos estudos e da terminologia proposta pro Eros Roberto Grau, podemos dizer que os princípios gerais do direito são proposições descritivas, através das quais os juristas referem, de maneira sintética, o conteúdo e as grandes tendências do direito positivo. São as normas que embasam o ordenamento jurídico orientando, inclusive, a aplicação das regras. De outra parte, há, ainda, os princípios jurídicos que constituem regras jurídicas, ou seja, as normas explicitamente formuladas no texto do direito positivo. Mas, como diz Canotilho, estes pontos de partida carecem de descodificação. O sistema jurídico é um sistema de regras e princípios, 'pois as normas do sistema tanto podem revelar-se sob a forma de princípios como sob a forma de regras'. Assim, as regras e os princípios são duas espécies de normas. Os princípios jurídicos embasam as regras e lhes são hierarquicamente superiores. Podem, então, 'desempenhar uma função argumentativa, permitindo, por exemplo, denotar a ratio legis de uma disposição (...) ou revelar normas que não são expressas por qualquer enunciado legislativo, possibilitando aos juristas, sobretudo aos juízes, o 
Para verificar a conformidade da utilização dos cartéis de exportação com a Constituição Econômica, escolhemos analisar os seguintes princípios e fundamentos: i) a valorização do trabalho humano; ii) a livre-iniciativa; iii) a soberania nacional; iv) a livre concorrência; v) a redução das desigualdades regionais e sociais; vi) a busca pelo pleno emprego; e vii) o tratamento favorecido para as empresas de pequeno porte constituídas sob as leis brasileiras e que tenham sua sede e administração no País.

\subsubsection{Valorização do trabalho humano}

A valorização do trabalho humano é princípio que está na Ordem Econômica brasileira desde a constituição de 1946. Segundo MANOEL GONÇALVES FERREIRA FILHO, trata-se de uma incorporação à legislação nacional de preceito estabelecido na doutrina social da Igreja, na qual o trabalho tinha relação com a obra criadora de Deus e não deveria ser tratado como mera mercadoria ${ }^{332}$. Por sua importância a valorização do trabalho humano também é considerada um dos fundamentos da República Federativa do Brasil, conforme artigo $1^{\circ}$, IV.

O trabalho é condição necessária para a sobrevivência: por meio dele se adquirem os meios financeiros necessários para que o homem possa conviver em sociedade. É também um fator de produção, a ser considerado dentro da política econômica. JOSÉ AFONSO DA SILVA acredita que é também o ponto central da Ordem Econômica, motivo pelo qual deve ter prioridade sobre todos os outros valores da economia de

desenvolvimento, integração e complementação do direito'. Um exemplo bastante elucidativo da aplicação das regras e dos princípios no sistema antitruste nos é dado por Dworkin. Sustenta esse autor que ao construir a regra da razão, os tribunais norte-americanos acabaram por permitir que o art.1. do Sherman Act funcionasse ao mesmo tempo, como uma regra (rule) e um princípio (principle). O referido dispositivo, como já inúmeras vezes referido nesse trabalho, determina que todo e qualquer contrato, combinado sob a forma de truste ou qualquer outra forma ou conspiração em restrição ao tráfico ou comércio entre os Estados, ou com nações estrangeiras, é ilícito. Ao construir a regra da razão, as cortes americanas, na verdade, determinaram quando esse dispositivo deveria ser tratado como uma regra ou como um princípio. Trata-se da regra quando se determina ilícito qualquer contrato que restrinja a concorrência, aplicando-se, literalmente, o texto normativo. Ao invés, é facultado o tratamento do mesmo dispositivo como princípio, pois, ao introduzir na hipótese normativa a palavra unreasonable, a corte permitiu sua flexibilização. Desse modo, por força do princípio que foi introduzido, conclui Dworkin, a corte deverá levar em consideração uma série de outros princípios e políticas com o escopo de determinar quando uma determinada prática restritiva, em particular contexto, não é 'razoável'”. PAULA A. FORGIONI, Os Fundamentos do Antitruste, cit., p. 309. 
mercado $^{333}$. Nesse sentido, é válida a atuação do Estado para a proteção aos trabalhadores, como ocorre com as normas constitucionais estabelecidas para o seu amparo e na legislação trabalhista. Da contraposição entre o trabalho como fator de produção versus o trabalho como direito constitucionalmente protegido, emergem diversos fatores de instabilidade.

Com relação ao tema deste trabalho, observamos que a utilização dos cartéis de exportação pode elevar os níveis de exportação de um país e ser um agente dinamizador de sua economia. Dentro desse aumento na atividade, pode ocorrer maior demanda por trabalhadores, o que poderia contribuir para a maior oferta de empregos e melhor remuneração da mão-de-obra ${ }^{334}$. Nesse sentido, podem ser considerados um forma de valorização do trabalho humano. As palavras de LAFAYETE JOSUÉ PETTER refletem esse entendimento: “(...) tome-se a noção de que valorizar o trabalho humano diz respeito a todas as situações em que haja mais trabalho, entenda-se, mais postos de trabalho, mais oferta de trabalho, mas também àquelas situações em que haja melhor trabalho, nessa expressão se acomodando todas as alterações fáticas que repercutam positivamente na própria pessoa do trabalhador (e.g., o trabalho exercido com satisfação, com menos riscos, com mais criatividade, com mais liberdade, etc $)^{335 ", ~}$

\subsubsection{Livre-iniciativa}

A livre-iniciativa, segundo MANOEL GONÇALVES FERREIRA FILHO, é princípio que decorre dos direitos individuais estabelecidos no artigo $5 .^{\circ}$ da Constituição Federal, em especial, os relativos à liberdade de associação e de trabalho. Ela pode ser definida como sendo a liberdade para que os indivíduos atuem em qualquer negócio, contrato, empresa, ou no exercício de qualquer profissão, desde que, caso existam requisitos para tanto, eles sejam cumpridos ${ }^{336}$. Trata-se, portanto, de um exercício negativo

\footnotetext{
333 Comentário Contextual à Constituição, 3 ed., São Paulo, Malheiros, p. 709.

$334 \quad$ PAULA A. FORGIONI, Os fundamentos do Antitruste, cit., p. 273.

335 Princípios Constitucionais da Ordem Econômica, São Paulo, Revista dos Tribunais, 2005, p. 169170.

336 Nesse sentido, consultar a obra de EROS ROBERTO GRAU, A ordem econômica na constituição de 1988, cit., 1997.
} 
do Estado, ou seja, a abstenção de sua atuação. Por sua importância, especialmente no contexto da afirmação das liberdades individuais, a livre-iniciativa foi reconhecida na Encíclica do Papa João XXIII. É também fundamento da República Federativa do Brasil, está consagrada no artigo $170 \S$ único da Constituição Federal ${ }^{337}$ e está presente no artigo $1^{\circ}$ da lei Antitruste Brasileira ${ }^{338-339}$.

Em uma visão diferenciada, afirma GILBERTO BERCOVICI “A livre iniciativa, no texto constitucional de 1988 (artigos $1^{\circ}$, IV e 170, caput), não representa um triunfo do individualismo econômico, mas é protegida em conjunto com a valorização do trabalho humano, em uma ordem econômica com o objetivo de garantir a todos uma vida digna, com base na justiça social. Isso significa que a livre iniciativa é fundamento da ordem econômica constitucional no que expressa de socialmente valioso, o que não representa nenhuma novidade na tradição constitucional brasileira, pois a livre iniciativa está presente como fundamento da ordem econômica constitucional desde 1934. Portanto, a livre iniciativa não pode ser reduzida, sob pena de uma interpretação parcial e equivocada do texto constitucional, à liberdade econômica plena ou à liberdade de empresa, pois abrange todas as formas de produção, individuais ou coletivas, como a iniciativa econômica individual, a iniciativa econômica cooperativa (Artigos $5^{\circ}$, XVII,, e 174, § $3^{\circ}$ e $\S 4^{\circ}$, da Constituição) e a própria iniciativa econômica pública (Artigos 173 e 177 da Constituição, entre outros)."

Como típica característica do liberalismo econômico, traz, em seu âmago, a luta por uma posição secundária para do Estado na atividade econômica, devendo ser reservado a

337 É garantido "o livre exercício de qualquer atividade econômica, independentemente de autorização dos órgãos públicos, salvo nos casos previstos em lei”.

338 “Art. $1^{\circ}$ Esta lei dispõe sobre a prevenção e a repressão às infrações contra a ordem econômica, orientada pelos ditames constitucionais de liberdade de iniciativa, livre concorrência, função social da propriedade, defesa dos consumidores e repressão ao abuso do poder econômico".

339 Seu histórico está ligado ao fim das corporações de ofício, como nos explica o histórico de EROS ROBERTO GRAU: "O princípio da liberdade de iniciativa econômica - originalmente postulado no Édito de Turgot, de 9 de fevereiro de 1776 - inscreve-se plenamente no decreto d'Allarde, de 2-17 de março de 1791, cujo art. $7^{\circ}$ determinava que, a partir de $1^{\circ}$ de abril daquele ano, seria livre a qualquer pessoa a realização de qualquer negócio ou exercício de qualquer profissão, arte ou ofício que lhe aprouvesse, sendo contudo ela obrigada a se munir de uma 'patente' (imposto direto), a pagar as taxas exigíveis e a se sujeitar ao regulamento de polícia aplicáveis. Meses após, a chamada Lei Le Chapelier - Decreto de 14-17 de junho de 1791 - que proíbe todas as espécies de corporações, o princípio é reiterado" (A ordem econômica na constituição de 1988,cit., p. 225). 
ele papel supletivo, quando a atividade dos particulares for insuficiente. Em uma interpretação mais ampla e harmoniosa com o texto constitucional, isso não significa, obviamente, que o Estado deva permanecer alheio às atividades do mercado, servindo como mero corretor das falhas de mercado (a esse respeito, vide Capítulo 2), mas que sua atividade estaria limitada segundo ditames constitucionais. Como bem observa JOSÉ AFONSO DA SILVA, a liberdade de iniciativa deve ser entendida em uma Constituição preocupada com a justiça social e o bem-estar coletivo ${ }^{341}$.

Dessa forma, os agentes terão toda liberdade para atuar no mercado, iniciar e terminar os seus negócios da forma que melhor entenderem, realizando seus lucros ou prejuízos, desde que de acordo com os ditames constitucionais e dentro da legislação que regula as atividades econômicas ${ }^{342}$.

A liberdade de iniciativa, entretanto, não está ligada apenas à liberdade de ação dos indivíduos. Como já foi possível verificar, existem situações nas quais a atuação dos grandes agentes, pode ser um empecilho para que outros, especialmente os menores, possam efetivamente participar do jogo concorrencial do mercado, principalmente nas situações em que ocorre abuso de poder econômico. Também aqui há que se falar em defesa da livre iniciativa, entretanto, estamos falando de uma ação positiva do Estado para garantir que a livre iniciativa não seja prejudicada pela ação dos particulares. ADITYA BHATTACHARJEA nos traz um exemplo bastante interessante sobre, demonstrando que conceder-se alcance muito grande para a liberdade de iniciativa pode resultar, ao final, na destruição da concorrência entre agentes econômicos: "While 'greenfield' FDI (foreign direct investment) would generally introduce more competition into a market, it has been

\footnotetext{
341 Comentário Contextual à Constituição, cit., p. 711.

342 "Não se pode negar que a partir do momento em que o Estado passa a ser 'intervencionista' (e nessa expressão não vai qualquer carga ideológica) há uma modificação no próprio princípio da livre-iniciativa que, já muito, deixou se ser correlato a uma política de laissez-faire. A atuação do Estado sobre a economia, cada vez mais, não é tida como indesejável pelo sistema jurídico que, ao contrário, a institui e regulamenta. É bastante natural, entretanto, que quando nos referimos à 'livre-iniciativa', tenhamos em mente o conceito tradicional de liberdade (sensibilidade e acessibilidade a alternativas de conduta e de resultado e pensemos no agente econômico atuando no mercado, com o mínimo de 'repressão' estatal. Mas - insistimos - essa visão de livre-iniciativa, para que continue existindo, deve ser não apenas regulamentada, mas também conduzida pela autoridade governamental. Assim, o princípios da livre-iniciativa (e da livre concorrência) abriga-se, também, a atuação estatal no sentido de (i) disciplinar comportamentos que resultariam em prejuízos à concorrência e (ii) disciplinar a atuação dos agentes econômicos, de forma a implementar uma política pública, dando concreção os ditames do art. $3 .^{\circ}$ e do art. $170 \mathrm{da} C \mathrm{CF}$. em conclusão, quando a autoridade antitruste autoriza ou coíbe determinado comportamento do agente econômico, deve atuar o princípio da livre-iniciativa e da livre concorrência, tal qual modernamente concebidos e existentes no seio de nossa Constituição" (PAULA A. FORGIONI, Os fundamentos do Antitruste, cit., p. 273).
} 
observed that a very large proportion of FDI recent years has taken the form of mergers or acquisitions of domestic firms in order to gain control of their assets, especially capacity and marketing networks. If these domestic firms were rivals of the acquirer, this would reduce competition. In order to attract FDI, some developing countries also deliberately reduce competition by granting exclusive selling or mining rights to foreign form. Thus, the need to safeguard competition remains even on a liberalized economy. In any case, markets in developing countries are typically small in economic terms, and therefore many industries tend to be dominates by a handful of firms even if there are no legal restrictions on entry",343.

Dentro da situação ora descrita, torna-se evidente como nenhum dos princípios ou fundamentos da Carta Magna pode ser aplicado de forma absoluta, sem qualquer tipo de ponderação com o restante do ordenamento: o emprego descontextualizado da livreiniciativa (em seu aspecto negativo, ou seja, de ausência do Estado) poderia levar a uma situação na qual os pequenos agentes de mercado teriam tolhido o seu direito de exercício da garantia constitucional, visto que a ação dos agentes de maior porte lhes retiraria essa possibilidade. É certo que em uma situação como esta não há que se falar em cumprimento do texto constitucional, mas em incorreta utilização isolada de um dos preceitos trazidos pelo constituinte, que tornaria a liberdade de uns em limitação do exercício da liberdade por outros.

Com relação à utilização dos cartéis de exportação, não podemos nos esquecer que o constituinte declara que a ordem econômica, fundada na livre-iniciativa, "tem por fim assegurar a todos existência digna, conforme os ditames da justiça social”. Mais uma vez, o legislador é claro ao colocar um fim social para a ordem econômica e em afirmar que esse fundamento está atrelado à consecução de alguns objetivos, não devendo ser realizada de forma isolada.

Observou-se ao longo do Capítulo 1 que os cartéis de exportação são meio hábil a estimular a atividade interna, o aumento das exportações e o desenvolvimento econômico e nacional. Dentro dessa lógica, seus resultados estão em linha com os objetivos traçados para a ordem econômica. No mais, não encontramos qualquer contradição entre a existência das associações para exportação e o fundamento constitucional ora em comento:

343 ADITYA BHATTACHARJEA, Trade and Competition Policy, Indian council for research on international economic relations, cit., p. 3. 
sua utilização em nada altera a liberdade de atuação dos agentes no mercado, especialmente pelo fato das atividades conjuntas se limitarem ao mercado exterior. Nessa esteira, a existência dos cartéis de exportação sequer altera a dinâmica concorrencial dos players dentro do mercado nacional (não havendo que se falar, portanto, no surgimento de qualquer poder de mercado que possa se opor ao surgimento de novas empresas).

A única ressalva que poderia ser feita é no sentido de a restrição imposta pelo Estado estar embasada em fins superiores, traçados juridicamente (ou seja, que não seja fruto de arbítrio), e que não possam ser alcançados de forma diversa, sem causar restrição não justificável aos particulares. Nesse sentido, a formação das associações para exportação não poderia derivar de uma imposição do Estado, mas de um acordo formado pela livre vontade pelos exportadores brasileiros ${ }^{344}$.

\subsubsection{A livre concorrência ${ }^{345}$}

A livre concorrência foi elevada à categoria de princípio da ordem econômica, por meio do artigo 170 , inciso IV. A proteção também consta do artigo $173, \S 4 .^{\circ}$ do texto constitucional $^{346}$ e do artigo $1^{\circ}$ da lei Concorrencial brasileira. O princípio pode ser resumido como a possibilidade de os agentes atuarem no mercado, trabalhando de modo autônomo, no mesmo mercado competitivo, sem limitações quanto à forma e localidade,

\footnotetext{
344 "Por outro lado, como toda iniciativa estatal entranha uma restrição à plena liberdade econômica, sonhada pelo liberalismo, mas que embasa ainda a organização econômica ocidental, será necessária também a certeza de que o seu sacrifício, ainda que parcial, tenha, como contra partida efetiva, a obtenção de fins superiores inalcançáveis sem aquela restrição, sem que isso redunde em desmedido e não autorizado poder, quer para outros agentes do setor privado, quer para administradores do setor público. Em suma, o que se impõe é a perfeita institucionalização do processo de elaboração e aplicação da política econômica, tornandoo eminentemente jurídico no sentido de assegurar a liberdade possível aos agentes econômicos, a sua participação nas decisões, que de uma maneira ou de outra os afetarão, a certeza quanto à aderência aos princípios informadores básicos e quanto à idoneidade técnica" (FABIO NUSDEO, Fundamentos para uma codificação do Direito Econômico, cit., p. 39).

345 "O texto da Constituição de 1988 não deixa dúvidas quanto ao fato de a concorrência ser, entre nós, um meio, um instrumento para o alcance de outro bem maior, qual sela, 'asseguras a todos existência digna, conforme os ditames da justiça social” (PAULA A. FORGIONI, Os fundamentos do Antitruste, cit., p. 190191).

346 “Artigo 173. [...] $§ 4 .^{\circ}$ A lei reprimirá o abuso de poder econômico que vise à dominação dos mercados, à eliminação da concorrência e ao aumento arbitrário dos lucros.”
} 
na busca por clientela e por lucro, sendo exceções à essa liberdade unicamente aquelas legalmente estabelecidas ${ }^{347}$.

Para ANA MARIA DE OLIVEIRA NUSDEO, o princípio da livre concorrência é instrumental ao da livre-iniciativa, sendo utilizado como balizador para o seu exercício. Nessa medida, a livre-iniciativa pode ser exercida desde que se mantenham no mercado condições paras que outros agentes econômicos também desfrutem dele, ou seja, desde que se existam condições de concorrência.

A aplicação desse conceito é bastante controversa, e é por intermédio dele que são travadas as discussões características da Escola de Chicago. Explica-se: tendo o legislador eleito a livre concorrência como um dos princípios da ordem econômica, os adeptos das teorias neoclássicas pretendem exacerbar a sua utilização, sempre na busca pela eficiência econômica em uma tentativa de elevar o princípio constitucional a fim único a ser perseguido pela ordem econômica brasileira (a esse respeito, consultar o Capítulo 2$)^{348}$.

Essa interpretação não é conforme o disposto no ordenamento jurídico brasileiro. Conforme já afirmamos, a livre concorrência é um dos princípios estabelecidos para a ordem econômica, devendo ser harmonizado com os demais. Não se busca a concorrência pela concorrência, mas a concorrência na medida em que ela possa se amoldar dentro do quadro estabelecido pela Lei Maior, na busca de existência digna a todos ${ }^{349}$. JOSÉ

347 J. CRETELLA JÚNIOR, Direito concorrencial - Aspectos Jurídicos e Econômicos, Rio de Janeiro, América Jurídica, 2002, p. 73. TULLIO ASCARELLI associa o princípio da livre concorrência à tutela do consumidor e do progresso técnico, nos seguintes termos: "O princípio da livre concorrência baseia-se na dupla tutela do consumidor e do progresso técnico. A concorrência obriga os produtores a procurarem, constantemente, a melhoria de seus produtos e a diminuição de seus custos. Beneficia-se assim o consumidor, erigido em juiz da luta entre os vários produtores, ficando estimulado o progresso técnico. Os ajustes entre produtores, regulamentando a concorrência recíproca, dão origem, por isso a um problema fundamental: o do contraste entre as finalidades dêstes ajustes e o princípio da livre concorrência, o da substituição e uma economia livre por uma economia planificada pelos produtores, levados antes, pelo intuito de conseguir o maior lucro possível, do que pelo de melhorar o produto, ou baixar o preço" (Ensaios e Pareceres, São Paulo, Saraiva, 1952, p. 223).

348 "Em presença do Estado, no entanto, a proteção da concorrência não se pode resumir à garantia do funcionamento da mão invisível Smithiana. Nesse caso não é possível propugnar pela coincidência entre Constituição Econômica (em sentido material) e direito concorrencial. O Estado introduz, pelo menos em certas áreas, uma forma de organização das relações econômicas que não se rege pela lógica concorrencial. Alias é exatamente a divisão de esferas entre o Estado regulador e intervencionista e aquele que se limita a organizar as forças do mercado através da aplicação do direito concorrencial que melhor define o ordenamento econômico existente ou, se assim se preferir, a Constituição Econômica de cada ordenamento" (CALIXTO SALOMÃO FILHO, Direito concorrencial - as estruturas, cit., p. 21).

349 Nas palavras de EROS ROBERTO GRAU: “[...] de acordo com a Constituição do Brasil, a concorrência, no Brasil, não é um fim em si mesmo, mas um instrumento que deve ser utilizado tendo-se em 
MARCELO MARTINS PROENÇA assim resume o assunto: "a concorrência, na ordem econômica brasileira, é um valor apenas orientador, informador, que pode ser ferido, sacrificado, com vistas à consecução de outras iniciativas para dar uma vida mais digna ao cidadão brasileiro, iniciativas essas que podem ser, com o direito da concorrência, incompatíveis" ${ }^{350-351 .}$.

O Supremo Tribunal Federal já se manifestou inúmeras vezes no sentido de considerar a livre concorrência como princípio a ser adequado com o sistema global da Constituição Federal. Nesse sentido o voto do Ministro MOREIRA ALVES: “(...) embora um dos fundamentos da ordem econômica seja a livre-iniciativa, visa aquela assegurar a todos existência digna, em conformidade com os ditames da justiça social, observando-se os princípios enumerados nos sete incisos deste artigo. Ora, sendo a justiça social a justiça distributiva - e por isso mesmo é que se chega à finalidade da ordem econômica (assegurar a todos existência digna) por meio dos ditames dela -, e havendo a possibilidade de incompatibilidade entre alguns dos princípios constantes dos incisos deste artigo 170, se tomados em sentido absoluto, mister se faz, evidentemente, que se lhes dê sentido relativo para que possibilite a sua conciliação a fim de que, em conformidade com a justiça distributiva, se assegure a todos -, e portanto, aos elementos de produção e distribuição de bens e serviços e aos elementos de consumo deles - existência digna"352.

vista a realização dos objetivos do Brasil (art. 3. ${ }^{\circ}$ ), e da ordem econômica (art. 170)" (PAULA A. FORGIONI, Os fundamentos do antitruste, cit., p. 8).

$350 \quad$ Concentração empresarial e Direito da Concorrência, São Paulo, Saraiva, 2001, p. 412.

$351 \quad$ "Embora a concorrência seja reconhecidamente um processo que estimula o uso eficaz e a alocação eficiente dos recursos da sociedade, a supremacia desse propósito não é uniformemente aceita. Além disso, há controvérsia quanto ao que configura uma restrição privada à concorrência. A importância relativa e o equilíbrio entre a eficiência e os vários outros objetivos econômico-sóciopolíticos que a política da concorrência pode favorecer ainda precisam ser identificados”. SHYAN KHEMANI (org.), op. cit., p. 35.

352 Ação Direta de Inconstitucionalidade 319-4-DF, julgada em 03 de março de 1993, DJ 30.04.1993. No mesmo sentido, Ação Direta de Inconstitucionalidade 1950-SP, assim ementada: "1. É certo que a ordem econômica na Constituição de 1.988 define opção por um sistema no qual joga um papel primordial a livreiniciativa. Essa circunstância não legitima, no entanto, a assertiva de que o Estado só intervirá na economia em situações excepcionais. 2. Mais do que simples instrumento de governo, a nossa Constituição enuncia diretrizes, programas e fins a serem realizados pelo Estado e pela sociedade. Postula um plano de ação global normativo para o Estado e para a sociedade, informado pelos preceitos veiculados pelos seus artigos $1 .^{\circ}, 3 .^{\circ} \mathrm{e}$ 170. 3. A livre-iniciativa é expressão de liberdade titulada não apenas pela empresa, mas também pelo trabalho. Por isso a Constituição, ao contemplá-la, cogita também da 'iniciativa do Estado'; não a privilegia, portanto, como bem pertinente apenas à empresa. [...] Na composição entre esses princípios e regras há de ser preservado o interesse da coletividade, interesse público primário [...]”. Ministro Relator Eros Roberto Grau, julgada em 03 de novembro de 2005, DJ 02.06.2006, p. 4; Recurso Extraordinário 432789-SC, Ministro Relator Eros Roberto Grau, julgado em 14 de junho de 2005, DJ 07.10.2005, p. 27; e Ação Direta de Inconstitucionalidade 3512-SP, Ministro Relator Eros Roberto Grau, julgada em 15 de fevereiro de 2006, DJ 
Em termos práticos, caso erijamos a livre concorrência a único pilar da ordem econômica, deveríamos admitir, a título de exemplo, que uma empresa exercendo seu poder de mercado cobre preços altíssimos sobre a matéria-prima de outra, o que levaria ao seu fechamento. Caso o princípio da livre concorrência fosse absoluto e prevalecesse sobre os demais, deveríamos ignorar que, nesse caso, a livre concorrência feriria o fundamento da livre-iniciativa e levaria ao desemprego de muitas pessoas, lesando ainda outro princípio da ordem econômica, que é o do pleno emprego ${ }^{353}$.

A compatibilização do livre mercado com os demais dispositivos da Carta Magna não é uma escolha ideológica, mas simplesmente o atendimento ao quando disposto na Constituição. É sobre essa visão - de compatibilização - é que devemos discutir a utilização dos cartéis de exportação.

Dentro dessa realidade, os cartéis de exportação, a despeito de poderem ser considerados por muitos como instrumentos de infração ao artigo 170, IV, da Constituição Federal, devem ter sua análise realizada de acordo com o todo. Assim, como já visto, podem ser fonte do cumprimento de objetivos da República Federativa do Brasil e de outros princípios dispostos no artigo 170. Ademais, é de se afirmar que a utilização dos

23.06.2006, p. 03; e ainda “[...] A defesa da livre concorrência é imperativo de ordem constitucional (art. 170 , inc. IV) que deve harmonizar-se com o princípio da livre iniciativa (art. 170, caput). Lembro que 'livre iniciativa e livre concorrência, esta como base do chamado livre mercado, não coincidem necessariamente. Ou seja, livre concorrência nem sempre conduz à livre iniciativa e vice-versa (cf. Farina, Azevedo, Saes: Competitividade: Mercado, Estado e Organizações, São Paulo, 1997, cap. IV). Daí a necessária presença do Estado regulador e fiscalizador, capaz de disciplinar a competitividade enquanto fator relevante na formação de preços ...' Calixto Salomão Filho, referindo-se à doutrina do eminente Min. Eros Grau, adverte que 'livre iniciativa não é sinônimo de liberdade econômica absoluta [...]. O que ocorre é que o princípio da livre iniciativa, inserido no caput do art. 170 da Constituição Federal, nada mais é do que uma cláusula geral cujo conteúdo é preenchido pelos incisos do mesmo artigo. Esses princípios claramente definem a liberdade de iniciativa não como uma liberdade anárquica, porém social, e que pode, consequentemente, ser limitada. [...].Não se trata aqui de reduzir a defesa da liberdade de concorrência à defesa do concorrente, retrocedendo aos tempos da 'concepção privatística de concorrência', da qual é exemplo a 'famosa discussão sobre liberdade de restabelecimento travada por Rui Barbosa e Carvalho de Mendonça no caso da Cia. de Juta (Revista do STF (III), 2/187, 1914)', mas apenas de reconhecer que o fundamento para a coibição de práticas anticoncorrenciais reside na proteção a 'ambos os objetos da tutela: a lealdade e a existência de concorrência [...]. Em primeiro lugar, é preciso garantir que a concorrência se desenvolva de forma leal, isto é, que sejam respeitadas as regras mínimas de comportamento entre os agentes econômicos. Dois são os objetivos dessas regras mínimas. Primeiro, garantir que o sucesso relativo das empresas no mercado dependa exclusivamente de sua eficiência, e não de sua 'esperteza negocial' - isto é, de sua capacidade de desviar consumidores de seus concorrentes sem que isso decorra de comparações baseadas exclusivamente em dados do mercado.' [...]. Ação Direta de Inconstitucionalidade 3112, Ministro Relator Ricardo Lewandowski julgada em 02 de maio de 2007, DJ 20.10.2007.

353 “(...) os economistas defendem que a política da concorrência precisa reconhecer os efeitos que práticas comerciais como as fusões podem causar sobre o emprego, o esfacelamento de comunidades e o desenvolvimento regional, por meio do fechamento de fábricas e da reorganização das fontes de material e das decisões financeiras, de produção e distribuição”. Shyan Khemani (org.), op. cit., p. 34. 
cartéis de exportação puros não afetará de forma alguma a concorrência dentro do território brasileiro. Conforme observamos no Capítulo 4, a atuação desse tipo de acordo entre concorrentes se dá unicamente no mercado externo (nas exportações), não tendo qualquer influência sobre a forma pela qual ocorrem as transações no mercado interno. Dessa maneira, a livre concorrência continuaria a funcionar da mesma forma, independentemente de sua existência.

\subsubsection{A soberania nacional}

Soberania é a característica de um Estado de não se submeter a qualquer outro poder mais alto ou superior a ele. É declarada como fundamento da República Federativa do Brasil no artigo 1. ${ }^{\circ}$ da Constituição. Sua repetição no artigo 170 certamente não foi obra do acaso $^{354}$. Mas qual seria o significado da inserção da soberania dentro da Constituição Econômica?

Evidentemente, o constituinte pretendia que, na condução dos assuntos econômicos o Brasil fosse guiado pelo interesse nacional. Essa autordeterminação na condução de sua política econômica revela-se especialmente importante quanto nos recordamos que a influência econômica de um país sobre outro pode ser bastante prejudicial para a economia do país dominado. O período colonial de inúmeros países nos relevam tempos nos quais a transferência de riquezas foram tamanhas que ainda hoje seus reflexos são sentidos pelas populações locais.

Voltando a assunto já discutido ao longo do Capítulo 6, LUIZ CARLOS BRESSER-PEREIRA nos traz relevantes aspectos sobre o comércio internacional que podem justificar a preocupação do constituinte pátrio. Segundo o autor, nas últimas décadas, ter-se-ia verificado a tendência de se "menosprezar" ou se relativizar o conceito de soberania, em prol do conceito de globalização e de abertura dos mercados nacionais. Essa depreciação traria consigo a idéia de que os Estados não seriam mais importantes como agentes propulsores do comércio internacional, sendo sua atuação indesejada e

$354 \quad$ "Introduziu a 'soberania nacional', que tudo indica deva ser com o intuito de definir o 'nacionalismo econômico' pela sua localização na Constituição Econômica, visto como em termos políticos a 'soberania' já se achava corretamente colocada nos 'Princípios fundamentais' introdutórios de toda a Constituição (art. 1. ${ }^{\circ}$, I)" (WASHINGTON PELUSO ALBINO DE SOUZA, A experiência brasileira de Constituição econômica, In Revista Brasileira de Estudos Sociopolíticos, n. 67/68, jul. 1988 a jan. 1989, p. 108). 
contrária aos princípios da economia de mercado. As trocas internacionais seriam comandadas pelas grandes empresas, transnacionais, sem nacionalidade definida. O cenário construído torna a antiga idéia de soberania, tão prezada pelas nações, caricata e inadequada ${ }^{355}$.

Ocorre que, como também já foi observado, a tentativa de destruir o conceito é inadequada. Tanto pelo fato de não passarem de discurso vazio por parte daqueles que pregam a inadequação da soberania no contexto do comércio internacional, quanto pelo fato de a nossa Constituição ter expressamente ressalvado o conceito na Constituição Econômica.

Com relação ao primeiro ponto, verificou-se que os países que pretensamente adotam as teorias do liberalismo econômico, não se cansam de continuamente demonstrar que, em se tratando da defesa de seus próprios interesses, o Estado é rapidamente chamado a agir. A titulo de exemplo, temos a política dos Estados Unidos com relação a seu setor agrícola e até mesmo a permissão de utilização dos cartéis de exportação ${ }^{356}$. Ou será que podemos dizer que a "livre mão do mercado" está agindo quando aquele país resolve proteger por meio de alíquotas a sua indústria de suco de laranja ${ }^{357}$ ?

Por outro lado, ainda que o que já foi dito não fosse relevante, temos que observar o que a Constituição nos diz sobre o assunto. Não podemos supor que a repetição do princípio da soberania na parte econômica da Carta Magna se deu sem razão. E o motivo para tanto parece ser obvio: ao longo de seu texto, o constituinte deixa clara a necessidade 355 LUIZ CARLOS BRESSER-PEREIRA, Desenvolvimento econômico e revolução capitalista, cit.

356 Nesse sentido, a descrição que HA-JOON CHANG nos traz sobre o lendário MITI: "No Japão, o famoso MITI (Ministry of International Trade and Industry) orquestrou um programa de desenvolvimento industrial que se tornou uma lenda. As tarifas industriais do Japão não eram particularmente elevadas após a Segunda Guerra Mundial, mas a importação de divisas era estritamente controlada pelo governo. As exportações eram promovidas para maximizar a oferta de moeda estrangeira necessária para adquirir tecnologias melhores (ou por meio da compra de máquinas ou da compra de licenças de tecnologia). Isso envolveu subsídios diretos e indiretos às exportações, assim como as informações e ajuda de marketing do JETRO (Japan External Trade Organization), a agência de comércio governamental” (Op. cit., p. 57.)

357 Mesmo em tempos nos quais a busca pelo liberalismo econômico estava no seu auge, o Estado sempre manteve as rédeas curtas com relação à sua política econômica, dadas suas nítidas influências na condução do Estado. Nesse sentido: "Todavia, na realidade, o desinteresse do Estado pela vida econômica foi muito mais aparente do que real. Ele não poderia deixar de almejar uma pujante atividade produtora com vistas a ter o necessário suporte para a estabilidade interna e para possível hegemonia externa. Dela precisava, quando mais não fosse, para bem poder armar os seus exércitos. E havia, igualmente, em muitos meios, a preocupação social, pura e simples, que aflorava ora cá ora lá, como bem exemplifica a história do constitucionalismo francês" (FÁBIO NUSDEO, Fundamentos para uma codificação do Direito Econômico, cit., p. 13). 
de que a República Federativa do Brasil atinja certos objetivos, como os elencados no artigo $3^{\circ}$. Não há dúvidas sobre o fato de que o Estado desempenha papel fundamental nessa busca, como agente a guiar o desenvolvimento nacional, a erradicação da pobreza, entre outros. Assim, é imprescindível que ele atue, também na esfera internacional, na busca de seus interesses. ${ }^{358}$

Isso não significa, de nenhuma forma, o isolamento internacional, como explica JOSÉ AFONSO DA SILVA: “[...] o constituinte de 1988 não rompeu com o sistema capitalista, mas quis que se formasse um capitalismo nacional autônomo, isso é, não dependente. Com isso, a Constituição criou as condições jurídicas fundamentais para a adoção do desenvolvimento autocentrado, nacional e popular, que, não sendo sinônimo de isolamento ou autarquização econômica, permite marchar para um sistema econômico desenvolvido $[\ldots]^{359}$. Com efeito, a atuação independente não significa a ruptura com a ordem internacional, muito ao contrário, o que se sustenta é que o Brasil, em suas relações com os demais Estados, deva agir com vistas a atingir os fins determinados pela Constituição Federal. Já observamos em inúmeros trechos desse trabalho que países com

\footnotetext{
358 Sobre o problema da soberania brasileira, GILBERTO BERCOVICI: "Desta forma, a falta de integração social, econômica, e política continua exigindo uma atuação do Estado, inclusive para a conclusão do projeto de formação nacional, ultrapassando a barreira do subdesenvolvimento. Todos esses dilemas e desafios levantados sobre a especificidade do Estado brasileiro estão intrinsecamente ligados, em nossa opinião, à questão da soberania, que também permite reflexões conjuntas sobre o direito e a política. A soberania, qualidade essencial do Estado é também aqui entendida como sinônimo de poder do Estado, cuja unidade não impede a divisão vertical (federalismo) ou horizontal (organização dos poderes) de seu exercício. Portanto, a necessidade de fortalecer e reestruturar o Estado para a promoção do desenvolvimento passa, em nossa opinião, pela compreensão da soberania estatal tanto em seu aspecto interno como externo. Ambos os aspectos da soberania, absoluta internamente e relativa externamente são indissociáveis [...]". Maria Paula Dallari Bucci, (org.) Políticas Públicas, cit., p. 158. Sobre a soberania econômica nacional, afirma o mesmo autor: "A soberania econômica está prevista formalmente no Artigo 170, I, da Constituição de 1988, como um princípio da ordem econômica. No entanto, a soberania econômica deve ser entendida como em conjunto com o Artigo $3^{\circ}$, II, que declara o desenvolvimento nacional como um dos objetivos da República, e o Artigo 219 da Constituição, que integra o mercado interno ao patrimônio nacional" (JOSÉ CELSO CARDOSO JR (coord), cit., p. 259).
}

Op. cit., p. 767. Ainda nesse sentido, EROS ROBERTO GRAU: “A afirmação da soberania nacional econômica não supõe o isolamento econômico, mas antes, pelo contrário, a modernização da economia - e da sociedade - e a ruptura de nossa situação de dependência em relação às sociedades desenvolvidas. (...). Afirmar a soberania econômica nacional como instrumento para a realização do fim de assegurar a todos existência digna e como objetivo particular a ser alcançado é definir programa de políticas públicas voltadas - repito - não ao isolamento econômico, mas a viabilizar a participação da sociedade brasileira, em condições iguais, no mercado internacional" (A ordem econômica na constituição de 1988, cit., p. 247-248). 
melhores índices de desenvolvimento, como Alemanha, Japão e Estados Unidos, não se cansam de tomar atitudes que refletem a proteção de seus próprios interesses ${ }^{360}$.

Um bom exemplo de comportamento econômico independente, mas dentro da ordem internacional foi o tomado pela Índia e outros países na reunião interministerial da OMC de 2001 sobre o tema cartéis: embora reconheçam os malefícios trazido por esses instrumentos, não aceitaram a imposição de um documento que, na sua elaboração, não atendida às sua especificidades econômicas, sociais e políticas, desenvolvido tendo em vista a realidade dos países desenvolvidos ${ }^{361}$.

Aplicando-se o quanto desenvolvido ao tema dos cartéis de exportação, vemos um quadro de ampla compatibilidade. O Brasil deve, dentro do princípio da soberania declarado pela Lei Maior, avaliar a possibilidade de e conveniência da utilização dos cartéis de exportação tendo em vista o seu ordenamento jurídico. Ao que estudamos até o momento, não há qualquer dispositivo a impedir tal uso..

7.3.5. A redução das desigualdades regionais e sociais, a busca pelo pleno emprego e o tratamento favorecido para as empresas de pequeno porte constituídas sob as leis brasileiras

A constituição estabelece que o Estado deve atuar no sentido da diminuição das desigualdades regionais (que também é objetivo fundamental da República Federativa do Brasil, estatuído no artigo $3 .^{\circ}$ da Constituição Federal) e da concessão de oportunidade de trabalho a todos.

\footnotetext{
360 “discriminações são [...] praticadas mesmo pelos Estados desenvolvidos, em defesa da economia nacional, em nome do princípio da sua soberania" (EROS ROBERTO GRAU, op. cit., p. 33).

$361 \quad$ "While acknowledging the harm caused by international cartels, India and many other developing countries emphasized the need to respect their diversity in term of stages of development, sócio-economic circumstances, legal frameworks, and cultural norms. They opposed 'one size fits all' agreement, and drew attention to the dangers of transplanting a competition policy framework that has evolved over many years in industrial countries into economies lacking in experience, expertise, and institutional memory. Several developing countries claimed that development required giving greater priority to policy objectives other than the promotion of competition, and questioned virtually every proposal advanced by the proponents, including the necessity of applying the fundamental WTO principles of non discrimination, transparency and procedural fairness to competition policy" (ADITYA BHATTACHARJEA, Trade and Competition Policy, Indian council for research on international economic relations, cit., p. 3).
} 
O pleno emprego, nas palavras de JOSÉ AFONSO DA SILVA pode ser assim definido: “[...] propiciar trabalho a todos quantos estejam em condições de exercer uma atividade produtiva. Trata-se do pleno emprego da força capaz. Ele se harmoniza, assim, com a regra de que a ordem econômica se funda na valorização do trabalho humano. Isso impede que o princípio seja considerado como a mera busca quantitativa, em que a economia absorva a força de trabalho disponível, como o consumo absorve as mercadorias. Quer-se que o trabalho seja a base do sistema econômico, receba o tratamento de principal fator de produção e participe do produto da riqueza e da renda em proporção de sua posição na ordem econômica",362.

Obviamente, a conquista de tais objetivos não poderia ser implementada caso considerássemos o Estado brasileiro como mero expectador e garantidor do funcionamento da mão invisível do mercado. Dessa forma, justifica-se a adoção pelo Estado de mecanismos e políticas que podem ajudar na consecução desses objetivos. Note-se que, não raramente, essa ação não seria "em prol do mercado" mas, ao contrário, poderia ter uma conotação "contra o mercado", na medida em que poderia ser contrária às leis suas leis naturais ${ }^{363}$.

Nesse sentido, os cartéis de exportação podem ser instrumentos adequados a que se implementem políticas públicas adequadas ao atingimento dos objetivos traçados por nossa constituição. Conforme já analisamos, são instrumentos para incremento das exportações nacionais. Por conseqüência, poderão ser meios úteis à busca do pleno emprego. Da mesma forma, se bem empregada, a riqueza por eles trazida pode ser fonte de redução das desigualdades nacionais. Com relação ao tratamento favorecido das empresas de pequeno porte, o mesmo pode ser afirmado. Os cartéis de exportação são, em verdade, meios de tratamento favorecido para aquelas empresas que pretendem exportar os seus produtos, colocando-os no mercado externo em melhores condições de competição.

362 Comentário Contextual à Constituição,cit., p. 714.

363 "É fácil perceber a natureza profundamente conflitiva - e daí o aspecto problemático - do processo de política econômica, pois ele implica a deliberada imposição de distorções ao sistema como um todo, tanto no seu segmento de mercado, quanto no segmento público voltado à correção ou complementação daquele. Em outras palavras, uma coisa é a ação oficial 'pro' mercado ou 'proeter' mercado e outra é a sua intervenção contra o mercado, isto é, no sentido de o levar a desempenho certamente diverso daquele que ostentaria caso a intervenção não se realizasse" (FÁBIO NUSDEO, Fundamentos para uma codificação do Direito Econômico, cit., p. 27). 
Assim, são realizações desse princípio, visto que o objetivo da isenção é justamente atingir essas empresas, que, isoladamente, não conseguiriam colocar seus produtos no exterior.

\section{4. $O$ artigo 219 da Constituição}

Para finalizar o estudo dos dispositivos constitucionais, entendemos ser importante verificar o teor do disposto no artigo 219 da Constituição: "O mercado interno integra o patrimônio nacional e será incentivado de modo a viabilizar o desenvolvimento cultural e sócio-econômico, o bem-estar da população e a autonomia tecnológica do País, nos termos de lei federal".

Flui clara do texto constitucional a preocupação do legislador com o mercado interno. O motivo da preocupação parece ser evidente: por meio do fortalecimento do mercado interno é possível se viabilizar o desenvolvimento social e econômico do país. GILBERTO BERCOVICI assim o define: “Ao integrar o mercado interno ao patrimônio nacional, este Artigo deve ser compreendido como um corolário da soberania econômica nacional(Artigo 170, I, da Constituição). O significado deste dispositivo é justamente a endogeneização do desenvolvimento tecnológico e a internalização dos centros de decisões econômicos, seguindo o programa de superação do subdesenvolvimento proposto por Celso Furtado e pela Cepal e incorporados no texto constitucional de $1988^{\text {„364 }}$.

O mercado é usualmente entendido na doutrina como um espaço de trocas ${ }^{365}$. Apesar de abstrato, é uma "entidade" presente no dia-a-dia do homem, conferindo valor às mercadorias nele trocadas.

Sua colocação no texto constitucional, entretanto, lança nova luz sobre o seu significado. Com efeito, qual seria o objetivo do constituinte ao inserir o mercado entre o patrimônio nacional? JOSÉ AFONSO DA SILVA responde assim a essa indagação: "Mas a Constituição, no texto sob consideração, dá ao mercado interno um valor para além desse significado econômico, ao integrá-lo no patrimônio nacional. Com esse sentido, o mercado

364 JOSÉ CELSO CARDOSO JR (coord), cit., p. 275.

365 Sobre o assunto, consultar PAULA A. FORGIONI, A evolução do Direito Comercial brasileiro: Da mercancia ao mercado, São Paulo, Revista dos Tribunais, 2009. 
adquire valor constitucional, que nos dá uma dimensão social, sob a idéia de quem em seu sentido puramente econômico, pode fixar preços, mas não pode fixar valores sociais, porque este é que têm que fixar a natureza e os limites dele".

A idéia do legislador parece caminhar no sentido de utilização do mercado interno para a promoção e atingimento de bens maiores, estabelecidos na Constituição e viabilizados por meio do emprego de políticas públicas. Nesse sentido, o mercado nacional deve ser utilizado, como patrimônio do Brasil, para a busca do desenvolvimento nacional e de redução das desigualdades, entre outros objetivos.

Obviamente, não podemos deixar de afirmar a afinidade existente entre os cartéis de exportação e a promoção do mercado interno. Seja por meio do influxo de capitais originado pela aquisição dos produtos brasileiros, seja pela maior demanda desses produtos, o que estimulará a industrialização interna, a maior utilização de mão-de-obra e todos os outros reflexos advindos da demanda pelos produtos brasileiros, os cartéis de exportação podem ser meios de incrementar o mercado interno, atendendo à demanda constitucional. 


\section{LEI ANTITRUSTE BRASILEIRA}

\subsection{Lei Antitruste brasileira}

Conforme já afirmando, a disciplina concorrencial não é nova no ordenamento jurídico brasileiro, sendo possível remontar a textos legais que datam da década de 1930. É somente na década de 1990, entretanto, com as reformas de caráter liberal, a abertura dos mercados e a edição da Lei 8884/94 que a legislação antitruste, da forma como a conhecemos, passa a desfrutar da notoriedade que hoje a caracteriza ${ }^{366}$. Segundo JOSÉ CRETELLA JÚNIOR, da leitura de sua Exposição de Motivos, resta claro ser ela destinada à repressão ao abuso de poder econômico, à dominação de mercado, à eliminação da concorrência e ao aumento arbitrário dos lucros ${ }^{367}$.

Essa finalidade, entretanto, deve ser conjugada e harmonizada com aos ditames constitucionais que acabamos de examinar. Essa necessidade decorre de dois pontos principais, também já discutidos: o primeiro é que a Constituição Federal é o vértice do ordenamento jurídico brasileiro e, nessa medida, todo o restante da legislação (que lhe é inferior) deve, obrigatoriamente, se coadunar a seus ditames, sob pena de inconstitucionalidade; o segundo é que, como afirmamos no Capítulo 2, entendemos que o direito concorrencial é um ferramental que se presta à implementação de políticas públicas e, nessa esteira, deve ser um fator a viabilizar os objetivos traçados constitucionalmente. A lei concorrencial, portanto, trata de uma concorrência instrumento - que pode ser sacrificada em prol de outros interesses - e não de uma concorrência fim, a ser buscada como um fim em si mesma.

Não é de se olvidar que inúmeros interesses podem procurar abrigo em seus termos. PAULA A. FORGIONI denomina de "jogo do interesse protegido" a decisão que se tomará para definir aquele que terá guarida em determinado caso concreto. Continua a autora informando que os demais, que naquela situação não encontraram proteção, não são

\footnotetext{
366 Para um notável histórico dos antecedentes da Lei 8884/94, consultar PAULA A. FORGIONI, Os fundamentos do Antitruste, cit.

367 JOSÉ CRETELLA JÚNIOR, Comentários à Lei Antitruste, 2. Ed,. Rio de Janeiro, Forense, 1996, p. 4.
} 
inválidos ou ineficazes, mas apenas não escolhidos ${ }^{368}$. Dessa maneira, fica claro que a autoridade, ao aplicar o direito, pode optar por proteger um ou outro interesse, que pode ou não ser a concorrência. Vimos no Capítulo 6 que a União Européia dispõe textualmente, em seu ordenamento, sobre outros objetivos, especialmente os de política industrial e social. Obviamente, essa flexibilidade na aplicação do direito não advém unicamente do seu texto, mas também de uma orientação na sua interpretação, que tende a privilegiar uma atuação mais ampla das autoridades concorrenciais.

Repise-se, por importante, que no Brasil, em linha com os princípios estabelecidos pela Constituição Federal, é possível que a concorrência seja sacrificada em prol da defesa de outros interesses ${ }^{369}$. Assim, o Conselho Administrativo de Defesa Econômica - CADE, quando do julgamento do caso concreto, está autorizado a privilegiar um interesse em detrimento de outro, amoldando o veredito às políticas públicas que o Estado entende necessárias para determinado setor ${ }^{370}$. Voltando-nos à discussão travada no Capítulo 2, em nosso ordenamento, portanto, não há que se falar em uma aplicação estrita dos ensinamentos da Escola de Chicago.

Essas considerações são de grande relevância para os fins deste trabalho. Caso consideremos a concorrência ou a eficiência como únicos fins para o direito concorrencial, poderiam ser encontrados grandes problemas para a adoção dos cartéis de exportação. Afinal, como observamos ao longo do Capítulo 4, em uma análise superficial, as associações para exportação são acordos entre concorrentes e, nessa medida, obstáculos à livre concorrência. Se esses efeitos anticoncorrenciais não puderem ser contrabalanceados

368 PAULA A. FORGIONI, Os fundamentos do Antitruste, cit., p. 263-264.

369 "Frise-se, desde já, que no exercício de sua função preventiva, nos ternos do $\S 1^{\circ}$ do art. 54 da Lei $n^{\circ}$ 8.884/94, poderá o CADE autorizar a formação de atos de concentração de empresas que possam limitar ou de qualquer forma prejudicar a livre concorrência, desde que propiciem eficiências (...) ou quando necessários por motivos preponderantes da economia nacional e do bem comum, desde que não impliquem prejuízo ao consumidor ou usuário final" (JOSÉ MARCELO MARTINS PROENÇA, Título VII das formas de controle, Capítulo I - Do controle de atos e contratos, cit., p. 375).

$370 \quad$ "As defesas relacionadas à política industrial - entre as quais o estímulo à pesquisa e ao desenvolvimento, apoio às empresas em crise ou a setores em depressão e estímulo para pequenas empresas , por sua vez, possibilitam a adaptação das normas de proteção à concorrência, principalmente das regras de controle de atos de concentração, às políticas econômicas implementadas pelo Estado no sentido de estimular a competitividade de seu parque produtor e amparar setores atingidos pelo novo contexto concorrencial. Sua consideração quanto ao exame dos atos de concentração permite a adaptação dessas operações, cuja realização se torne interessante por motivos de política econômica, às condições das leis de defesa da concorrência. Com efeito, embora possivelmente benefícios à sociedade, tais atos de concentração devem passar pelo crivo de seu efeito na concorrência, mediante a avaliação do poder mercado, eventualmente criado ou fortalecido" (ANA MARIA NUSDEO, op. cit., p. 18). 
os pontos benéficos - que somente poderão ser percebidos na medida em que se admitem outros objetivos para o direito concorrencial - seria bastante remota a possibilidade de que pudessem legalmente existir.

\section{2. Âmbito da lei Antitruste e extraterritorialidade}

Acabamos de discutir a forma que entendemos correta para emprego da legislação concorrencial - a de implementação de políticas públicas. Agora é chegado o momento de verificar qual a sua extensão.

Com relação aos sujeitos que estão sujeitos aos dispositivos antitruste, a lei brasileira, utilizando-se de linguagem clara, evitou qualquer celeuma, sendo taxativa, em seu artigo 15, sobre a sua aplicabilidade a pessoas físicas ou jurídicas, de direito público ou privado, bem como a quaisquer associações, com ou sem personalidade jurídica, mesmo que exerçam sua atividade em regime de monopólio ${ }^{371}$. Logo, quaisquer atos, de quaisquer pessoas, estão sujeitos à lei concorrencial, a não ser que ocorra uma das hipóteses de isenção ${ }^{372}$, objeto de futura análise.

De acordo com PAULA A. FORGIONI, a determinação da lei antitruste aplicável a um caso concreto é feita tendo em vista três fatores: i) a territorialidade; ii) o local no qual os efeitos do ato são verificados; e iii) a nacionalidade do agente. A adoção de um desses critérios não determina a exclusão dos outros, sendo comum que mais de um seja adotado para definir a competência para aplicação do direito.

O critério da territorialidade determina que ao caso concreto seja aplicada a lei antitruste do país no qual a prática anticompetitiva teve lugar. A Lei 8884/94 adota esse

\footnotetext{
371 “Artigo 15. Esta Lei aplica-se às pessoas físicas ou jurídicas, de direito público ou privado, bem como a quaisquer associações de entidades ou pessoas, constituídas de fato ou de direito, ainda que temporariamente, com ou sem personalidade jurídica, mesmo que exerçam atividade sob regime de monopólio."

372 Sob o manto da expressão "isenção" serão tratadas todas as forma de não aplicação da lei concorrencial, como a rule of reason, as isenções propriamente ditas e as autorizações.
} 
fator de ponderação em seu artigo $2^{0373}$ - ou seja, a lei brasileira poderá ser aplicada a qualquer prática cuja ação tenha ocorrido em território nacional.

O segundo e mais festejado critério é o que determina a competência do Estado de acordo com o local no qual os efeitos das práticas sejam verificados. FÁBIO ULHOA COELHO entende que a aplicação do direito antitruste brasileira deve ocorrer sempre que os efeitos do ato sejam sentidos em território nacional, ainda que se trate apenas de parte desses resultados ${ }^{374}$. Por meio desse entendimento, desposado por grande parte da doutrina, a lei concorrencial poderia ser aplicada, por exemplo, a um cartel de exportação organizado fora do território nacional que aqui produza efeitos. Muitos outros ordenamentos, como os Estados Unidos e a União Européia adotam esse mesmo entendimento $^{375}$.

As contendas na doutrina (e mesmo entre os países) são bastante freqüentes com relação à utilização desse conceito, também conhecido como "doutrina dos efeitos". Isso porque ele dá margem a que a aplicação do direito concorrencial de determinado país se estenda para além dos seus limites territoriais - ou seja, a jurisdição de determinado país passa a não mais se limitar aos atos que ocorrem dentro de seu território, alcançando aqueles que nele apenas produziram efeitos. A aplicação é tão conflituosa que um dos motivos apontados para adoção da "política internacional da concorrência" é o de se evitar conflitos territoriais na nessa aplicação.

O terceiro critério utilizado para a delimitação da competência é o da nacionalidade. Por meio desse entendimento, aplicar-se-ia o direito do país no qual estiverem as sedes das empresas que praticaram o ato anticompetitivo, ou, se estivermos tratando de pessoas físicas, do local de sua nacionalidade. Assim, se uma empresa alemã praticar abuso de poder dominante na Guatemala, as leis concorrenciais do Estado alemão

373 "Artigo $2^{\circ}$ Aplica-se esta lei, sem prejuízo de convenções e tratados de que seja signatário o Brasil, às práticas cometidas no todo ou em parte no território nacional ou que nele produzam ou possam produzir efeitos."

374 FÁBIO ULHOA COELHO, Direito antitruste brasileiro, São Paulo, Saraiva, 1995, p. 7 , corroborado por JOSÉ CRETELLA JÚNIOR: “As práticas, ou seja, as infrações cometidas no território nacional, 'no todo' ou 'em parte', ou que, no Brasil, produzam - ou possam produzir - conseqüências, ficam sob incidência desta Lei, além da aplicação sobre o infrator de dispositivos repressivos de convenções e tratados de que o Brasil seja parte, ou seja, signatário" (Comentários à Lei Antitruste, 2. ed., Rio de Janeiro, Forense, 1996, p. 14). 
deveriam ser aplicadas ao caso concreto, tendo em vista o fato de a empresa ter sede naquele país. Esse elemento de identificação acaba por tocar no problema da extraterritorialidade das leis concorrenciais, motivo pelo qual cabem aqui as mesmas considerações tecidas acima sobre a doutrina dos efeitos.

Aprofundando um pouco mais a questão, é de se supor que seja conflituosa a pretensão dos Estados de verem aplicadas suas legislações concorrenciais fora de seu próprio território. Obviamente, essa tentativa esbarra na jurisdição de outros países, que certamente se sentirão “desconfortáveis" com a ingerência externa ${ }^{376}$. Nas palavras de ROGER ALFORD: "Few subjects in international Law raise such incorrigible conflicts of interest as the exercise of extraterritorial jurisdiction in the antitrust context. As one commentator asked with respect to a U.S. court's assertion of jurisdiction over British defendants, '... how could American law, how could an American judgment applying American law possibly vary the rights and obligations created by an English contract to be performed outside the United States?' Indeed, international law is based on the notion that a state occupies a definite territory, within which it normally exercises jurisdiction"377.

A situação é realmente bastante complexa: por um lado, países se acham no direito de regular qualquer atividade que possa, ainda que potencialmente, afetar a sua concorrência interna, ou mesmo de disciplinar aqueles casos nos quais seus interesses econômicos estejam em jogo - é certo que essa atuação fora do território não deixam de ser uma forma de o Estado garantir a implementação de políticas públicas por meio das normas antitruste. Por outro lado, parece bastante difícil que qualquer país permita tal intervenção externa.

A aplicação da doutrina dos efeitos pode sofrer temperamentos, levando a maior ou menor rigor. O caso mais emblemático, e provavelmente responsável por grande parte da controvérsia existente, é o de sua interpretação nos Estados Unidos. A Seção 1 do Sherman Antitrust Act prevê que a legislação americana deva ser aplicada a quaisquer situações que

\footnotetext{
376 Para estudo mais aprofundado sobe o tema, consultar VLADIMIR PAVIC, Extraterritoriality in the matters of antitrust, European Press Academic Publishing, 2001.

377 The extraterritorial application of antitrust laws: The United States and the European Community approaches, In Virginia Journal of International Law, v, 33, n. 1, 1992, p. 1.
} 
possam afetar o mercado americano ${ }^{378}$. O dispositivo é bastante amplo e, como é costume naquele país, sua correta interpretação ficou a cargo do trabalho jurisprudencial.

Assim, no famoso caso Hartford Fire Insurance v. State of California ${ }^{379}$, a Corte Americana se pronunciou no sentido de que a legislação antitruste deveria ser aplicada a todas as condutas anticompetitivas que tivessem como objetivo ou que pudessem de alguma forma produzir efeitos dentro dos Estados Unidos. O precedente deu origem a um período no qual as tentativas de utilização da lei antitruste americana a condutas estrangeiras alcançaram níveis não toleráveis, chegando, não raras vezes, a serem entendidas como afronta à soberania de outros Estados. Como resposta a essa indevida ingerência, diversos países, como Inglaterra e Canadá, passaram a editar medidas com o intento de barrar as pesadas investidas americanas (as chamadas bloking laws) ${ }^{380}$. Nos

$378 \quad$ Do texto legal: "U.S.C. Title 15 , Chapter $1, \S 1 .^{\circ}$ Every contract, combination in the form of trust or otherwise, or conspiracy, in restrain of trade or commerce among the several States, or with foreign nations, is declared to be illegal. Every person who shall make any contract or engage in any combination or conspiracy hereby declared to be illegal shall be deemed guilty of a felony, and, on conviction thereof, shall be punished by fine not exceeding $\$ 100,000,000$ if a corporation, or, if any other person, $\$ 1,000,000$, or by imprisonment not exceeding 10 years, or by both said punishments, in the discretion of the court."

379

Hartford Fire Insurance v. State of California, 113 S. Ct. 2891, 2909 (1993).

380 As bloking laws inglesas deram origem a uma famosa discussão entre os professores LOWE e LOWEFELD, assim resumidas por LEONARDO ARQUIMIMO DE CARVALHO: "A discussão ganhou notoriedade em face de uma controvérsia surgida em 1981 entre os professores Lowe e Lowefeld. Tal controvérsia apresenta a visão de norte-americanos e britânicos em relação à competência internacional em matéria antitruste. Assim, as considerações dos britânicos, sintetizadas por LOWE: The Protection of Trading Interests Act de 1980 era baseado nas seguintes medidas: I - proibia obediência dos cidadãos britânicos às ordens emanadas de autoridades estrangeiras, com pretensão extraterritorial em prejuízo dos interesses comerciais britânicos; II - proibia a execução no Reino Unido, de julgamentos estrangeiros relacionados a práticas restritivas; III - estabelecia proteção dos negócios britânicos contra sentenças de tribunais estrangeiros que estabelecessem a obrigação de reparar danos por intermédio do procedimentos nos tribunais do Reino Unido. [...] A resposta às considerações do 'porta voz' dos interesses britânicos não tardou. Em julho de 1981, dois meses depois de LOWE expor suas razões, The American Journal of International Law publicou a réplica que contrapunha e justificava a postura dos EUA. Inicialmente, pensa LOWENFELD que o artigo de LOWE traz elementos anti-americanistas. Mas que demonstra as diferenças existentes entre a visão dos EUA e do Reino Unido em relação à regulamentação transnacional da atividade econômica; lembra que os EUA têm se esforçado para aplicar o princípio da razoabilidade como limitador do exercício da jurisdição. Combate ainda o argumento da soberania, entendendo que esta apresenta problemas em sua orientação se confrontada com a realidade atual. LOWEFELD entende que os estatutos britânicos de proteção de seus interesses são responsáveis pela conduta norte-americana em relação à regulamentação de atividades econômicas transnacionais. $\mathrm{O}$ entendimento norte-americano era bastante simples, segundo o ponto de vista de LOWENFELD. Para este, se determinadas empresas, todas elas norte-americanas, não pudessem reunir forças para estabelecer o preço de um produto vendido nos EUA, por que poderiam outras empresas, por exemplo, não norte-americanas, gozar de tal possibilidade? Ainda, se companhias norteamericanas e estrangeiras estabeleciam acordo anticompetitivo por que não deveriam ser responsabilizadas? Ou porque determinada companhia poderia promover ações fraudulentas nos EUA sem a possibilidade de imposição da lei norte-americana? E finalmente, por que as atividades que envolvessem diretamente dois ou mais Estados deveriam ser totalmente livres de regulamentação econômica, exceto se ambos os Estados impusessem o mesmo regulamento? Em resumo: se às companhias norte-americanas não seriam permitidas 
últimos anos, tem-se verificado o abrandamento dessas práticas, especialmente como reação às duras críticas recebidas no âmbito internacional. VLADIMIR PAVIC acredita que, a despeito de o caso Hartford Fire Insurance ser de extrema importância para a jurisprudência americana, ainda não representa o entendimento final de suas Cortes sobre a forma como a Seção 1 do Sherman Antitrust Act deverá ser interpretada ${ }^{381}$.

A utilização de variados critérios para a delimitação da competência leva, não raras vezes, a um conflito positivo, no qual mais de um Estado julga ter jurisdição sobre a mesma contenda. Um bom exemplo desse tipo de situação ocorre com os cartéis de exportação: o país A, no qual o conluio se formou (e que, portanto, exporta os produtos), oferece isenção para a prática e é competente para o julgamento do acordo, se tomarmos como base o critério a territorialidade. Por outro lado, o país B, importador, também se considerada competente para o seu julgamento, tendo em vista o fato de a formação do cartel provocar efeitos dentro de seu território. Dessa maneira, dois países podem se declarar competentes para o julgamento de uma mesma conduta e, certamente, poderão proferir decisões bastante diferentes sobre ela ${ }^{382}$.

Dessa divergência vemos surgir um outro problema que é o do cumprimento das decisões emanadas (já brevemente discutido no Capítulo 5). É de se supor que, no caso acima, o país A poderia não dar cumprimento a uma decisão do país $\mathrm{B}$, que condenasse o cartel de exportação. Obviamente, a eficácia das decisões e sentenças proferidas no estrangeiro acabam por ficar comprometidas, visto que dependem de atitudes positivas das autoridades de outros países para que possam ser devidamente cumpridas. Aqui, mais uma

liberalidades prejudiciais à concorrência nos EUA, por que poderiam empresas estrangeiras gozar de tal privilégio?” (Direito Antitruste e Relações Internacionais, Curitiba, Juruá, 2001, p. 147 e seguintes).

$381 \quad$ "After a whole century of practice, case law and amending its legislation, American position now is clearer than ever, although even that is not clear enough for practitioners. It is by now well established that the bulk of American antitrust legislation applies to the conduct occurring abroad and producing effects on the US market" (Op. cit., p. 98).

382 "Fundamenta-se na teoria do impacto territorial, conforme a qual o Estado é competente para legislar e conhecer de eventos ocorridos fora de seu território, envolvendo participantes não-nacionais, desde que tais eventos produzam efeitos dentro do território nacional. [...]. A aplicação extraterritorial leva, com certa frequiência, ao concurso de jurisdições com a sujeição de uma determinada prática à aplicação de leis diferentes. Essa situação pode resultar em decisões inconsistentes entre si, na medida em que a proximidade entre política antitruste e política econômica e ideológica forja sistemas culturais de concorrência nacionais muito diversos entre si. Não é incomum, assim, a existência de conflitos no caso de práticas autorizadas pela lei do país em que se consumaram, mas condenadas pelo país em cujo mercado interno são produzidos efeitos anticoncorrenciais" (ANA MARIA NUSDEO, op. cit., p. 162-163). 
vez, encontramos fortes argumentos para aqueles que defendem a adoção de uma "política internacional da concorrência".

Para o caso específico da legislação brasileira, é necessário, antes de qualquer coisa, atentar para o fato de que as normas de direito antitruste são normas de ordem pública. Logo, não podem ser derrogadas por liberalidade dos agentes em prol da de outros países. Essa interpretação deriva da leitura do artigo $2^{\circ}$ da Lei 8884/94, que define o âmbito da lei concorrencial como sendo as práticas cometidas no todo ou em parte no território nacional, ou que nele possam produzir efeitos. Nesses casos, portanto, não há que se falar em lei estrangeira: o máximo que podemos observar é a competência concorrente com a de outra jurisdição.

Em nosso ordenamento, a exemplo do inglês, existem medidas destinadas a bloquear o cumprimento não criterioso de decisões estrangeiras, como, por exemplo, por meio da exigência de homologação das sentenças pelo Superior Tribunal de Justiça - STJ e por meio do disposto no artigo 181 da Constituição Federal, que determina que "o atendimento de requisição de documentos ou informações de natureza comercial, feita por autoridade administrativa ou judiciária estrangeira, a pessoa física ou jurídica residente ou domiciliada no País dependerá de autorização do Poder competente ${ }^{383}$.

\subsubsection{Uma questão específica para os cartéis de exportação}

Vamos agora aplicar esses conceitos de extraterritorialidade ao estudo dos cartéis de exportação. A doutrina nos apresenta algumas dúvidas sobre qual jurisdição e legislação seriam as responsáveis pela sua investigação e julgamento: a do país importador ou a do país exportador. Usualmente se credita ao país que importa os bens a competência, visto ser ele o atingido pela prática do cartel $^{384}$. Analisando-se a legislação brasileira, resta claro que ela é a aplicável a esses casos, tendo em vista que, como se observou, as normas concorrenciais são de ordem pública, dela não podendo se prescindir. Da mesma forma, serão as autoridades brasileiras as competentes para julgar tais práticas. Assim, temos que:

383 “Art. 181. O atendimento de requisição de documento ou informação de natureza comercial, feita por autoridade administrativa ou judiciária estrangeira, a pessoa física ou jurídica residente ou domiciliada no País dependerá de autorização do Poder competente".

384 Nesse sentido as observações de JOHN R. MAGNUS (Op. cit. p. 181). 
i) os cartéis de exportação que venham a ser formados no Brasil (associações para exportação brasileiras) deverão ser analisados tendo em vista a legislação nacional (na dicção do artigo $2^{\circ}$ as "práticas cometidas, no todo ou em parte no território nacional" - o elemento de conexão é a territorialidade). Essa competência é, no mínimo, concorrente;

ii) os cartéis de exportação formados fora do Brasil (associações para exportação estrangeiras) também deverão ser analisados de acordo com a lei concorrencial brasileira (na dicção do artigo $2^{\circ}$ as práticas que "nele produzam ou possam produzir efeitos" elemento de conexão "local de efeito dos atos"). Mais uma vez, a competência é, no mínimo, concorrente;

iii) caso outro ordenamento se declare competente para o julgamento, uma eventual sentença proferida fora do Brasil deveria necessariamente contar com a homologação do Superior Tribunal de Justiça - STJ; e

iv) para qualquer atividade de colaboração investigativa sobre a formação/existência/atuação da associação para exportação seria necessária a autorização da autoridade competente para que se pudesse enviar documentos requisitados ou prestar informações.

Tendo sido estabelecida a competência para análise/julgamento como sendo da lei brasileira, é hora de discutir essa incidência. Comentamos no Capítulo 4 que os países se dividem entre aqueles que: i) não concedem isenções aos cartéis de exportação, ii) concedem isenções implícitas; e iii) os que concedem isenções explícitas. A lei brasileira não possui nenhum dispositivo a cuidar especialmente dos cartéis de exportação, mas eles poderão ser alvo de sua análise, conforme verificamos acima. É de se notar, entretanto, o entendimento esposado por MARGARET C. LEVENSTEIN e VALERIE Y. SUSLOW, segundo as quais o ordenamento brasileiro adotaria isenção implícita aos cartéis de exportação. $^{385}$

A exemplo do Brasil, muitos países não possuem isenções explícitas, mas, apesar disso, os cartéis de exportação existem e não são objeto de processo por parte das

385 Op. cit., p. 819. 
autoridades concorrenciais. Nesse tipo de situação, normalmente, a não utilização da lei concorrencial é justificada pelo fato de não serem constatados efeitos do cartel de exportação dentro do território do país. Ou seja, o direito somente são aplicadas nos casos nos quais se verificam efeitos no território nacional, aos demais, não se aplica a disciplina. Caso se tome essa base de entendimento, as associações para exportação puras estarão imunes à lei concorrencial, enquanto as mistas poderão ser objeto da lei, na medida em que trouxerem prejuízos internos.

Logo, para o enquadramento legal das associações para exportação é necessário que se discuta se as leis concorrenciais serão aplicadas às situações nas quais não se verificam efeitos anticompetitivos dentro do território nacional. Veja-se que o direito concorrencial como implementador de políticas públicas pode ocorrer tanto pela utilização de suas normas como pela abstenção desse processo, conforme a autoridade entender cabível no caso concreto.

\subsection{Válvulas de escape $e^{386}$}

Caso se entenda que a lei antitruste deverá ser aplicada aos cartéis de exportação, o processo ordinário de aplicação do direito terá lugar para que o caso possa ser analisado. Nesse passo, algumas considerações devem ser feitas, especialmente quanto: i) à flexibilização da aplicação desse direito; e ii) aos dispositivos da Lei 8884/94 que seriam aplicáveis aos cartéis de exportação.

O texto frio da lei concorrencial pode resultar, por vezes, em conflitos com os seus propósitos originais. Ou seja, a disciplina da livre concorrência, sem qualquer flexibilização de seus termos, pode trazer em seu bojo efeitos sequer vislumbrados pelo legislador e que podem, até mesmo, comprometer a implementação de determinadas

\footnotetext{
$386 \quad$ "In some cases, the criteria used to determine whether an exception, exemption or exclusion are broad and general, whereas in other cases, the criteria are extremely detailed. In some jurisdictions, the question on whether an exception, exemption or exclusion applies depends on the outcome of a potentially extensive case-by-case or 'rule of reason' analysis. In other, guidelines, regulations or block exemptions are used to give guidance in at least a portion of the cases. In characterizing an exception, exemption and exclusion under national competition law, a basic distinction to be drawn is that between, on the other hand, an exception, exemption or exclusion of a sectoral nature and, on the other hand, those of non-sectoral nature. Sectoral an exception, exemption and exclusion often reflect historical decisions, based on political and economic rationalities that may be specific to the country in question" (WTO, Exception, exemption and exclusion contained in members' national competition legislation. WT/WGTCP/W/172, 6 July 2001).
} 
políticas públicas. Para essas situações, a legislação brasileira, a exemplo de outras, adotou sistema de adequação dos preceitos legislativos ao caso concreto. Caso assim não fosse, a lei se tornaria desconectada da realidade que pretende regular, seja pelo fato de ela ter se alterado a ponto de não mais ser apta a corretamente disciplinar as relações sociais, seja pelo fato de o caso em análise ser uma situação complexa, não prevista pelo legislador. Segundo nos relata PAULA A. FORGIONI, os meios mais utilizados para as "correções de rota" são a aplicação da rule of reason, característica do sistema norte-americano, a concessão de isenções, característica do sistema da União Européia, e o sistema de

autorizações $^{387}$. A estes, podemos somar ainda um outro, que é a utilização de termos vagos no enunciado das normas concorrenciais.

A análise desses mecanismos é de grande importância para este estudo. Isso porque, caso se entenda que a legislação concorrencial deva ser aplicada aos casos nos quais não são verificados efeitos na ordem interna (ou seja, aos cartéis de exportação puros), são esses os mecanismos dos quais dispõe a autoridade antitruste para modular a utilização ao caso concreto.

\subsubsection{Rule of reason}

A rule of reason ou regra da razão foi a forma encontrada pela jurisprudência americana para temperar os rígidos termos do Sherman Antitrust Act. Recordando o que foi visto no Capítulo 6, a Seção 1 do documento traz proibição genérica a quaisquer práticas que possam restringir o comércio. É certo que tal proibição, por muito ampla, acabou por espraiar-se para situações nas quais não haveria qualquer motivo para que tivesse lugar a repressão antitruste. Para contornar essa situação, os tribunais americanos foram construindo ao longo do tempo o entendimento de que as restrições de que fala a lei concorrencial deveriam ser não razoáveis. No mesmo Capítulo, observamos que a Escola de Chicago desempenhou importante papel na transformação da jurisprudência, firmando o entendimento de que estruturas concentradas não eram necessariamente anticompetitivas, mas que poderiam trazer eficiências que as justificassem (superando os preceitos da Escola de Harvard). 
O julgamento sobre aquilo que pode ou não ser considerado "razoável” é cercado de subjetivismo, fruto de ponderação dos julgadores. O método, portanto, abre margem para o ajustamento da norma, sendo a autoridade apta a modulá-la ao caso concreto. $\mathrm{Na}$ tradição norte-americana, as cortes passaram a, no momento do julgamento, fazer um balanço entre eficiências ${ }^{388}$ e malefícios advindos das práticas restritivas ao comércio para, só então, decidir sobre seu futuro - nesse momento, não há dúvida, há claro subjetivismo na utilização da lei, que se presta ao atendimento de um ou outro interesse.

Para este estudo, é interessante verificarmos que os dois grupos de artigos que poderiam ser prestar à análise dos cartéis de exportação comportam as ponderações trazidas pela rule of reason. Vamos analisar cada um deles.

O primeiro, conhecido como controle de estruturas, está estabelecido nos artigos 54 e seguintes da lei concorrencial brasileira e cuida do nascimento de agentes detentores de poder de mercado e que, portanto, poderiam influir no seu normal funcionamento ${ }^{389}$. Por meio desses dispositivos, os agentes são obrigados a notificar à autoridade concorrencial qualquer ato que possa limitar ou prejudicar a livre concorrência ou levar à dominação de

\footnotetext{
388 As principais fontes de eficiências para os atos de concentração são as já estudadas economias de escala e de escopo, o compartilhamento de tecnologias e de investimento em pesquisa e desenvolvimento, as economias nos custos de transação, entre outras. Verificar Capítulo 3. No mesmo sentido: "A SDE, ao demonstrar o caráter genérico do termo eficiência, previsto na alínea c, inciso I, do $\S 1^{\circ}$ do artigo citado, em diversos atos de concentração admitiu diversos tipos de eficiências, tais como: aumento das exportações, melhor distribuição - com racionalização do sistema produtivo decorrente do atendimento dos clientes pelas fábricas mais próximas - com redução de custos, redução dos custos de matéria-prima e decorrentes da utilização de equipamentos mais modernos, hoje ociosos, redução dos custos administrativos, garantia de competitividade em nível internacional, preservação do quadro de funcionários, manutenção da estrutura comercial e respectivas linhas de produto" (JOSE MARCELO MARTINS PROENÇA, Título VII das formas de controle, Capítulo I - Do controle de atos e contratos, cit., p. 391).

389 "Artigo 54. Os atos, sob qualquer forma manifestados, que possam limitar ou de qualquer forma prejudicar a livre concorrência, ou resultar na dominação de mercados relevantes de bens ou serviços, deverão ser submetidos à apreciação do Cade. $\S 1 .^{\circ} \mathrm{O}$ Cade poderá autorizar os atos a que se refere o caput, desde que atendam as seguintes condições: I - tenham por objetivo, cumulada ou alternativamente: a) aumentar a produtividade; b) melhorar a qualidade de bens ou serviço; ou c) propiciar a eficiência e o desenvolvimento tecnológico ou econômico; II - os benefícios decorrentes sejam distribuídos eqüitativamente entre os seus participantes, de um lado, e consumidores ou usuários finais, de outro; III - não impliquem eliminação da concorrência de parte substancial de mercado relevante de bens e serviços; IV sejam observados os limites estritamente necessários para atingir os objetivos visados. $\S 2 .^{\circ}$ Também poderão ser considerados legítimos os atos previstos neste artigo, desde que atendidas pelo menos três das condições previstas nos incisos do parágrafo anterior, quando necessários por motivo preponderantes da economia nacional e do bem comum, e desde que não impliquem prejuízo ao consumidor ou usuário final”.
} 
mercados relevantes. As autoridades são então responsáveis pela análise e julgamento de tais condutas 390 .

A lei é clara ao afirmar textualmente que a autoridade antitruste pode autorizar atos que possam prejudicar a livre concorrência, desde que submetidos às condições trazidas no $\S 1^{\circ}$. A possibilidade de sacrificar a livre concorrência em prol de outros objetivos, como observamos no Capítulo 7, decorre do próprio texto constitucional, que elege (além dela) inúmeros outros princípios e objetivos. Mas aqui, para que não pairem dúvidas, é a própria lei concorrencial (elaborada em uma era de desregulamentação de mercados, nunca é demais lembrar) a firmar que a concorrência poderá ser sacrificada em prol: do aumento da produtividade, da melhoria da qualidade dos bens e serviços, da busca pela eficiência e do desenvolvimento tecnológico e econômico. Há ainda um outro fator de mitigação, estabelecido no $\S 2^{\circ}$, com nítido caráter de política industrial: "Também poderão ser considerados legítimos os atos previstos neste artigo, [...] quando necessários por motivo preponderantes da economia nacional e do bem comum, e desde que não impliquem prejuízo ao consumidor ou usuário final" ${ }^{391}$. Assim, ao avaliar a conveniência ou não da operação, a autoridade não deverá estar preocupada unicamente com o problema da concorrência no mercado e com as possíveis eficiências do ato de concentração.

Da mesma forma como ocorre no caso americano, a avaliação da autoridade antitruste nacional para verificar se um ato de concentração é capaz ou não de trazer, por

$390 \quad$ Dispõe o item 2 da Portaria conjunta 50 da SDE/ SEAE: “O $§ 11^{\text {o }}$ do art. 54 da Lei n. 8.884/94 estabelece o princípio da razoabilidade, ou a regra da razão, como princípio fundamental para o controle dos atos de concentração".

391 Sobre a utilização desse fator de mitigação, observar a crítica de GESNER DE OLIVEIRA: "Notese o risco de que regras genéricas dessa natureza permitam indesejável subordinação do controle de fusões à política industrial. Recomenda-se, assim, que a aplicação do dispositivo seja parcimoniosa a fim de evitar precedente de isenção à Lei 8.884/94. Sua possível aplicação deveria ficar restrita a situações em que, no plano jurídico, envolva a defesa de princípio constitucional de valor equiparável ao princípio da livre concorrência; e, no plano econômico, envolva providências no sentido de prevenir a ocorrência de falhas no mercado relevante ou em mercados conexos" (Concorrência: panorama no Brasil e no mundo, São Paulo, Saraiva, p. 27-28). A despeito de a hipótese nunca ter sido utilizada pelo Conselho Administrativo de Defesa Econômica - CADE, há expectativa de que possa ser utilizado no ato de concentração envolvendo a Braskem e a Quattor. Nas palavras de Ruy Coutinho: "Há possibilidade de ser usada, pela primeira vez, a alegação de interesse nacional para justificar a concentração de mercado brasileiro. Segundo Coutinho, que presidiu a comissão que elaborou a atual lei brasileira antitruste (8.884/94) no governo FHC, o Estado criou uma brecha para viabilizar concentrações de mercado quando houver 'motivo preponderante da economia nacional'. Na história do Cade, essa alegação jamais foi usada. Coutinho lembra que o artigo 54, parágrafos $1^{\circ}$ e $2^{\circ}$ da lei 8.884 , foi criado para essa finalidade. Mas alega que a aplicação é condicionada ao cumprimento de três de seis exigências, entre as quais a divisão equitativa de ganhos obtidos com a concentração entre sócios e consumidores." (AGNALDO BRITO, Braskem-Quattor terá de ser vigiada, diz ex-titular do CADE, disponível em: http://www1.folha.uol.com.br/fsp/dinheiro/fi0601201017.htm, acesso em 06 jan. 2010). 
exemplo, desenvolvimento tecnológico e econômico, é cercada de subjetivismo ${ }^{392}$. Isso não significa, de forma alguma, arbitrariedade. Além dos parâmetros estabelecidos pelo ordenamento jurídico, a norma concorrencial traz outros, como o de que os benefícios sejam distribuídos com os consumidores.

O segundo grupo, estabelecido nos artigos 20 e 21 da lei concorrencial, trata da relação entre os agentes do mercado (conluios em geral) e é genericamente denominado "controle das condutas". O artigo 20 declara como infração à ordem econômica atos que tenham por objeto ou possam de qualquer forma: i) limitar ou falsear a livre concorrência e a livre-iniciativa; ii) levar a dominação de mercado relevante; e iii) levar ao exercício abusivo de posição dominante. $\mathrm{O}$ artigo 21 , por sua vez, nos traz um rol exemplificativo sobre quais seriam as condutas passíveis de enquadramento legal, essas condutas somente serão consideradas anticompetitivas na medida em que configurarem uma das hipóteses do artigo 20 .

Ao contrário da análise de estruturas, de caráter investigativo, esse é um tipo repressivo de estudo, na qual se costuma privilegiar a existência e manutenção da concorrência no mercado. É nítido o intento de inibir o acordo entre concorrentes, o exercício abusivo de poder de mercado, entre outras situações consideradas anticoncorrenciais.

Mas também para esse tipo de averiguação as autoridades antitruste realizam ponderações sobre possíveis justificações e eficiências. Nas palavras de CALIXTO SALOMÃO FILHO: “A referência à hipótese de ilicitude é proposital. É hoje conclusão pacífica e resultado adquirido do Direito Brasileiro o não-tratamento de qualquer conduta como um ilícito per se. Todas estão sujeitas a algum critério de racionalidade que as possa vincular à produção de algum efeito. Essa concepção foi consagrada na lei brasileira pela

392 Nos termos dos itens 11 e 12 da Portaria conjunta 50 da SDE/SEAE: "Os atos de concentração entre empresas podem produzir efeitos positivos e negativos sobre o bem-estar econômico. As concentrações podem, ao diminuir o número de participantes no mercado, facilitar a adoção de condutas anticompetitivas (aumento de preços, redução da qualidade, diminuição da variedade ou redução das inovações). Entretanto, os atos de concentração, na medida em que proporcionem vantagens competitivas para as empresas participantes (economias de escala, economias de escopo e redução dos custos de transação, entre outros), podem também aumentar o bem-estar econômico. 12. Nesse contexto, não é possível definir, em princípio, se concentrações econômicas afetam positiva ou negativamente o bem-estar econômico. Para se saber qual o efeito de um ato de concentração, é necessária a análise específica de cada caso. A compreensão de que os atos de concentração envolvem potencialmente efeitos negativos e positivos e que, por isso, não podem ser per se aprovados ou reprovados, encontra-se consagrada na lei de defesa da concorrência, pela exigência da ponderação das eficiências de cada ato vis-à-vis seus efeitos negativos, nos termos dos $\S \S 1^{\circ}$ e $2^{\circ}$ do art. 54 . 
correlação necessária imposta pelo art. 20 da lei concorrencial brasileira entre as condutas descritas no art. 21 e os efeitos descritos no art. 20”393. Ou seja, que não há que se condenar os acordos entre agentes no mercado per se - apenas na medida em tenham por objeto ou possam limitar, falsear ou de qualquer forma prejudicar a livre concorrência ou a livre-iniciativa é que poderão ser objeto da disciplina antitruste. Caso contrário, não se cogita da aplicação dos seus dispositivos ${ }^{394}$.

A discussão sobre qual método de análise - o controle de estruturas ou de condutas - deveria ser empregado para os cartéis de exportação será realizada a seguir. Por hora, pretendemos que reste clara a possibilidade de utilização da regra da razão para análise dessas estruturas, quer se opte por realizar o estudo pelo artigo 54, quer se opte por realizálo pelo artigo 20 .

\subsubsection{Isenções}

A isenção é outro instrumento destinado ao arrefecimento das normas concorrenciais ao caso concreto. Seu funcionamento, entretanto, é diverso da aplicação da regra da razão: aqui existe um instrumento que impede que determinada conduta seja objeto de sua incidência. Para tanto, os agentes econômicos (ou as próprias autoridades concorrenciais) pleiteiam a isenção de determinada atividade da rígida disciplina das normas concorrenciais.

Essa é a forma encontrada pela União Européia para melhor adequação de sua lei concorrencial às constantes mudanças no mercado. Nas palavras de PAULA A. FORGIONI: "Muitas vezes, as leis antitruste determinam a ilicitude de práticas restritivas

\footnotetext{
393 Direito concorrencial - as condutas, cit., p. 263.

394 Mesmo na tradição norte-americana, em que a condenação dos cartéis é rígida e caracterizada pela condenação per se, encontramos na doutrina o reconhecimento de seu abrandamento. Nas palavras de ROBERT H. BORK: "Yet it is also true that the rule has become somewhat sewed over time, and on occasion produces undesirable results. It can be easily shown that price fixing and market division are beneficial in certain circumstances. The rule should be restated so that it is illegal per se to fix prices or divide markets (or to eliminate rivalry in any other way) only when the restrain is 'naked' - that is, only when the agreement is not ancillary to cooperative productive activity engaged in by the agreeing parties. Only then is the effect of the agreement clearly to restrict output. Many price-fixing and market-division agreements make cooperative productive activity more efficient, and these should be judged, according to the circumstances by the standards applicable to internal growth of firms or by horizontal merger rules" (Op. cit., p. 264).
} 
da concorrência e, ao mesmo tempo, prevêem a possibilidade de sua legitimação mediante a concessão de isenções; admitem, pois, que a prática seja realizada pelos agentes econômicos, sem que lhes seja imposta qualquer sanção. Como já dito, o sistema antitruste europeu adota a metodologia das isenções como principal técnica jurídica para flexibilizar suas normas" ${ }^{395}$. Naquele ordenamento, é usual que setores inteiros da economia desfrutem do mesmo tipo de isenção, não sendo necessário que cada agente isoladamente a pleiteie junto às autoridades. Essa medida torna o sistema de isenções mais justo, na medida em que seus benefícios se estendem a todo o setor produtivo, e não somente àquele agente que obteve a medida.

No Brasil, entendemos ser plenamente viável a concessão de isenções à utilização da lei concorrencial. Nesse sentido, poderíamos ter, por exemplo, a promulgação de uma lei isentando os cartéis de exportação, o que acabaria por trazer para nosso ordenamento uma isenção do tipo explícita.

Numa situação como essa, certamente, não poderíamos falar em antinomia entre o texto da norma concorrencial e o da que concede a isenção. Para esses casos, devemos nos utilizar da regra de hermenêutica que estabelece que a lei específica (a que isenta os cartéis de exportação) deve prevalecer sobre a geral (a própria Lei 8884/94). Veja-se que é o próprio texto da Constituição, ao afirmar existirem outros princípios e objetivos além da livre concorrência e da livre-iniciativa, que dá margem à existência de isenções à aplicação do direito. Logo, o fundamento de validade de tal lei está no próprio texto constitucional e independe de qualquer previsão na norma antitruste ${ }^{396}$.

$395 \quad$ Os fundamentos do Antitruste, cit., p. 215.

396 No resumo de PAULA A. FORGIONI: "Como vimos, a Constituição Federal pressupõe que a livre concorrência deva imperar, de forma geral, nos mercados. Mas também reconhece possível, para atingir os fins maiores positivados no art. 170, o sacrifício total ou parcial da competição entre certos setores, submetendo-os a regramento diverso, que arrefece a pressão concorrencial. Assim, em virtude do texto legal, é posta uma isenção em bloco, que permite prática restritiva da concorrência. Eis nossas isenções: leis específicas autorizadoras de restrições concorrenciais, que prevalecem sobre a regra geral (Lei 8884/94). Vê-se, portanto, que o sistema jurídico brasileiro admite a existência de isenções à Lei Antitruste. Como demonstrado, não é necessária disposição expressa nesse sentido; a legalidade e constitucionalidade das leis específicas autorizadoras de práticas anticoncorrenciais decorrem diretamente da Constituição Federal". Os fundamentos do Antitruste, cit., p. 228. 


\subsubsection{Autorizações}

A terceira forma de arrefecimento se dá por meio do sistema de autorizações. Por ele, uma prática que poderia ser tida como anticompetitiva pela simples leitura do texto de lei passa a não ser assim compreendida, quando analisada pela autoridade antitruste. A concessão das autorizações, no Brasil, ocorre quando a autoridade antitruste permite que determinado ato, potencialmente lesivo à concorrência, seja realizado, tendo em vista as ponderações realizadas no caso concreto, o que se assemelha ao uso da rule of reason.

Para entendermos o seu funcionamento, poderíamos imaginar a seguinte situação: um ato de concentração entre os agentes econômicos é apresentado ao Conselho Administrativo de Defesa Econômica - CADE, dentro da obrigatoriedade estabelecida no artigo $54^{397}$. O índice de concentração a que se chega é muito alto, o que certamente influenciará a dinâmica concorrencial do mercado. Dentro dessas condições, em um primeiro momento, seria de se considerar que a operação não deveria ser aprovada. Entretanto, outras considerações devem ser levadas em conta pela autoridade: trata-se de empresas nacionais, que empregam um grande número de funcionários, e que dependem das economias de escala e escopo advindas do ato de concentração para continuarem competitivas no mercado. Esses fatores certamente deverão ser sopesados na averiguação da operação. Ao final, tendo em vista esses fatores de mitigação, o ato de concentração poderá ser autorizado pela autoridade antitruste, que poderá, até mesmo, elencar algumas condições para que isso ocorra (os chamados compromissos de desempenho, estabelecidos no artigo 58 da lei concorrencial) ${ }^{398}$.

Existem parâmetros legais para a concessão dessas autorizações. No caso dos atos de concentração, como observamos, os limites, ainda que fluidos, estão elencados no $\S 1^{\circ}$ do artigo 54, impedindo que se possa falar em arbitrariedade em sua concessão.

$397 \quad \mathrm{O} \S 3^{\circ}$ do artigo 54 cria presunção relativa de que as operações entre agentes econômicos que atinjam $20 \%$ de concentração no mercado ou entre agentes com faturamento superior a R $\$ 4.000 .000,00$ seriam infrativas à ordem econômica, sendo obrigatória a sua apresentação ao Sistema Brasileiro de Defesa da Concorrência.

398 “A legislação brasileira abraçou o sistema da concorrência-meio. Evidente, pois, que, em prejuízo da concorrência como fim, esta poderá ser sacrificada para a tutela de outros interesses, também protegidos em nível constitucional, como a defesa do consumidor. Assim é que é possível a autorização, pelo CADE, de um ato de concentração horizontal de empresas que inevitavelmente sacrificará a concorrência, dado os benefícios que ele poderá colacionar aos consumidores, como a redução dos preços, o aumento das eficiências em termos qualitativos e quantitativos dos produtos etc" (JOSÉ MARCELO MARTINS PROENÇA, Título VII das formas de controle, Capítulo I - Do controle de atos e contratos, cit., p. 374). 
Uma vez tendo sido a operação autorizada pelo Conselho Administrativo de Defesa Econômica - CADE, para que os agentes não fiquem à mercê de alterações no entendimento da autarquia, não poderá a sua decisão ser objeto de revisão, a menos que se constatem erros, que justifiquem o desfazimento da operação ou o não cumprimento das obrigações impostas quando da aprovação do ato.

Essas autorizações poderiam, sem qualquer sombra de dúvidas, serem concedidas a cartéis de exportação que submetessem suas operações ao escrutínio da autoridade concorrencial brasileira.

\subsubsection{Utilização de termos fluidos}

Um último mecanismo que iremos estudar para a adequação das normas concorrenciais à complicada realidade que disciplinam é a utilização de termos vagos.

As leis concorrenciais são de âmbito geral, prestando-se a disciplinar as relações de forma genérica. Para que a aplicação do direito possa ser amoldada aos fins a que se destina, é possível o emprego de termos fluidos, de conteúdo impreciso, como os conceitos de "mercado relevante", "domínio de mercado", "eficiência", "desenvolvimento" (disposto no artigo 20 da lei). A utilização dessas palavras em nada revela imprecisão do legislador, mas sim o fato de que a vivacidade do dia-a-dia econômico é fator que demanda normas de direito concorrencial temperadas pelo ambiente social, político e econômico do país. Em um momento de crise mundial e de grande recessão, por exemplo, a noção de desenvolvimento pode ser bastante diversa daquela em voga em um momento de estabilidade econômica. Para que a autoridade antitruste possa levar esses fatores em consideração quando do julgamento do caso concreto, não é necessária a alteração da lei, mas simplesmente a existência desse texto fluido, que viabiliza a perenidade e atualidade da legislação.

No momento em que a autoridade antitruste define, delimita a extensão que deve ser dada a esses termos, revela-se a dimensão política da aplicação do direito concorrencial - esse é um aspecto eminentemente político e que permite que as autoridades da concorrência a utilizem para implementar políticas públicas. No caso brasileiro, a competência para a interpretação dessas normas é do Conselho Administrativo de Defesa 
Econômica - CADE, da Secretaria de Direito Econômico - SDE e do Poder Judiciário, a quem cabe rever a decisão dos dois entes anteriormente citados ${ }^{399}$. Como se afirmou acima, a busca pela implementação dessas políticas públicas deve estar dentro da pauta de interpretação previamente estabelecida pela Constituição e dentro da política de concorrência, sob pena de adentrarmos no campo da arbitrariedade ${ }^{400}$.

Para o caso dos cartéis de exportação, a aplicação de um determinado termo é especialmente importante: trata-se da delimitação do "mercado relevante ${ }^{401}$ ". Caso, na análise de uma associação para exportação pura, consideremos o mercado relevante como sendo unicamente o mercado nacional, não teríamos falar em utilização da lei concorrencial a esses casos, visto não existirem quaisquer efeitos advindos da utilização

$399 \quad$ "Cabe lembrar que a verificação de que as regras antitruste contêm freqüentes conceitos jurídicos indeterminados remete a outras questões. Em primeiro lugar, a quem cabe a interpretação? E, em segundo, trata-se a competência para o preenchimento desses termos, de ato discricionário ou vinculado? A primeira questão há de ser respondida com base nas disposições de sistema legais individualizados. Assim, no Brasil, são competentes para sua definição o CADE e, em determinadas situações, a Secretaria de Direito Econômico (SDE). Apesar de dependente da resposta à segunda questão, podemos afirmar que o poder judiciário também tem competência para esse preenchimento naqueles casos em que os atos do CADE forem objeto de questionamento em juízo. A segunda questão é de resposta mais difícil, e não consensual. No entanto, a tendência predominante na doutrina é considerar tratar-se essa interpretação de ato vinculado. Isso porque o intérprete não formulará juízo de legalidade, pois sua interpretação terá de se dar de acordo com os demais princípios e regras estabelecidos na legislação e no ordenamento jurídico como um todo. Conforme aponta Eros Grau, 'no Estado de Direito, qualquer agente público somente deterá competência para a prática de atos discricionários - isto é, exercitando as margens de liberdade de atuação fora dos quadrantes da legalidade - quando a norma jurídica válida a ele atribuir a formulação de juízo de oportunidade'. Esse entendimento não deve levar à convicção de que, tratando-se de um ato vinculado, exista apenas uma resposta certa à interpretação desses conceitos. Isso porque essa interpretação refere-se mais a uma lógica de preferência do que de consequência, à medida que não se destina à perseguição da verdade, mas de uma solução satisfatória e juridicamente plausível, a partir de elementos fáticos da questão ser solucionada - e no caso da aplicação das regras antitruste, deve-se considerar, com a utilização de teorias econômicas variadas. O caráter de verdadeira ou falsa no contexto da interpretação jurídica é definido pela coerência do seu embasamento no sistema. A possibilidade de mais de uma resposta correta reforça o mecanismo flexibilizador, permitindo a integração de diferentes interesses e objetivos de política econômica, obviamente dentro dos limites de abertura dos conceitos jurídicos indeterminados utilizados pela lei" (ANA MARIA NUSDEO, op. cit., p. 72 e 73). Ainda sobre o tema, consultar CALIXTO SALOMÂO FILHO, Direito concorrencial - as condutas, cit., p. 145.

$400 \quad$ "Está bastante claro que as normas antitruste são um sistema de princípios, como bem salientou Bernini, e se os abandonarmos como pautas interpretativas, aí sim estaremos no mais puro campo da arbitrariedade, do 'pragmatismo caótico'. Mas, para que se possa lançar mãos dos princípios, especialmente quanto tratamos de normas de tutela da livre concorrência, é necessário que eles sejam identificados. O superamento do subjetivismo, como nos lembra Esser, exige o conhecimento do processo de política do direito, em medida suficiente para entender a motivação da decisão e suas conseqüências. Em outras palavras, para que seja proporcionado um certo grau de segurança e previsibilidade, exige-se a definição da política da concorrência, por parte das autoridades competentes" (PAULA A. FORGIONI, Os fundamentos do Antitruste, cit., p. 311 e 312).

401 Mercado relevante, que pode ser subdividido em geográfico e o de produto, nada mais é do que a delimitação do espaço e dos produtos nos quais ocorre a dinâmica concorrencial. Para aprofundamentos sobre o conturbado conceito, indispensável a obra de CALIXTO SALOMÂO FILHO. 
desses instrumentos dentro do território brasileiro. Por outro lado, caso o mercado relevante seja o mundial, os efeitos do cartel de exportação poderão ser verificados, o que levaria à incidência das normas concorrenciais. Veja-se, portanto, que a decisão é tomada tendo em vista como o mercado relevante é delimitado.

A conclusão desta parte do trabalho é de que todos esses mecanismos de adequação da norma concorrencial ao caso concreto ora estudados (rule of reason, isenções, autorizações e emprego de termos vagos) são aplicáveis aos cartéis de exportação e permitem que as autoridades antitruste pautem a sua análise pelos princípios estabelecidos na Constituição Federal e pelas políticas públicas.

\subsection{A disciplina dos cartéis}

Verificamos no item acima que, caso se entendesse que a lei concorrencial brasileira devesse ser aplicada aos cartéis de exportação, existiriam maneiras de flexibilizar essa utilização, adequando-a às peculiaridades dessa modalidade de acordo entre concorrentes (estudadas no Capítulo 4). É chegado o momento agora de verificar quais dispositivos seriam aplicáveis às associações para exportação.

As duas categorias de proteção trazidas pela legislação concorrencial pátria (controle de condutas e controle de estruturas) não são estanques, podendo as autoridades antitruste se valer de uma ou de outra a depender da forma como pretendem avaliar a conduta dos agentes.

Sob uma visão mais tradicional, poderíamos supor que se escolheria analisar os cartéis de exportação nos termos dos artigos 20 e 21 da lei concorrencial, que cuidam das condutas dos agentes no mercado e, especialmente, dos cartéis. Ocorre que, conforme já expusemos no Capítulo 4, os cartéis de exportação não devem ser vistos como meros cartéis clássicos. Por todas as diferenças assinaladas, deveria ser garantido a esse tipo de estrutura uma análise que desse ênfase aos benefícios/eficiências que podem resultar de sua utilização. Nesse aspecto, CALIXTO SALOMÃO FILHO afirma que os acordos entre concorrentes podem ser analisados pela óptica da concentração de estruturas no mercado. 
E que os dispositivos do artigo 54 devem ser utilizados como regra da razão para a análise das estruturas dos cartéis ${ }^{402}$.

Embora possa parecer de menor relevância, a opção pelo emprego do controle de condutas ou de estruturas revela diferentes formas de entender a atividade conjunta entre concorrentes. Caso optemos pelos artigos 20 e 21, o foco estará no repudio a condutas anticoncorrenciais no mercado, existindo maior ênfase em sua repressão e coibição. $\mathrm{O}$ controle de estruturas, por outro lado, costuma abarcar estudos menos voltados à repressão, e mais focado na possibilidade de surgimento de novas estruturas e de como se daria a nova dinâmica de mercado. Seria dada ênfase às eficiências e a outros objetivos buscados pelas leis concorrenciais ${ }^{403}$. O caso dos cartéis ilustra como as autoridades podem optar por uma ou outra forma de análise, sendo a escolha muitas vezes influenciada por critérios

402 "Essa relação simbiótica entre controle de estruturas e controle dos comportamentos se faz sentir, com particular intensidade, com respeito aos cartéis. Relativamente a eles, é difícil determinar em que sede controle das estruturas ou dos comportamentos - podem receber tratamento mais adequado. Nos EUA, tradicionalmente, os cartéis sempre foram disciplinados entre os comportamentos anticoncorrenciais, estando, inclusive, sujeitos durante muito tempo a uma rígida disciplina de ilícitos per se. A Europa, ao contrário, seguindo a tradição germânica, analisa os acordos de cooperação do tipo cartel como estruturas que devem ser previamente controladas. Note-se, no entanto, que ali levantam-se sérias dúvidas sobre uma eficácia de tal disciplina. A pratica tem demonstrado ser impossível o controle preventivo de todos os acordos de cooperação e as autoridades têm sido tolerantes com relação a acordos não levados ao conhecimento dos órgãos de concorrência (tanto na Alemanha como na UE). Utilizam-se, então, as regras que dispõem sobre a aprovação dos referidos acordos como critério para avaliar, posteriormente, a licitude dos comportamentos dos competidores havidos em função desse acordo. No Direito Brasileiro o mesmo dilema se faz sentir. Os acordos entre concorrentes são claramente sujeitos à disciplina das estruturas por força do art. 54 da lei concorrencial. Em virtude da total ausência de regulamentação estatal clara a dispor a respeito dos referidos acordos, o que se pode esperar é que o art. 54 seja utilizado como regra da razão para a análise comportamental dos acordos entre concorrentes" (CALIXTO SALOMÃO FILHO, Direito concorrencial - as condutas, cit., p. 20).

403 "Quanto ao sistema que reprime as práticas restritivas, regulado pelos artigos 20 e seguintes da Lei n. 8.884/94, há tendência de privilegiar uma noção estrutural de concorrência e de avaliar esta como um bem em si mesmo - concorrência-fim - também chamada de teoria da concorrência-condição, razão pela qual se estabeleceu uma proibição genérica, e a priori, de todos os acordos e práticas suscetíveis de atingirem a estrutura concorrencial do mercado, combatendo-se, portanto, a concentração por meio da proibição das práticas que a ela possam conduzir. [...]. O segundo sistema tende a privilegiar os comportamentos efetivos dos agentes econômicos. A concorrência é dada como um bem entre outros e não um bem em si mesmo, podendo ser sacrificada em favor de outros bens, também protegidos pela legislação. Trata-se da concorrência-meio, e, como tal, pode, em certas circunstâncias, ser afastada em nome da proteção de outros interesses ou da realização de outros fins socialmente relevantes. Daí que esse sistema não pretenda, em abstrato, combater os acordos, oligopólios, monopólios ou quaisquer outros fatores de domínio de mercado nos quais venha a se manifestar a concepção econômica. Tal sistema, na verdade, preocupa-se apenas em reprimir tais atos quando, por particulares condicionalismos, se revelem prejudiciais ao interesse geral, declarando ilícitos os acordos ou práticas que produzam efeitos negativos na concorrência, não justificados por outras razões. Tal sistema, no que toca ao controle e técnica de proibição, na observação do direito comparado, tende a adotar um controle prévio das práticas restritivas por um órgão administrativo ou jurisdicional que poderá declarar nula ou não determinada prática. Entretanto, a legislação atualmente vigente no Brasil possibilita, também para tal sistema de controle, a verificação a posteriori da prática do ato" (JOSÉ MARCELO MARTINS PROENÇA, Título VII das formas de controle, Capítulo I - Do controle de atos e contratos, cit., p. 373 e 374). 
ideológicos. Assim, é notória a divergência existente entre a tradição americana, bastante arredia a acordos entre concorrentes, e que costuma utilizar o controle de condutas para examinar os cartéis, e a tradição européia, que privilegia o método controle de estruturas para atingir o mesmo fim. Logo, não há dúvidas de que nossa preferência é por uma análise que leve em conta o controle de estruturas.

Vamos iniciar a análise pelo controle de condutas. Os artigos 20 e 21 da Lei 8884/94 tratam, de forma genérica, do cartel tradicional (especialmente o inciso I do artigo 21, que dispõe: "fixar ou praticar, em acordo com concorrente, sob qualquer forma, preços e condições de venda de bens ou de prestação de serviços"). Não cuidou o legislador de outros acordos entre concorrentes, que, como já vimos, devem possuir disciplina diferenciada, como os cartéis de crise ou os cartéis de exportação. A autoridade antitruste deverá, portanto, na análise do caso concreto fazer a distinção entre os mais variados tipos de acordo entre concorrentes.

Esse problema pode ser resolvido com a própria interpretação sistemática da lei e dos princípios constitucionais. Verificamos que os acordos entre concorrentes, para serem objetos da lei antitruste brasileira, devem necessariamente: i) prejudicar a livre concorrência ou a livre-iniciativa; ii) levar à dominação de mercados relevantes; iii) levar ao aumento arbitrário de lucros ou iv) exercer de forma abusiva posição dominante. Repise-se, por muito importante: em quaisquer outras situações, que não as elencadas, não há que se falar em incidência da disciplina concorrencial ${ }^{404}$.

Pois bem. Um cartel de exportação presta-se a estabelecer melhores condições para que os produtores nacionais coloquem seus produtos no exterior. Sua atividade (se considerarmos os cartéis de exportação puros): i) não terá o condão de prejudicar a livre concorrência nem a livre-iniciativa no mercado brasileiro; ii) não levará à dominação de qualquer mercado relevante interno; iii) não terá qualquer efeito sobre os preços praticados no Brasil e, por fim, iv) não permitirá que qualquer agente exerça abusivamente sua

\footnotetext{
$404 \quad$ "Feitos esses esclarecimentos, podemos dizer que na tutela da livre-iniciativa (e, portanto, da livre concorrência), encontra-se um dos principais parâmetros da nossa Lei Antitruste e a pauta de sua interpretação. Dessa forma, os acordos entre empresas são vedados na media em que configuram um entrave à livre-iniciativa ou à livre concorrência. Ou seja, é no prejuízo à livre concorrência e à livre-iniciativa que se encontra o caráter ilícito de qualquer prática concertada" (PAULA A. FORGIONI, Os fundamentos do Antitruste, cit., p. 274-275).
} 
posição dominante dentro do mercado nacional. É de se convir, portanto, que um cartel de exportação puro não está sujeito à incidência do artigo 20 da lei concorrencial brasileira ${ }^{405}$.

Isso ocorre a menos que o intérprete entenda que o mercado relevante a ser considerado em tal análise não seja o mercado nacional, mas sim o mundial (essa discussão já foi travada ao longo do Capítulo 5 e também quando do estudo dos "termos vagos"). Com a devida vênia, entendemos que tal interpretação não está em linha com os princípios e objetivos traçados pela Constituição Federal (que traz objetivos nacionais a serem alcançados pela ordem econômica) e com os limites para a lei concorrencial, estatuídos no artigo $2^{\circ}$ da Lei 8884/94.

Quanto aos cartéis de exportação mistos, entendemos que podem sim ser objeto da lei concorrencial. Em se tratando do controle de condutas, seria necessário que a análise não fosse feita com vistas a condenar um tipo comum de cartel, mas que se levassem em consideração os benefícios, eficiências e malefícios dele advindos.

Em se tratando do controle de estruturas, um quadro bastante diverso se apresenta. Aqui, não há o objetivo de condenação da prática dos agentes, mas a verificação dos benefícios e malefícios que determinada estrutura pode trazer ao mercado, abrindo-se espaço para considerações de ordem econômica, social e mesmo de política econômica ${ }^{406}$. Nas palavras de PAULA A. FORGIONI: "Tanto no Brasil quanto na Europa, a disciplina das concentrações não pode ser encarada de forma dissociada da política econômica, o que faz com que seu controle assuma, também, caráter instrumental”407.

Nossa lei antitruste, conforme também já asseverado, confere condições para que seja autorizada a formação de estruturas que possam afetar a livre concorrência, desde que

$405 \quad$ "Trazendo a tradicional definição de cartel para o contexto da Lei 8.884, de 1994, devemos concluir que se um acordo não restringe e livre concorrência ou não acarreta a incidência de qualquer inciso do art. 20 da Lei 8.884, não há que se falar na existência de cartel pois a associação não traz, em si, qualquer efeito anticompetitivo que interesse à proteção da ordem econômica". (PAULA A. FORGIONI, Os fundamentos do Antitruste, cit., p. 399).

406 " “...] o fato de os atos de concentração produzirem, frequentemente, efeitos positivos à economia torna mais complexa sua regulação jurídica. De fato, se fossem predominantes seus efeitos nocivos as normas antitruste poderiam prever uma proibição absoluta. No entanto, em decorrência da sua utilidade e imprescindibilidade à economia de mercado, as operações de concentração exigem uma apreciação caso a caso, no qual os efeitos negativos à concorrência e os benéficos à economia como um todo sejam devidamente balanceados, segundo os critérios estabelecidos pelas diferentes legislações de proteção à concorrência" (ANA MARIA NUSDEO, op. cit., p. 26-27).

407

Os fundamentos do Antitruste, cit., p. 480. 
apresentem fatores que as justifiquem. Mesmo porque, veja-se só, um ato de concentração é uma operação da qual resulta permanentemente uma única estrutura no mercado, quando antes havia ao menos duas. É, nesse aspecto, uma concentração muito mais lesiva dos que os cartéis, tendo em vista que o acordo entre concorrentes pode ser desfeito a qualquer tempo. É dentro dessa óptica - de contrabalancear prós e contra que devemos analisar os cartéis de exportação ${ }^{408}$.

Dentro dessa lógica de balanceamento, BRENDAN J. SWEENEY nos traz algumas ponderações a serem feitas no caso específico dos cartéis de exportação: "Export cartels may reduce or enhance consumer and aggregate welfare depending on the circumstances. Where the cartel is comprised of small to medium-sized businesses and its aim is to increase the value of exports by reducing costs or improving products, the cartel is likely to be welfare-enhancing in both the exporting and the importing state. These cartels present no global competition problem. Where the cartel is between firms with a large share of the foreign market the cartel has the capacity to extract supra-competitive benefits in the importing state. The importing state suffers a loss of consumer welfare without any offsetting increases in producer welfare" 409 .

Ademais, para os estudos dos atos de concentração, não podemos negligenciar a importância das descobertas econômicas para o estímulo da competitividade das empresas. Não restam dúvidas de que os conhecimentos trazidos por esses conceitos devem ser levados em conta quando da tomada de decisão sobre a utilização dos cartéis de exportação. Como se observou no Capítulo 3, as economias de escala e de escopo podem ser importantes aspectos na determinação dos custos de produção: uma produção mais custosa ou ineficiente pode retirar a empresa do mercado, em prol de competidores mais eficazes. Mas não são apenas essas teorias a subsidiarem a escolha por atitudes de cooperação entre os players.

\footnotetext{
408 "Juridicamente podemos distinguir entre: a) cartéis ou consórcios que têm diretamente por fim a disciplina da concorrência recíproca entre empreendedores que participem do controle, eventualmente concentrando num órgão comum (que por seu turno pode se constituir como sociedade autônoma) a colocação no mercado do produto consorciado (ou a sua aquisição); b) contratos que, embora visando diretamente um fim diverso, visam, entretanto, indiretamente, uma limitação da concorrência: tal é, às vezes, o caso dos contratos de licença de patentes, dos de locação de estabelecimentos comerciais (enquanto destarte a direção da exploração industrial passa a pertencer apenas a uma sociedade, embora os diversos estabelecimentos continuem pertencendo a sujeitos jurídicos diversos); da constituição de uma sociedade holding (que por seu turno limita à sua atividade ao controle sobre demais sociedades cujas ações possui e que destarte ficam sujeitas a uma direção única)" (TULLIO ASCARELLI, Ensaios e Pareceres, cit., p. 224).
} 
As teorias de redes de empresas têm ocupado grande parte das discussões da economia industrial. Os estudos tratam da necessidade de avaliar a competição tendo como foco não a empresa em sua individualidade, mas levando em conta a interdependência existente entre os mais variados players. Em meio a essas discussões encontramos temas como a cooperação entre as agentes, os processos de terceirização, a união de competidores com vista à inovação (alianças estratégicas), entre outros. Todos esses elementos referem-se à maleabilidade e flexibilidade necessárias para a atuação das empresas, especialmente quando tratamos da concorrência em nível internacional ${ }^{410}$.

Quando aos cartéis puros, acreditamos que não restem muitos pontos a serem discutidos. Tendo em vista que as suas atividades não poderão limitar ou de qualquer forma prejudicar a livre concorrência do mercado interno, resultar em dominação do mercado relevante nacional, não acreditamos que a Lei 8884/94 deva regular a formação de tal tipo de associação. Já com relação aos mistos, deveria ter lugar uma análise de concentração sem qualquer preconceito associado ao fato de se tratar de cartel para $\operatorname{exportação~}^{411}$.

Esse tipo de diferenciação no tratamento dos cartéis de exportação e dos cartéis clássicos também é observado em outros ordenamentos, como nos informa a Organização para a Cooperação e Desenvolvimento Econômico - OCDE: "In practically all of the 19 analyzed above 'pure' export cartels are subject to a less strict control than domestic cartels. On the other hand, 'mixed' export cartels, to the extend that they restrain domestic competition or have other relevant domestic effects, are normally subject to the same rules as 'pure' domestic cartels, but there may be special exemption rules where the domestic restraint or effect is ancillary to the restraint in export trade (e.g. in Germany, Japan and United Kingdom) or such domestic restraints or effects are less likely to be regarded as being against the public interest. All 9 legislations based on the prohibition principle (France, Canada, Germany, Japan, Spain, United Kingdom (1), United States, EEC and CSC) have special rules for export cartels which exempt 'pure' export cartels either partly or entirely from the control applied to domestic cartels" $" 412$.

\footnotetext{
410 Para estudos detalhados, consultar DAVID KUPFER e LIA HASENCLEVER, op. cit.

411 A esse respeito, CALIXTO SALOMÃO FILHO, Direito concorrencial - as condutas, cit., p. 228.

412 OCDE, op. cit., p. 22.
} 


\subsection{A experiência brasileira}

$\mathrm{Na}$ jurisprudência brasileira não é farta em julgamentos sobre os cartéis de exportação. Não podemos deixar de mencionar, entretanto, um ato de concentração que, a despeito de se tratar de um cartel de crise, pode ilustrar a forma pela qual o Conselho Administrativo de Defesa Econômica - CADE se posicionou sobre algumas questões de relevância para o estudo. Trata-se do caso da Brasil Álcool S.A. ${ }^{413}$.

Segundo informações que nos são trazidas pelo relatório do Conselheiro Relator JOÃO BOSCO LEOPOLDINO DA FONSECA, em 02 de fevereiro de 1999 foi constituída, por meio de assembléia geral realizada na Bolsa de Mercadorias e Futuros, a Brasil-Álcool S/A, sendo 84 as empresas constituintes. O objeto social da empresa era o de comercializar, no mercado nacional e internacional, álcool carburante anidro e hidratado e de açúcar por período de 3 anos. As justificativas para o ato de concentração foram as seguintes: "Segundo o arrazoado apresentado pelas Requerentes, os objetivos da BrasilÁlcool, durante sua vigência, são: canalizar esforços dos produtores para escoar o estoque de excedentes do mercado brasileiro de álcool combustível (anidro e hidratado), mediante a conquista de novos mercados e certeiro aumento da demanda nacional, mediante medidas governamentais; promover o equilíbrio entre oferta e demanda no mercado nacional do álcool combustível, mediante remanejamento dos estoques excedentes da produção; evitar um colapso maior do que o já vivido pelo setor, o que poderia resultar no desaparecimento desse mercado estratégico para o país e no conseqüente desperdício de todos os investimentos públicos despendidos com o setor sucroalcooleiro”.

A autarquia entendeu o pleito como um pedido para que fosse autorizada a constituição de um cartel de crise, justificado principalmente por duas questões: as eficiências que poderiam ser geradas e os motivos de preponderante interesse nacional ${ }^{414}$.

413 Ato de Concentração no $08012.002315 / 99-50$, julgado em 08 de novembro de 2000 pelo Conselho Administrativo de Defesa Econômica - CADE.

414 Assim enumeradas no relatório do Conselheiro Relator: "As Requerentes alicerçam a operação com base em dois pilares: eficiência promovidas pela operação e motivos de preponderante interesse nacional. Eficiência Alegadas Pelas Requerentes

1 - A operação implicará na conquista de mercados internacionais, mediante comercialização do excedente da oferta de álcool, o que, além de ser motivo relevante por si mesmo, restabelecerá, ademais, o equilíbrio entre demanda e oferta no mercado nacional (fls. 13 e 14): “... o principal objetivo da Brasil-Álcool S.A. é 
canalizar esforços dos produtores para escoar esse estoque excedente através da conquista de novos mercados no exterior, aproveitando-se toda a sinergia advinda da representatividade da maior parte do setor para se alcançar a quebra de barreiras decorrentes das extremas regulamentações existentes nos diversos países...”.

“...a conquista de novos mercados já representa uma grande eficiência, que por si só já justifica a aprovação do presente ato...”.

2 - $\mathrm{O}$ ato apresenta argumentos que o justificam mediante interpretação a contrario sensu dos incisos do $\S 1^{\circ}$ do art. 54 da Lei $\mathrm{n}^{\circ}$ 8.884/94, uma vez que pretende (fl.14,15 e 16): Aumento da produtividade: evitar a diminuição da produtividade do setor, podendo, inclusive, retomar o crescimento da oferta; Melhoria da qualidade de bens ou serviços: desestimular a atividade de distribuidoras inidôneas que, além de oferecerem o produto aquém do padrão de qualidade originário, forçam o preço de oferta dos produtores para baixo, pois competem em condições desiguais com as distribuidoras idôneas, mediante sonegação de impostos, adulteração do produto, entre outras arbitrariedades; Propiciar o desenvolvimento tecnológico e econômico: aumentar o preço de venda do álcool que, nos níveis atuais acaba por inviabilizar investimentos em eficiência e desenvolvimento tecnológico. Repartir os benefícios com os consumidores: evitar que os consumidores sejam prejudicados pelo uso de combustível de má qualidade, oferecido por distribuidoras inidôneas, assim como sejam impossibilitados de utilizar seus veículos pelo desaparecimento do álcool combustível, com o provável colapso do setor, caso não seja aprovado o ato. Não implicar em limitação de parte substancial da concorrência no mercado relevante: manter grande parte da produção sob poder originário das empresas formadoras da Brasil-Álcool. Observar os limites estritamente necessários ao atendimento dos objetivos pretendidos: restringir-se aos limites necessários para atingir as eficiência supracitadas.

- Interesse nacional e bem comum:

3 - As Requerentes alegam que o ato atenderá as determinações do $§ 2^{\circ}$ do art. 54 da Lei 8.884/94, dado que, além de preencher todos os requisitos do $\S 1^{\circ}$ do mesmo artigo, trata-se também de motivo preponderante para o interesse nacional e o bem comum, uma vez que: O setor sucroalcooleiro é responsável por um número relevante de empregos em todo o Brasil: “... o setor, a reboque de sua existência, mantém em torno de 1 milhão de empregos diretos (representando mais de $40 \%$ dos empregados rurais só no Estado de São Paulo)" (fl. 16).

- O setor responde uma enorme arrecadação das administrações públicas: “...movimenta recursos da ordem de mais de R\$11,92 bilhões, sendo responsável pela arrecadação de mais de 2,95 bilhões em impostos;” (fl. 17).

- Existem mais de 4 milhões de veículos movidos a álcool que correm o risco de perderem suas funções, caso haja um colapso do setor: "Quanto aos consumidores finais, proprietários de automóveis movidos a álcool (em torno de 4 milhões), estes não correrão o risco de ficar impossibilitados de utilizar seus veículos pelo desabastecimento ou mesmo com o desaparecimento total do combustível, se houver o colapso do setor, movido pela situação atual que inviabiliza a produção de álcool.” (fl. 17).

- Importância tecnológica e estratégica do álcool combustível como fonte de energia alternativa para o petróleo, além de outras destinações que têm sido estudadas: “...é notória a importância estratégica que essa grande capacidade instalada de álcool combustível representa para o país, importância essa que independe do atual excesso de oferta, vez que poderão advir novas crises mundiais no abastecimento do petróleo, situações essas em que o país poderá se valer de sua autonomia energética ... e de redução geral na dependência de combustíveis de fontes não renováveis, como justamente é o caso do petróleo". (fl. 17).

- Formação de estoques estratégicos do combustível, o que inclusive determinado por lei - Lei 8.176/91 e Decreto 238/91: "Registre-se, finalmente, que a formação de estoques de combustível como possibilitado pela BRASIL-ÁLCOOL é, como já se referiu, uma questão estratégica para o país, já por definição legal” (fl. 17).

- Preservação dos avanços tecnológicos conquistados pelo Pró-Álcool: “ Trata-se de uma visão de longo prazo, exigida pela construção de uma matriz energética que vislumbre alternativas para as fontes não renováveis de energia, tendo sido o Programa Brasileiro do Álcool inovador nesse sentido e representa hoje 


\section{O Conselheiro Relator, ao longo de seu extenso voto faz inúmeras referências às interações}

existentes entre os valores políticos e a aplicação do direito da concorrência que existiam no caso concreto, inclusive sobre a política econômica que por muito tempo foi aplicada pelo governo ao setor da cana-de-açúcar. ${ }^{415}$.

avanços tecnológicos não despreziveis que vão da agricultura à indústria e que poderão se perder pela desorganização conjuntural do setor..." (fl.17-18).

- Outras justificativas alegadas:

4 - Além dos motivos acima detalhados, as requerentes alegam que: A operação é o único meio que possuem de continuarem operando, visto que o mercado encontra-se ameaçado de desaparecimento, devido ao fato de estarem operando a baixo de seus custos: “...produtores... encontraram como única alternativa emergencial para sobrevivência do setor, congelar uma parte dos estoques das últimas safras direcionando-a para novas oportunidades de exportação, evitando-se um colapso em setor econômico estratégico e social de tanta importância"(fl. 12). "... a contribuição advinda desse ato para a preservação e sobrevivência do setor sucroalcooleiro já é um motivo preponderante...”. (fl. 16). “...com a retirada dos excedentes, restabelecer, o quanto possível, o equilíbrio entre a demanda e a oferta no mercado de álcool combustível, através da recuperação dos preços em níveis minimamente razoáveis para sobrevivência do setor" (fl.16).

- Negociar em condições mais igualitárias com os distribuidores, visto que os produtores são pulverizados, ao passo que o mercado de distribuidores é um oligopsônio, e que, por modo dessa estrutura, pressiona o preço de venda dos produtores para baixos níveis, incompatíveis com os custos de produção: “... os mais de 250 produtores de álcool combustível ...(em sua grande parte descapitalizados e com excessivos estoques) passaram a negociar a quase totalidade de sua produção (e o pior, também os estoques acumulados decorrentes do excesso de sua produção ), basicamente com apenas seis grandes distribuidoras, ou seja, Shell, Esso, Texaco, Ipiranga/Atlantic, BR e São Paulo/Agip, operando-se a transferência do sistema administrado pelo governo para um mercado oligopsônico privado (distribuidores principais, responsáveis pela compra de $75 \%$ do álcool combustível)..." (fl.11).

- A operação é apontada como recurso temporário para uma crise conjuntural que se demonstra em vias de término, coincidindo, este, com o prazo estipulado para a vigência do empreendimento. A recuperação da demanda se daria, segundo as Requerentes, pela ampliação dos incentivos públicos à demanda por álcool anidro, bem como pelo crescimento natural da frota de veículos nacionais movidos a álcool."

415 A título de exemplo escolhemos o seguinte trecho, no qual também é colacionado o entendimento de um dos patronos do ato de concentração: "Não se podem desconhecer as profundas implicações do chamado Programa do Álcool com as crises de energia geradas pelo cartel do petróleo, com as políticas alternativas de energia enfatizadas pelo governo federal e com as políticas de emprego, ou mesmo de trabalho. Em pronunciamento perante a Comissão de Minas e Energia da Câmara dos Deputados, o Dr. BOLÍVAR DE MOURA ROCHA assim se manifestou sobre a questão, enfatizando justamente as mútuas implicações entre a política de concorrência e as demais políticas de interesse do Estado: "A própria lei brasileira de defesa da concorrência contempla situações em que, diante do interesse público relevante, aquilo que seria inadmissível em circunstâncias normais do ponto de vista concorrencial passa a ser admissível, e até desejável, sob circunstâncias excepcionais. A alternativa aqui, diante da escassez de recursos fiscais para proceder ao enxugamento total desse mercado, seria advogar e insistir numa postura purista do ponto de vista concorrencial, e permitir que se instalasse a bancarrota nesse sistema produtivo. Nós estamos diante da exceção prevista na nossa lei, no que aliás ela não é exceção à prática de outros países. Ou seja, essa organização dos produtores para comercializar em bloco sua produção é não apenas tolerável, mas absolutamente desejável, do ponto de vista do interesse público, nesse momento. O Ministério do Desenvolvimento vai dizer isso formalmente aos órgãos que têm a atribuição de decidir sobre a admissibilidade da BBA, do ponto de vista concorrencial: o MF, o MJ, e em última instância o CADE. Vou sustentar isso com a tranqüilidade de quem durante muito tempo esteve à frente da área do Ministério da Fazenda responsável pela defesa da concorrência, que é a Secretaria de Acompanhamento Econômico. (fls. 472). “... A política do governo para o Programa do Álcool é uma política energética e ambiental. No entanto ela é nesse momento, antes de tudo e mais que tudo, uma política pelo emprego. Não estamos empenhados 
No julgamento da questão, considerou-se que o ato de concentração não atendia às condicionantes impostas no $\S 2^{\circ}$ do artigo 54 para a autorização do ato de concentração tendo em vista o "motivo de preponderante interesse nacional" (quais sejam, o aumento da produtividade, a melhoria da qualidade, o aumento da eficiência e do desenvolvimento tecnológico e a melhoria das condições dos consumidores). Dessa forma, por unanimidade o plenário do Conselho determinou a desconstituição do ato. A única divergência deveu-se à discussão sobre a abertura de processo administrativo para que se averiguasse a conduta da Brasil-Álcool S.A..

Com efeito, o voto do Conselheiro CELSO FERNANDES CAMPILONGO discutiu longamente se o ato perpetrado pelas requerentes poderia ser considerado um ato infrativo à concorrência. Ao entender que era necessária a investigação por meio de processo administrativo, afirmou: "Em resumo: há indícios de que o BA e a BBA limitaram e prejudicaram a livre concorrência (art. 20, I). A formação do suposto "cartel de crise" dá indicações de que se tentou a dominação de mercado (art. 20, II) e o aumento arbitrário de lucros (art. 20, III). Também existem vestígios de exercício abusivo de posição dominante, quer pelo percentual de mercado relevante controlado pelas Requerentes quer pela forma de organização dos interesses, com sinais de ofensa ao art. 20, IV, da Lei 8884/94. Além disso, o expresso acordo entre concorrentes, inclusive quanto a preços e condições de venda, tem toda a aparência de caracterizar tanto conduta comercial uniforme (art. 21, I e II) quanto pretensão de regular o mercado para limitar ou controlar a produção e a distribuição de bens (art. 21, X). Todos esses indicativos comportam investigação em processo administrativo" ${ }^{416}$.

Assim, no julgamento do caso mais emblemático de acordo de concorrentes o Conselho Administrativo de Defesa Econômica realizou uma extensa análise da viabilidade de ser aceito um ato de concentração que teria o condão de prejudicar a livre

principalmente em resgatar a saúde do produtor de álcool, embora esse seja também o nosso objetivo. Estamos empenhados em assegurar a solidez e a saúde da cadeia da agroindústria canavieira, e com ela o emprego no campo. Provavelmente isso exigirá da nossa parte dar alguns passos atrás no que diz respeito à desregulamentação que esse setor vem conhecendo. Pois bem, nós estamos dispostos a dar esses passos atrás". “... O Ministério tem muito claro que Programa do Álcool é para o Brasil sinônimo de desenvolvimento, e nós não vamos fugir dessa responsabilidade. Digo isso sem medo de incorrer em retórica fácil, porque o faço, olhando para trás, amparado na credibilidade decorrente de vários meses de trabalho intenso, duro e dedicado para "costurar", a quatro mãos com o setor privado, aquilo que é uma trilha de saída da crise e construção da solidez do Programa a médio e longo prazo" (fls. 473)".

416 Voto-vista do Conselheiro CELSO FERNANDES CAMPILONGO nos autos do Ato de Concentração nº 08012.004117/99-50. 
concorrência, tendo decido, ao final pela impossibilidade de sua realização. Sublinhe-se, entretanto, dois importantes aspectos: i) a operação foi estudada à luz do artigo 54 da lei concorrencial, ou seja, sob o manto do controle de estruturas, que entendemos ser mais adequado para analisar questões envolvendo possíveis eficiências e benefícios advindo de um cartel; ii) os objetivos da criação do Brasil-Álcool e as suas possíveis eficiências foram longamente discutidos pelo Conselho antes de proferir a sua decisão.

\subsection{Conclusão preliminar}

Conforme se examinou ao longo do Capítulo anterior, não encontramos incongruência entre a utilização dos cartéis de exportação e o quanto disposto no texto da Magna Carta. Muito ao contrário, acreditamos que muitos dos princípios estabelecidos para a ordem econômica estejam em perfeita consonância com a utilização do instrumento.

Tendo em vista a análise ora empreendida dos dispositivos da legislação concorrencial brasileira, resta claro que:

i) deve haver uma primeira decisão sobre a aplicação ou não do direito concorrencial aos cartéis de exportação. Em caso positivo, deveríamos ainda decidir se esta seria aplicável apenas aos cartéis de exportação do tipo misto ou também aos do tipo puro;

ii) em caso de optar-se pela aplicação, verificamos algumas formas de "adequar" as leis concorrenciais ao caso concreto, quais sejam: a rule of reason, as isenções, as autorizações e o emprego de termos fluidos;

iii) ainda dentro das opções de que dispõe a autoridade antitruste na análise dos cartéis de exportação, é de se verificar se será empregado o controle de condutas ou o controle de estruturas.

No resumo de PAULA A. FORGIONI: “O incentivo aos cartéis de exportação pode ser atuado i) pela não aplicação da lei Antitruste, fazendo-se como se ela não existisse, ou ii) pela concessão de isenções ou autorizações, tanto em um quanto em outro caso, justifica-se a colaboração governamental no fato de que os efeitos do cartel de exportação 
não são sentidos no mercado interno, mas acabam por afetar estruturas e consumidores estrangeiros, não protegidos pela lei Antitruste nacional"417.

417 Os fundamentos do Antitruste, cit., p. 416. 


\section{CONCLUSÃO}

Esta dissertação pretendeu examinar a possibilidade de utilização dos cartéis de exportação no ordenamento jurídico brasileiro. A conclusão a que podemos chegar é a de que eles podem sim ser usados, tendo em vista principalmente dois aspectos. O primeiro é o texto da Constituição de 1988 que estabelece em seu artigo $3^{\circ}$ objetivos a serem alcançados pela República Federativa do Brasil. De uma leitura pormenorizada de seus incisos é possível se inferir que os cartéis de exportação estão em linha especialmente com a garantia do desenvolvimento nacional e com a erradicação da pobreza. Da análise sistemática do artigo 170 da Constituição surgem outras considerações favoráveis às associações para exportação, especialmente as relacionadas à soberania nacional, à redução das igualdades regionais e sociais e a busca pelo pleno emprego.

O segundo aspecto é a redação da Lei 8884/94, que não deixa dúvidas quanto à possibilidade de a autoridade concorrencial autorizar atos de concentração que possam prejudicar a livre concorrência, desde que atendidos alguns critérios estabelecidos na lei. Foi ainda discutida a possibilidade de os cartéis de exportação serem autorizados mediante a concessão de isenções e de autorizações pelas autoridades competentes, a exemplo do que ocorre na União Européia. Outro importante ponto sobre o qual não podemos descurar é aquele sobre os limites territoriais para a lei concorrencial. Ela é aplicável unicamente aos atos que tenham reflexo no território nacional ou também deve ser utilizada para a disciplina de atos que não são por aqui sentidos? Caso adotemos a primeira forma de interpretação, as associações para exportação do tipo pura não seriam sequer objeto da disciplina de nossa lei concorrencial, entendimento esse que é adotado por inúmeros países do globo (as chamadas isenções implícitas).

Esses são os aspectos internos da discussão. No aspecto externo, discutimos as principais Escolas ideológicas que pretendem interpretar o direito concorrencial. Desse exame, pudemos chegar à conclusão de que a Escola de Chicago possui marcada influência sobre o direito concorrencial dos dias atuais, sendo a eficiência econômica o norte seguido pelos seus doutrinadores. Outra característica dessa Escola é a crença de que o Estado deve agir minimamente na economia, unicamente no sentido de corrigir eventuais falhas de mercado. Em oposição a esse entendimento trouxemos o daqueles pensadores que 
conferem ao direito antitruste um leque mais abrangente de objetivos, que se inserem dentro da política pública desenhada pelos países. Essa forma de encarar a disciplina permite maior mobilidade às autoridades no momento em que aplicam o direito, não estando limitadas à busca de eficiências estáticas, mas podendo procurar pelas dinâmicas, que supomos mais adequadas a países em desenvolvimento como o Brasil ${ }^{418}$.

Ademais, a utilização isolada de qualquer ramo do direito e uma busca desmedida pela eficiência econômica não parecem estar em linha com o nosso ordenamento jurídico e, especialmente, com o atingimento dos objetivos fundamentais traçados pelo constituinte. Como observamos ao longo do estudo, o direito concorrencial deve ser adequado ao nível de desenvolvimento dos países, cuidando das particularidades inerentes a cada um e não deve resultar de uma imposição externa, formulada tendo em vista realidades bastante diversas. Trazendo essas considerações para o tema desse trabalho, acreditamos que, a despeito de os cartéis de exportação poderem não resultar na melhor alocação possível dos recursos no mercado, e de eventualmente serem considerados como ingerências indevidas do Estado na economia, eles podem ser autorizados tendo em vista o atingimento de outros fins traçados politicamente.

Um outro ponto para o qual se deve chamar a atenção é o de que as tentativas para uniformização das regras concorrenciais, a que chamamos genericamente de "política internacional da concorrência" podem ser formas perigosas de retirar dos Estados parte da autonomia que hoje possuem (ou deveriam possuir) para a aplicação de seu direito antitruste. Observamos que a tendência é a de que a padronização seja feita levando em conta os preceitos das escolas clássicas e da Escola de Chicago, ou seja, tendo como fundamento a não intervenção do Estado na economia. $\mathrm{O}$ que se pretende, como bem lembrou AJIT SINGH, é a construção pelo mundo de "legal playing fields", nos quais se procurará que a concorrência atinja o seu nível máximo, o que, certamente, só beneficiará

418 "O pressuposto, mais do que a conclusão básica deste trabalho é o de que o desenvolvimento econômico e, mais amplamente, o desenvolvimento humano, só começa a se realizar quando um povo ou um conjunto de povos, no quadro da Revolução Capitalista, se transforma em uma Nação, logra se dotar de um Estado, e passa a deliberadamente buscar a melhoria dos padrões de vida. De acordo com essa perspectiva, o agente histórico por excelência do desenvolvimento econômico é a Nação - é a sociedade nacional que, compartilhando um destino comum, logra controlar um território e se dotar de um Estado que lhe sirva de principal instrumento de ação coletiva. A condição principal a determinar o bom êxito do desenvolvimento econômico é que essa Nação tenha autonomia e coesão suficientes para, por meio do seu Estado, formular uma estratégia nacional de desenvolvimento ou de competição econômica com as demais nações. Histórica ou empiricamente não há caso de verdadeiro desenvolvimento econômico sobre condição colonial" (LUIZ CARLOS BRESSER-PEREIRA, Desenvolvimento econômico e revolução capitalista, cit., p. 2). 
as transnacionais com sede nos países desenvolvidos. Ou seja, a competição será injusta com as empresa originárias dos países em desenvolvimento e somente trará proveito para os países centrais.

Ao adotarem esse tipo de política, os países em desenvolvimento aceitarão abrir a mão de instrumentos que poderiam ser úteis na condução de um processo sustentável de desenvolvimento, como é o caso dos cartéis de exportação.

Certamente, Não foi objetivo do trabalho fornecer incentivo desarrazoado à utilização dos cartéis de exportação. O que se propõe é unicamente a possibilidade de utilização desse ferramental para a implementação de políticas públicas, conforme já ocorre em outros países. Conforme demonstrado, essa possibilidade está de acordo com os princípios consagrados pela Constituição Federal em seus artigos 3. e 170. Necessária agora é a discussão sobre a conveniência e oportunidade desse uso.

Encerramos a análise com frase de EROS ROBERTO GRAU, que parece sumariar o quando estudado até aqui: "Tudo isso autoriza a conclusão de que afirmar a soberania econômica nacional como instrumento para a realização do fim de assegurar a todos existência digna e como objetivo particular a ser alcançado é definir políticas públicas voltadas à viabilização da participação da sociedade nacional, em condições de igualdade, no mercado internacional. Ao contrário do que se tem sustentando, pois, essa afirmação conduz não ao isolamento econômico, porém precisamente àquela viabilização" 419 .

419 EROS ROBERTO GRAU, op. cit., p. 30 e ss. 


\section{BIBLIOGRAFIA}

ADHIKARI, Ratnakar. In defence of export cartels. Disponível em: http://www.sawtee.org/uploads/articles/in9july04.php. Acesso em: 15 set. 2008.

ALFORD, Roger, The extraterritorial application of antitrust laws: The United States and the European Community approaches, Virginia Journal of International Law, v, 33, n. 1, 1992.

ALMEIDA FILHO, Niemeyer. O desenvolvimento da América Latina na perspectiva da Cepal dos anos 90: correção de rumos ou mudança de concepção? Disponível em http://www.ie.ufrj.br/prebisch/pdfs/12.pdf. Acesso em: 20 out. 2009.

AREEDA, Phillip; KAPLOW, Louis. Antitrust analysis, problems, text, cases. 4. ed. Boston: Little Brown \& Co., 1988.

- Antitrust analysis, problems, text, cases. 4. ed.

Boston: Little Brown \& Co., 1994. Supplement.

ASCARELLI, Tullio. Corso di diritto commerciale: introduzione e teoria dell'impresa. Milano: Giuffrè, 1962.

Ensaios e Pareceres, São Paulo, Saraiva, 1952.

AZEVEDO, Erasmo Valladão; FRANÇA, Novaes (org.). As associações e o novo Código Civil. São Paulo: Quartier Latin, 2009.

BASILE, Juliano. Autoridades dos EUA e da Europa ajudam Brasil a combater cartéis. Valor Econômico, 13 out. 2009. Disponível em: http://www.valoronline.com.br/?impresso/brasil/89/5865163/autoridades-dos-eua-e-daeuropa-ajudam-brasil-a-combater-carteis.

BECKER, Florian. The case of export cartel exemptions: between competition and protectionism, Journal of Competition Law and Economics, 3 (1), p. 97-126.

BERCOVICI, Gilberto. A Constituição de 1988 e o desenvolvimento regional do Brasil, Revista Brasileira de Estudos Constitucionais, v. 8, 2008, p. 37-54. 
. Constituição e política: uma relação difícil, Revista Lua Nova, n. 61,

São Paulo, 2004, p.5-24.

. O estado de exceção econômico e a periferia do capitalismo, Pensar, v.

11, Fortaleza, fev. 2006, p. 95-99.

BHATTACHARJEA, Aditya. Export cartels, a developing country perspective. Working

Paper n. 120. Center for Development Economics (CDE), Department of Economics, Delhi School of Economics, 2004.

Trade and Competition Policy. Working Paper n. 146, Indian Council for Research on International Economic Relations, 2004.

BIELSCHOWSKY, Ricardo. Formação Econômica do Brasil: uma obra-prima do estruturalismo cepalino, Revista de Economia Política. Disponível em http://www.rep.org.br/pdf/36-3.pdf. Acesso em: 13 ago. 2009.

; MUSSI, Carlos (coords.). Políticas para a retomada do crescimento reflexões de economistas brasileiros, Brasília, Escritório da CEPAL no Brasil, 2002

BLANCHARD, Olivier. Macroeconomia. 2. ed. Rio de Janeiro: Campus, 2001.

BORK, Robert H. The antitrust paradox. New York: Basic Books, 1973.

BRAUDEL, Fernand. Civilização material, economia e capitalismo - séculos XV-XVIII os jogos das trocas. São Paulo: Martins Fontes, 1998.

O tempo do mundo. São Paulo: Martins Fontes, 1998.

BRESSER-PEREIRA, Luiz Carlos. Desenvolvimento econômico e revolução capitalista. Texto para discussão EESP/FGV 170, out. 2008.

O novo desenvolvimentismo e a ortodoxia convencional. São Paulo em Perspectiva, São Paulo, Fundação Seade, v. 20, n. 3, p. 5-24, jul.-set. 2006. Disponível em: www.seade.gov.br. Acesso em: 26 ago. 2009.

BULGARELLI, Waldirio. Concentração de empresas e direito antitruste. 2 ed. São Paulo: Atlas, 1996. 
CARDOSO JR, José Celso (coord.). A constituição brasileira de 1988 revisitada: recuperação histórica e desafios atuais das políticas públicas nas áreas econômica e social. Brasília: IPEA, 2009.

CARVALHO, Leonardo Arquimimo de. Direito Antitruste e Relações Internacionais, Curitiba: Juruá, 2001.

CARVALHO, Vinicius Marques; SCHAPIRO, Mario Gomes. Política industrial e defesa da concorrência. Disponível em: http://www.cade.gov.br/news/n018/artigo.htm. Acesso em: 7 out. 2008 .

CASTRO, Ricardo Medeiros de. Antitruste e comércio internacional: tópicos de uma agenda de política externa. CADE Informa. Disponível em: http://www.cade.gov.br/news/n021. Acesso em: 15 out. 2009.

CHANG, Ha-Joon. Maus samaritanos: o mito do livre comércio e a história secreta do capitalismo. Rio de Janeiro: Elsevier, 2009.

COELHO, Fábio Ulhoa. Direito antitruste brasileiro. São Paulo: Saraiva, 1995.

COMPARATO, Fábio Konder. O indispensável Direito Econômico, Revista dos Tribunais, v. 353 (14), mar. 1965.

Muda Brasil: uma Constituição para o desenvolvimento democrático.

São Paulo: Brasiliense, 1986.

COSSOLINO, Silmara. Concorrência: momento é de amadurecimento, diz Coutinho. Gazeta Mercantil, 14 set. 2004.2 Disponível em: http://indexet.investimentosenoticias.com.br/arquivo/2004/09/14/198/CONCORRENCIAMomento-e-de-amadurecimento-diz-Coutinho.html. Acesso em: 27 maio 2009.

CRETELLA JÚNIOR, J. Comentários à Lei Antitruste. 2. ed. Rio de Janeiro: Forense, 1996.

- Livre iniciativa e direito concorrencial. In: COSTA, Marcos et al. (coord.). Direito concorrencial: aspectos jurídicos e econômicos. Rio de Janeiro: América Jurídica, 2002 
CUNHA, Ricardo Medeiros da. Antitruste e comércio internacional. CADE Inform. Disponível em: http://www.cade.gov.br/news/n021. Acesso em: 15 out. 2009.

DWORKIN, Ronald. Taking Rights Seriously, Cambridge: Harvard University Press, 1977.

FARINA, Elizabeth Maria Mercier Querido et al. Competitividade: mercado, estados e organizações. São Paulo: Singular/Fapesp, 1997.

FERRAZ JÚNIOR, Tercio Sampaio. Introdução ao estudo do direito: técnica, decisão, dominação. 2. ed. São Paulo: Atlas, 1994.

FERREIRA FILHO, Manoel Gonçalves. Comentários à Constituição brasileira de 1988. São Paulo: Saraiva, 1995. v. 4.

FIEBIG, André R. The German Federal Cartel Office and the application of competition law in reunified Germany. 14 U. Pa. J. Int'l Bus. L. 373, 1993-1994.

FIGUEIREDO, Fernando. As transformações do pós-guerra e o pensamento econômico da Cepal. Revista de Economia Política, v. 10, n. 4 (40), out.-dez. 1990.

FONSECA, João Bosco Leopoldino da. Lei de Proteção da Concorrência: comentários à Lei Antitruste. Rio de Janeiro: Forense, 1995.

FONSECA, José Marcelo Martins. Concentração empresarial e direito da concorrência. São Paulo: Saraiva, 2001.

FORGIONI, Paula A. A evolução do Direito Comercial brasileiro: Da mercancia ao mercado. São Paulo: Ed. RT, 2009.

A interpretação dos negócios empresariais no novo Código Civil brasileiro. Revista de Direito Mercantil, Industrial, Econômico e Financeiro, São Paulo, Malheiros, n. 130, ano XIII, p. 7-38, abr.-jun. 2003.

. Análise Econômica do Direito (AED): paranóia ou mistificação? Revista de Direito Mercantil, Industrial, Econômico e Financeiro, São Paulo, Malheiros, n. 139, p. 242-256, jul.-set. 2005.

Os fundamentos do antitruste. 3. ed. São Paulo: Ed. RT, 2008. 
FOX, Eleonor M. World antitrust and market Access, The American Journal of International Law, v. 91, n. 1, jan., 1997, p. 1-25.

FRIEDLANDER, David; TEREZA, Irany. BNDES gasta R $\$ 8$ bi em um ano para criar “campeões nacionais”. O Estado de S. Paulo, 27 set. 2009, p. B1.

FRIEDMAN, Thomas L. The great disruption. The New York Times. Disponível em: http://www.nytimes.com/2009/03/08/opinion/08iht-edfriedman.1.20672274.html?_r=1

\&pagewanted=print. Acesso em: 18 jun.2009.

FRITZ, Thomas. The wrong forum: competition policy in the WTO. Disponível em: http://www.blue21.de/PDF/S2B-Competition-Policy.pdf. Acesso em: 10 out. 2008.

FURTADO, Celso. A fantasia organizada. Rio de Janeiro: Paz e Terra, 1985.

GAZZONI, Marina. BNDES liberou R $\$ 18$ bilhões com juro reduzido para financiar bens de capital. Último Segundo. Disponível em: http://ultimosegundo.ig.com.br/economia/2009/12/04/bndes+liberou+r+18+bilhoes+com+j uro+reduzido+para+financiar+bens+de+capital+9194956.html. Acesso em 4 dez. 2009.

GILBERT, Milton. Export prices and export cartels. New York: AMS Press, 1971.

GOLDBERG, Daniel. Poder de compra e política antitruste. São Paulo: Singular, 2006.

GRAU, Eros Roberto. A ordem econômica na Constituição de 1988. 6. ed. São Paulo: Malheiros, 2000.

Elementos de direito econômico. São Paulo: RT.

HAIDAR, Rodrigo. Na crise, é preciso recrudecer política antitruste. Entrevista do presidente do CADE Arthur Badin, concedida ao portal Consultor Jurídico, em 28 de maio de 2009.2 Disponível em: http://www.cade.gov.br/Default.aspx?fa4edc2cc55bb17185b286da75. Acesso em: 18 jun. 2009.

IMMENGA, Ulrich. Export cartels and voluntary export restraints between trade and competition policy. HeinOnline, 4 Pac. Rim L. Pol'y J. 93, 1995. 
INTERNATIONAL COMPETITION NETWORK, Defining hard core cartels conduct, ICN. 4 th Annual Conference, Bonn, 6-8 jun. 2005.

IRTI, Natalino. L'ordine giuridico del mercato. 3 ed. Roma: Laterza, 1998.

JACQUEMIN, Alexis; NAMBU, Tsuruhiki; DEWEZ, Isabelle. A dynamic analysis of export cartels: the Japanese case. The Economic Journal, v. 91, n. 363, p. 685-696, Sept. 1981.

JOHANSEN, Erik. I say antitrust; you say anticompetitive: why bridging the devise between U.S. and E.U. competition policy makes economic sense. HeinOnline, 24 Penn St. Int'l L. Rev. 331, 2005-2006.

KHEMANI, Shyan (org.). Diretrizes para elaboração e implementação de política de defesa da concorrência. São Paulo: Singular, 2003.

KUPFER, David; HASENCLEVER, Lia. Economia Industrial - Fundamentos Teóricos e Práticas no Brasil, São Paulo: Editora Campus, 2002.

KURLANSKY, Mark. Sal - uma história do mundo. São Paulo: Senac, 2004.

LATTES, Alessandro. Il diritto commerciale nella legislazione statutaria delle città italiane. Milano: Ulrico-Hoepli, 1884.

LEVENSTEIN, Margaret C.; SUSLOW, Valerie Y. The changing international status of export cartel exemptions. 20 Am. U. Int'l L. Rev., p. 785-828, 2004-2005.

MAGNUS, John R. Joint export trade provisions in antitrust laws: a supporter's perspective. Journal of World Trade, 39 (1), p. 181-184, 2005.

MANKIW, N. Gregory. Introdução à economia. 3. ed. São Paulo: Cengage Learning, 2008 .

MANTEGA, Guido. 'A fantasia organizada': uma crônica intervencionista. Revista de Economia Política, v. 6, n. 1, p. 143, jan.-abr. 1986.

MARTELLO, Alexandro. Governo vai abrir linha de crédito de R \$ 80 bilhões para o BNDES, diz Mantega. G1. Disponível em: http://g1.globo.com/Noticias/Economia_Negocios/0,,MUL1408791-9356,00- 
GOVERNO+VAI+ABRIR+LINHA+DE+CREDITO+DE+R+BILHOES+PARA+O+BND ES+DIZ+MANTEGA.html. Acesso em: 9 dez. 2009.

MARTINS, Ives Gandra da Silva; REZEK, Francisco (coords.), Constituição Federal, Avanços, contribuições e modificações do processo democrático brasileiro, São Paulo, RT, 2008

MATTOS, César. Harmonização das políticas de defesa da concorrência e comercial: questões teóricas e implicações para o Mercosul, Alca e OMC. Est. Econ., São Paulo, v. 29, n. 2, p. 267-291, abr.-jun. 1999.

MURPHY, Daniel T. The Export Trade Association Act of 1981 - a brief analysis. 4 Hastings Int'l \& Comp. L. Rev. 399, 1980-1981.

NUNES, António José Avelãs. Uma introdução à economia política. São Paulo: Quartier Latin, 2007.

NUSDEO, Ana Maria de Oliveira. Defesa da concorrência e globalização econômica - o controle da concentração de empresas. São Paulo: Malheiros, 2002.

NUSDEO, Fábio. A ordem econômica constitucional no Brasil. Revista de Direito Mercantil, Industrial, Econômico e Financeiro,São Paulo, Malheiros, n. 65, p. 12-20, jan.mar. 1987. . Fundamentos para uma codificação do Direito Econômico, São Paulo: RT, 1995. . Regulação e desenvolvimento. São Paulo: Malheiros, 2002. . Enciclopédia Saraiva de Direito. São Paulo: Saraiva, v. 2.

O ESTADO DE S. PAULO, 15 set. 2009, B4.

OECD. Export cartels, report of the committee of experts on restrictive business practices. Paris, 1974. . Obstacles to Trade and Competition, Paris, 1993. 
OLIVEIRA, Gesner de. Concorrência: panorama no Brasil e no mundo. São Paulo: Saraiva.

PAVIC, Vladimir S. J. D. Extraterritoriality in the matters of antitrust. Fucecchio (Itália): European Press Academic Publishing, 2001.

PETTER, Lafayete Josué. Princípios Constitucionais da Ordem Econômica, São Paulo: RT, 2005.

PINDYCK, Robert; RUBINFELD, Daniel. Microeconomia. 4. ed. São Paulo: Makron Books, 1999.

PROENÇA, José Marcelo Martins. Concentração empresarial e direito da concorrência. São Paulo: Saraiva, 2001.

. Direito concorrencial: aspectos jurídicos e econômicos. São Paulo: América Jurídica, 2003.

REICH, Arie. The agricultural exemption in antitrust law: a comparative look at the political economy of market regulation. HeinOnline, 42, Tex. Int'l L.J. 848, p. 843-874, 2006-2007 (Texas International Law Journal, v. 42, p. 843).

REYNOLDS, Lloyd G. The American Economic Review, v. 30, n. 4, p. 736-747, dez. 1940.

ROSENTHAL, Douglas. Chief of foreign commerce section. 49 Antitrust Law Journal 1189, p. 1189-1196, 1980.

SALOMÃO FILHO, Calixto. Direito concorrencial - as condutas. São Paulo: Malheiros, 2003.

. Direito concorrencial - as estruturas. 3 ed. São Paulo: Malheiros, 2002.

. Regulação da atividade econômica. São Paulo: Malheiros, 2001.

. (coord). Regulação e desenvolvimento. São Paulo: Malheiros, 2002. 
SCHWALBACH, Joachim; SCHWERK, Anja. Stability of German cartels. HumboldtUniversität zu Berlin / Wirtschaftswissenschaftliche Fakultät / Institut für Management. abr. 1998. Disponível em: http://www2.wiwi.hu-berlin.de/institute/im/publikd1/98-2.pdf.

SHIEBER, Benjamin M. Abusos do poder econômico: direito e experiência antitruste no Brasil e nos EUA. São Paulo: Ed. RT, 1966.

SILVA, José Afonso da. Comentário contextual à Constituição. 3 ed. São Paulo: Malheiros, 2007.

. Curso de direito constitucional positivo. 16. ed. São Paulo: Malheiros, 1999.

SILVA NETO, Manoel Jorge e. Direito constitucional econômico. São Paulo, LTr, 2001.

SINGH, Ajit. Competition and competition policy in emerging markets: international and developmental dimensions. G-24 Discussions Paper Series, Center for International Development Harvard University, n. 18, Sept. 2002.

Multilateral competition policy and development: a developing country perspective on the European Community proposals (2003). Disponível em: www.ideaswebsite.org/feathm/aug2003/MCP.pdf.

; DHUMALE, Rahul. Competition Policy, development and developing countries, Trade-Related Agenda, Development and Equity Working paper, South Centre, nov., 1999.

; WOLFSON, Leandro. Asia y América Latina comparados: divergencias económicas en los años '80. Desarrollo Económico, v. 34, n. 136, p. 513-532, jan.-mar. 1995.

SLACK, Nigel; CHAMBERS, Stuart; JOHNSTON, Robert. Administração da produção. São Paulo: Atlas, 1997.

SOKOL, D. Daniel. What do we really know about export cartels and what the appropriate solution. Legal Studies Research Paper, University of Florida, n. 2009, 05. 
SOUZA, Washington Peluso Albino de. A experiência brasileira de Constituição econômica. Revista Brasileira de Estudos Sociopolíticos, n. 67/68, jul. 1988 a jan. 1989.

SULLIVAN, E, Thomas; HOVEMKAMP, Herbert. Antitrust law, policy and procedure: cases, materials, problems, Charlottesvile: Lexis Law Publishing, 1999.

SWEENEY, Brendan J. Global competition: searching for a rational basis for global competition rules, 30 Sydney L. Rev. 209, 2008.

TELSER, L. Competition, colusion and game theory. Chicago: Aldine Atherton, 1972.

UESUGI, Akinori. How Japan is tackling enforcement activities against cartels. HeinOnline, 13 Geo. Mason L. Rev. 349, p. 349-365, 2004-2006.

VALLE, Alberto Salazar. Os desafios do crescimento durante o século XXI. Seminário realizado dias 6 e 7 de dezembro de 2004 na Universidade de Campinas. Disponível em: http://www.unicamp.br/unicamp/unicamp_hoje/ju/dezembro2004/ju276pag05.html.

Acesso em: 27 ago. 2009.

VAZ, Isabel. Direito econômico e concorrência: Rio de Janeiro: Forense, 1993.

VICTOR, A. Paul. Export cartels: an idea whose time has passed. 60 Antitrust Law Journal 571, p. 571-581, 1991-1992.

WALLER, Spencer Weber. The ambivalence of United States antitrust policy towards single-country export cartels, 10 Nw. J. Int'1 L. \& Bus. 98 1989-1990.

WASHINGTON TARIFF \& TRADE LETTER, de 8 ago. 2005.

WTO. Communication from India. WT/WGTCP/W/216, 26 Sept. 2002.

WTO. Communication from Japan. WT/WGTCP/W/156, 19 Dec. 2000.

WTO. Communication from Thailand. WT/WGTCP/W/213, 24 Sept. 2002.

WTO. Communication from the United States. WT/WGTCP/W/203, 15 Aug. 2002.

WTO. Exception, exemption and exclusion contained in members' national competition legislation. WT/WGTCP/W/172, 6 July 2001. 
WTO. Report on the meeting of 1-2 July 2002. WT/WGTCP/M/18, 20 Sept. 2002.

WTO. Report on the meeting of 20-21 Feb. 2003. WT/WGTCP/M/21, 26 May 2003.

WTO. Report on the meeting of 2-3 Oct. 2000. WT/WGTCP/M/92, 8 Nov. 2000.

WTO. Report on the meeting of 26-27 Sept. 2002. WT/WGTCP/M/19, 15 Nov. 2002.

YAMANE, Hiroko. Trade and competition in the Japanese experience. $2 \mathrm{~J}$. Int'l Econ. L, p. $537-545,1999$.

\section{Sites consultados:}

http://apps.fiesp.com.br/sbsnetv2/big/sindical-juridica/pdf/lexico_atual4.pdf. Acesso em: 20 nov. 2008.

http://biotech.law.lsu.edu/cases/Antitrust/Standard_Oil_case.htm. Acesso em: 17 out. 2009.

http://blog.planalto.gov.br/acordo-com-uniao-europeia-fortalece-combate-a-carteis-nobrasil/. Acesso em: 14 out. 2009.

http://br.invertia.com/noticias/noticia.aspx?idNoticia=200810301427_RTR_1225376175n N3066281\&idtel. Acesso em: 30 out. 2008.

http://caselaw.lp.findlaw.com/cgi-bin/getcase.pl?court=us\&vol=166\&invol=290. Acesso em: 17 out. 2009.

http://eur-lex.europa.eu/LexUriServ/LexUriServ.do?uri=OJ:C:2008:115:0001:01:PT:

HTML. Acesso em: 26 set. 2008.

http://g1.globo.com/Noticias/Economia_Negocios/0,,MUL1169476-9356,00.html, Acesso em: 22 jun. 2009.

http://www.abiotica.com.br/exibe_noticia.php?id_noticia=150. Acesso em: 20 ago. 2008. 
http://www.ftc.gov/bc/hsr/index.shtm. Acesso em: 10 set. 2008.

http://www.oecd.org/dataoecd/8/61/2376087.pdf. Acesso em: 20 out. 2009.

http://www.sawtee.org/uploads/articles/in9july04.php. Acesso em: 15 set. 2008.

http://www.u-s-history.com/pages/h956.html. Acesso em: 17 out. 2009.

www.ftc.gov.os/statutes/webbpomerene/index.shtm. Acesso em: 24 nov. 2008.

www.it.doc.gov/td/oetca/guidelines.html. Acesso em: 24 nov. 2008.

www.it.doc.gov/td/oetca/teamup.html. Acesso em: 24 nov. 2008.

www.oecd.org/dataoecd/8/61/2376087.pdf. Acesso em: 4 nov. 2008.

www.seae.fazenda.gov.br/central_documentos/glossarios/E. Acesso em: 24 nov. 2008. 


\section{RESUMO}

A presente dissertação objetiva verificar a possibilidade de utilização dos cartéis de exportação tendo em vista o ordenamento jurídico brasileiro. Para tanto, um importante corte metodológico foi realizado: somente questões relativas ao direito constitucional e ao direito concorrencial foram analisadas, deixando-se de lado aquelas que nos são trazidas pelo direito internacional e pela ciência econômica. O trabalho pode ser dividido em três grandes partes. A primeira cuida de justificar a escolha do tema "cartéis de exportação". Para tanto, nos valemos da idéia de que as exportações são importante instrumento do qual se valem os Estados para equilibrar a sua atividade econômica e fomentar/financiar o seu desenvolvimento.

A segunda parte cuida dos acordos entre concorrentes. Nesse passo, realizamos um pequeno estudo sobre as principais Escolas ideológicas que pretendem interpretar o direito antitruste e apontar a forma correta para a sua aplicação. Em seguida, cuidamos dos cartéis clássicos (os hard core cartels) e tratamos de diferenciá-los dos demais acordos entre concorrentes. É hora então de cuidarmos especificamente dos cartéis de exportação. Traremos as suas principais características, classificações e os benefícios e malefícios que são apontados pela doutrina. Bem definidos esses instrumentos, adentramos em um terreno bastante inóspito, que é o da forma pela qual os cartéis de exportação são encarados pelos Estados e pelas associações internacionais. Observaremos que, a despeito de serem utilizados por países como os Estados Unidos, existe uma tendência de que sejam tratados como condutas anticompetitivas, a semelhança dos cartéis clássicos. Uma das possíveis justificativas para isso seria a adoção generalizada dos conceitos da Escola de Chicago e das teorias econômicas neoclássicas. A principal crítica realizada por esses doutrinadores é a de que os cartéis de exportação são formas indevidas de atuação do Estado na economia que alteram as condições "naturais" de concorrência no mercado internacional.

A última parte dessa dissertação está voltada para a inserção de toda a discussão promovida na moldura que nos é trazida pela Constituição Federal de 1988 e pela lei Antitruste brasileira (Lei 8884/1994). Para o texto constitucional, nosso enfoque será principalmente o dos artigos $3^{\circ}$ (objetivos fundamentais da República Federativa do Brasil) e 170 (princípios gerais da atividade econômica). Com relação à lei antitruste, a discussão será voltada para a forma pela qual os cartéis de exportação são disciplinados por nossa lei. 


\begin{abstract}
The present essay aims to verify the possibility of using export cartels, considering the Brazilian Law system. For that, an important methodological cut has been done: only matters regarding constitutional law and anti-trust law have been analyzed, leaving apart those matters that are brought to us by the international law and economical science. It can be divided in three big parts. The first one handles the justification for the choice of the subject "export cartels". For that, we make use of the idea that the exportations are an important instrument for the Countries to balance their economical activity and stimulate/finance their development.
\end{abstract}

The second part deals with the agreements between competitors. At this pace, we made a small study about the main ideological stream, that intend to understand the antitrust law and identify the correct form for its application. Following that, we mention the classical cartels (the hard core cartels) and differentiate them from the other agreements between competitors. It is time then to handle the export cartels. We mention their main traits, classification, benefits and losses that are pointed by the doctrine. Being those instruments well defined, we enter and uninviting terrain, that is the way that the countries and International Associations face the export cartels. We observe that, despite being used by countries like United States, there is a tendency to treat it like uncompetitive behavior, resembling the classical cartels. One of the possible explanations for that would be the general adoption of the concepts brought by the Chicago stream and the neoclassical economical theories. The authors' main critic is that the export cartels are inappropriate methods of Government intervention in the Economy that alters the "natural" conditions of the competition in the international market.

The last part of such essay is dedicated to the insertion of all the discussion promoted in the patters that are brought to us by the Federal Constitution of 1988 and the Anti-trust Brazilian Law (Law 8884/1994). Regarding the constitutional text, our focus in mainly on the 3rd article (fundamental goals of the Brazilian Federal Republic), and the article 170 (general principles of the economical activity). Regarding the Anti-trust law, the discussion is facing the way that the export cartels are ruled by such area of our legal system. 